\title{
The Societal Influence on Individual Identity and the Relationship of Costume Design in Caryl Churchill's Cloud 9
}

\author{
Laura Kay Plikerd \\ West Virginia University, Ikp0003@mix.wvu.edu
}

Follow this and additional works at: https://researchrepository.wvu.edu/etd

Part of the Other Theatre and Performance Studies Commons

\section{Recommended Citation}

Plikerd, Laura Kay, "The Societal Influence on Individual Identity and the Relationship of Costume Design in Caryl Churchill's Cloud 9" (2020). Graduate Theses, Dissertations, and Problem Reports. 7913. https://researchrepository.wvu.edu/etd/7913

This Thesis is protected by copyright and/or related rights. It has been brought to you by the The Research Repository @ WVU with permission from the rights-holder(s). You are free to use this Thesis in any way that is permitted by the copyright and related rights legislation that applies to your use. For other uses you must obtain permission from the rights-holder(s) directly, unless additional rights are indicated by a Creative Commons license in the record and/ or on the work itself. This Thesis has been accepted for inclusion in WVU Graduate Theses, Dissertations, and Problem Reports collection by an authorized administrator of The Research Repository @ WVU. For more information, please contact researchrepository@mail.wvu.edu. 
The Societal Influence on Individual Identity and the Relationship of Costume Design in Caryl Churchill's Cloud 9

Laura Kay Plikerd

Follow this and additional works at: https://researchrepository.wvu.edu/etd

Part of the Other Theatre and Performance Studies Commons 


\title{
The Societal Influence on Individual Identity and the Relationship of Costume Design in Caryl Churchill's Cloud 9.
}

\author{
Laura Kay Plikerd \\ Thesis submitted \\ to College of Creative Arts \\ at West Virginia University \\ in partial fulfillment of the requirements for the degree of \\ Master of Fine Arts in \\ Design and Technical Theatre: Costume Design and Technology \\ Mary McClung, M.F.A., Chair \\ Radhica Ganapathy, Ph.D. \\ Tiffany Delligatti, M.F.A. \\ WVU School of Theatre \& Dance \\ Morgantown, West Virginia 2020
}

Keywords: Caryl Churchill, Cloud 9, Costume Design, Costumes, Society, Churchill

Copyright: Laura Plikerd 2020 


\section{ABSTRACT \\ The Societal Influence on Individual Identity and the Relationship of Costume Design in Caryl Churchill's Cloud 9.}

\section{Laura Kay Plikerd}

Cloud 9 is a play written by Caryl Churchill in 1978. Act one of the play takes place in 1870, British Occupied Africa and act two takes place in contemporary London. In our production, contemporary London was set in 2018. The dramatic shift in time during the two acts brings attention to the changing societal ideals and practices of each era. The costumes for this production of Cloud 9, illuminated the differences between the times by highlighting the stark differences in societally accepted fashion in the chosen time periods and regions.

In Cloud 9, the costumes create a framework for the reality of the period of the show. The audience knows what time period the acts take place in through the shifts in fashion. I used historical garments, costume recreations of Victorian garments, and paintings for research in portraying British occupied Africa. For modern fashion, I used runway fashion and the social media site Instagram for inspiration.

After creating the initial costume designs, I worked in the costume shop to ensure the accurate representation of the costumes with the support of the shop staff and lab students. This included purchasing supplies and off the rack costume pieces, keeping track of the budget, organizing fittings with the shop and stage management, pulling costume pieces, and creating show paperwork. 


\section{Acknowledgments}

Thank you to my mother and father for their support through my academic journey. My sister for always being a rock when I needed to know where I stand and an ear when I needed someone to listen.

Thank you to everyone who worked on this production of Cloud 9. It takes a village to make a production successful and I am grateful for the talent, passion, and hours of time dedicated to this show. 
Table of Contents
Abstract.
Acknowledgments........................................................

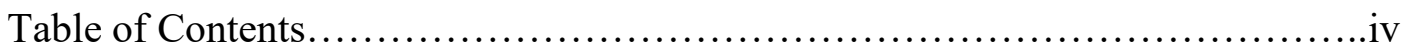
Introduction........................................................ $1-2$
Plot Story and Analysis.................................................. $3-7$

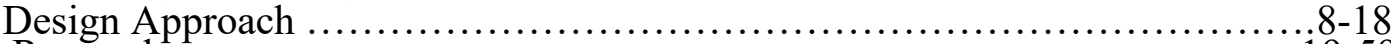
Research.............................................................
Project Process ......................................................... 60-68
Execution of Costumes in Performance..................................69-74
Evaluation and Conclusion............................................. $75-81$
Evaluation of the Play............................................. 82-84
Works Cited........................................................ 85-86

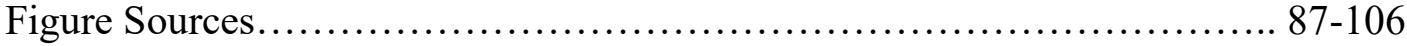
Appendix A: Additional Images.................................. 107- 112
Appendix B- "Look Books"........................................... 113-138
Appendix C- "Look Books" Research Images Works Cited................ 139-165
Appendix D: "Scene Breakdown".................................... 166-179
Appendix E: "Intermission Costume Changes".......................... 180-181 


\section{INTRODUCTION}

This thesis covers the process by which the costumes were brought to life for the West Virginia University 2018 production of Cloud 9. This includes a summary and analysis of Caryl Churchill's Cloud 9, the research that was the basis for the costume designs, the process of creating the final designs in the costume shop, the resulting production, and an evaluation of the process.

Cloud 9 was produced for the 2018 mainstage season at West Virginia University in the Gladys G. Davis Theatre. The Director for the show was Professor Radhica Ganapathy, with Scenic Design by Graduate student Lindsey Mariano, Lighting Design by Graduate student Thomas Gillette, Properties Design by Professor Robert Klingelhoefer, and Sound Design by Professor Alan McEwen. The Stage Manager for the show was an Undergraduate student named Joseph Vasquez. In the costume shop, Professor Tiffany Delligatti worked as the Draper and Graduates students Chloe Cappuccilli and Katy Ellenich assisted as Cutters and Stitchers.

Churchill's Cloud 9 is considered a postmodern theatre piece. Postmodernism is defined:

based on the idea that there is no Grand Narrative or Ultimate Truth. Most postmodern productions are centered around highlighting the fallibility of the "truths" which are held as definite, more precisely, Grand Narratives ("Truths") are deconstructed in order for the audience to reach their own individual understanding. Essentially, this process of deconstruction raises questions rather than attempting to supply answers. (Art and Culture)

Churchill challenges the social norms of gender identities and the linear nature of time by creating a jump of time between Act I and Act II. It is through the contrast in time and the choice 
to double cast characters in both acts that the audience is able to see how the pressures of societal influences have affected the characters' psyche and relationships. 


\section{PLOT STORY AND ANAYSIS}

This section breaks down the story of Cloud 9. It also begins to dissect the characters actions in the play and the topical issues Churchill is addressing through them. The play deals with issues such as sexism, gender roles, racism, sexual relationships, and Pedophilia.

Cloud 9 begins in the home of Clive, a British Colonial Administrator, who is stationed in Africa. Clive is in charge of overseeing the British territory in his region and keeping the local tribes in compliance. His wife, Betty, is struggling with being in Africa and maintaining the household when Clive is gone for various stretches of time. Churchill directs that the characters of Betty and her son Edward are cast as cross-gender roles while the character Joshua, their African servant is cast cross-racially and played by a white actor. By doing this Churchill highlights the role of colonial and sexual oppression faced by these characters. Appearing in Act I as well, is Betty's mother, Maud; Edwards's governess, Ellen; their neighbor, Mrs. Caroline Saunders; Betty and Clive's daughter, Victoria and a family friend, "explorer” Harry Bagley.

Betty’s femininity is considered a weakness by her husband, Clive. In the first scene of Act I, Clive references the fact that in the past Betty has been known to faint and have fits of hysteria. Clive casually addressing Betty's mental health in a derogatory manner only minutes into the play shows how Betty is only valued when she is able to live up to his highest expectations. When showing less than ideal emotions she is being a burden for Clive.

Joshua also struggles with his identity due to Clive's ownership over his life. While Joshua is a native to Africa, he is played by a white male actor. Joshua denounces his tribe and parental figures, claiming Clive as both his mother and father. Joshua is so indoctrinated by the colonist ideals he is subjected to, that he abandons his African identity to pursue an appearance that is better received by Clive, his master and ideal. 
Edward is also a character that is cross-gender cast, as he is a young boy played by a female actor. Edward is repeatedly belittled by the adult characters in the play for not being manly enough. He wishes to play with his sister's doll, something that is consistently looked down upon by all characters in the play as being an effeminate characteristic.

Edward's sister, Victoria, is played by a doll in Act I. As a doll she is moved across the stage by the other characters and has no agency of her own. She is a child who cannot voice her own needs. Not only does she not have a voice, but she is simply a doll to be played with by others. This reflects Clive's ideals of children being dutiful to their parents while also enforcing the ideal of female characters being beautiful, but silent.

Throughout Act I, Betty, Joshua and Edward struggle with their power dynamics within Clive's household. Betty, being Clive's wife, tries to assert her authority over Joshua. When they are alone he is less than receptive to her attempts to be in control and refuses to listen to her commands. Only when other male figures come to her aid does Joshua acknowledge Betty's authority. In return Joshua spies on Betty and reports her indiscretions to Clive in order to gain Clive's favor. Similarly, Joshua is also only receptive to Edward at specific moments. For instance, when Edward takes on a traditional male role he asserts authority over Joshua by playing the part of "young master" and ordering him around. In this moment Joshua respects Edward. Yet when Edward chooses to act more in line with feminine traits and is seen to be playing with Victoria's doll, Joshua rips open the doll and throws it to the ground. Churchill lets the audience know that respect is achieved in the Act I by falling in line with the normative roles of race, gender, and sexuality as prescribed by Victorian society.

While there are social conflicts between the family members in Clive's home due to the characters not fitting into their prescribed roles, there is external conflict created by the introduction of Mrs. Caroline Saunders, a British neighbor in Africa, and Harry Bagley, a British explorer and Clive's friend. The fear of her household staff attacking her prompts the character 
Mrs. Saunders to flee her house in the night to seek shelter at Clive's home. The introductions of these characters heighten the conflict within Clive's household with the introduction of infidelity between multiple characters. Clive pursues a physical relationship with Mrs. Saunders while Betty wishes to run off and have an adventurous affair with Harry Bagley, who is also having sex with Joshua and grooming Edward. "Grooming" is a "method used by offenders that involves building trust with a child and the adults around a child in an effort to gain access to and time alone with her/him" (Pollack).

The characters' struggle to uphold strict traditional Victorian ideals in the isolation of the African environment. Women of the era were expected to be virtuous and to primarily care for the home while the men were expected to financially provide for their family and not display the frivolous emotions considered to be feminine traits. Also, homosexuality was illegal at this time in England. Each character finds themselves struggling to uphold different ideals. Clive and Betty have extramarital affairs. Harry Bagley isolates himself from English society in order to be able to explore his sexuality. Another example provided by Churchill is Ellen, the household governess, has feelings for Betty yet whenever she chooses to voice her feelings Betty shoots her down claiming Ellen is confused or just lonely.

In addition to the character's sexual struggles, there is also the weight of the prescribed gender roles that adds to the tension within the household. Betty strives to be the perfect wife while wishing to run away with Harry Bagley. There are multiple instances where Edward wishes to play with a female doll and is repeatedly chastised for displaying feminine qualities. Mrs. Saunders has a certain level of freedom allotted to her because of being a widower. She is able to take agency over her own life by running away from home with a gun, openly displaying her sexuality, and being an out-spoken character. This leads her to be an anomaly in the household, leading to the women openly despising her and Clive taking advantage of her sexually. 
Churchill adds tribal skirmishes in the area to act as an external conflict that affects the household. Racial tensions escalate and a village of African natives is slaughtered offstage by the British soldiers and this includes the parents of the household servant, Joshua. While Joshua claims to hate his tribe and love Clive like a father and mother, Clive's neglectful and insensitive nature eventually causes a rift in their relationship. Joshua ends up rebelling and the act ends with him aiming a gun at Clive.

Act II of Cloud 9 takes place in modern day, 2018 London. For the characters in the play, it has only been twenty-five years, but for the audience it has been one hundred and forty-eight years since the events of Act I. The external pressures that dictated the characters actions in Act I have changed in the modern setting of Act II. While there is some religious debate and pressure over sexuality, in general there is less social stigma over homosexuality. Female rights have also increased since the Victorian times. Women have the right to vote, own land, and work outside the home.

These factors come into play in Act II because the characters struggle more with personal conflicts and less with the pressures of society. Betty is divorcing Clive and dealing with the anxiety over being alone for the first time. Lin, a friend of Victoria's, is a lesbian and wishes to pursue a relationship with Victoria. In contrast to Lin, Edward is on the queer spectrum but does not wish to be openly exposed as gay. He has been in a relationship with a man named Gerry but it is also implied that he may be transgender. The character of Clive is not seen in modern times except as a shadow of his Victorian self at the end of Act II. While once the central family figure, Clive's family have rebelled against his authority making him an afterthought in their modern lives. The actor who plays Clive also plays Lin's daughter Cathy. Cathy is the embodiment of all the characteristics that Clive hated. She is female and while she wears dresses, she refuses to stay within gender norms and plays with guns; she is also a child that is loud and demanding. 
Churchill emphasizes sexual liberation in Act II of Cloud 9. This can be seen through the relationship between Lin and Victoria who pursue a polyamorous relationship with Edward and Martin. With Victoria and Edward being siblings, this relationship is incestual. Gerry openly cruises on trains and in the park looking for sexual encounters. Betty also has her own sexual awakening in the act with her rediscovering masturbation. 


\section{DESIGN APPROACH}

This section addresses my initial ideas while coming up with a design concept for the show. I was inspired by multiple art pieces that provided a jumping off point to discuss the visuals of Cloud 9 with the Director and other designers.

The design team for Cloud 9 was directed by Professor Radhica Ganapathy, with Scenic Design by graduate student Lindsey Mariano, Lighting Design by graduate student Thomas Gillette, Properties Design by Professor Robert Klingelhoefer, and Sound Design by Professor Alan McEwen. Our first meeting took place at the end of the 2017-2018 school year before everyone went away for the summer. There was initial discussion of having a lush, beautiful landscape for the scenic design with large flowers made of trash or unusual materials. Juxtaposition between the characters and their environment was emphasized in this meeting. It was also discussed that the time jump between the acts would be extended from the 100 years in Churchill's script. Act II would take place in modern day 2018, at this time we tentatively had Act II taking place in the United States something that would change later in the process as discussed in the research section.

To create conceptual ideas to communicate to the director, I tried to find art pieces that abstractly represented the feelings of both acts in order to have a general visual jumping off point for initial discussions of the piece. The first image that aligned itself with the conceptual approach was Figure 1 "A Space of Your Own" by Paul Richmond. While the colors were brighter than I imagined for Act I, the feeling of chaos or distortion and a person being at odds with their environment resonated for the characters of Cloud 9 who are adrift in a foreign land trying to hold onto their societal ideals while struggling with their individual desires. I adjusted the colors of the painting to tone down the energy and create a simpler color palette, seen in Figure 2. Another painting that represented Act I 
was Figure 3, the "Self Portrait 17" by Jakub Kujawa. Its forceful brushstrokes and

blended colors create visual turmoil that feels like a person struggling with their identity, which is a central theme in the act.

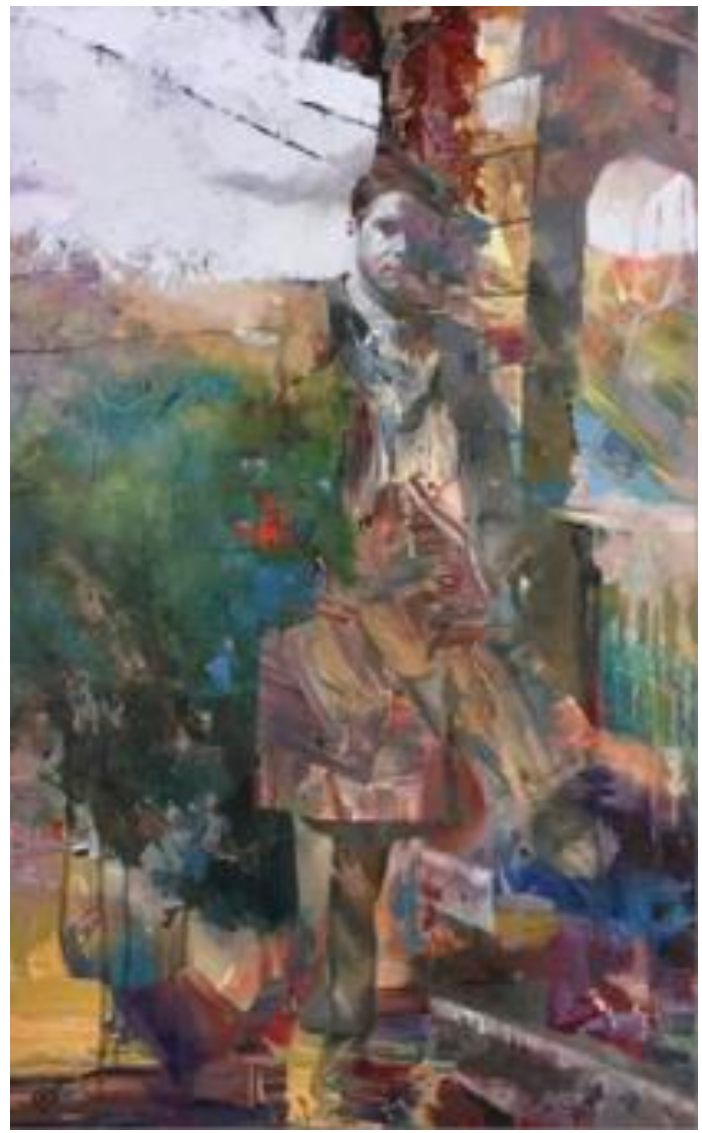

Figure 1:

A Space of Your Own by Paul

Richmond

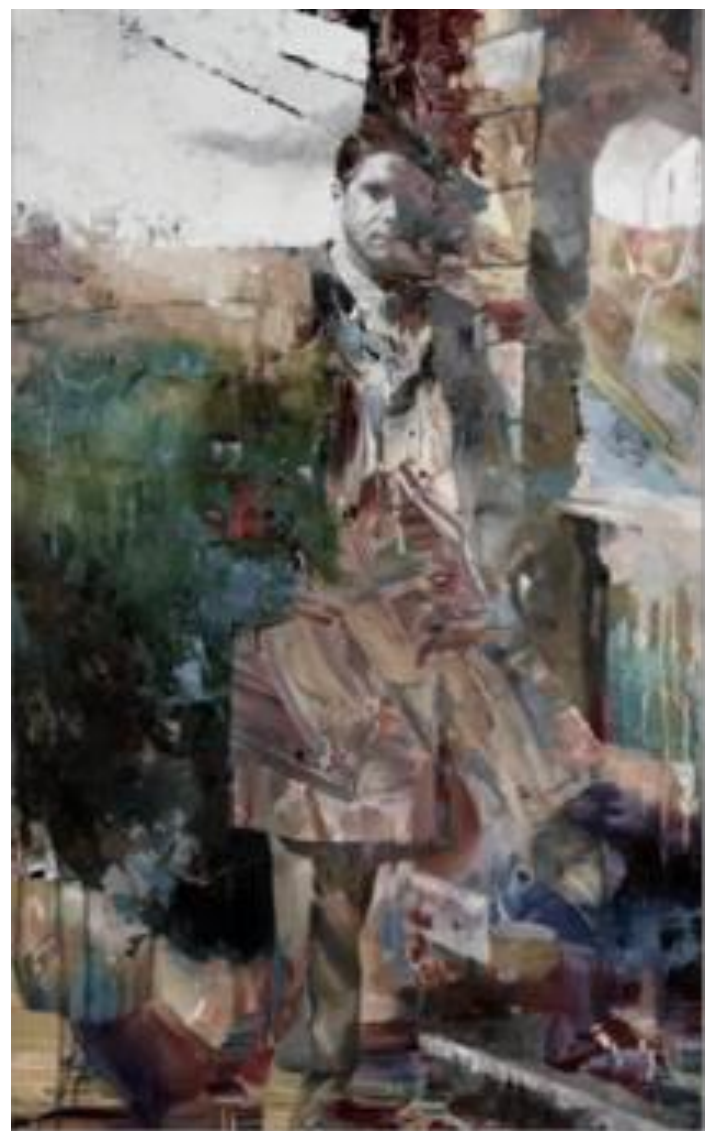

Figure 2:

A Space of Your Own by Paul Richmond- Toned Down Painting 


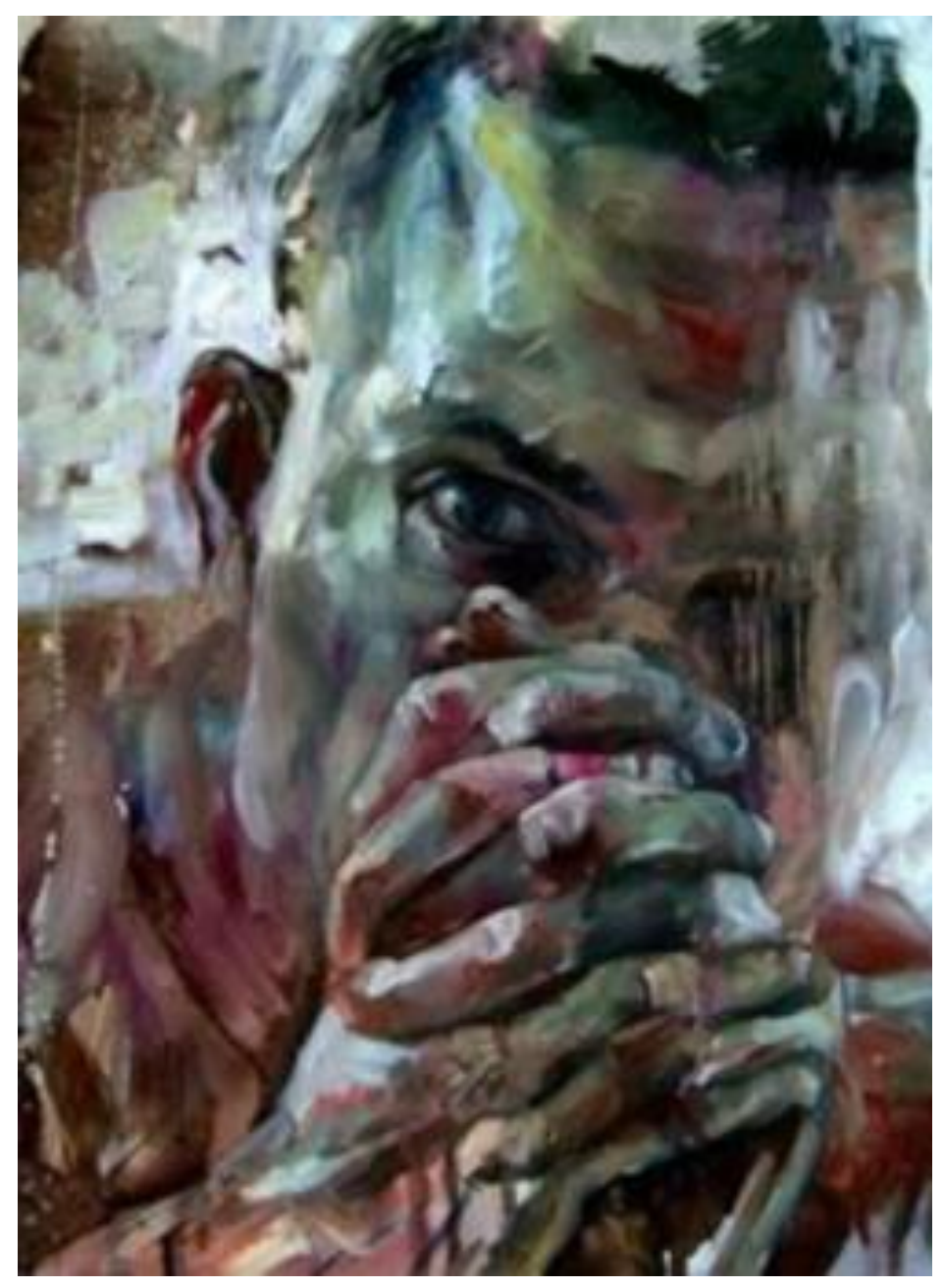

Figure 3: Self Portrait 17 by Jakub Kujawa

When looking for images to represent Act II of Cloud 9, I looked for paintings with brighter colors to contrast the more monotone values from Act I. I went this route in Act I because the characters are struggling to stay in accordance with the rules of decorum set by their Society's tradition; this need to fall in-line with expectations is embodied in the homogenous color scheme. Fashion choices are a declaration to the world of how we feel about ourselves. The men of Act I wear only neutral colors; they have a rigid sense of what is proper for their gender and all stay within those lines. The women wear soft tones to accentuate the demure qualities associated with feminine traits. In Act II societal rules are more relaxed and allow for more individual expression. This freedom of choice is represented by the bright colors and 
patterned fabric in their costumes. Each character has a style of clothing that they wear which will be discussed at length in the Research section of this paper.

Figure 4 is a piece of art by Malaysian artist, Sophia Kamal called "Just Pastels". This piece is sensual with a chaotic energy that feels disjointed and distorted and matched the energy of Act II. Two pieces of untitled work by artist Ana Godis, (Figures 5 and 6) use bright colors and dramatic line quality to create images both lifelike and cartoonish. The eccentric nature of these pieces connects with some of the more dramatic moments in Act II, where the "fourth wall" is broken. The "fourth wall" is the imaginary barrier between the audience and actors wherein the actors pretend to be real people living the events of the story while the audience watches the events unfold. Both Betty and Gerry have monologues where they speak to the audience about their inner thoughts and their sexuality. Figure 5 and Figure 6 have bold white lines on top of the main figures that disrupt the design, but also emphasize the gaze of the figures. This visual disorder captures the unsettling feeling of being directly addressed by actors onstage, as it is a break from the usual theatre etiquette.

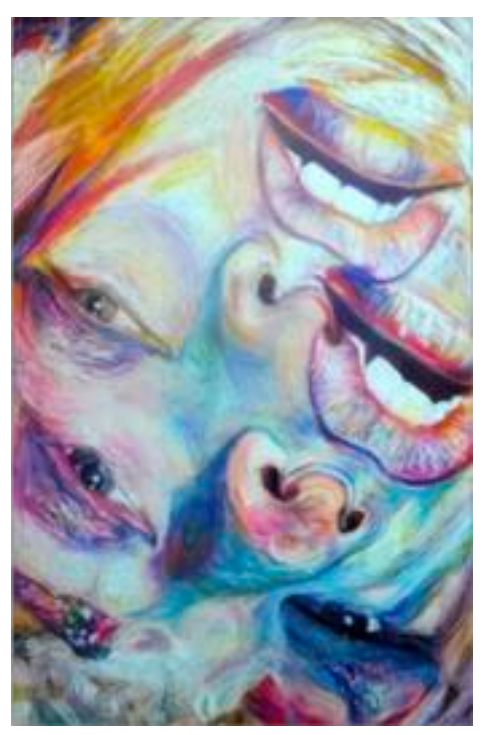

Figure 4: Just Pastels by Sophia Kamal 


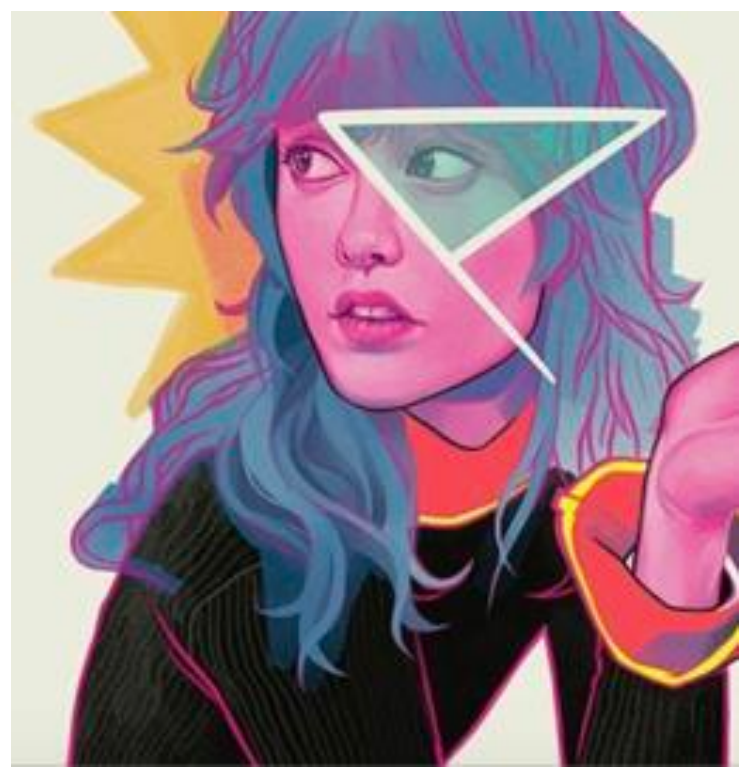

Figure 5: Untitled work by Ana Godis

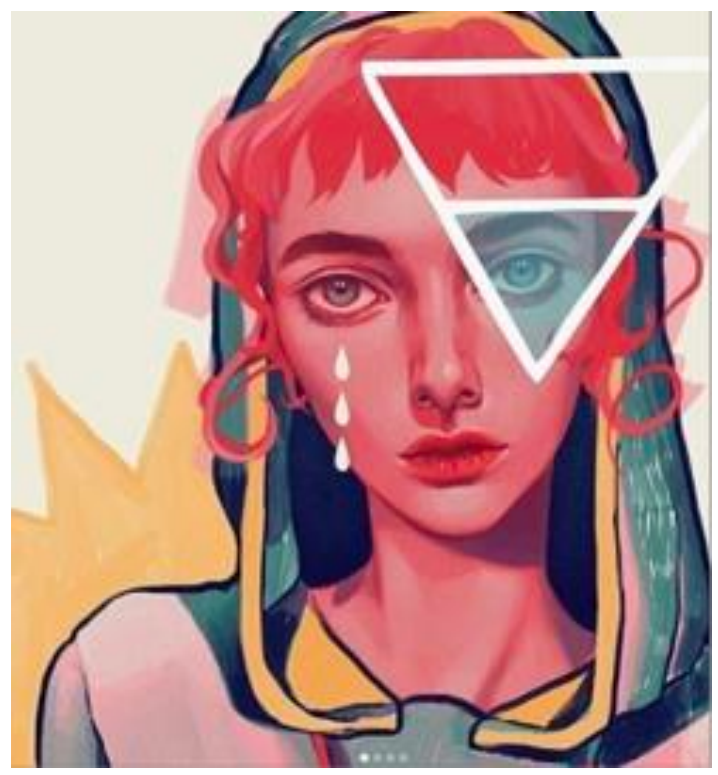

Figure 6: Untitled work by Ana Godis

After finding these initial emotive images, I continued researching design approaches.

My first idea was to have the play solidly based in realism. Having the costumes be realistic establishes the time periods for both acts. This also helps the audience create a mental framework for the events of the play that is grounded and relatable. This entailed period-accurate costumes for both British 1870 styles in Act I and that of the modern Los Angeles or New York in Act II. The colors of Act I would be washed-out or pastel, perhaps sun-bleached and Act II would have more extreme use of color and patterns. The washed out look of the 1870's would be like viewing a faded photograph. In contrast, Act II in 2018 would be bright and saturated, replicating the culture we currently experience.

The second idea presented to the director was more abstract and surreal in nature. Having extravagant and bizarre costumes would heighten the absurd nature of the characters' actions. By creating an environment that is fantastical in nature, it becomes easier for some viewers to critique the characters' actions. Act I would look bare-bones, tight and restricted versus Act II which would feature costume shapes that were slightly enlarged therefore also affecting 
movement. The Victorian costumes (Figure 7 And Figure 8) would not focus on period accuracy, but more of the feel of Victorian understructures. The exposure of corsets and other undergarments such as bloomers and petticoats without the trappings of being covered with traditional clothing would emphasize the restrictive qualities of the garments. In contrast, the modern-day look of Act II would be stylistically structured with exaggerated forms, (Figure 9 and Figure 10). Instead of exposing the constrained qualities of what lies beneath the surface, the structured shapes would show more individual personality while still compromising the characters ability to move freely. This juxtaposition would show that while over time societal pressures might change, new problems may arise.

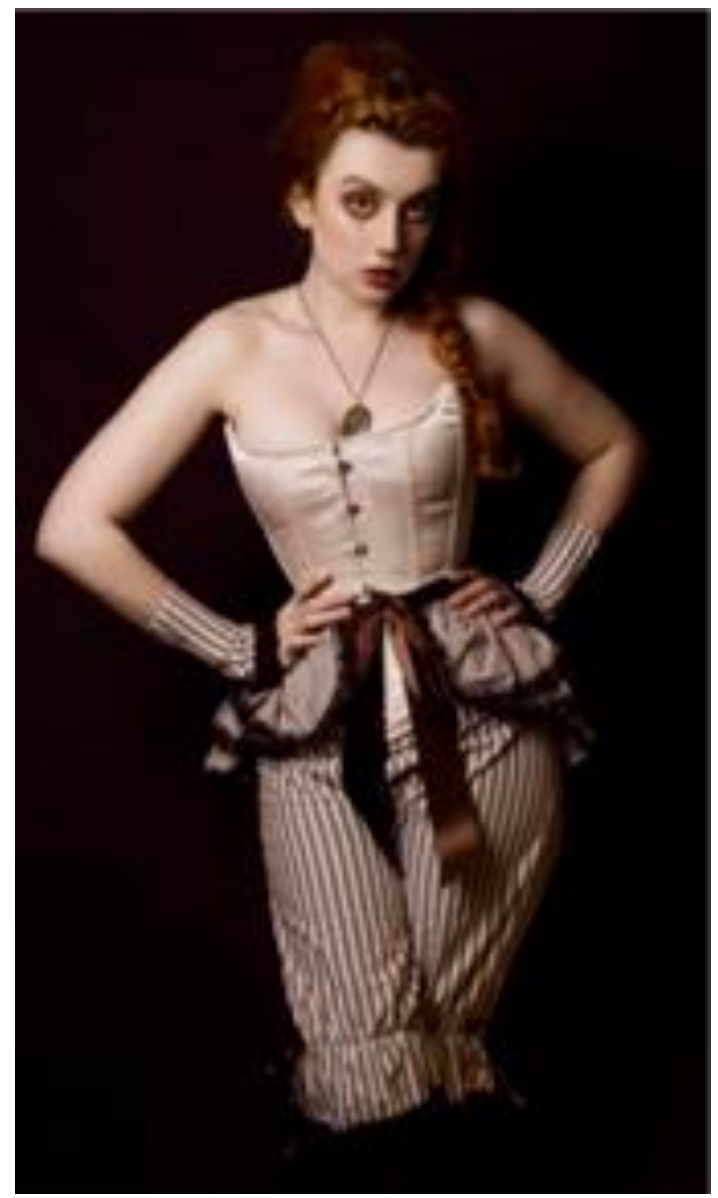

Figure 7: Research idea for Act I

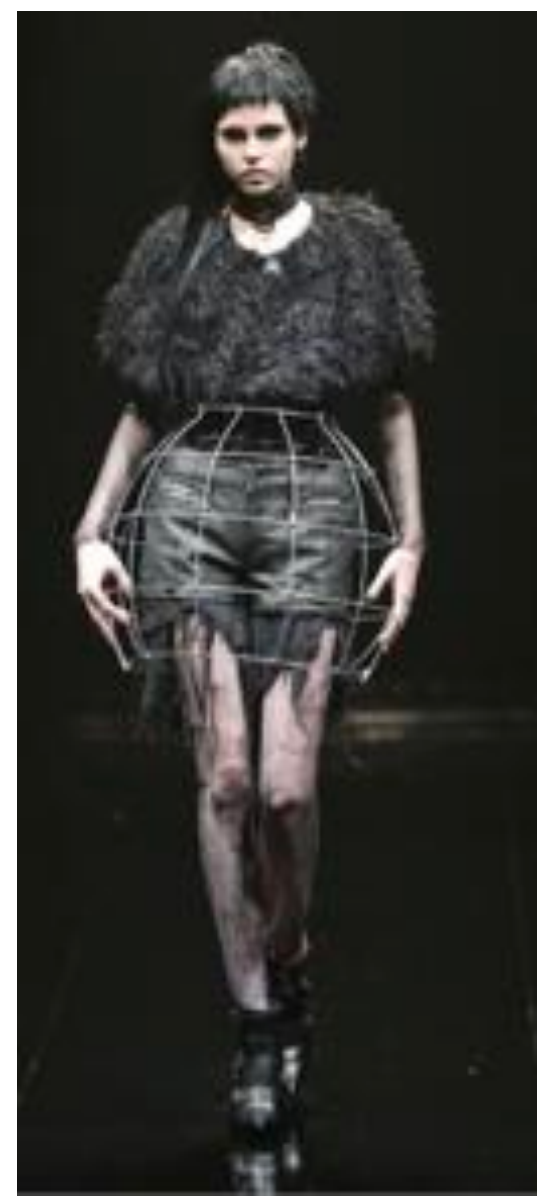

Figure 8: Research idea for Act I 


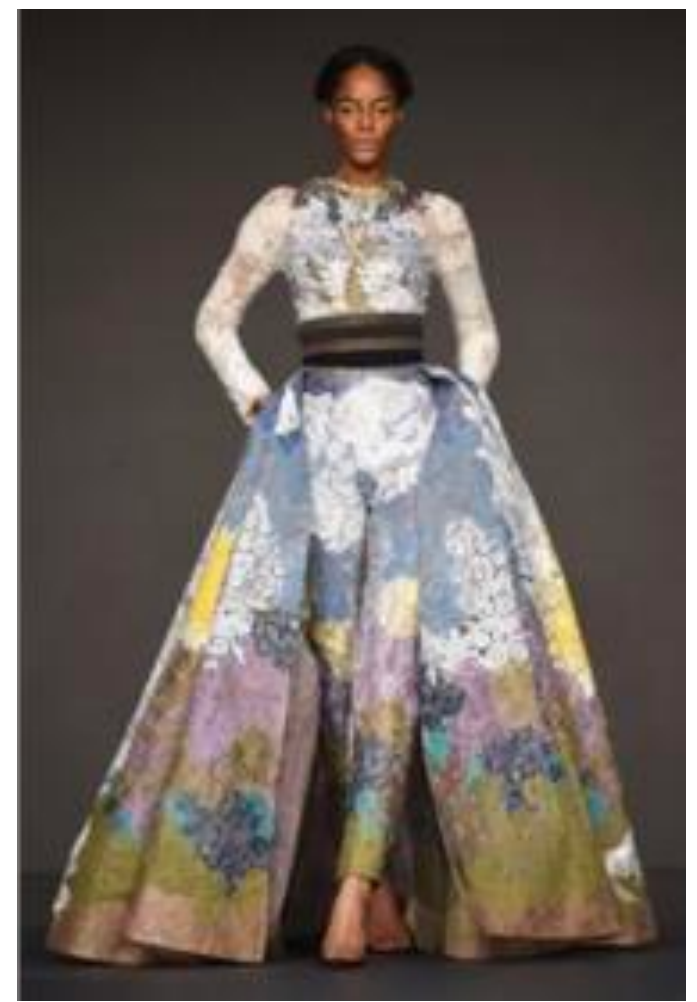

Figure 9: Research idea for Act II

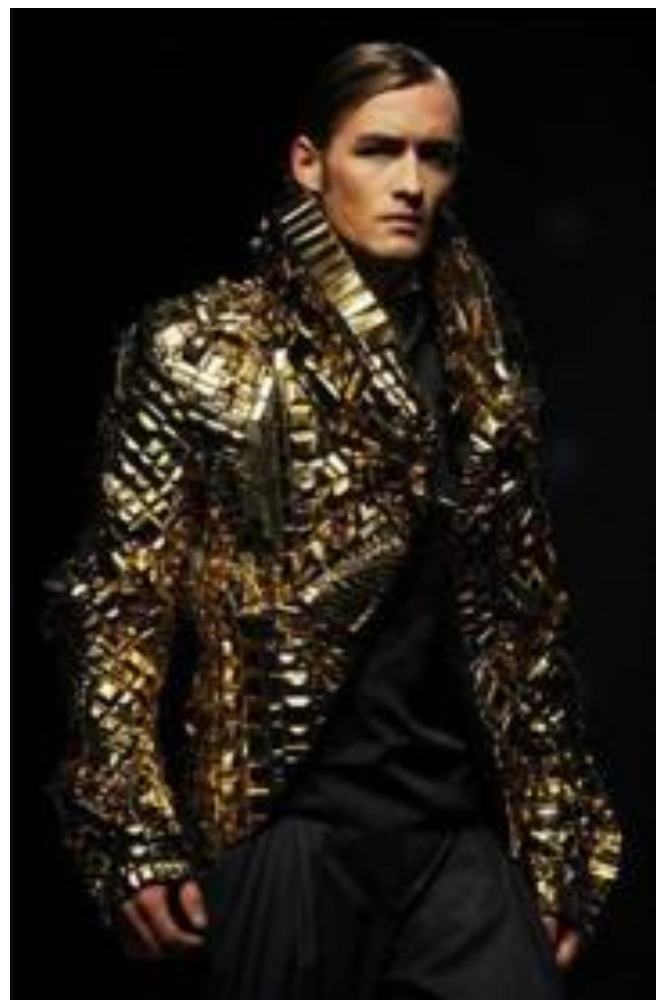

Figure 10: Research idea for Act II

In addition to the ideas of realism and abstraction of the costumes, a third idea occurred to me while looking through an art magazine called "Hi-Fructose". It was inspired by Zoey Taylor and David Connelly, the creators of an art installation called "Dosshaus". The installation consisted of pieces that were "highly manipulated, sculpted pieces that gave the illusion of everyday objects from an alternate, animated dimension. (Figure 11 and Figure 12). "[The] cardboard world [was] at once separate from and a comment on our modern culture" (Dosshaus). In this version of the play the world would be extremely stylized and have a Pop-Art like quality. This approach would emphasize the artificial quality of watching a scripted piece. While Cloud 9 is a serious play, it is still a "scripted" slice of life. This direction could have helped the audience members recognize the performance as an art piece (the play itself) and that everything in front of them is a series of scenes that are pieced together for the sake of storytelling. The 
artificiality would be emphasized by the very blatantly fake quality of the costumes, props, and scenic design.

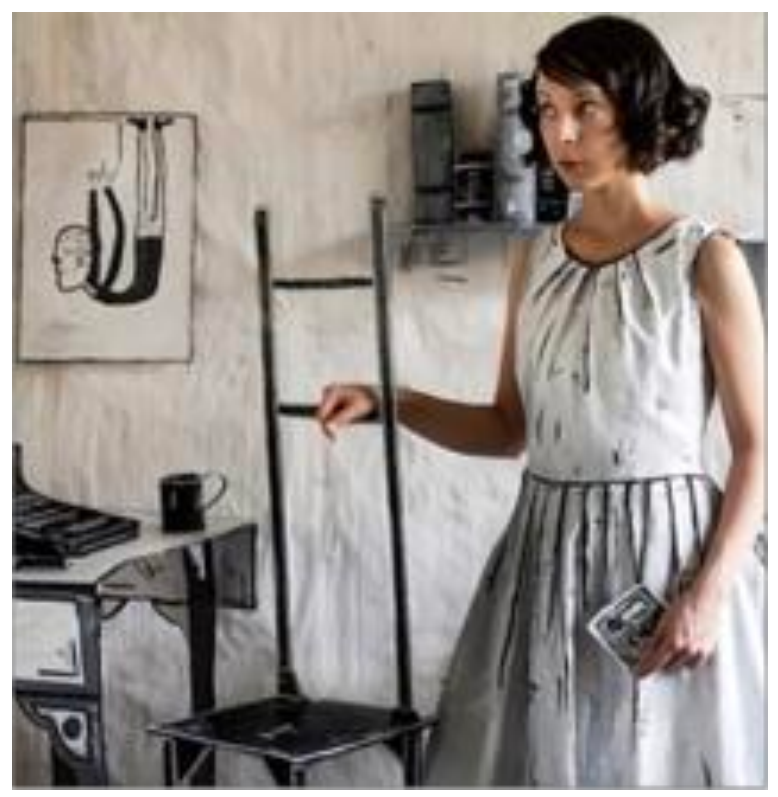

Figure 11: Zoey Taylor in "Dosshaus"

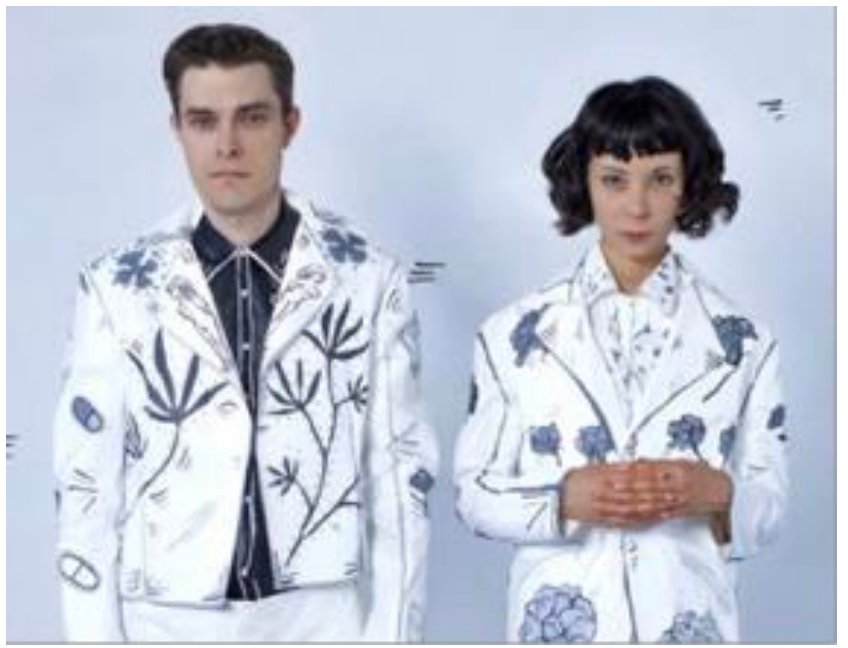

Figure 12: David Connelly and Zoey Taylor

When talking with the Director, she suggested a combination of two of the ideas. Act I would have the stuffy and overbearing, but ultimately realistic Victorian clothing and Act II would have "Dosshaus" inspired clothing. Even after choosing a conceptual approach, the research continued and the direction changed with several rounds of sketches. As time passed the designs began evolving as I moved into more "character centric" research. There was still heavy and restricting Victorian inspired clothing suited for a cool, damp British climate in Act I which helped to suggest that the characters were out of place and unprepared to live in an African climate. Victorian fashion also had a high-mindedness and rigid sense of propriety. Women wore boned corsets and layers of petticoats to achieve the desired silhouettes. Men also wore many layers over their shirt and trousers, including waistcoats, jackets, and accessories like cravats. When colonizing countries with much higher temperatures, the early British attitude was that the environment must adapt to their ways rather than the colonizers to the environment. They also 
tended to view the locals as less sophisticated than themselves and improper for wearing light layers of fabric with exposed skin instead of seeing the practicality of these choices.

Conversely the costumes for Act II moved toward modern ready-to-wear styles that played with general stereotypes for each character. The modern looks show a variety of styles that embraced the personality of the individuals. Character costume styles are discussed further in the Research section.

In terms of color between costumes and the set, the Scenic Designer, Lindsey Mariano, initially discussed being inspired by the painting “The Garden of Earthly Delights" by Hieronymus Bosch (Figure 13). This led me to stay away from the color green as I did not want any of the characters to blend into the background. As the design process developed, Mariano strayed away from the "The Garden of Earthly Delights" and became more inspired by the work of African artist Jane Alexander. Alexander is an instillation artist whose work "express[es] 'the fragility of a multicultural society' in the post-apartheid era." (Deutsch). Her piece "African Adventure" (Figure 14) is a collection of figures that are "neither human nor animal, [and] are simultaneously emblems of monstrosity and oddly beautiful" (Tate). Mariano combined the isolation and sculptural elements of Alexander's work with the visual element of African nail fetish sculptures. Nail Fetish:

Is one of the most recognizable and collectible figures in all of African art. These life-like figures are instantly identified by the many nails, pegs, blades, and shards that are hammered into them. Each individual "insertion" represents one of three things: an oath or agreement between two parties, a pledge to provide protection against enemies and witchcraft, or a vow of vengeance. (Imagawa)

The combination of these new influences drastically changed the set design and the color palette of the show from what we had previously discussed. My only worry with the changes was that if we both used too many tan and brown colors, the set would engulf the costumes and the 
characters would easily disappear in their surroundings. After a discussion about this, Mariano steered the set to cool tans and grays and I moved towards warm tan and browns. The Lighting Design also helped to emphasize the bodies in the landscape by highlighting the dynamic quality of the set designs sculptural characteristics. Thomas Gillette discussed wanting to create the atmosphere of the African surroundings in Act I and really focused on the time of day in each scene. In Act II not only does the time of day change but also the seasons. These factors influenced not only the amount of light, but also the tonal values of light Gillette chose to use.
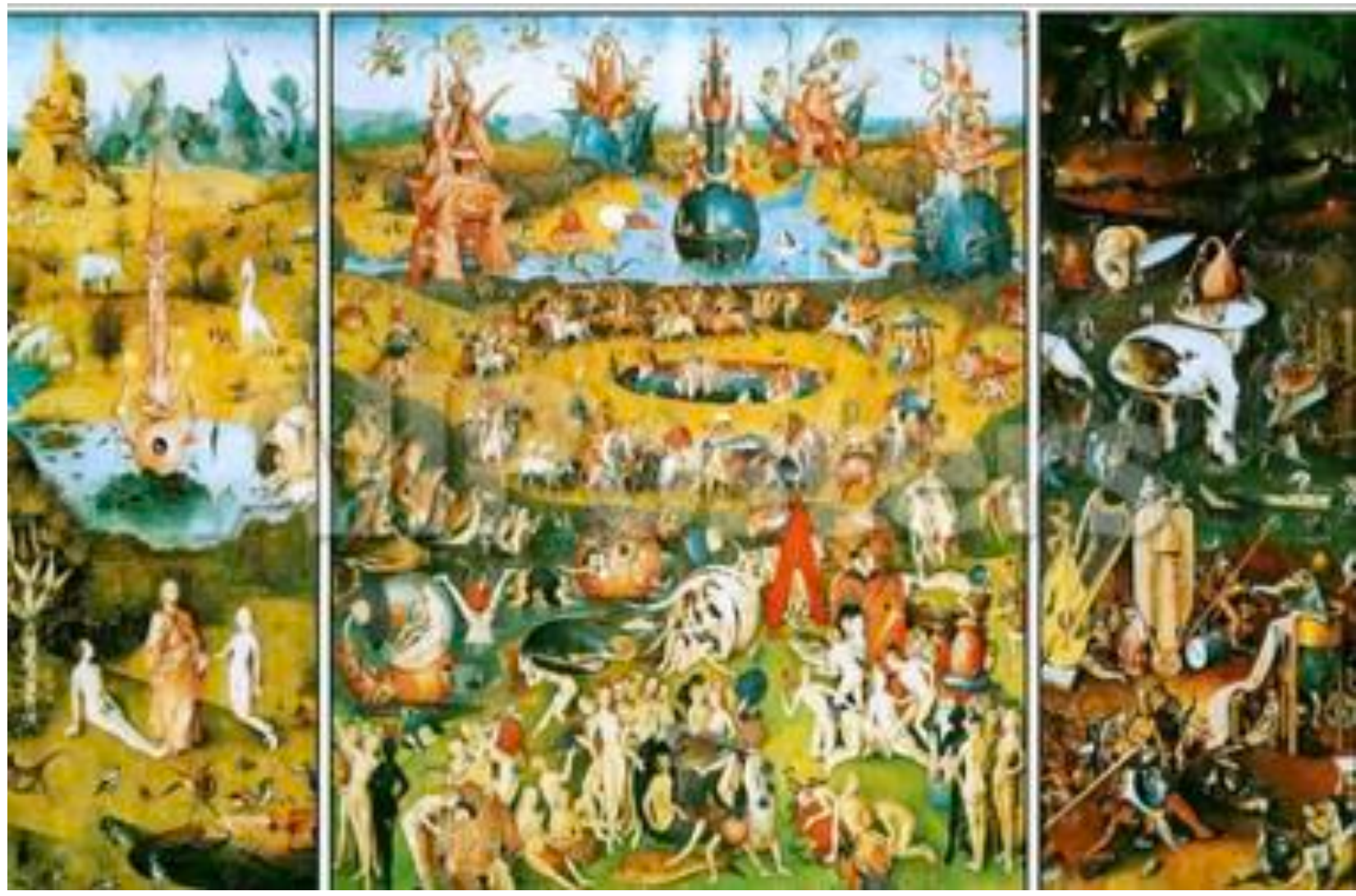

Figure 13: "The Garden of Earthly Delights" by Hieronymus Bosch 


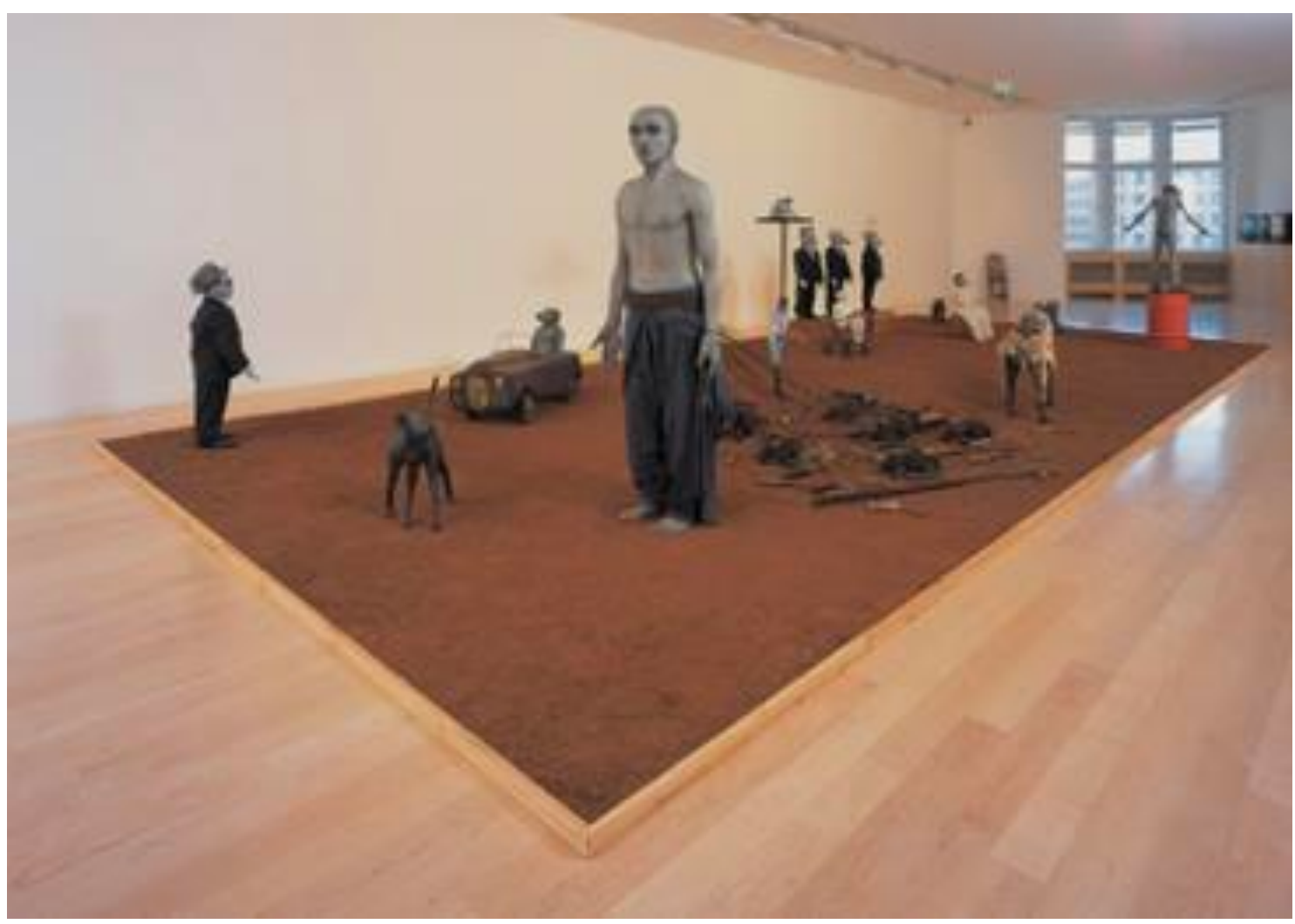

Figure 14: "African Adventure" by Jane Alexander 


\section{RESEARCH}

The next step of the design process was completing general research on the time periods for both acts. Act I takes place in British colonized Africa in 1870. Although the script does not say where in Africa the play takes place, it was decided that it would be set in South Africa. A book I referenced for images of British occupied Africa, called "Painting Africa White: The Human Side of British Colonialism" by Roy Lewis and Yvonne Fey, showed that across the African continent the British occupiers attempted to stay in rigid Victorian wear despite the climate of Africa being at a much warmer temperature than England. Figure 15 shows British occupiers playing tennis in Africa, going as far as to praise the subjects of the photo for flourishing in the heat. Figure 16 is a group photo taken in South Africa, yet the architecture of the building shows the British brought with them their own style ideals as they occupied foreign territory.

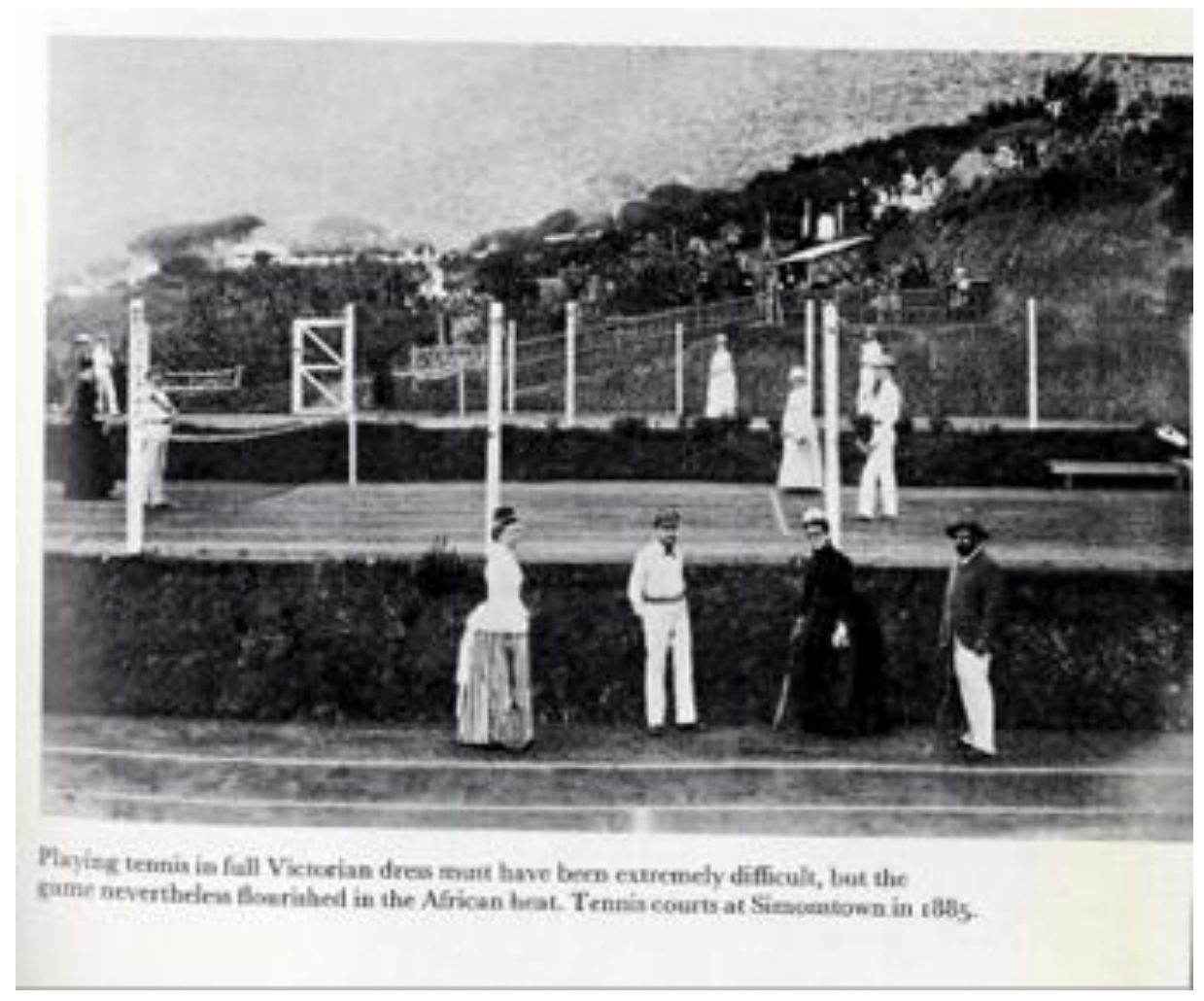

Figure 15: A photograph from "Painting Africa White: The Human Side of British Colonialism" by Roy Lewis and Yvonne Fey 


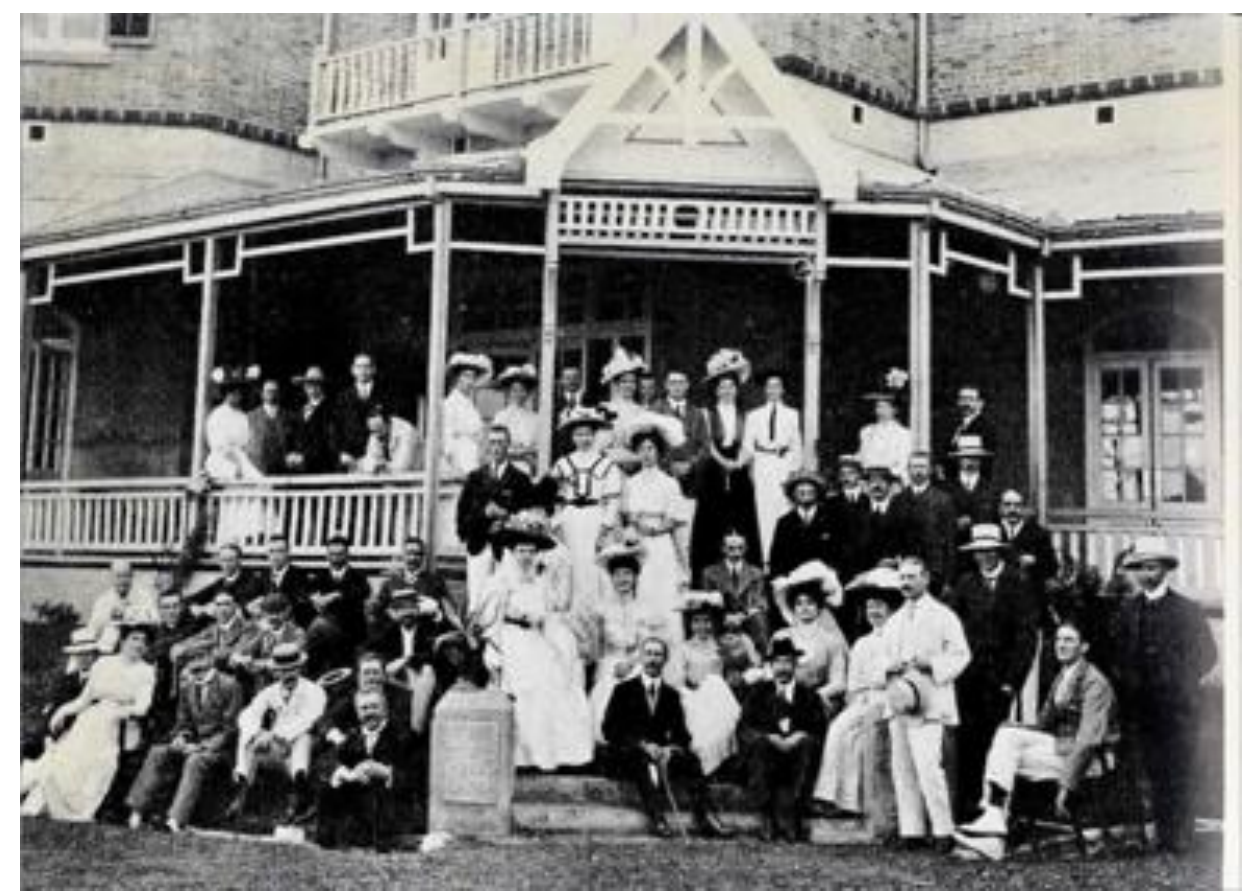

Figure 16: A photograph from "Painting Africa White: The Human Side of British Colonialism" by Roy Lewis and Yvonne Fey

For Act I, I stayed away from busy patterns and bright colors to capture the true feeling of the Victorian clothing. This decision combined with the brown and grey set design would hopefully create a feeling of barrenness. In contrast, Act II would be bright and busy with color and pattern. This contrast would further highlight the influence time has made on the characters' ideas of themselves and what they consider proper to wear in society. Through their clothing we get a glimpse of their inner psyche.

I moved into assembling collages for each character creating a general "look book" to further clarify their costume design. This allowed me to have several images in one place to show the director, to make sure we generally connected on how each character was to be represented. The full collages for each character are located in the Appendix B "Look Books".

Clive's research was based on images of David Livingstone (Figure 17), who was a famous Victorian explorer in Africa. He was also influenced by other historical images such as Figure 18. At this time, I played around with the idea of the fabric of his suits having touches of 
African batik textiles while maintaining an English suit silhouette (Figure 19). The idea being that he would be wearing the textiles of the land he is colonizing. For Clive's character this would be like a hunter wearing the pelt of an animal he has hunted, as an expression of dominance. In the end, it was decided not to pursue adding African textiles to Clive's costumes. As the ideal English man, his character is strictly influenced by British clothing standards. He started the show in full military wear and as the scenes progressed he took off layers as he relaxed (Figure 20-Figure 22). In the final scene of Act I he is dressed-up for Harry Bagley’s sudden wedding (Figure 23).

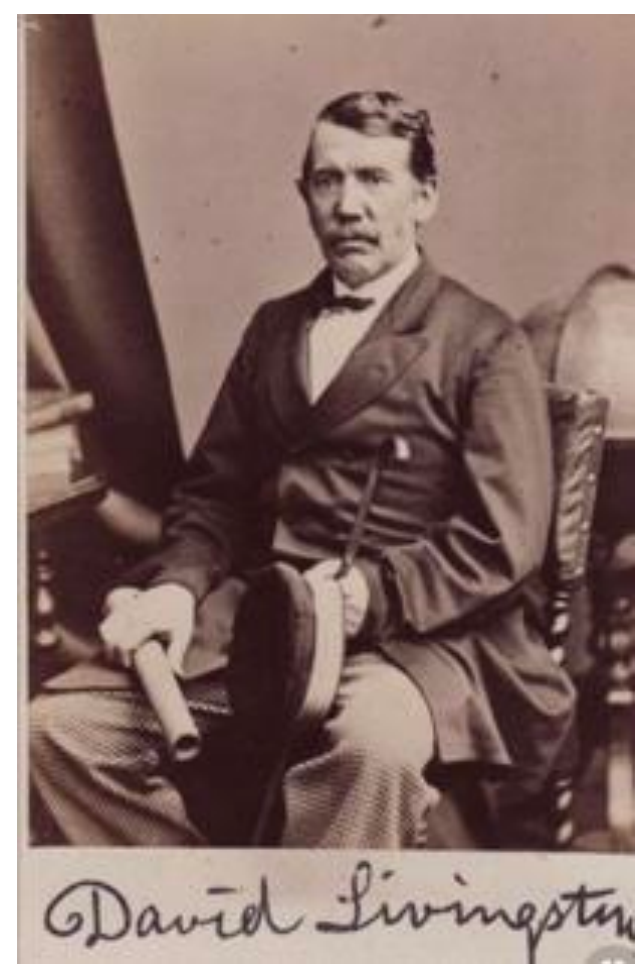

Figure 17: A photograph of David Livingstone 


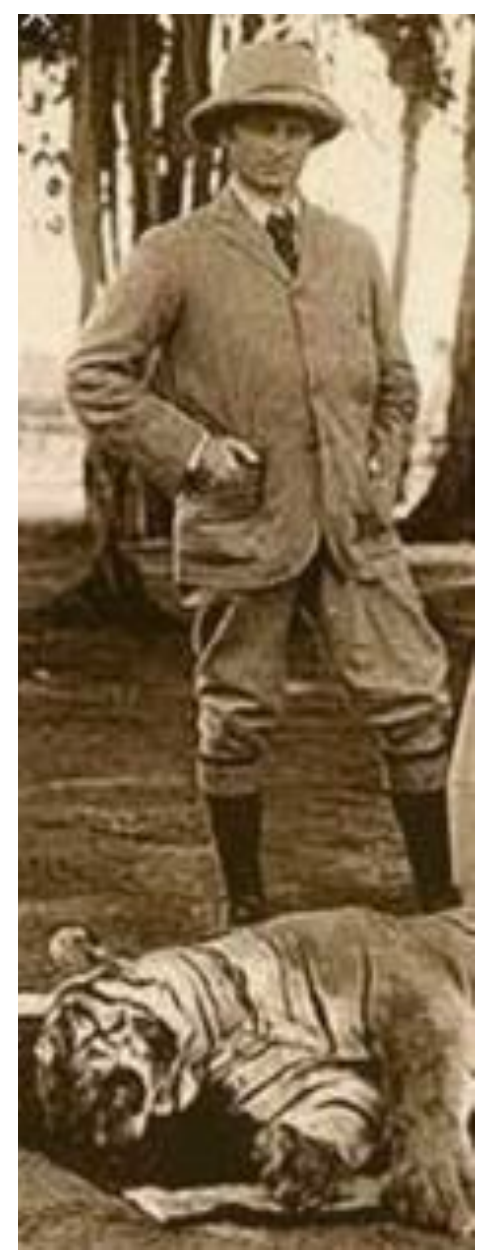

Figure 18: A research photo for Clive

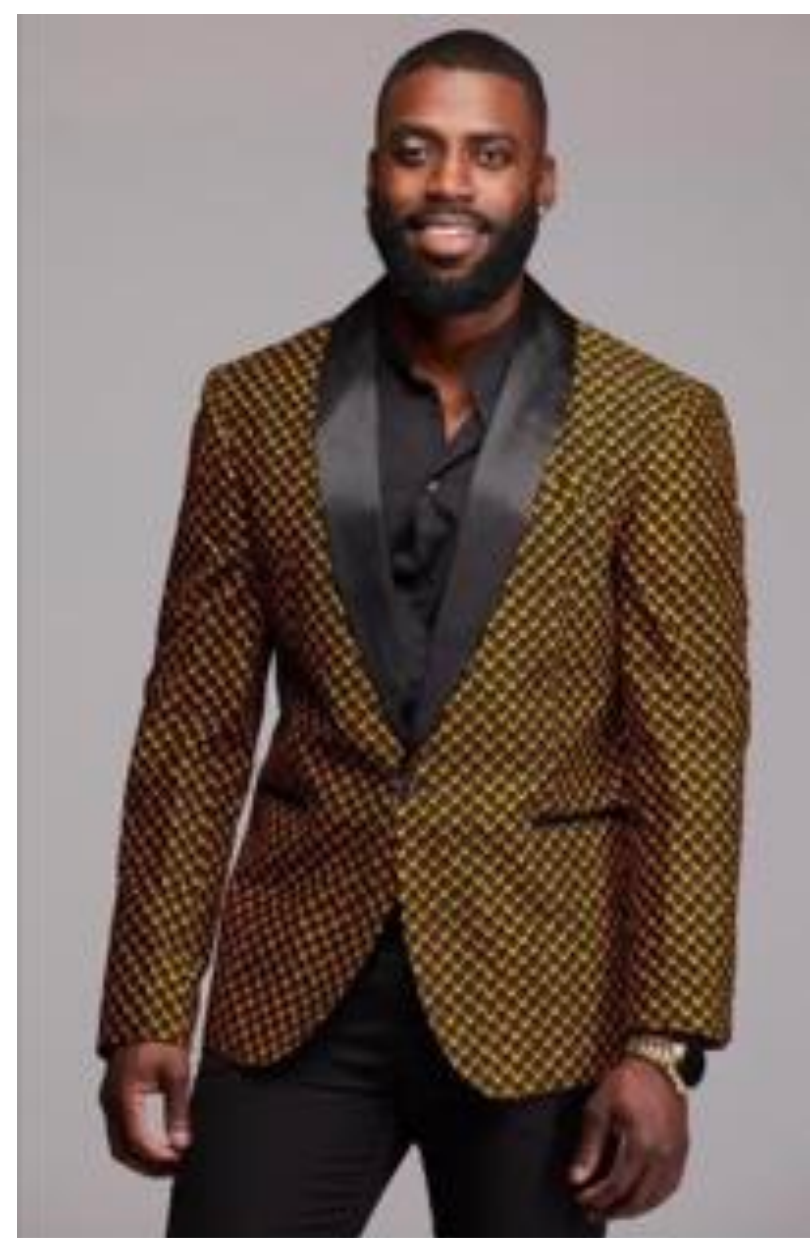

Figure 19: A research photo for pattern textiles use in men's suits. 


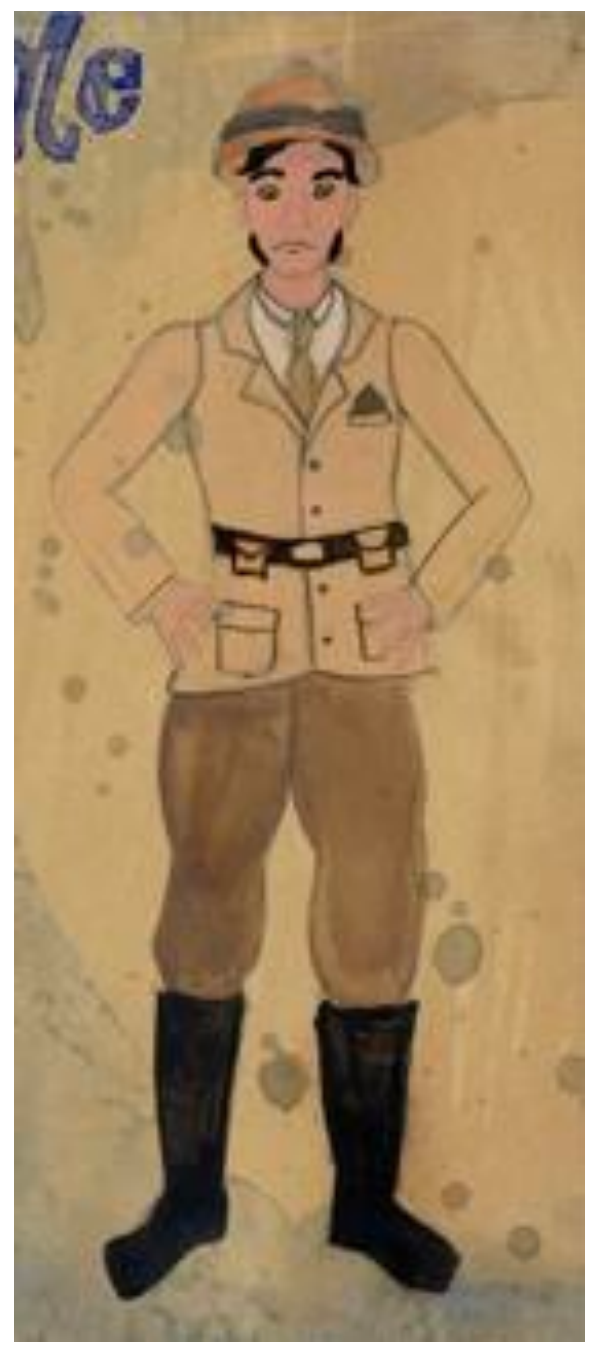

Figure 20: Rendering for Clive

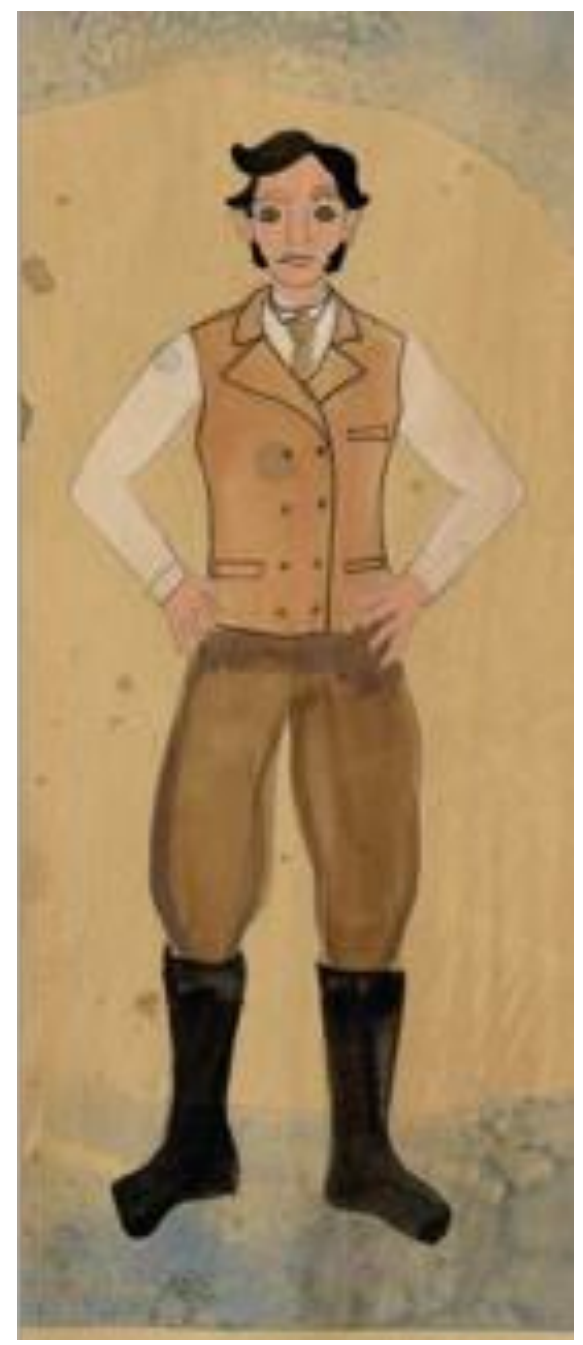

Figure 21: Rendering for Clive 


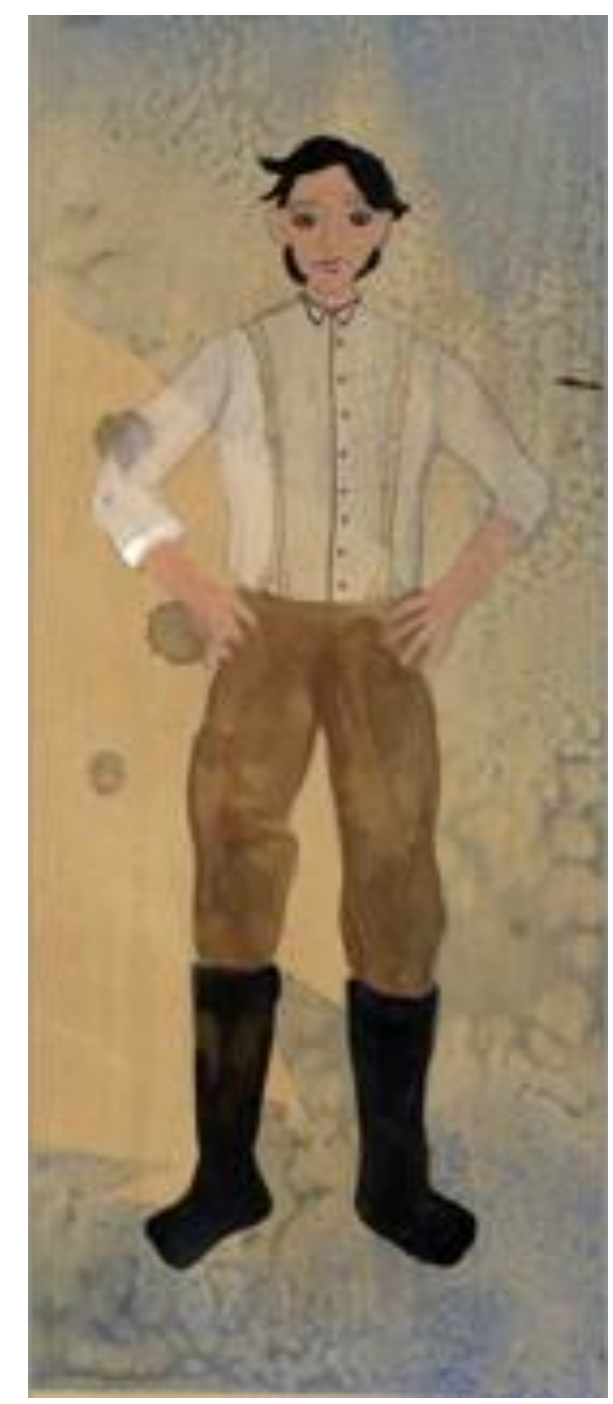

Figure 22: Rendering for Clive

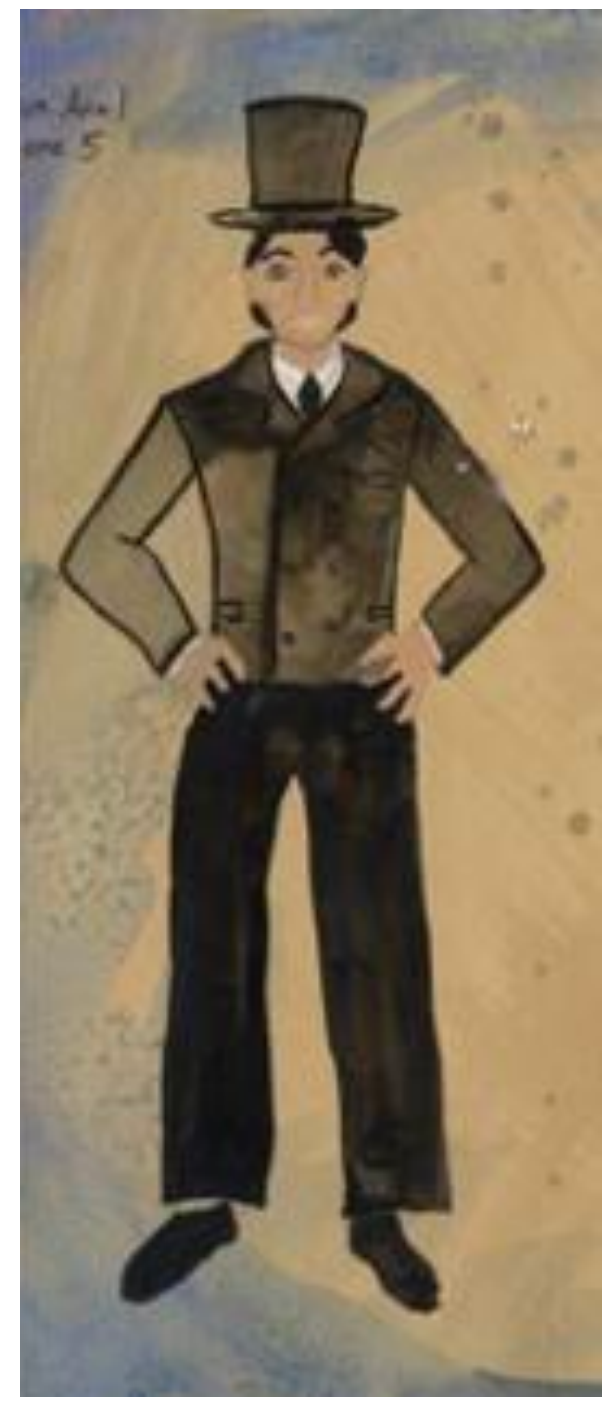

Figure 23: Rendering for Clive

The character Betty was inspired by images of Victorian day dresses (Figure 24). Even though she is in Africa, Betty is trying to stay current with English fashion styles. Even if she wishes for a more adventurous life, Betty is trying to be the Victorian ideal for Clive. To add to the family tension, Churchill places Betty's mother with her in Africa. Her mother Maud represents a traditional voice who comments negatively on her wardrobe and life choices reinforcing Clive's patriarchal ideals. To satisfy the visual needs of the ideal Victorian woman, Betty needed small details, such as lace, decorative buttons, styled hair, a handkerchief and makeup to show her social status. I was inspired by a figure of a Victorian woman wearing bold 
stripes for Betty's signature dress (Figure 25). Not only were stripes a common Victorian pattern, but the verticality of the stripes would help emphasize and exaggerate the built-up feminine figure of the male actor playing Betty, as the strips would curve over the body suit accentuating the bodies curves. It was discussed early in the process that the character of Betty should be more realistic and not a stereotype. We decided that the fact that Betty is played by a male actor was something to be taken seriously and was not designed to be campy or satirical in any way to be played-up for audience amusement.

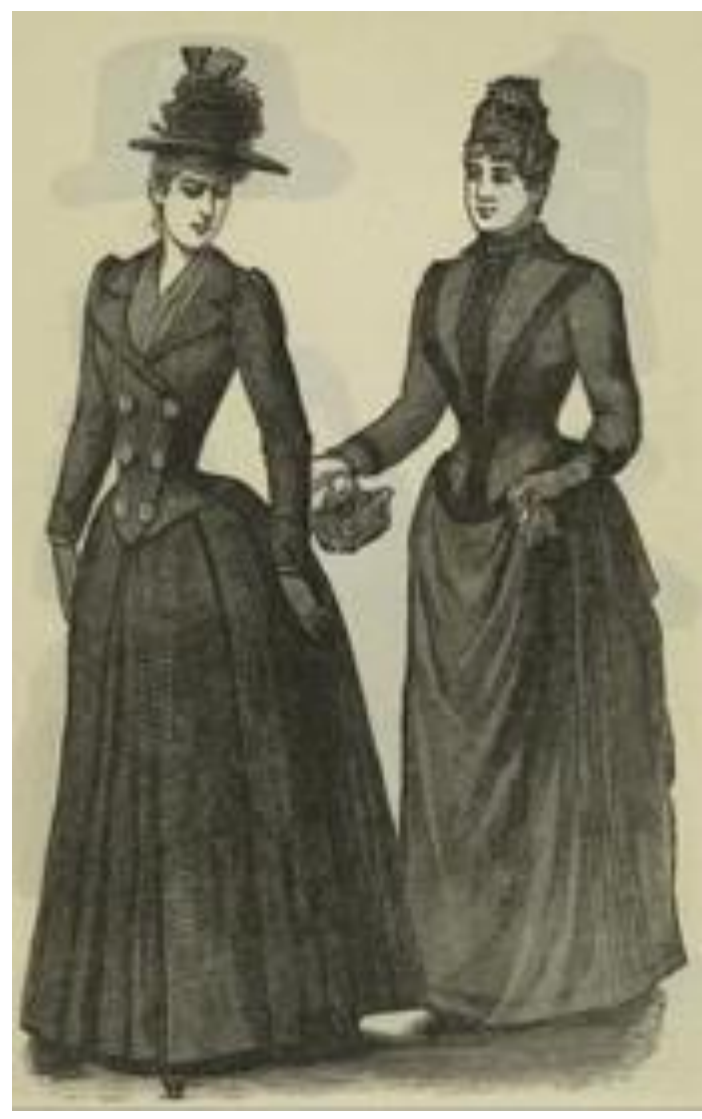

Figure 24: Research for Betty, act I

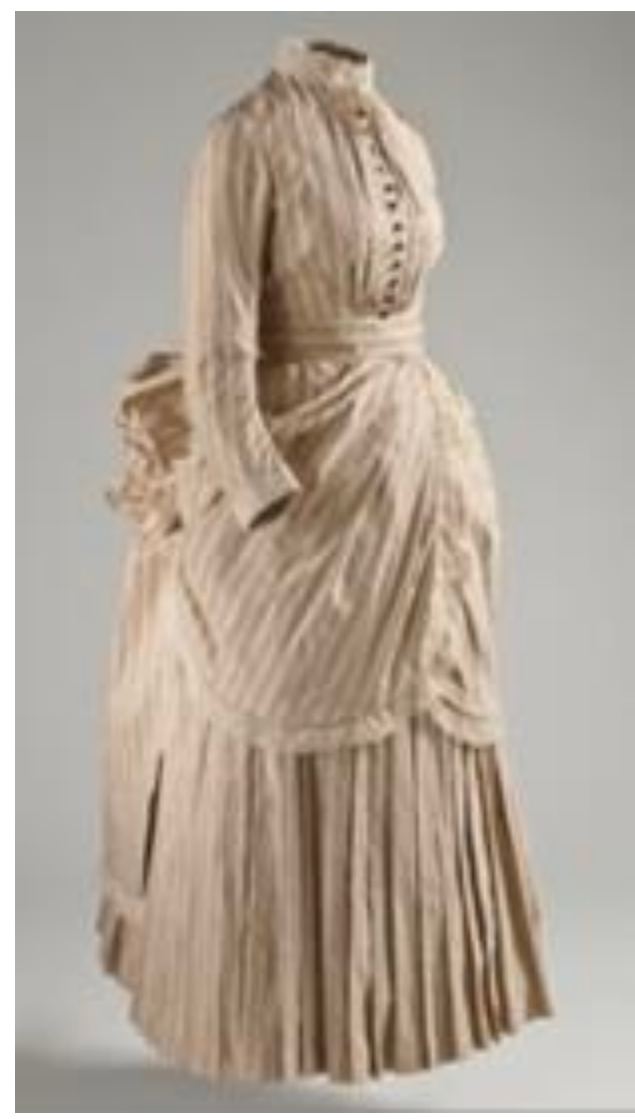

Figure 25: Striped Dress Research for Betty 
Originally Betty had five dresses, (Figures 26-30). I thought that Betty out of all the characters would be trying the hardest to appear fashionable in order to impress Clive. Yet having Betty be the only one to change with each scene felt forced. First it was not very practical for the scene changes and second visually she would be the only one doing so. Therefore, it was decided that the only major change would be for the final scene at the wedding where she would have a full costume change. Instead of a full change in each scene, Betty would have minor adjustments: this included different blouses and shawls. The final dresses chosen for Betty were Figure 26 for her main outfit and Figure 30 for her wedding scene dress.

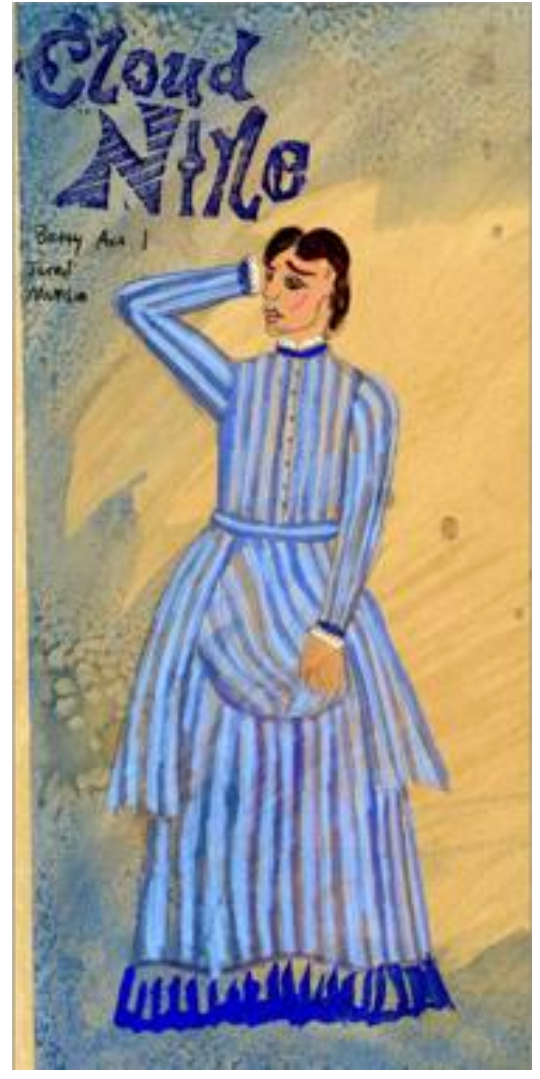

Figure 26: Rendering for Betty Act I, dress one

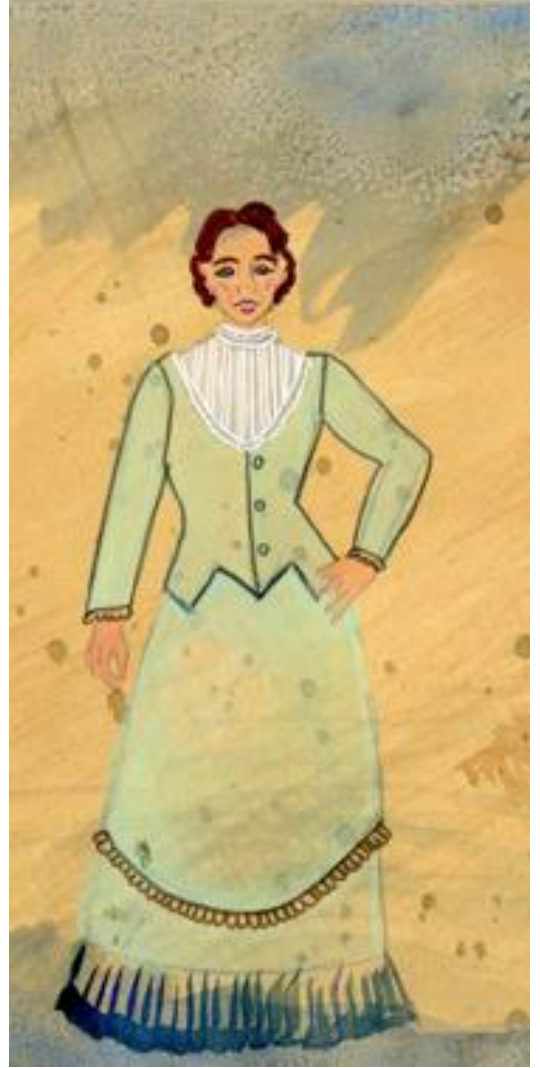

Figure 27: Rendering for Betty Act I, dress two

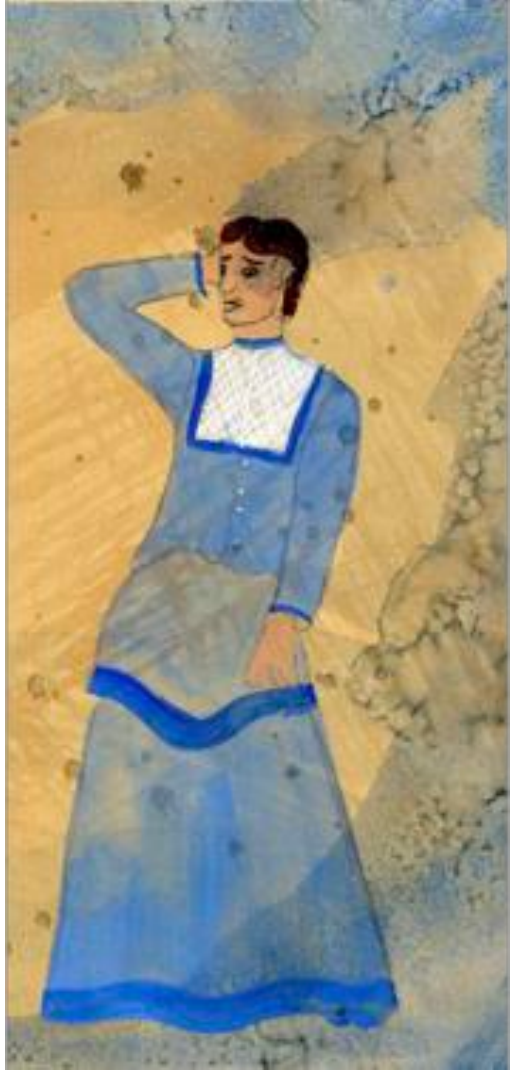

Figure 28: Rendering for Betty Act I, dress three 


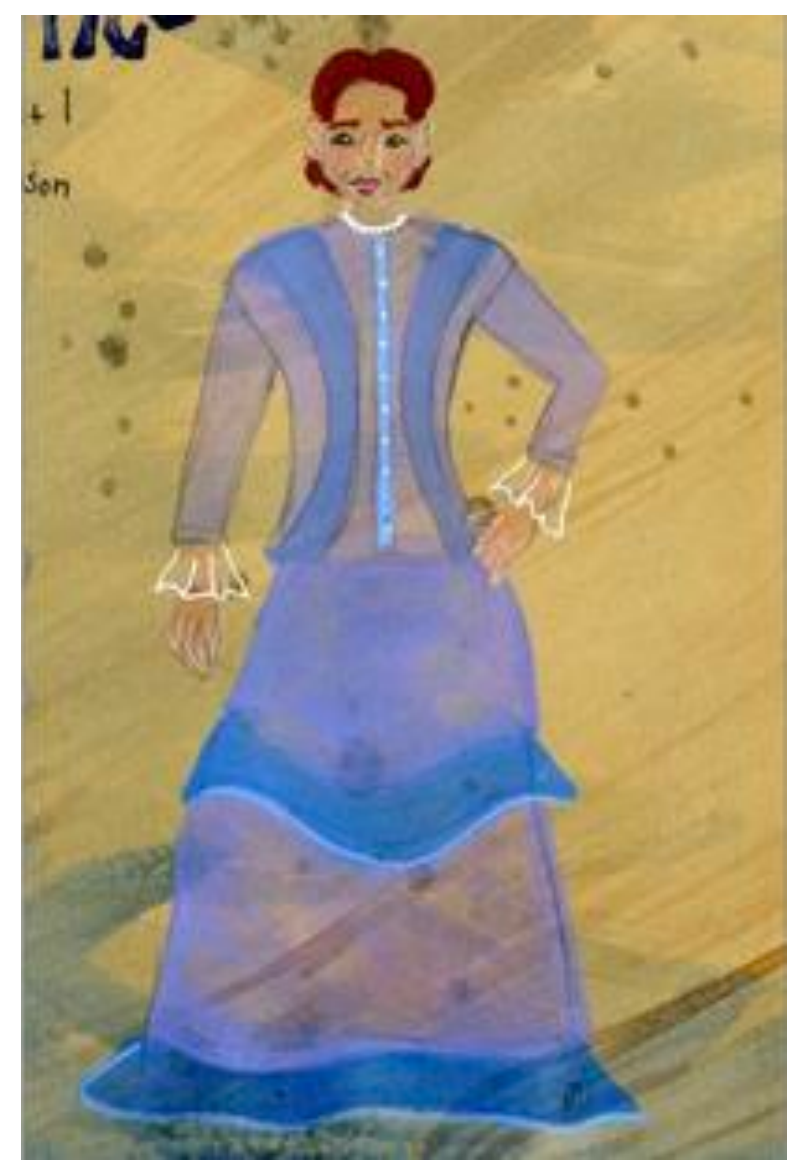

Figure 29: Rendering for Betty Act I, dress four

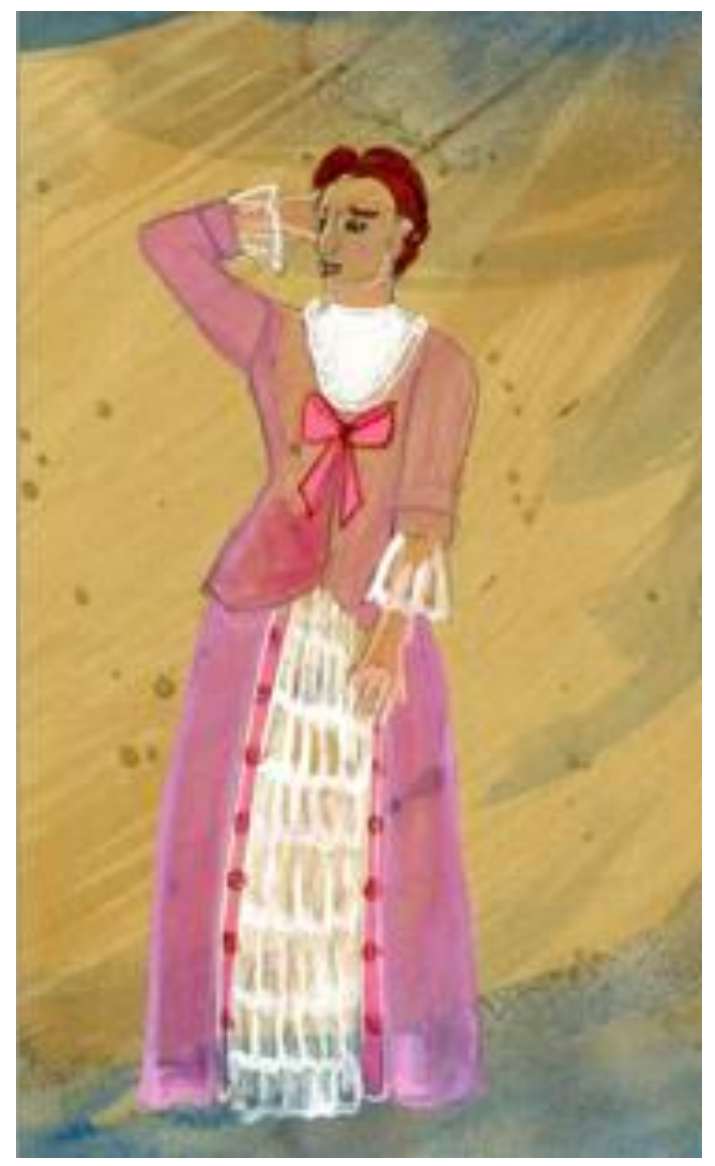

Figure 30: Rendering for Betty Act I, dress five

Originally, I had multiple ideas for the character of Joshua. My first idea was that Joshua would be heavily saturated in African textiles with an English silhouette. This would complement the character Clive, who also could have had small details of African Batik textiles. This would show that while this character is trying to be English, his native colors live in more than just his skin tone. This idea was inspired by the work of Yinka Shonibare. Shonibare's work discusses colonialism and globalization through sculptural pieces made to mimic western fashion while using imported Dutch woven fabrics that are made to look like African batik prints. Such as the piece in Figure 31 named "How to blow up two heads at once (Gentlemen)". My second idea for Joshua, was that he would not be wearing Victorian styles, but more African styles (Figure 32). This option would show that while Clive values him as an African servant, he does not go as far as to provide him with new clothing. 


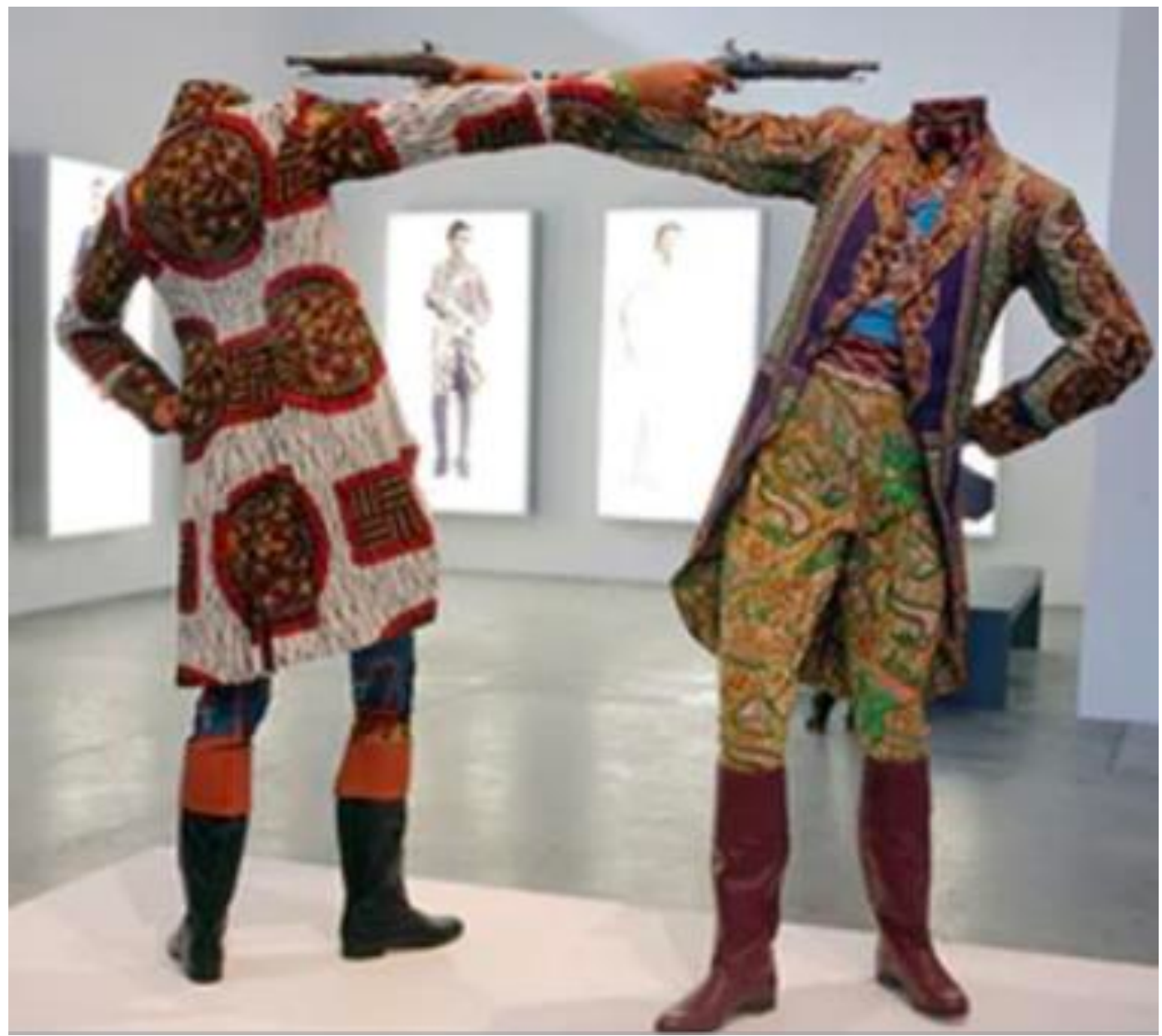

Figure 31: "How to blow up two heads at once (Gentlemen) by Yinka Shonibare 


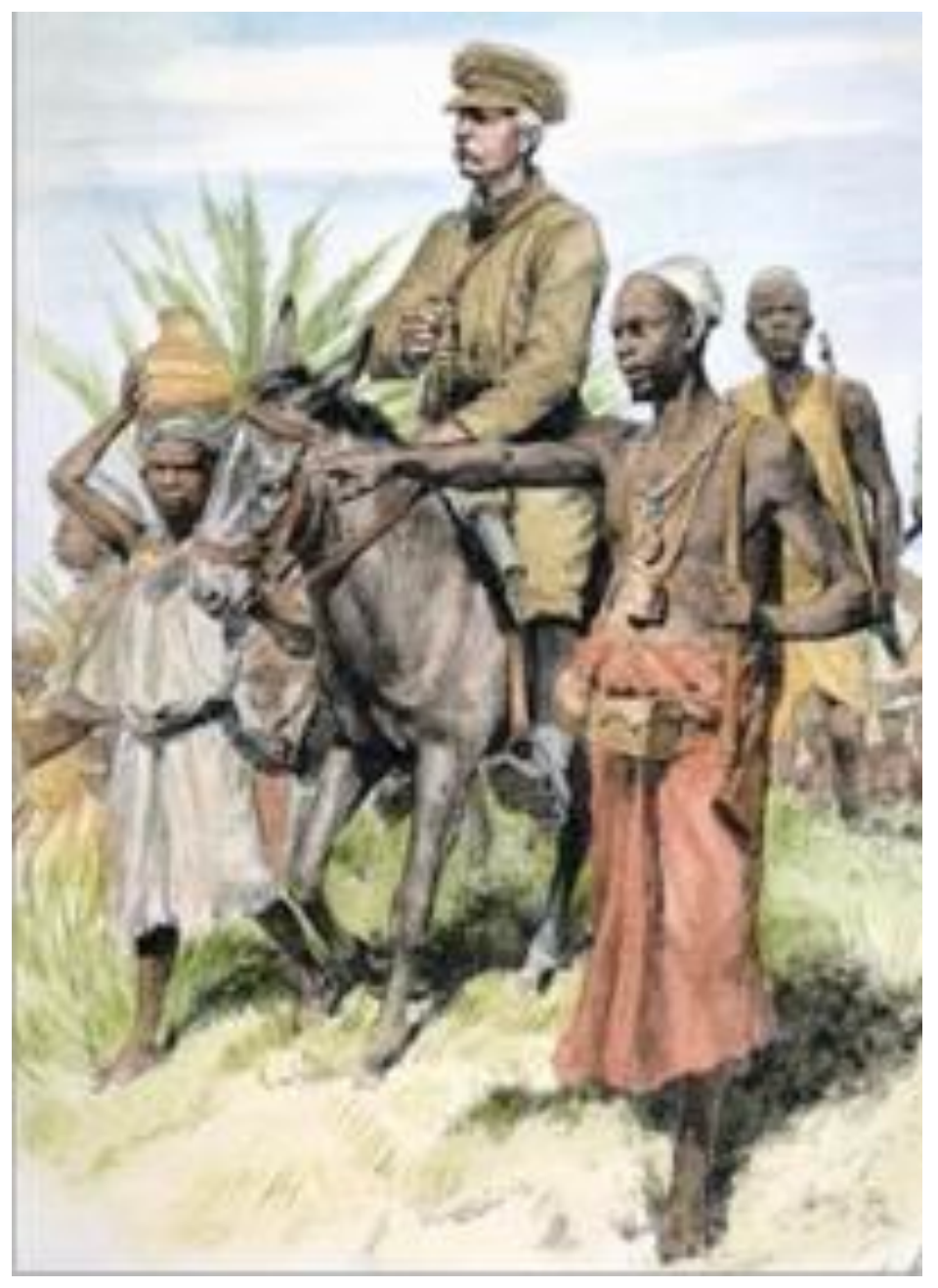

Figure 32: Historical archive

After meeting with the Director, some changes were made in the direction of Joshua's character. Both my ideas had him visually tied in some way to being African first and foremost, even if he wished otherwise. The Director wanted to emphasize that he cast off his ties to Africa. Visually he would be wearing an English man's suit, something that was provided by Clive. The suit could be ill-fitting in some way, as if Clive didn't try to make sure it was his size. We discussed several ways we could differentiate Joshua. Originally, we moved towards the idea of scarification, the process in which deep scars are made in a certain pattern typically associated with coming of age ceremonies. Through discussion about the show, I found that the dialect coach was directing the actor to perform a South African accent. In my research, I could not find 
a South African tribe that readily performed scarification. It was decided that it felt forced to use scarification in this situation and was uncomfortably close to using blackface in performance. Joshua's final costume design is Figure 33.

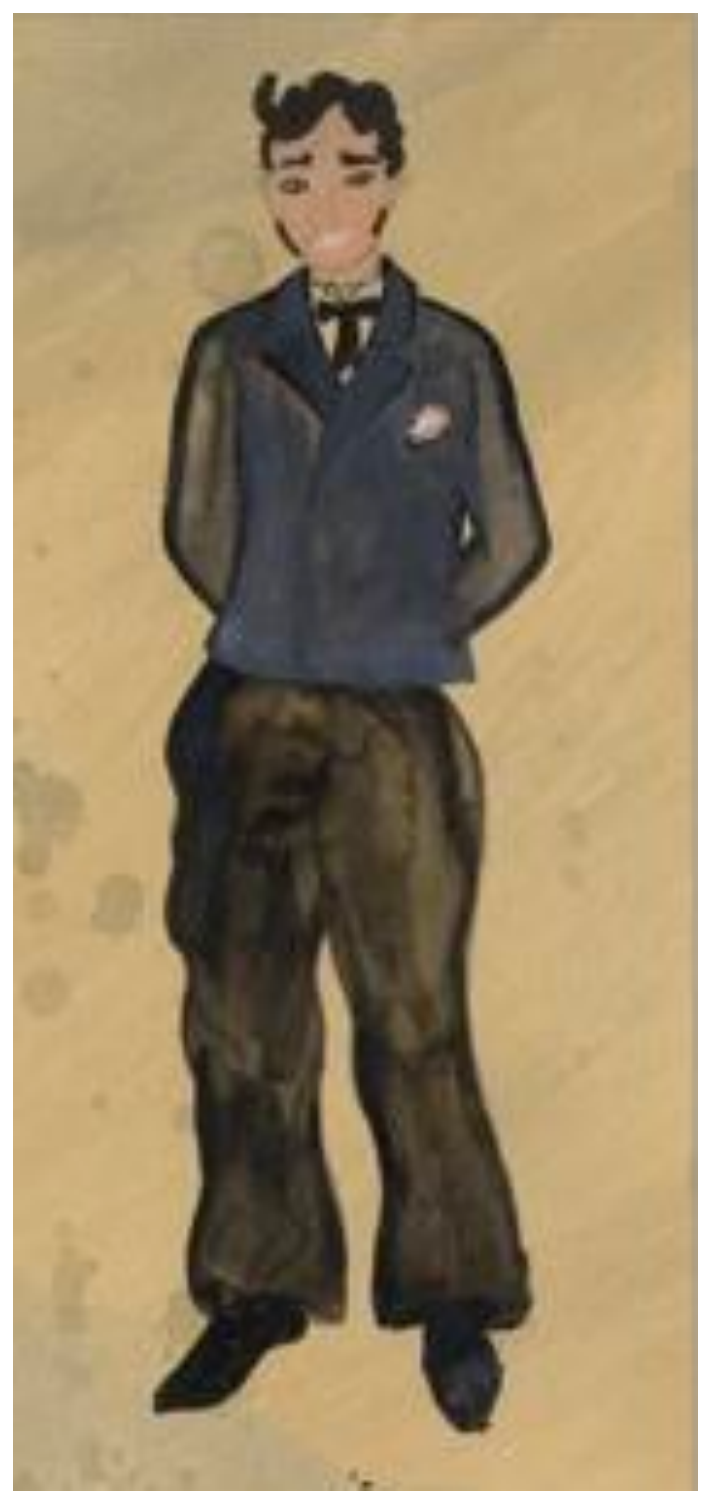

Figure 33: Rendering of Joshua

Edward's costumes were inspired by images of Victorian children and extant garments such as Figure 34 and Figure 35. As Clive's son, the character is very smartly dressed. As a representation of England to those in Africa, Clive views himself as an extension of the British Empire and therefore his only son, Edward is under pressure to live up to Clive's ideals. When he introduces himself, Edward states, "What Father wants I'd dearly like to be/ I find it rather 
hard as you can see" (Churchill 6). Churchill makes this evident to the audience by casting a woman in a man's role. Edward being played by a woman represents the internal conflict Edward is having exhibiting feminine characteristics in a world that does not value femininity. Edward starts the show in a full suit and as scenes progress, takes off layers. By the end of Act I, Edward returns to their first scene costume and puts back on their full suit for the wedding (Figure 36 - Figure 38).

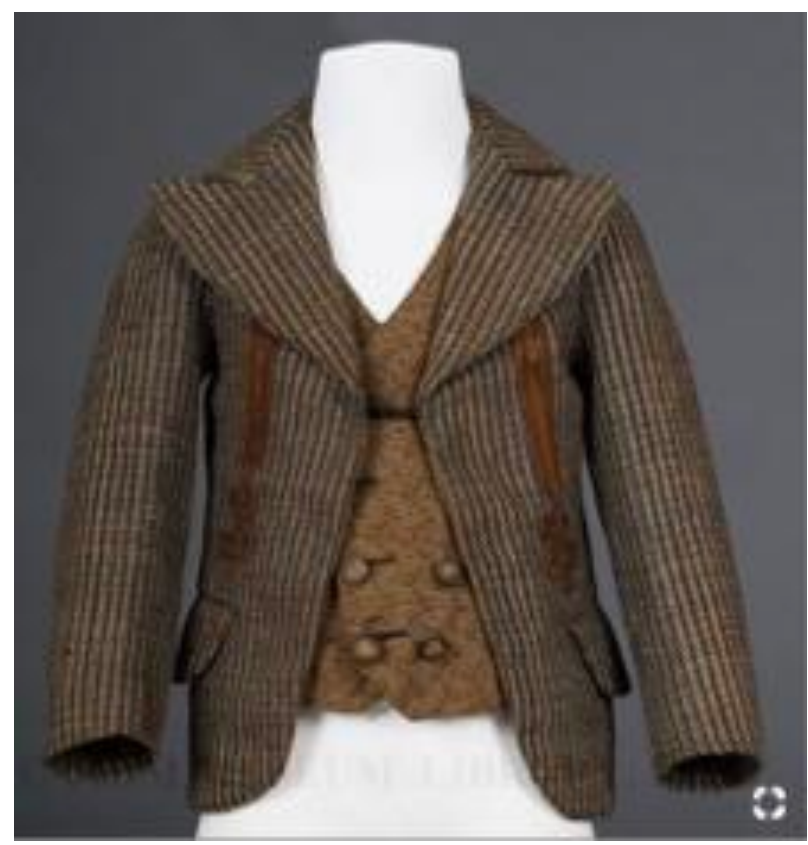

Figure 34: Historical child's suit jacket

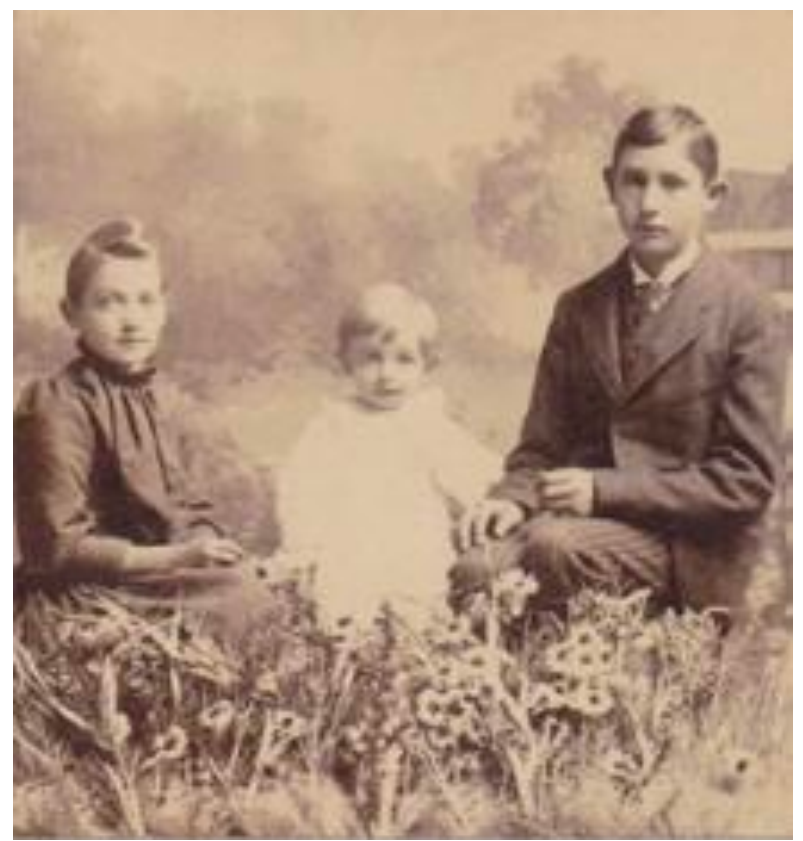

Figure 35: Photo of Victorian children. 


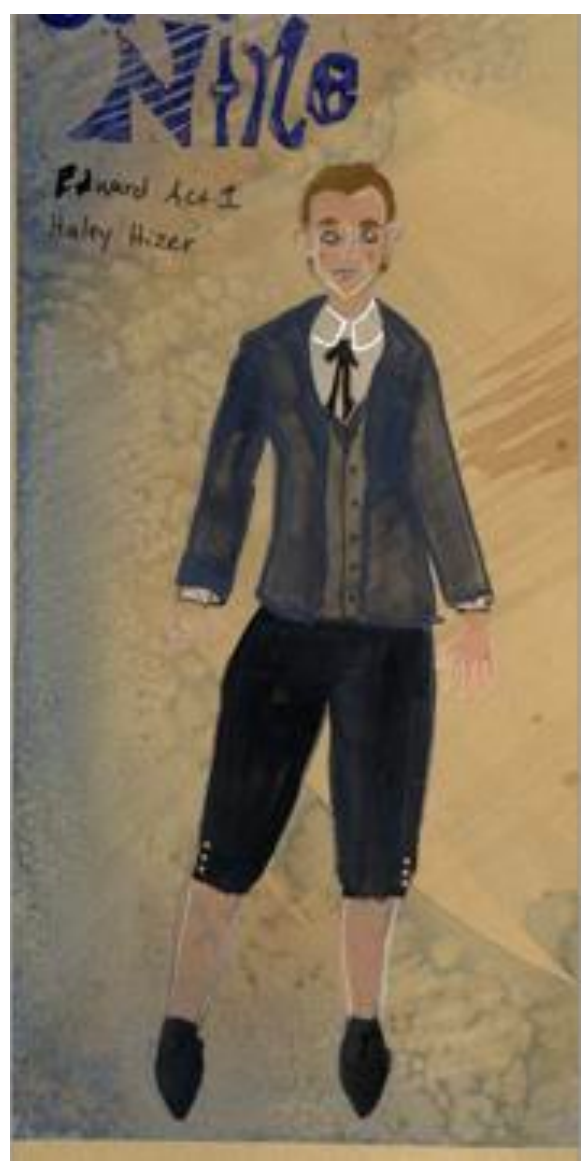

Figure 36: Rendering for Edward

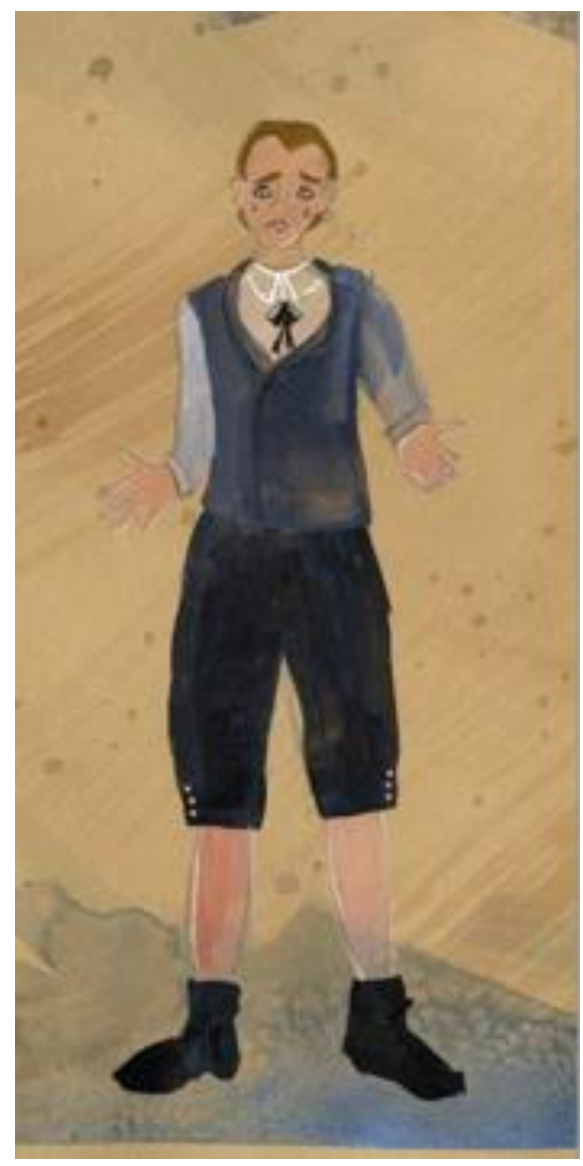

Figure 37: Rendering for Edward

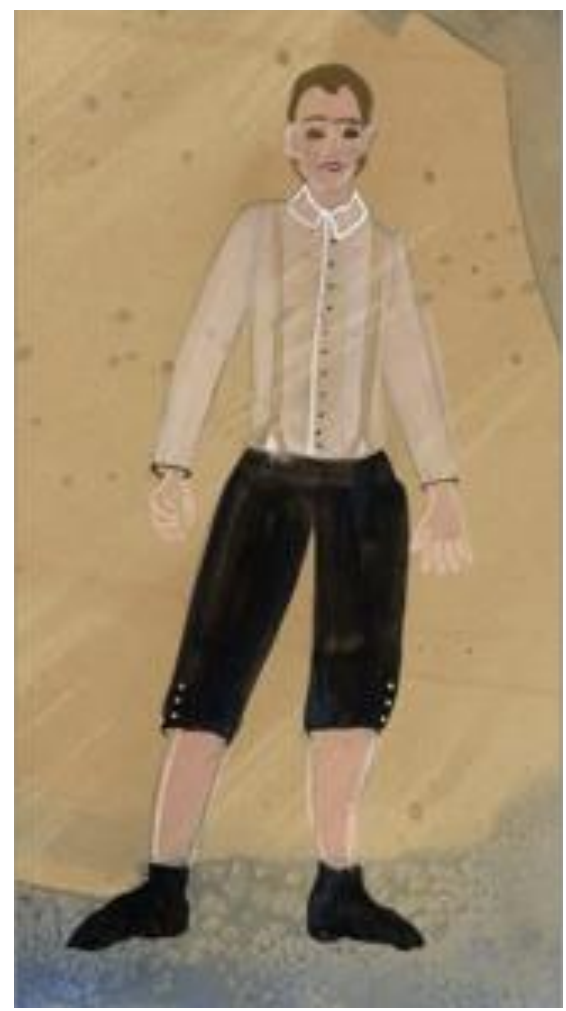

Figure 38: Rendering for Edward 
The character of Victoria in Act I is not an actor, but a doll. Her costumes were based on research images of Victorian children and their dolls, such as Figure 39. As a little girl, Victoria embodied the view of the time that children were to be seen and not heard. When seen at all, Victoria would be with Ellen the governess (Figure 40). Victoria had very little agency over her own life and is moved at the whims of others.

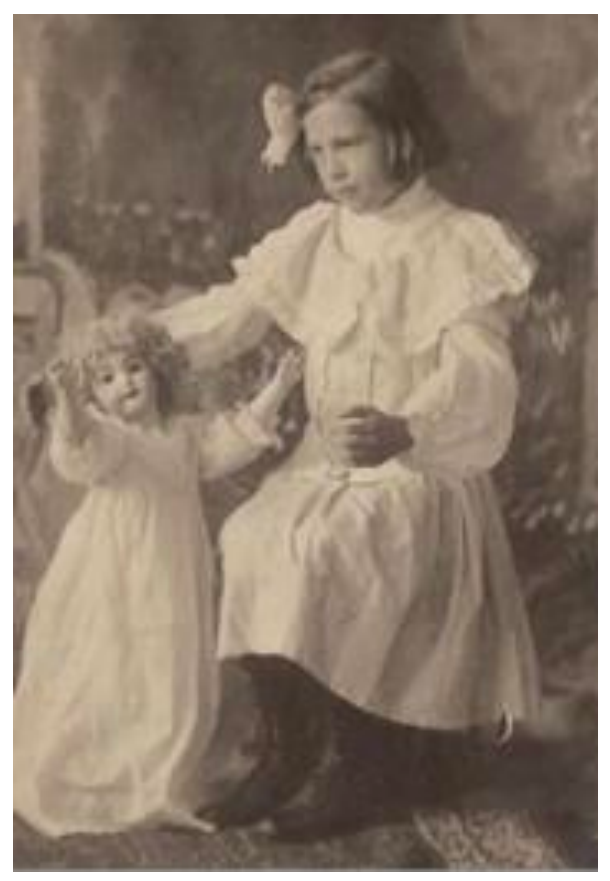

Figure 39: Research image, Victorian child with doll

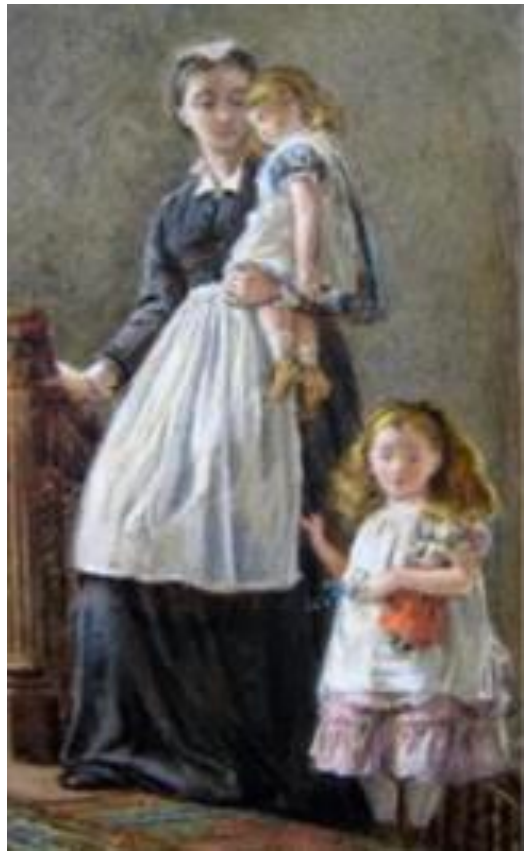

Figure 40: Victorian Children with governess

Maud, Betty's mother was woman out of her element in Africa. As a widow she is reliant on Clive's and Betty's relationship for her own stability. Her costumes reflect that she is not up to date with current styles, but instead wears dresses that are several years behind the times. This gives her a larger silhouette in comparison to Betty, Ellen, and Mrs. Saunders. Her costume is more of an 1860's day dress silhouette (Figure 41 and Figure 42). Maud wears one dress the majority of Act I (Figure 43) and changes for the final scene into a more formal look (Figure 44). 


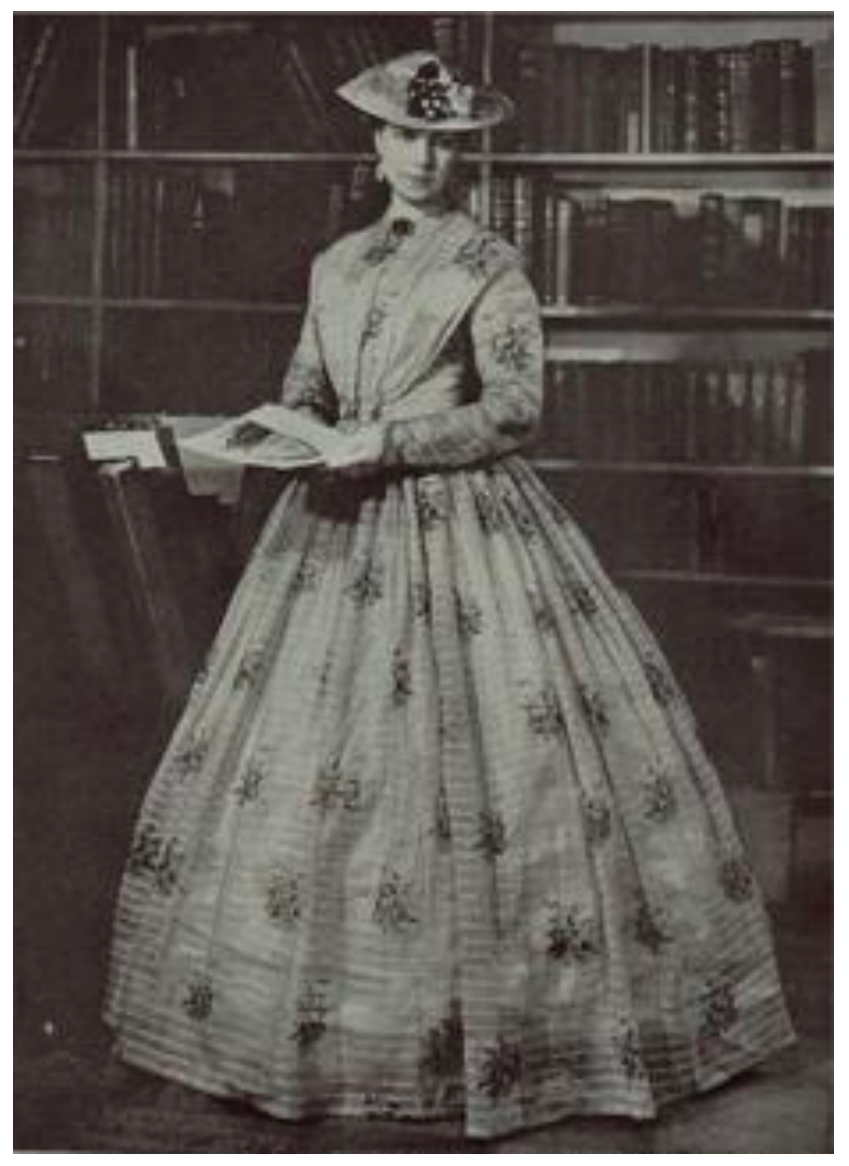

Figure 41: Research image for Maud

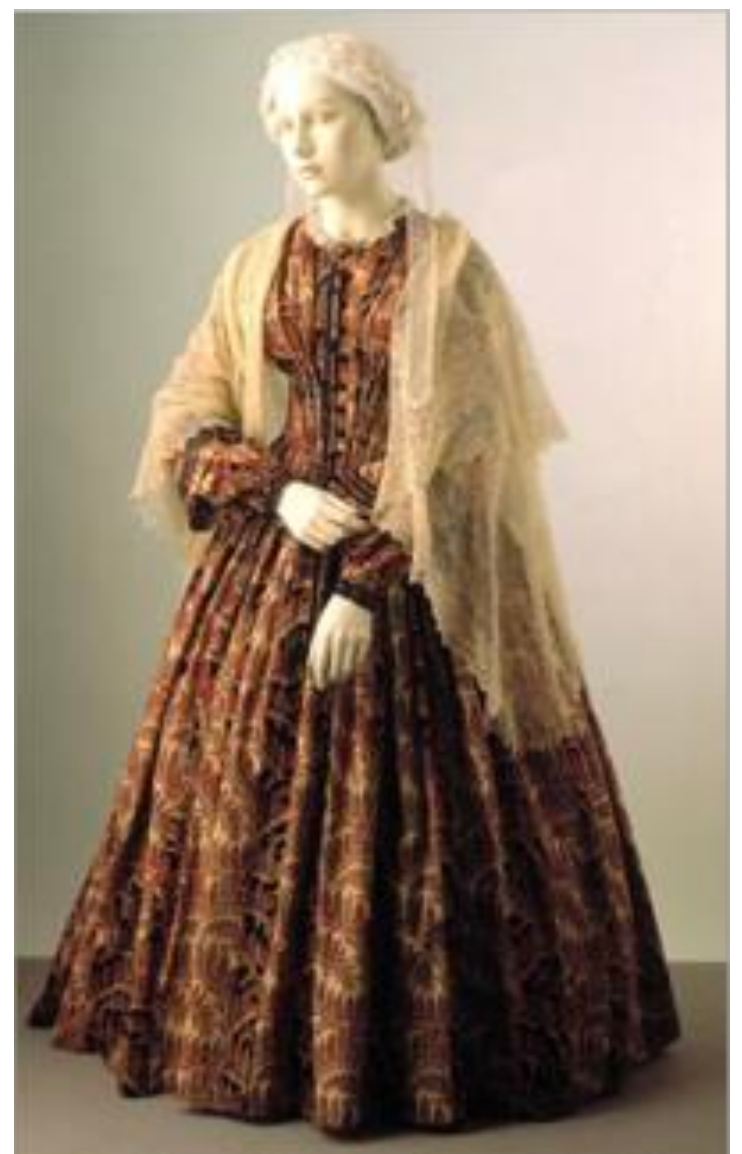

Figure 42: Research image for Maud 


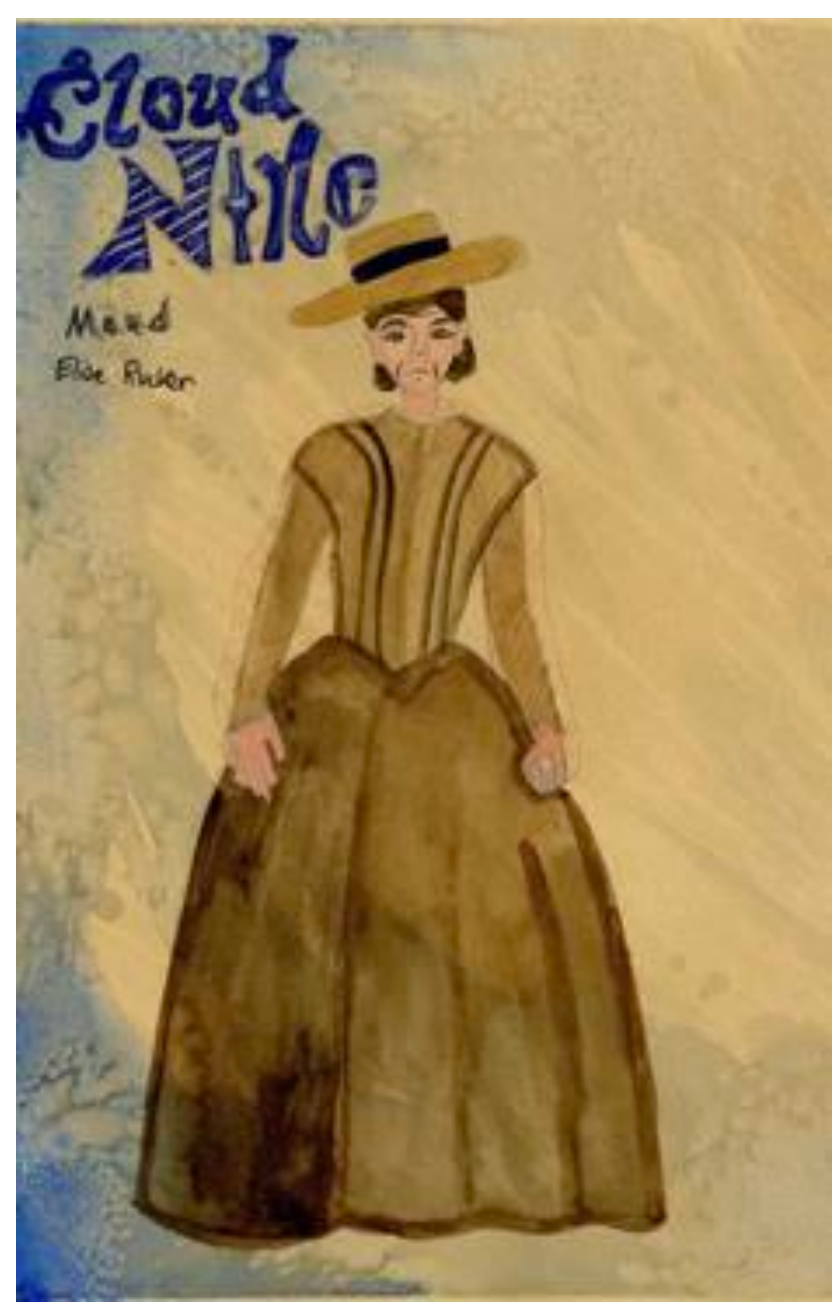

Figure 43: Rendering for Maud

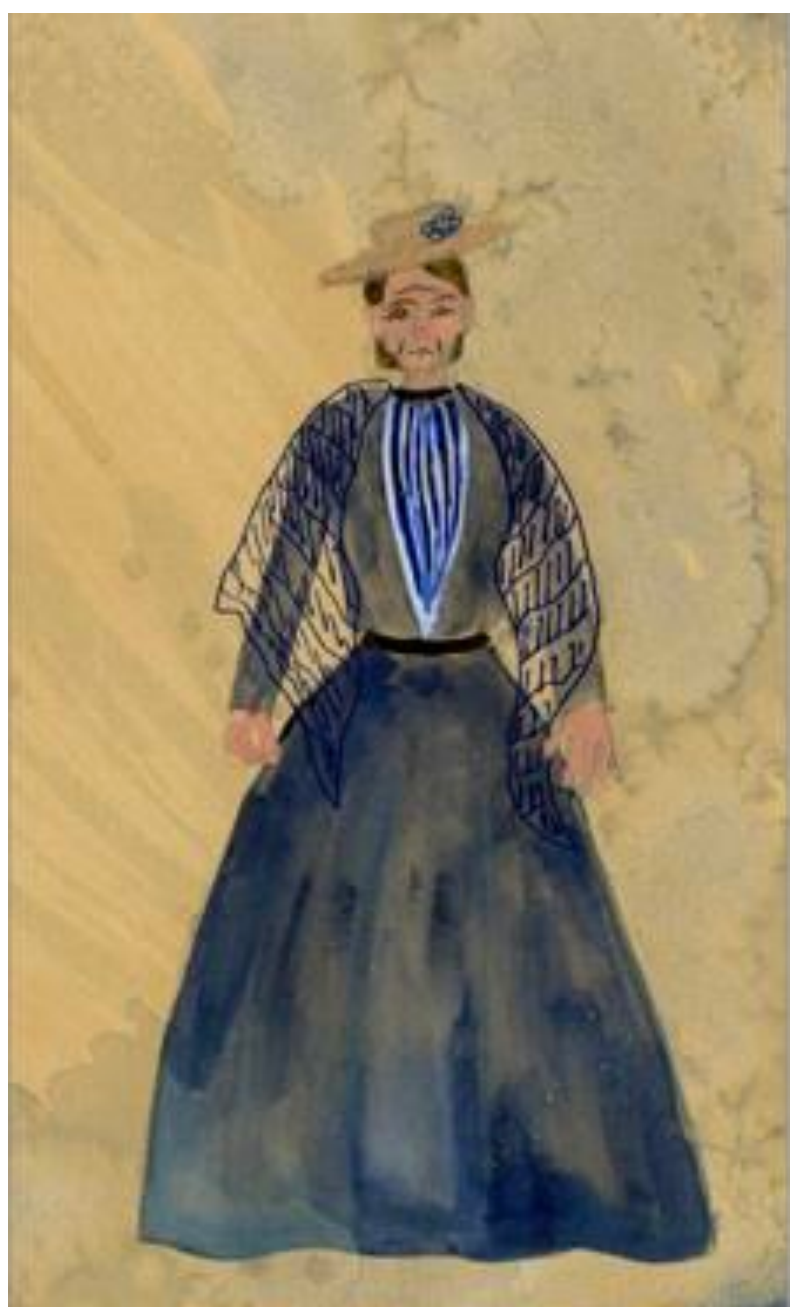

Figure 44: Rendering for Maud

Ellen was very simply dressed as she is not a member of the family. (Figure 45). She was only in Africa to be a governess to the children as pictured in Figure 46. Ellen's clothing reflected her social status and needed to be more functional than decorative. This resulted in her wearing items like an apron in order to protect her clothing from daily wear. 


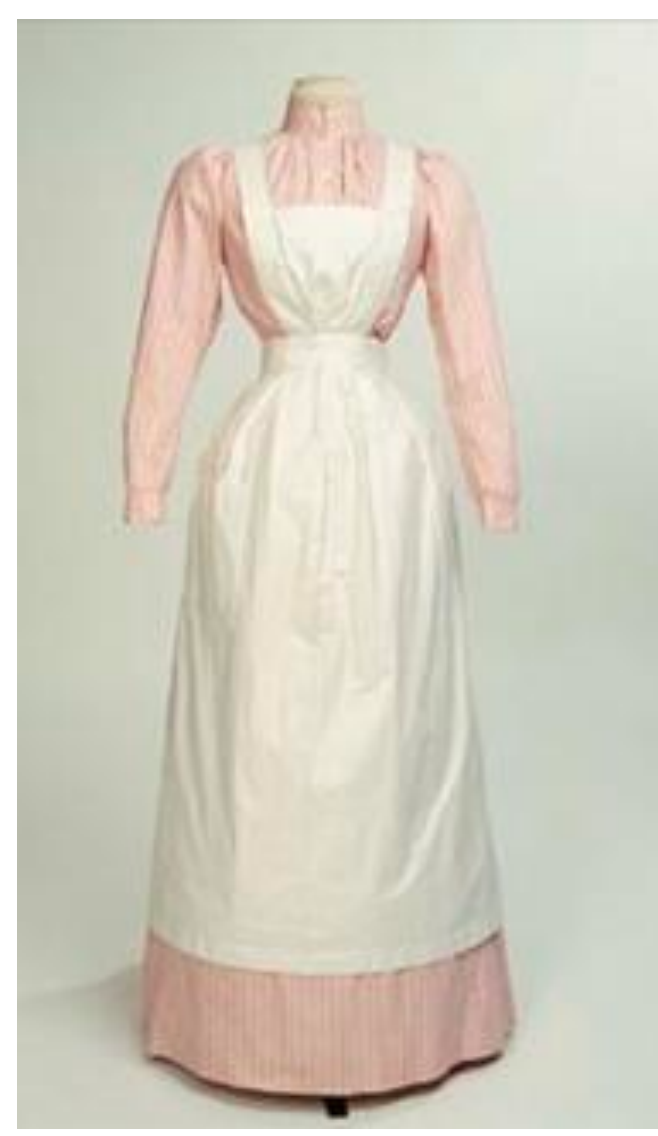

Figure 45: A research image for Ellen

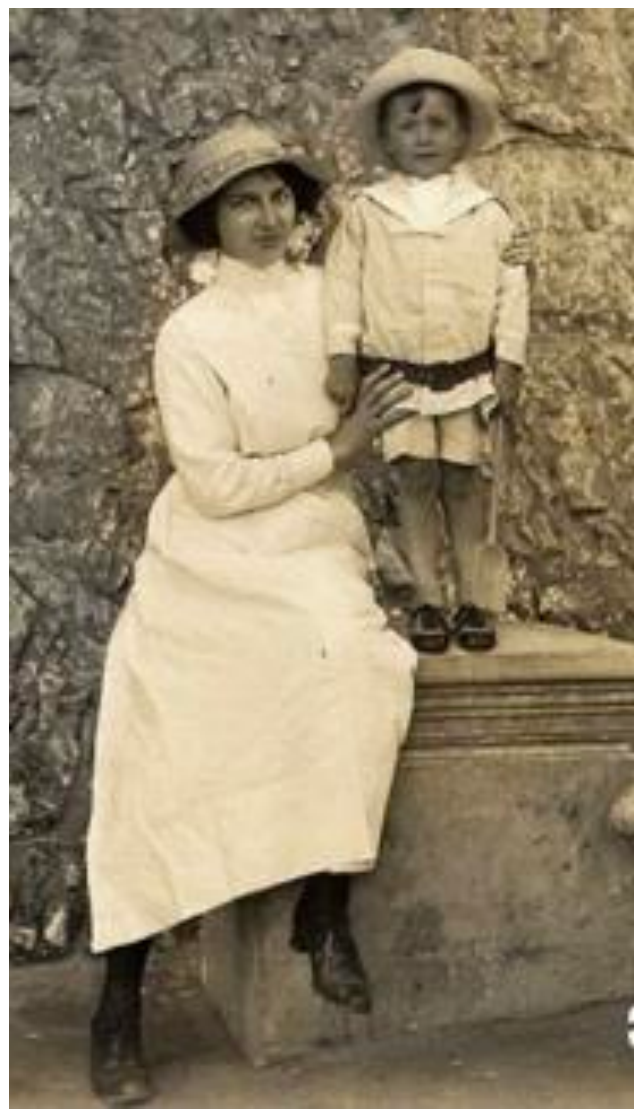

Figure 46: A research image for Ellen

The widow, Mrs. Saunders wore practical clothing and had more freedom than any of the other females in Act I. Visually this is seen in her wearing a blouse and skirt separates. While still feminine, it would be considered easier to wear than a full Victorian day dress (Figure 47 and Figure 48) and therefore, not appropriate. Clive also repeatedly compliments her “adventurous spirit". Visually, I interrupted and designed her costume this way to make Mrs. Saunders appear to be more rugged than Betty. Mrs. Saunders also entered in a wildly nontraditional, Victorian fashion by telling the family how she ran away from her home in the middle of night, grabbing what she could and exiting through the window. 


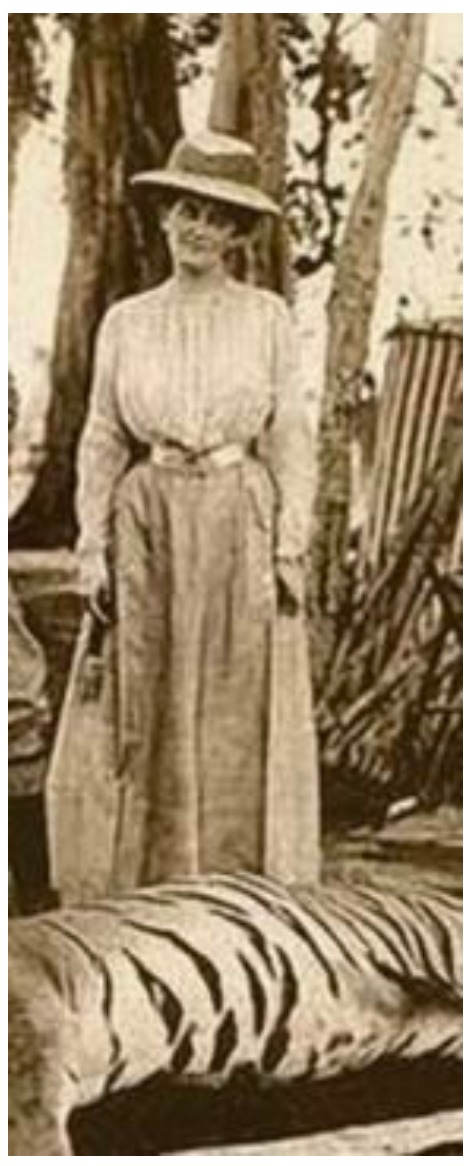

Figure 47: Research image for Caroline Saunders

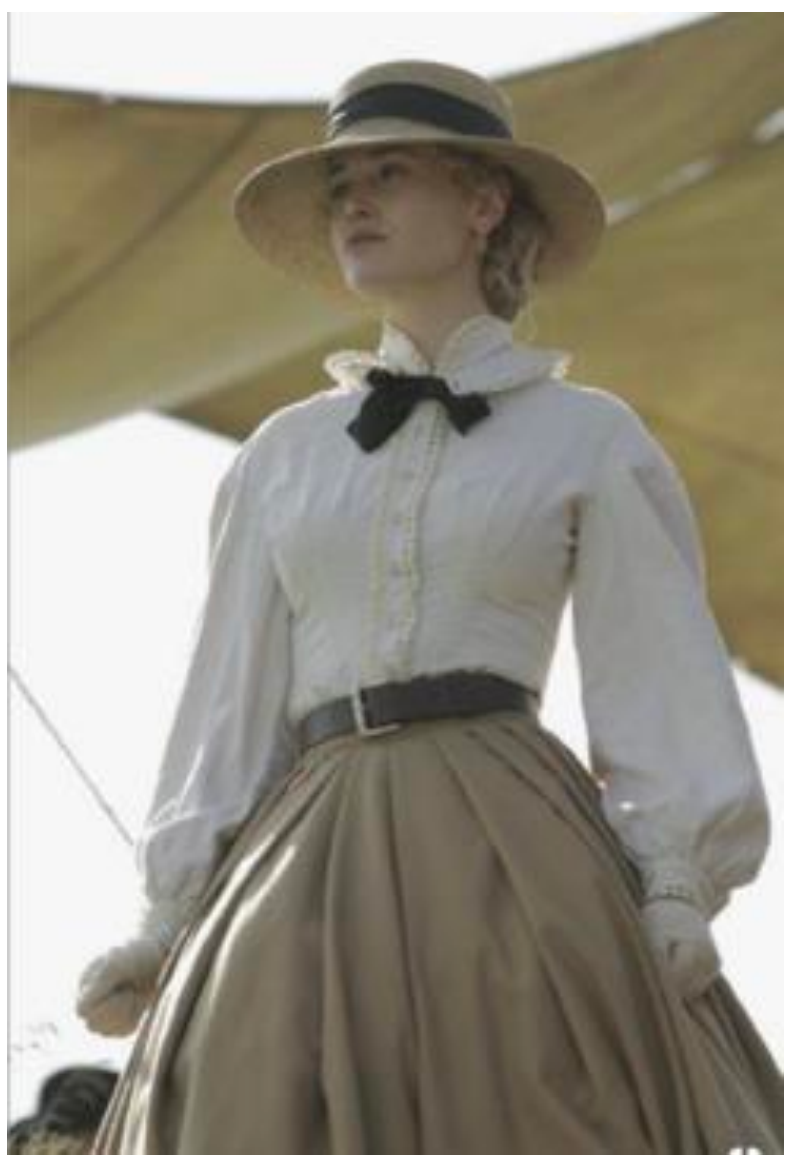

Figure 48: Research image for Caroline Saunders

For the final designs of Mrs. Saunders and Ellen, I had them sharing a skirt and changing their blouse and accessories to become alternate characters. They wore the same skirt for the majority of Act I, both changing for the final wedding scene into a lighter peach skirt. Mrs. Saunders started the show wearing her husband's military jacket (Figure 49). After removing the jacket (Figure 50), She did not change until the wedding scene where she wore a more formal skirt (Figure 51). Ellen wore a different blouse from Mrs. Saunders in order to help differentiate the character (Figure 52 and Figure 53). In the wedding scene she also added more accessories such as a neck ruffle and a cascading veil (Figure 54). 


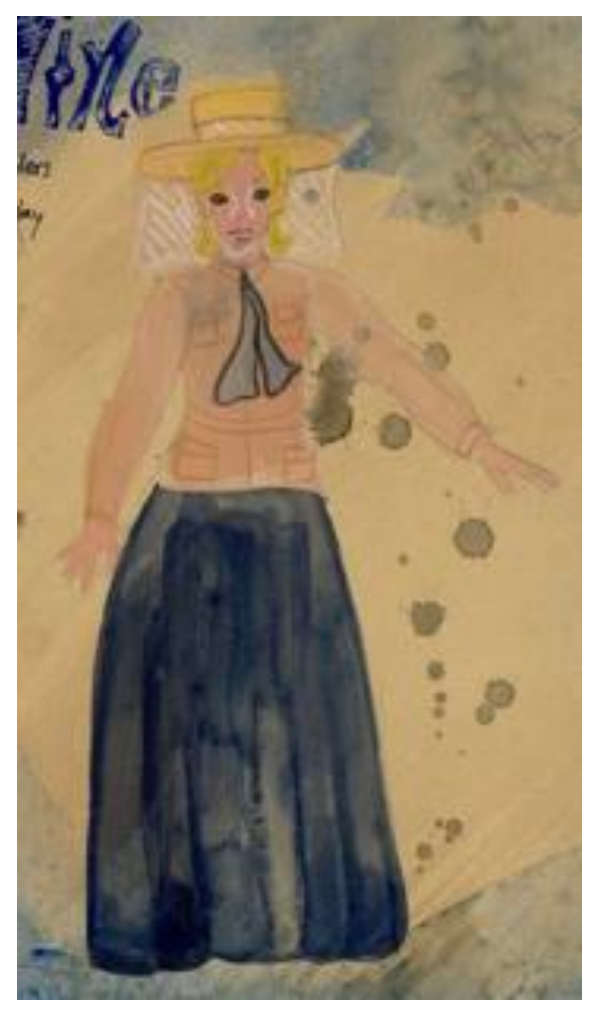

Figure 49: Rendering for Mrs. Saunders

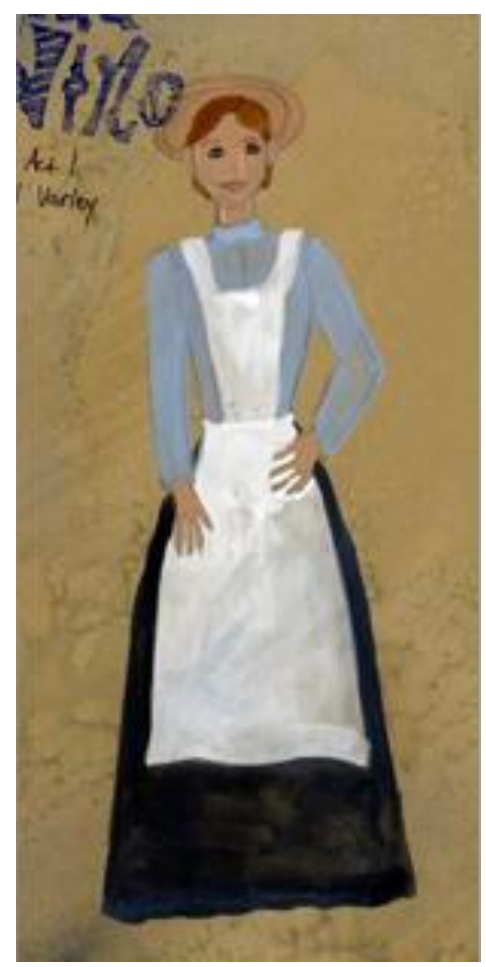

Figure 52: Rendering for Ellen

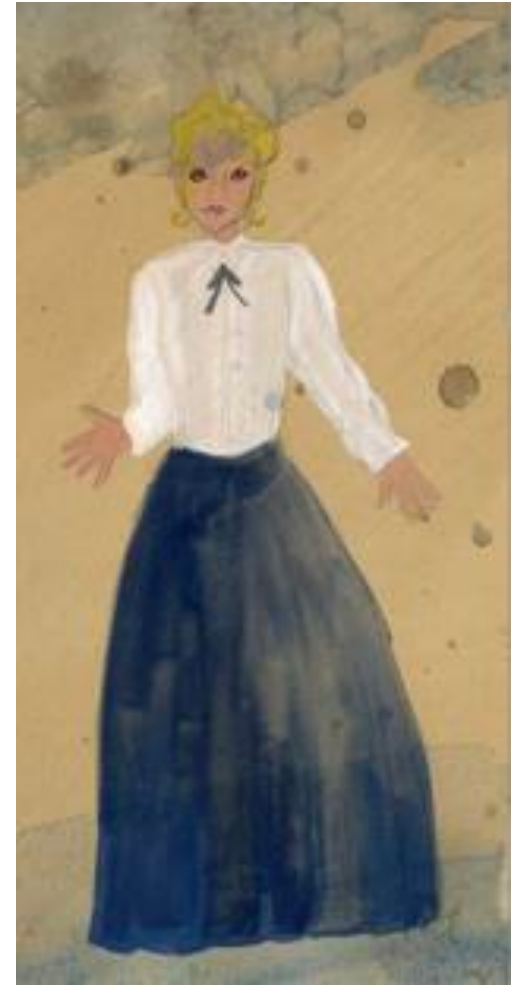

Figure 50: Rendering for Mrs. Saunders

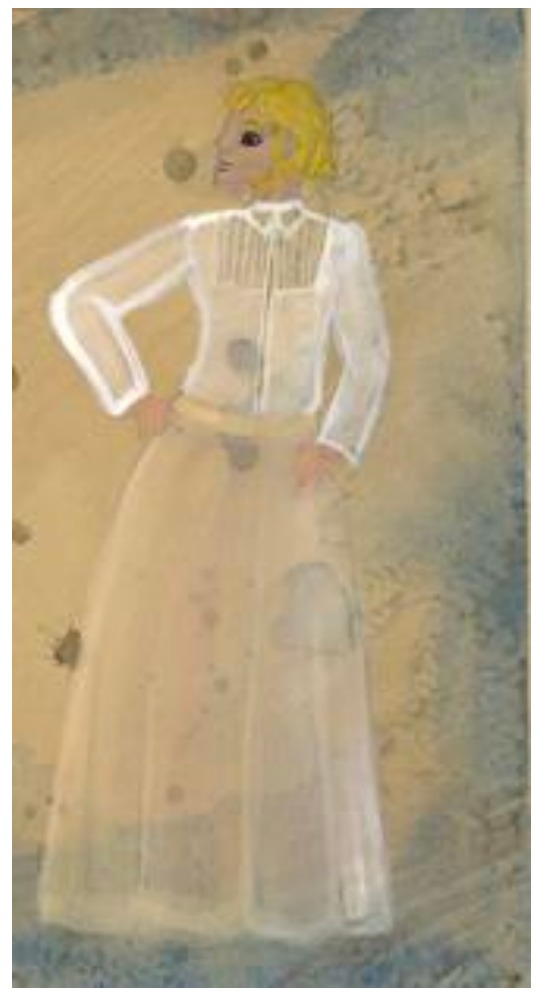

Figure 51: Rendering for Mrs. Saunders

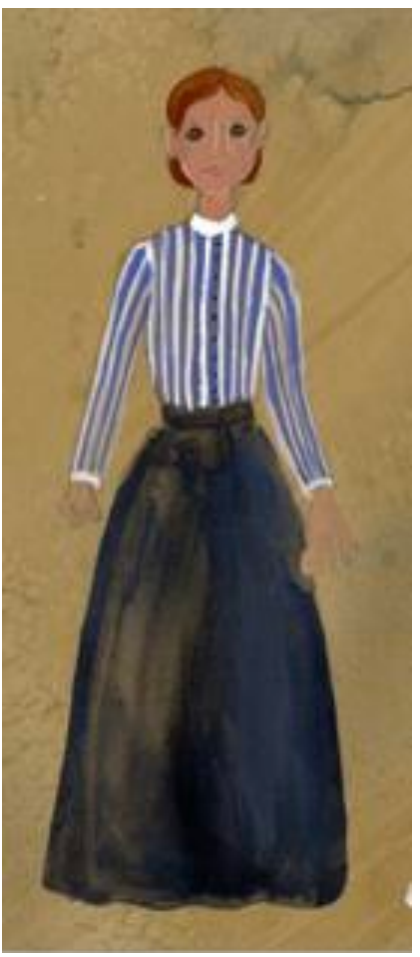

Figure 53: Rendering for Ellen

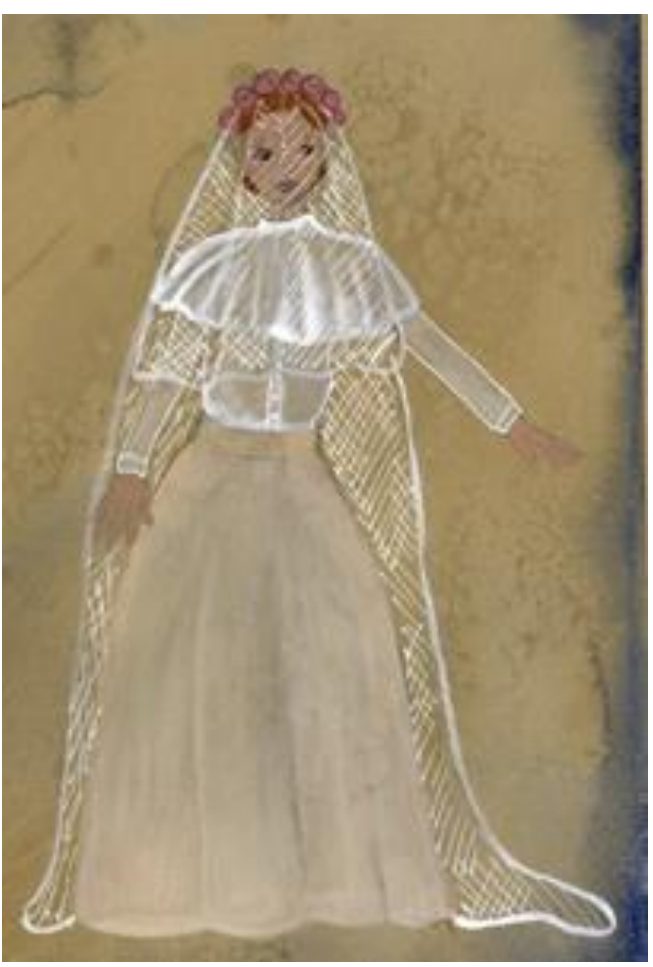

Figure 54: Rendering for Ellen 
The costume designs for Harry Bagley were inspired by a mixture of historical images of British explorers such as Henry Morton Stanley in Figure 55 and historical clothing such as the preserved British army uniform in Figure 56. During the original reading of the script, I pictured the character Clayton from the Disney version of Tarzan (Figure 57). Like the character Clayton, Harry is a dashingly handsome man but has alternative motives for wanting to leave England. He becomes an explorer in part because his sexual preferences. As he states to Clive, "where can I go except into the jungle to hide" (Churchill 46). As an explorer he has less opportunities to take care of his clothing making him less refined than the character of Clive (Figure 58- Figure 60). For the wedding scene at the end of Act I, I felt like Harry would not have his own clothes to wear; He is being forced into the wedding by Clive, while also being forced into Clive's old clothes for the occasion (Figure 61).

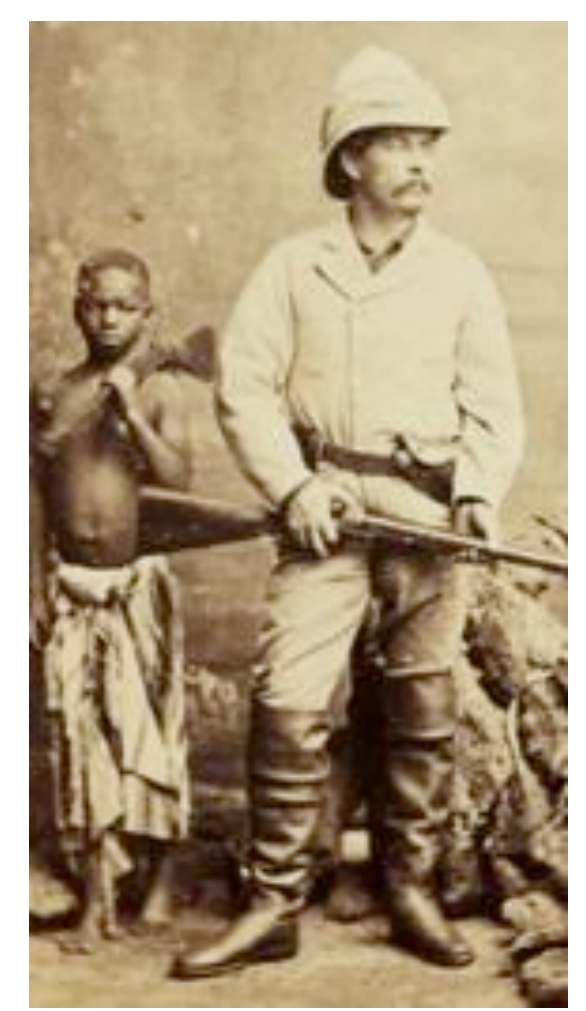

Figure 55: Henry Morton Stanley

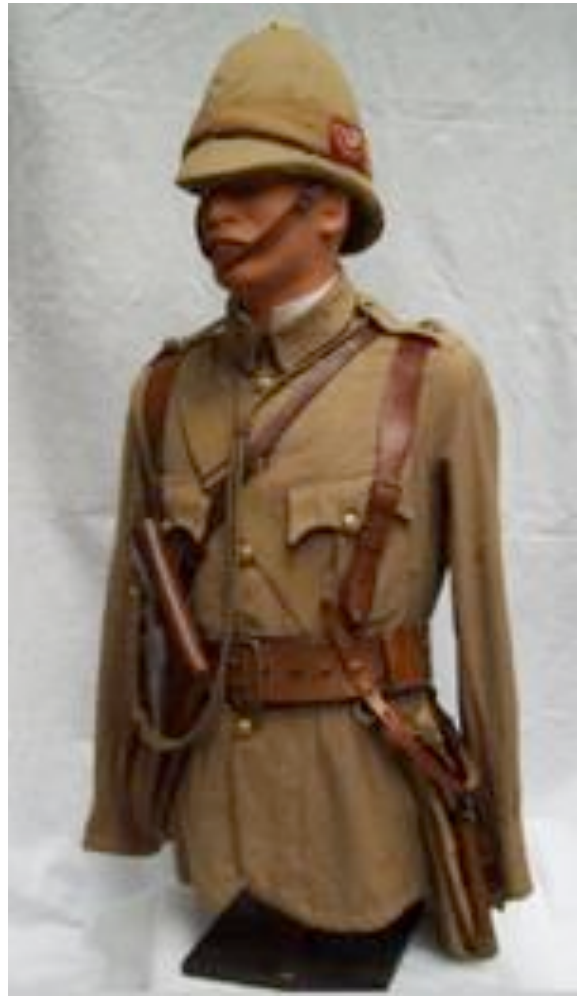

Figure 56: British army uniform 


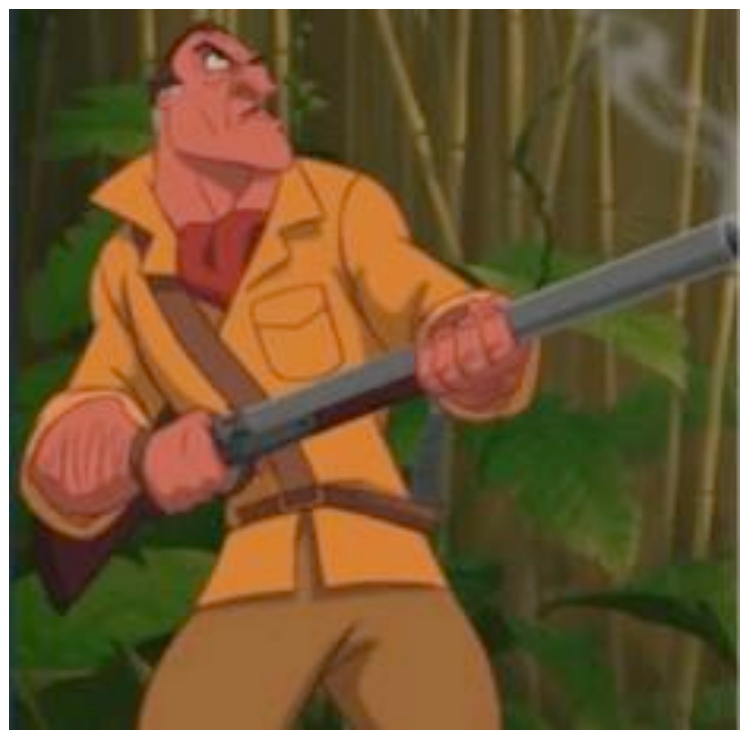

Figure 57: Clayton from Disney's Tarzan

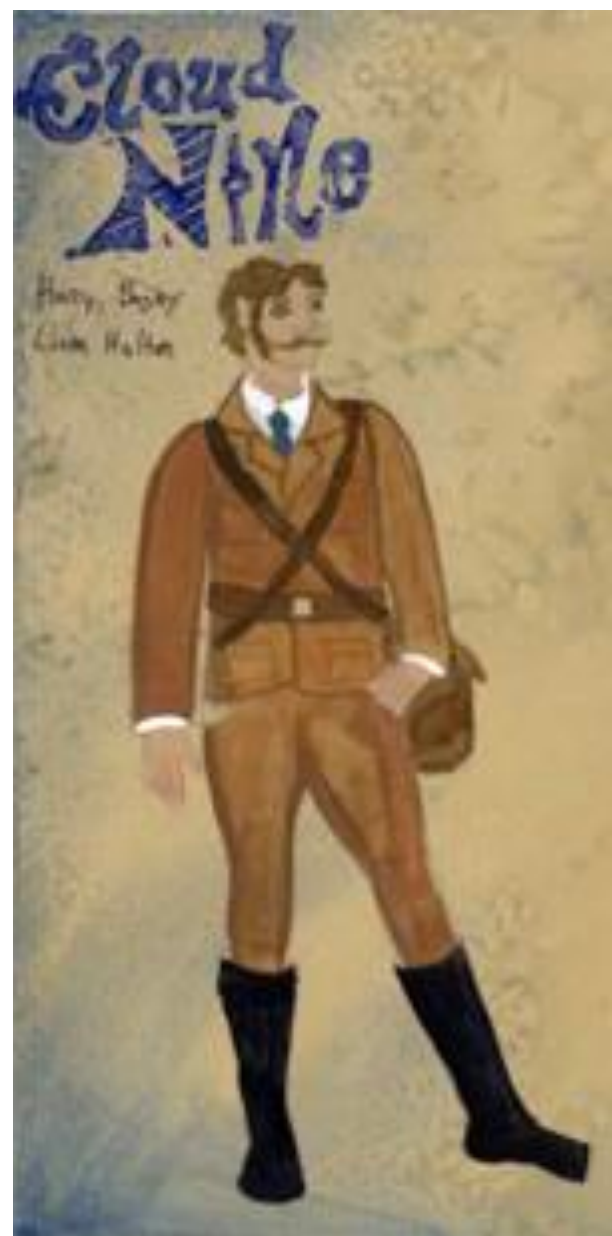

Figure 58: Rendering for Harry Bagley

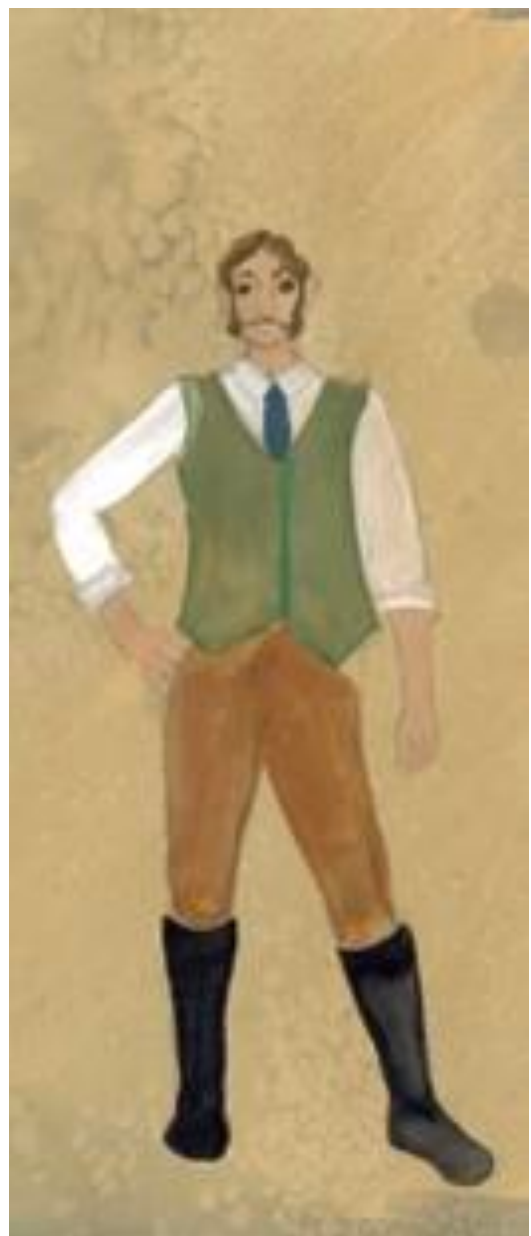

Figure 59: Rendering for Harry Bagley 


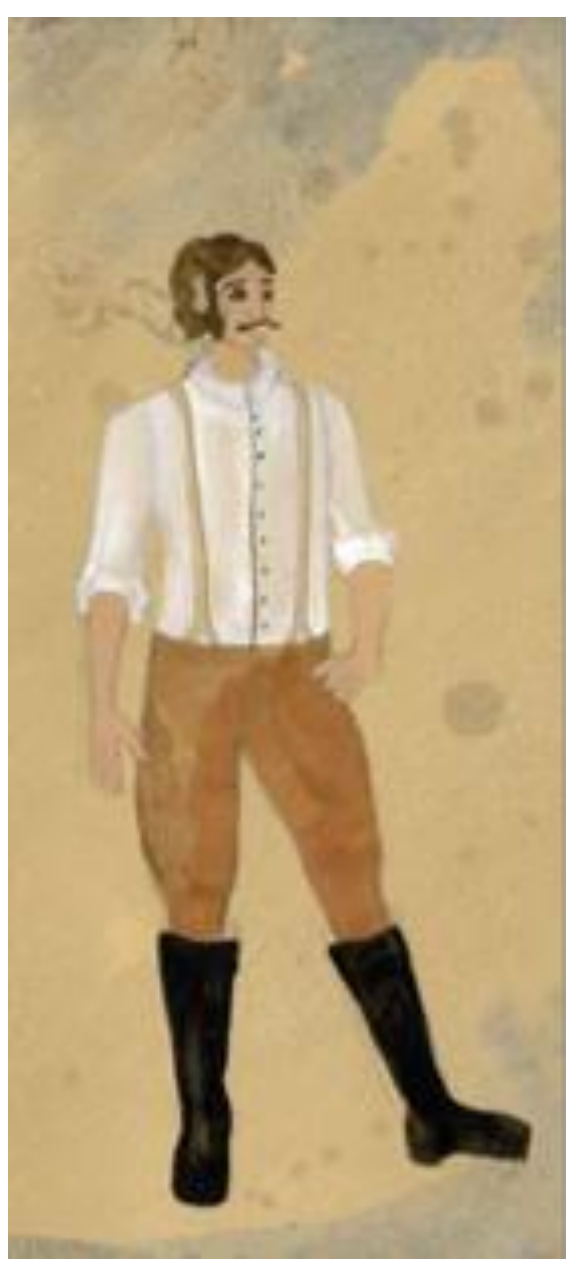

Figure 60: Rendering for Harry Bagley

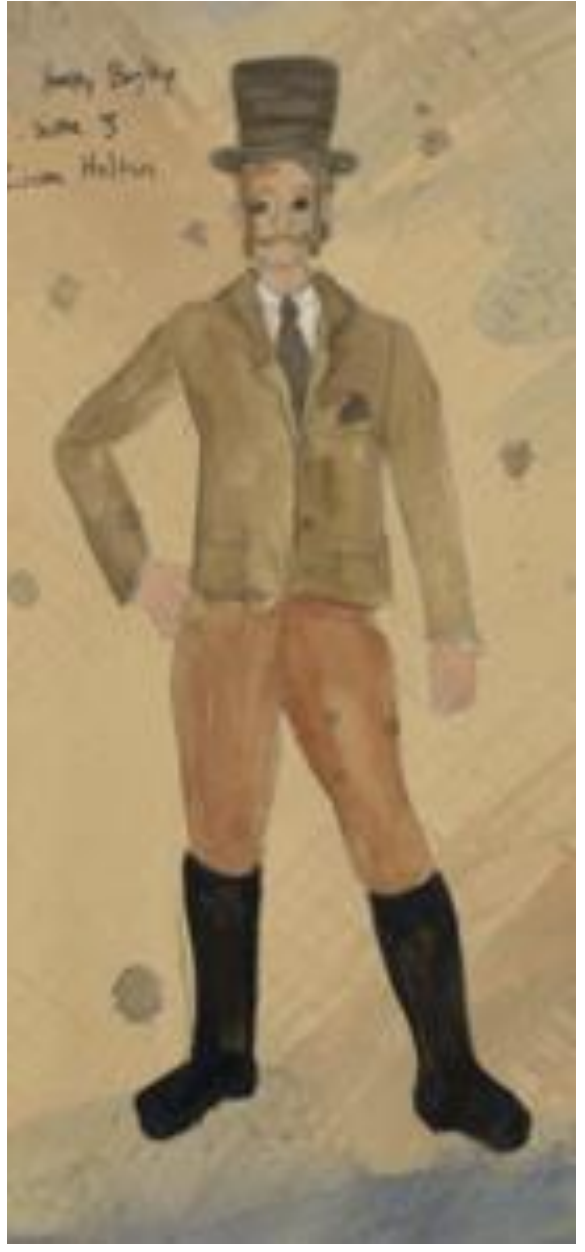

Figure 61: Rendering for Harry Bagley

From a costume design standpoint, Act II of Cloud 9 focused on bringing the characters into modern times through emphasizing their individual expression through fashion. Reading the script, I pictured who I thought each character could be walking the streets of a modem Los Angles or a New York City park. For each character, I came up with two different "look book" pages. While similar to each other, the second sheet for each character took their Act II character to a modern extreme (see Full "Look Book" pages in Appendix B). Adapting each character to 2018 required looking at their dialogue and choices in the script and deciding what fashion trends suited those characteristics. For contemporary research, I turned to the popular social 
media platform of Instagram for a jumpstart into creating my "Look Books." As a platform, "Instagram posts tend to be positively biased, as users engage in positive forms of selfpresentation and select positive aspects of their lives to display" (Trifiro).

For the character of Betty in 2018, I referenced images of fashionable modern women. Though twenty-five years have passed in-between acts for the characters, it is still assumed that Betty is a woman in her late 50's or early 60's. Being on her own and working for the first time in her life, I imagined that Betty would have a certain standard and style in clothing that she has been accustomed to her entire life. I used the term "Connecticut Mother" in my description of Betty when discussing her with the Director. In my experience, this referred to a woman of upper middle class to moderately high income who is more likely to shop for name brand clothing that is more fitted and tailored to her figure such as Figure 62. As a second option, I pictured Betty wearing fashionable ladies' suits. Furthermore, as a woman who is working for the first time in her life, Betty has embraced modern business working attire as in Figure 63.

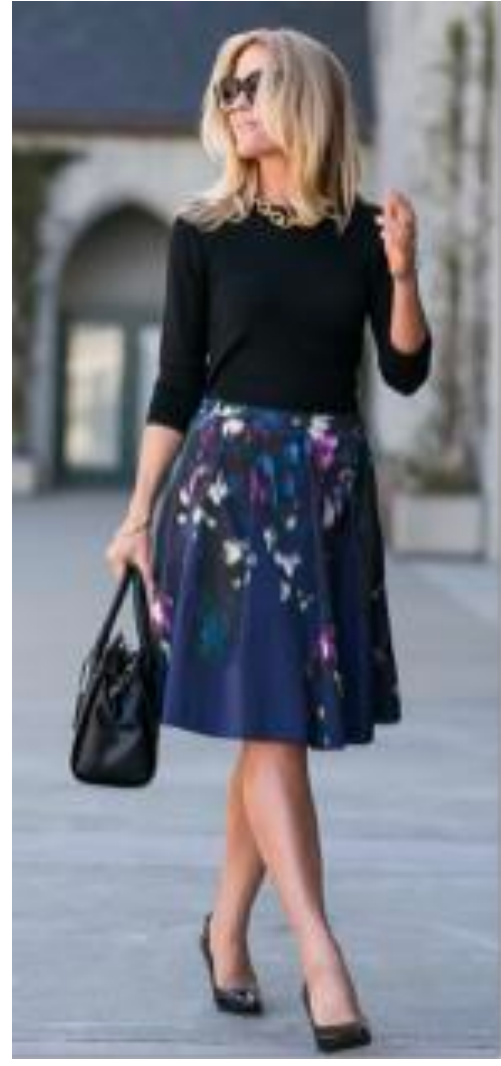

Figure 62: Research image for Betty in act II.

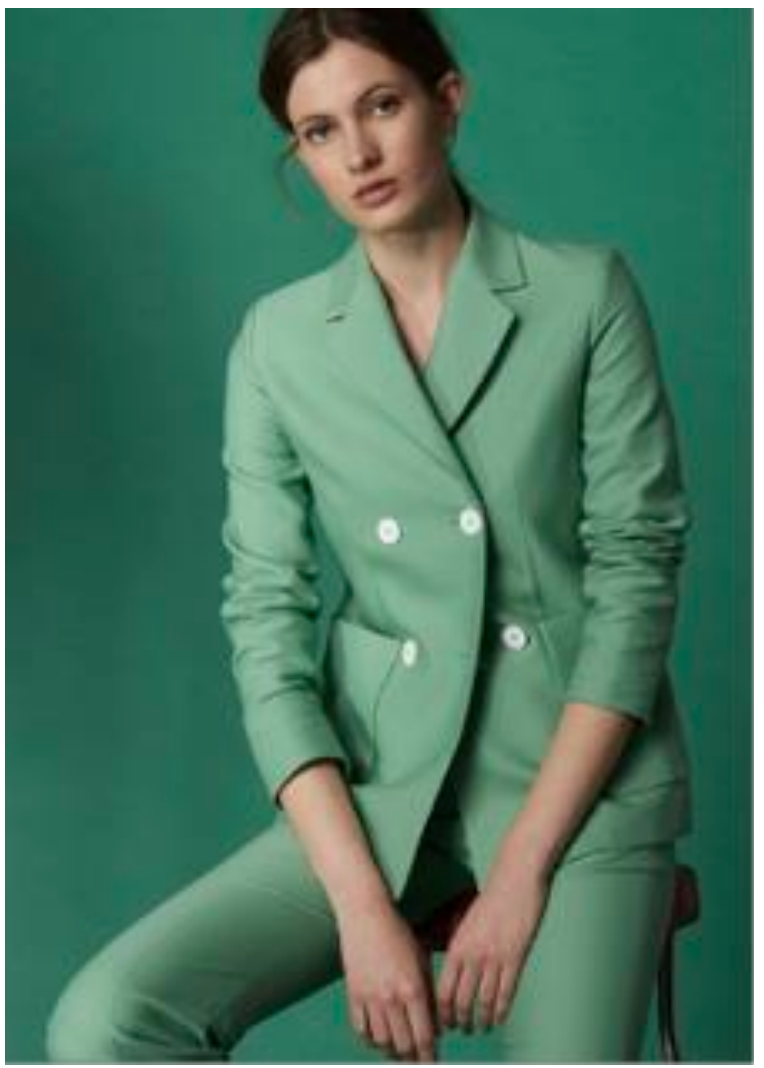

Figure 63: Modern woman's business suit. 
It was also important to note that Churchill decided the Act II Betty was played by the same actress as Maud in Act I. Betty is around the same age in Act II as Maud was in Act I. This casting choice highlights both the similarities and differences between the characters. Maud is highly critical of Betty in Act I, she strongly believes in traditional gender roles and she is happy for Betty's marriage to Clive, even though Betty herself wishes for something more. While Betty starts Act II critical of her children's life choices, she changes throughout the act to become more accepting, something that Maud was unable to do or given a chance to do by the playwright.

Betty's Act II costumes change through the act to reflect the season. She starts the act in a sweater and trench coat (Figure 64), and changes into a fitted dress (Figure 65 and Figure 66). By wearing modern feminine clothing Betty is exploring her new-found independence after separating from Clive, something Maud would never have supported.

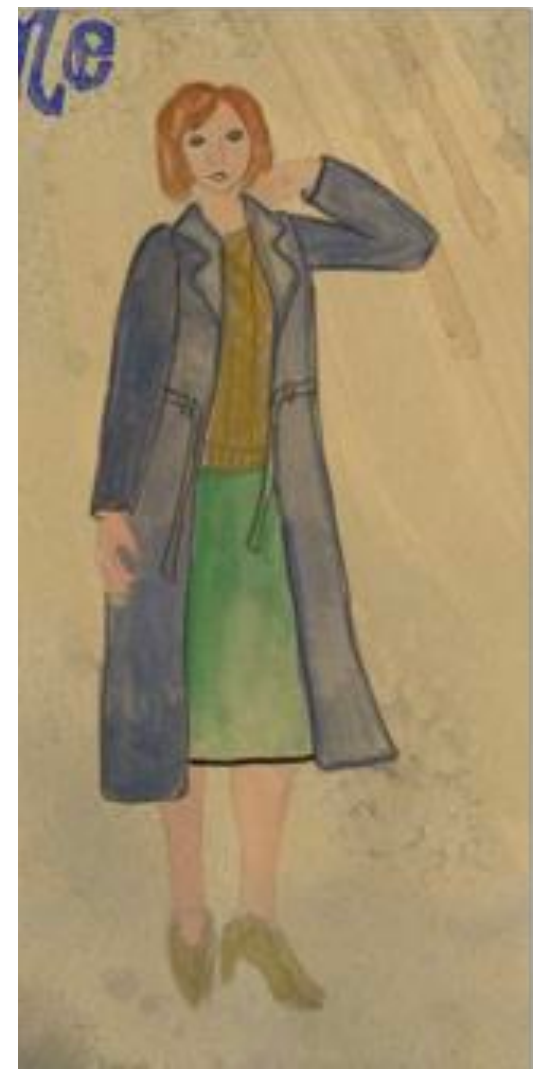

Figure 64: Betty act II

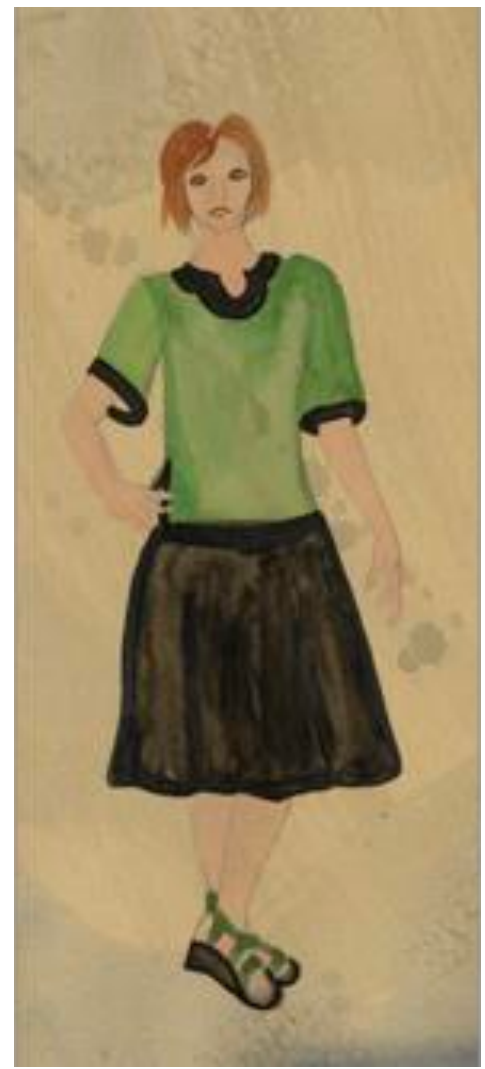

Figure 65: Betty act II

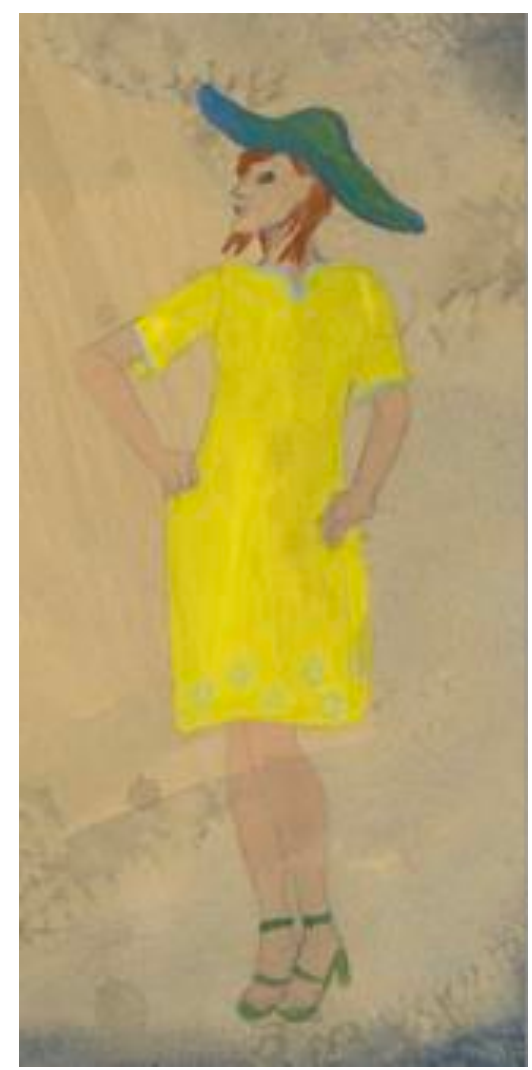

Figure 66: Betty act II 
The character Edward goes through a journey of self-acceptance through Act II that I tried to portray through his clothing a personal style. Edward in Act II is played by the actor who plays Betty in Act I. He is still growing into himself and his identity through Act II. Even though he is now portraying a male character, he values roles in his relationships that are generally viewed to be feminine, such a cooking, cleaning, and watching over children. In the beginning of Act II, Edward is working as a gardener in the park and does not wish to be exposed as homosexual by the character Lin. As the play moves forward and Edward comes more into his own skin, "so to speak" his clothing becomes a little more eccentric to visually show how he is willing to go against structured societal norms. As a visual through-line for his character, I was drawn to ocean and sea symbolism. To be "at sea", is a term for someone untethered to land and in a traditional sense. For Edward I saw this imagery to show in a subtle way his ability to remove himself from traditional values. He goes from someone who is pressured by societal norms to appear and act in a masculine manner to gradually accepting a more traditionally female role in the family and being a homemaker. Edward's inner transformation throughout the act is seen in his clothing becoming more colorful as the act progresses (Figures 67-69). He starts in scene one dressed for winter in a patterned jacket (Figure 70) and in scene two he is dressed to work in the park (Figure 71). In the "orgy scene", he is in contrasting patterns and a reflective sleeveless hoodie (Figure 72). The act ends with him in shorts and a sleeveless shirt, completing his transformation from fully covered to allowing parts of himself to be exposed (Figure 73). 


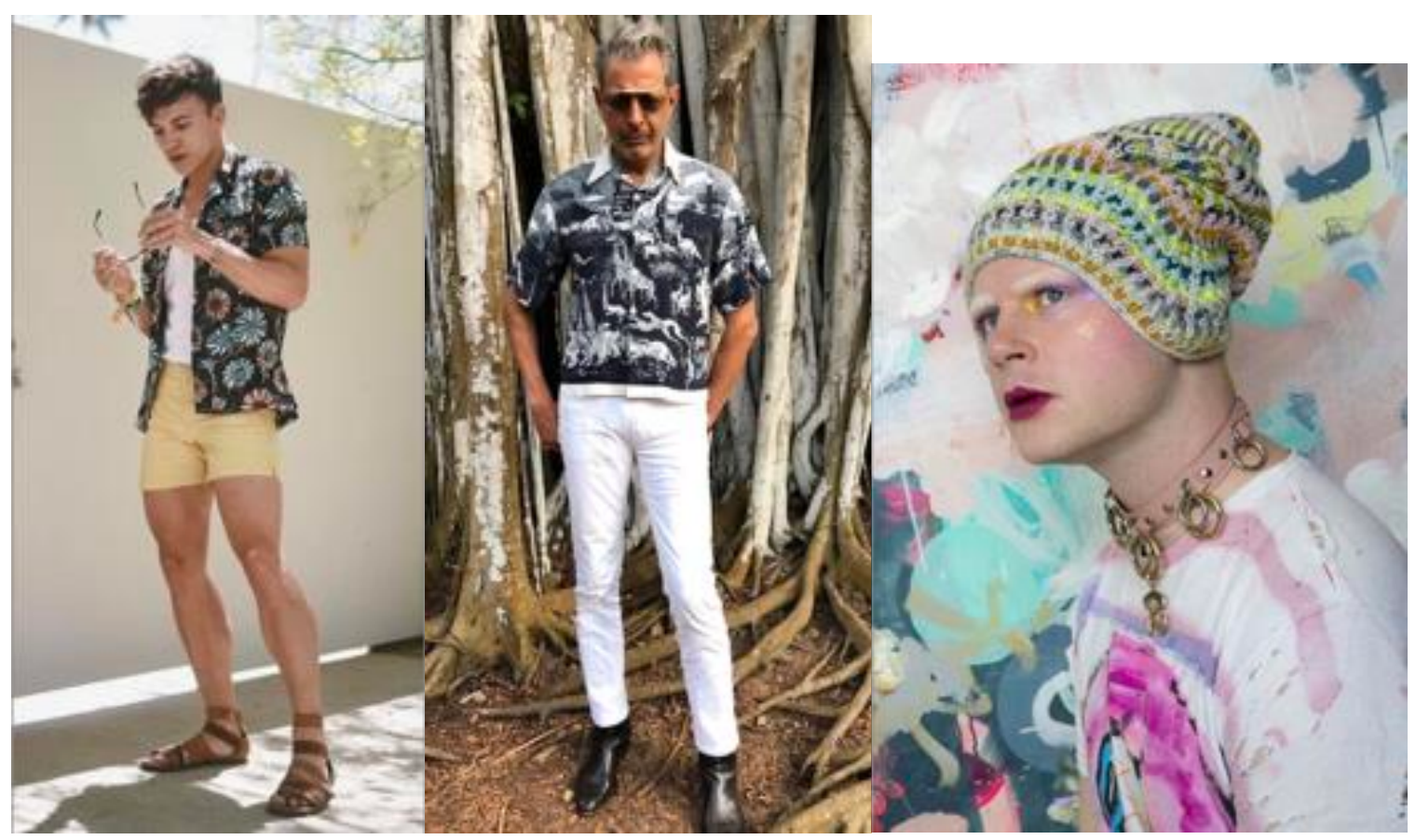

Figure 67: Research for Edward in Act II
Figure 68: Research for Edward in Act II
Figure 69: Research for Edward in Act II

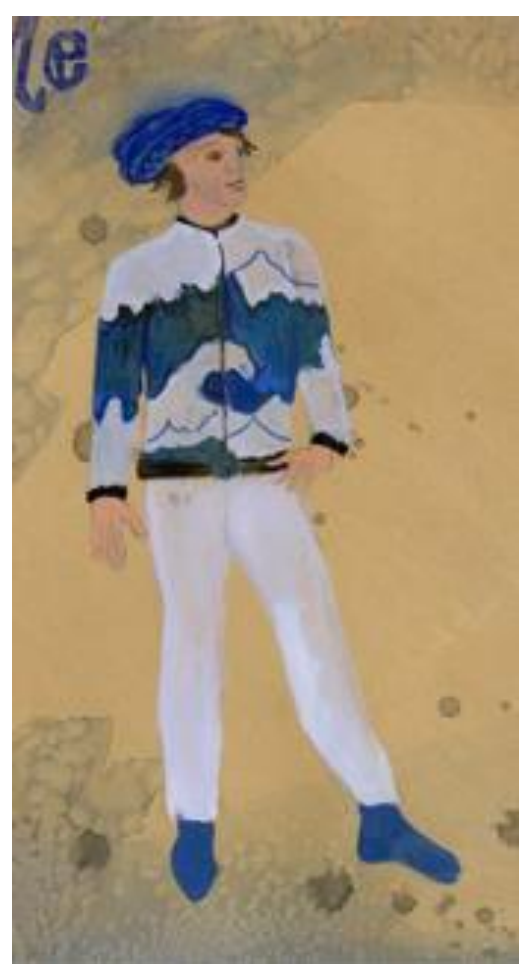

Figure 70: Edward Act II

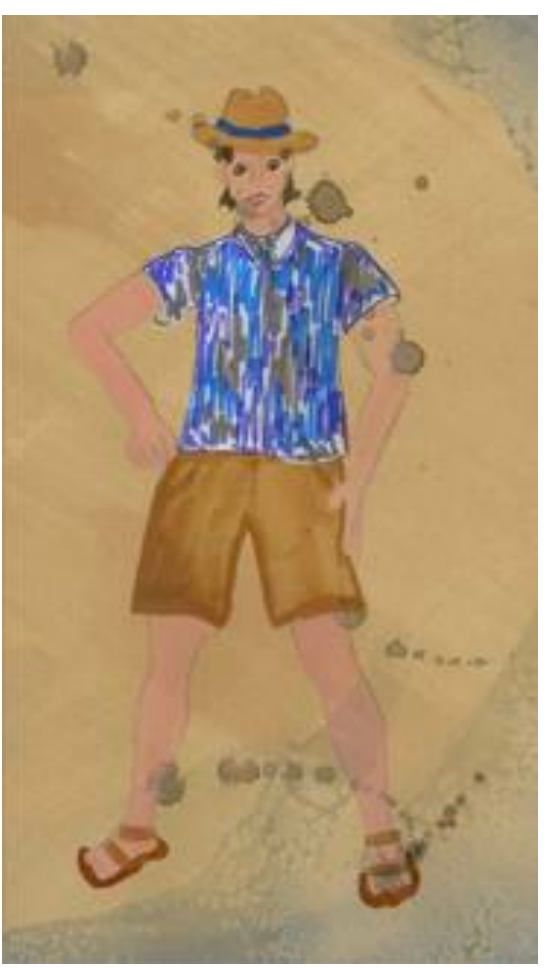

Figure 71: Edward Act II 


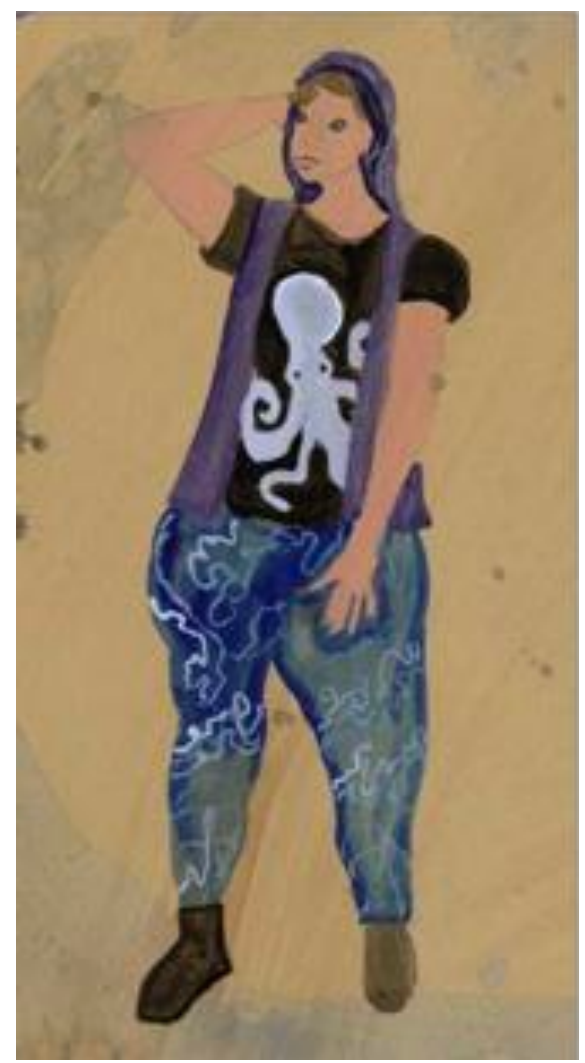

Figure 72: Edward Act II

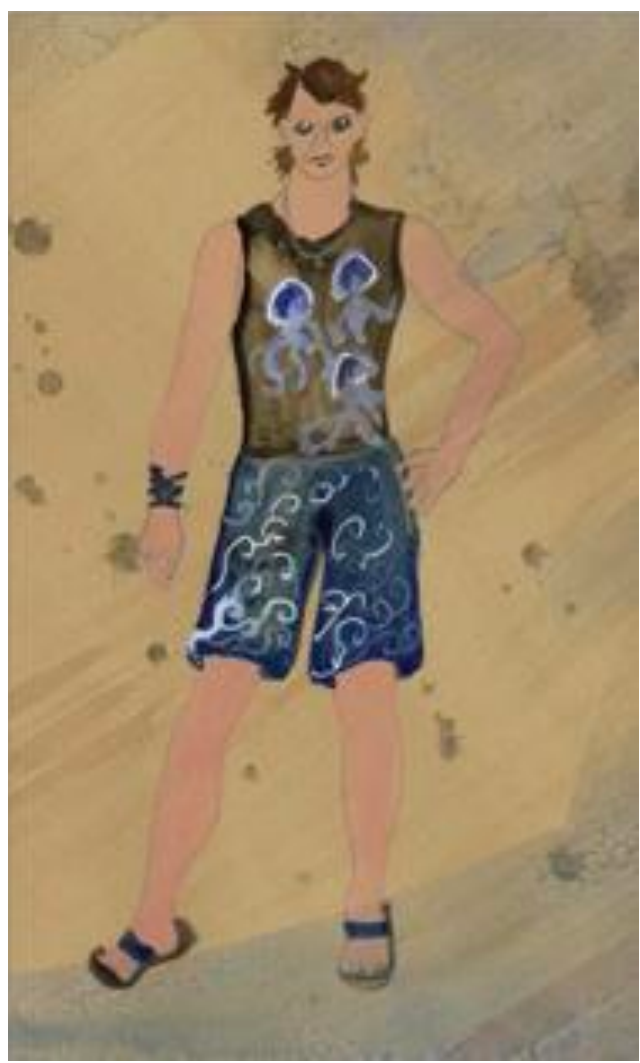

Figure 73: Edward Act II

Victoria is a doll in Act I of Cloud 9, in Act II of the show she comes into her own as an individual and has agency over her own body. She is played by the same actress as Edward in Act I. When thinking of Victoria in relation to modern times, I was drawn to popular figures such as Taylor Swift (Figure 74) and Miley Cyrus (Figure 75). These female icons are known to be controversial but are also strong females who have used their media presence to bring attention to the double standards women in the music industry in particular face. They embody the face of modern feminist who ride a thin line between exploiting the male gaze to get ahead and catering to it. Victoria is young, educated working mother who also exploring her sexuality. In viewing this and her dysfunctional relationship with her husband Martin, I tried to come up with a backstory of their relationship. In my design, I pictured Victoria as a more sexually liberal character, who may have become pregnant by mistake and made the choice to marry Martin after the fact. I was drawn to fashion imagery from events like that of "burning man" and "concert 
event culture" (Figure 76). This includes flowing, loose-fitting clothing in eccentric colors and patterns with a plethora of texture combinations such as fur and lace. As common imagery to integrate into her costumes, I was drawn to space and celestial designs. In relation to Edward whose imagery was the sea, the celestial sky felt complimentary. At times in the script Victoria seems a little "spacey" and absorbed in her own world. While reading in the park, she barely notices when the character Lin is trying to talk to her and later she loses her child thinking someone else is taking care of him. Even though she is a young mother, her child is not a central part of her life and is never seen on stage.

When reflecting upon these ideas in Victoria's costumes, she started Act II wearing a long skirt and bright blue fur coat (Figure 77). As the season became spring, she wore a bright orange skirt with a marble-textured, belly-shirt and a lace overlay (Figure 78). For the "orgy scene" in the park, I had her dressed up for a night on the town with shorts and a fish-scale sequin bodice (Figure 79). In the last scene, she wears shorts and an exposed bra with a mesh top and mesh skirt (Figure 80).

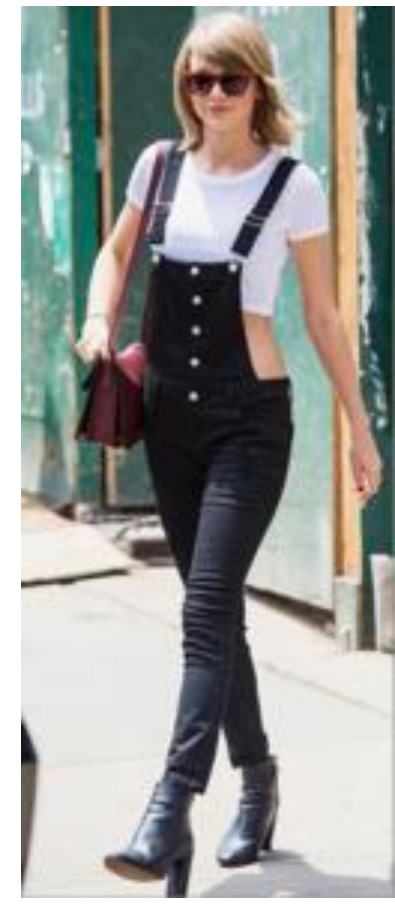

Figure 74: Taylor

Swift research image for Victoria Act II

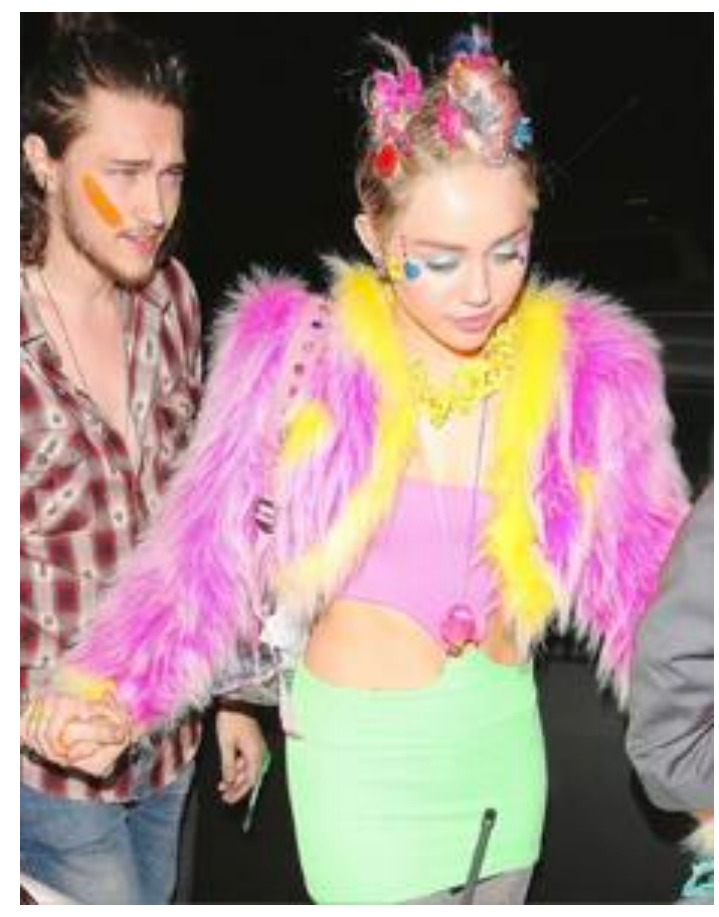

Figure 75: Miley Cyrus research image for Victoria Act II

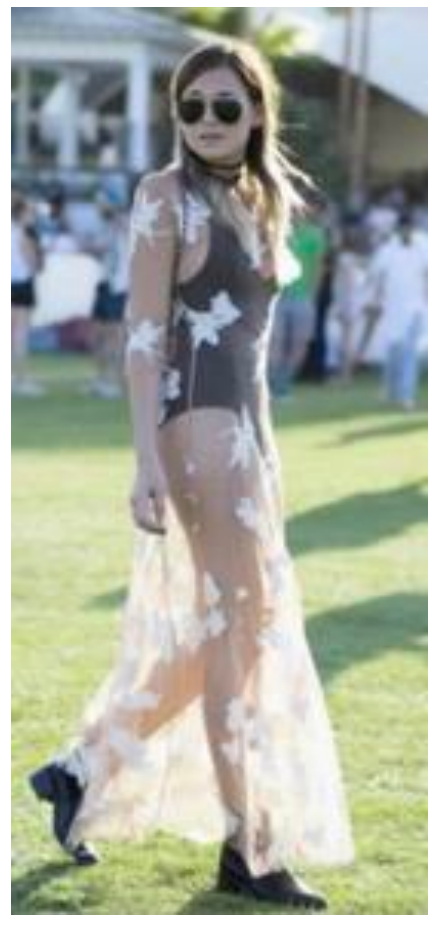

Figure 76: Research image for Victoria Act II 


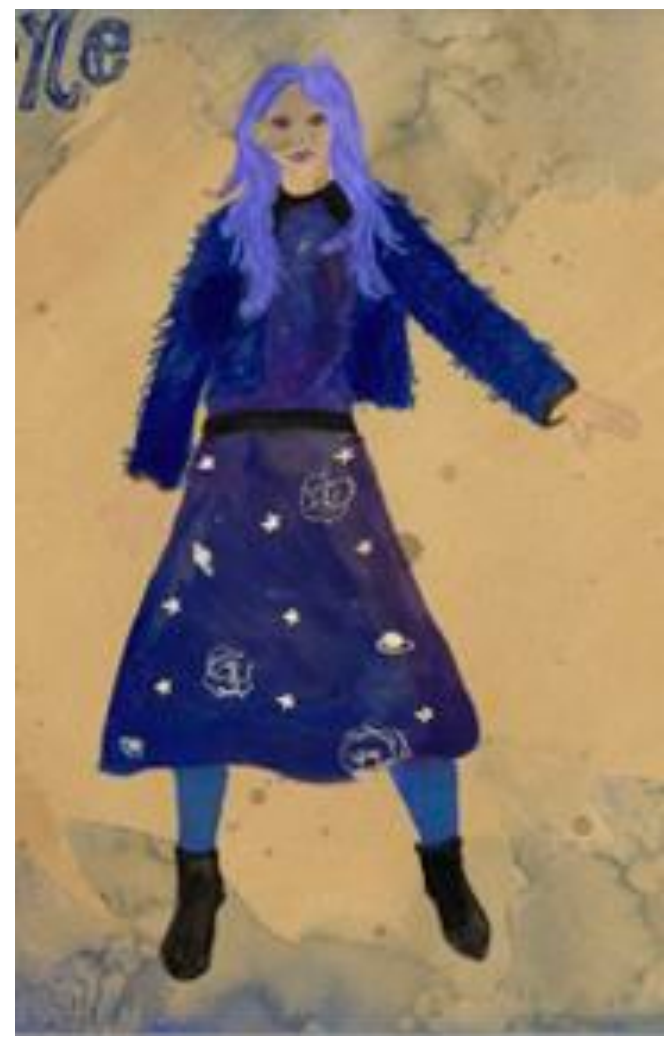

Figure 77: Design Victoria Act II

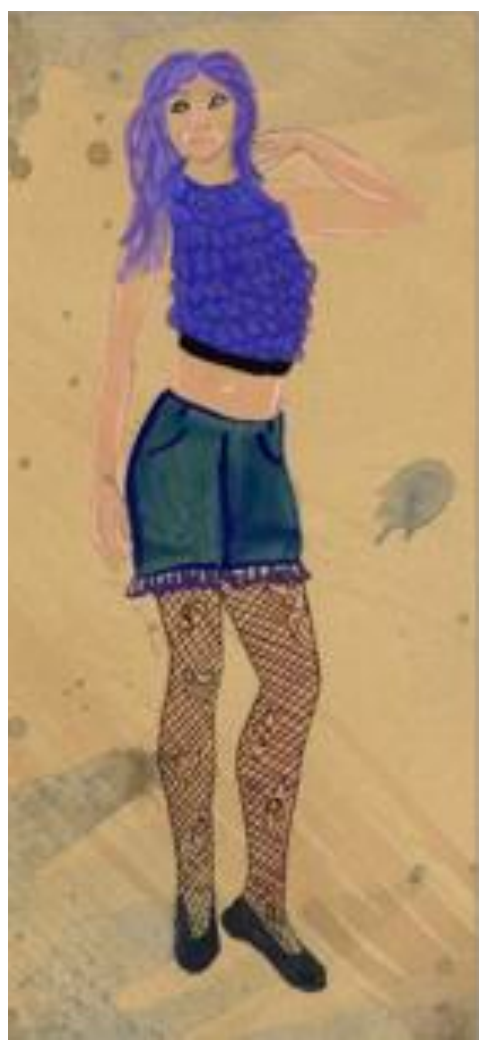

Figure 79: Design Victoria Act II

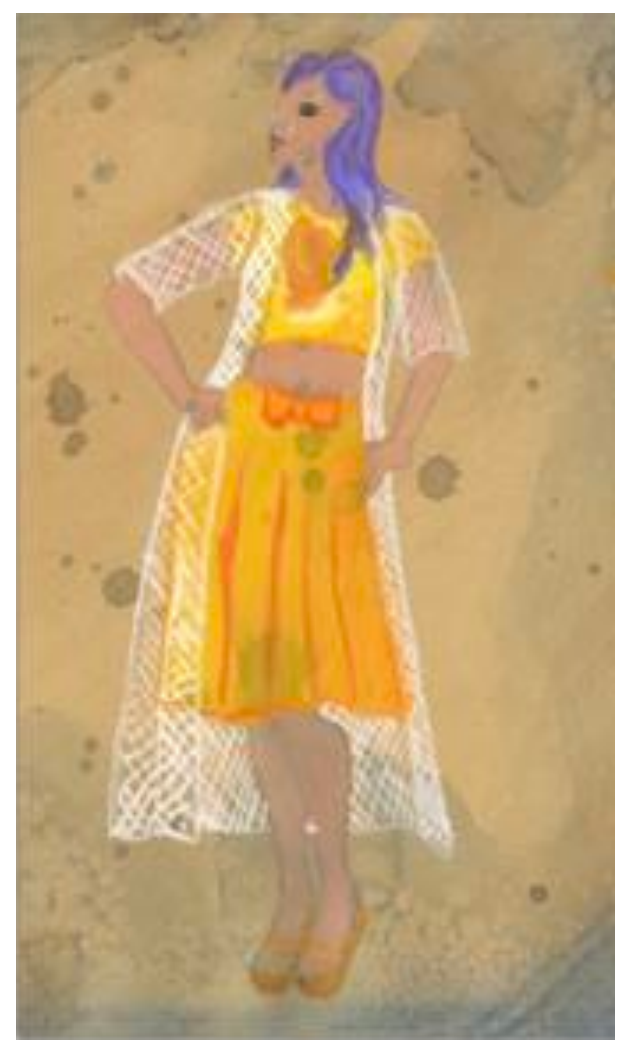

Figure 78: Design Victoria Act II

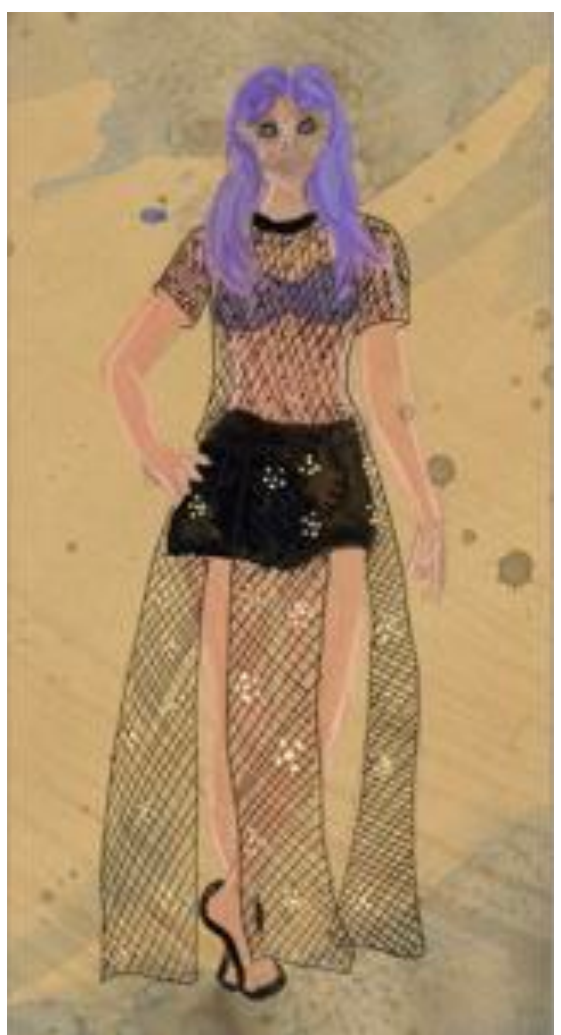

Figure 80: Design Victoria Act II 
Martin views himself as a modern feminist and is verbally obsessive about his performance in the bedroom. While doing character research, I imagined his relationship with Victoria being built around accidentally having a child together. In "millennial hookup culture" through dating apps like Tinder, I believed Martin would be described as a "player", a man who searches for casual sexual relations without too much commitment (Figure 81). A "player" "is not a dating style so much as a worldview that reeks of entitlement but is aghast at the prospect of putting in effort" (Massey). Martin labels himself as a feminist, yet falls short of being an ally to the movement. I was drawn to the t-shirt "This is what a feminist looks like" and the controversy surrounding it (Figure 82). Popular figures such a Benedict Cumberbatch were known to advertise this name brand shirt portraying the slogan, while at the same time the factories producing them were primarily "made by underpaid women in Mauritius — to the tune of 62 pence, or roughly one dollar, per hour" showing that "a progressive slogan doesn't necessarily make something progressive by osmosis" (Hyland). Martin seemed like the type of person to buy into a trend without fully comprehending the reality of it.

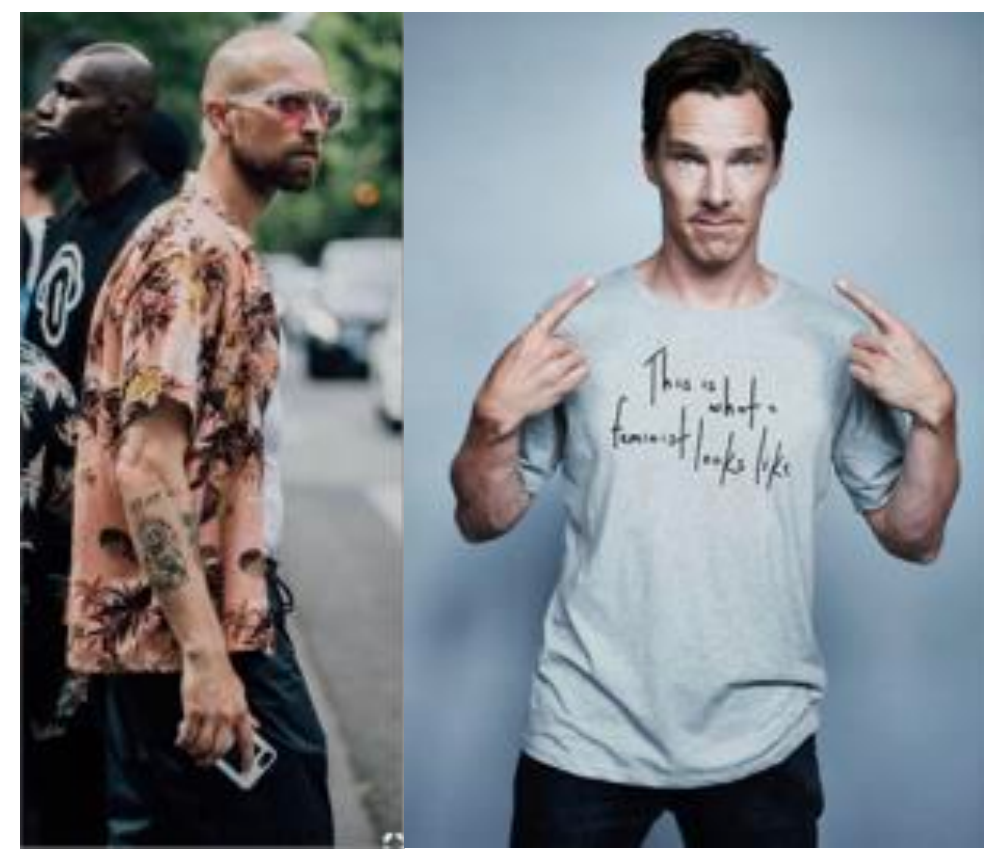

Figure 81: Research

Figure 82: Research for Martin for Martin 
After discussing these views of Martin with the Director, it was decided to move Martin away from this portrayal and to emphasize his intellectual qualities. For this I looked to pictures of modern "hipsters”. I had Martin starting in Act II, scene 2 wearing dark pants, suspenders, "tattoo" sleeves and a man bun (Figure 83). In the "orgy scene" in the park, I had him wearing striped pants and a plain t-shirt (Figure 84). As the play ends and he is in the park with Cathy and Edward, he does wear the "This is what a feminist looks like" t-shirt and a pair of shorts (Figure $85)$.

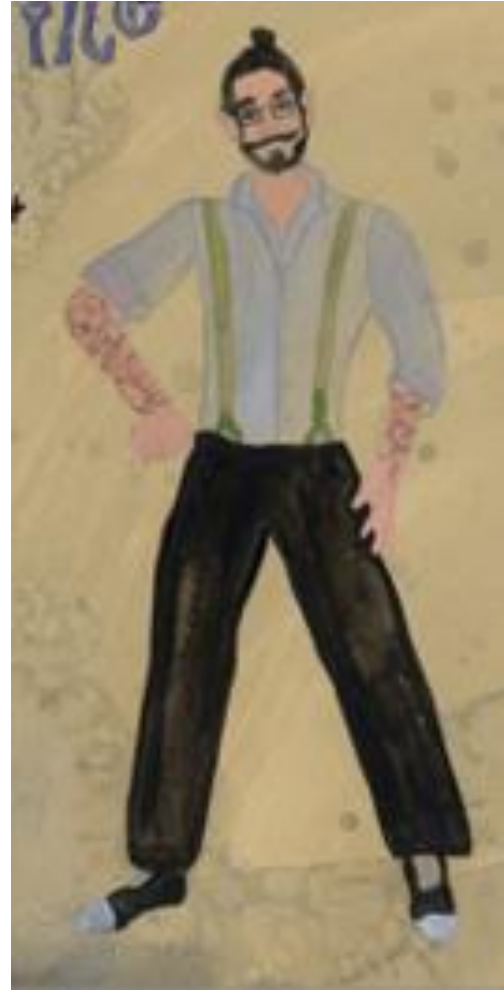

Figure 83: Design Martin Act II

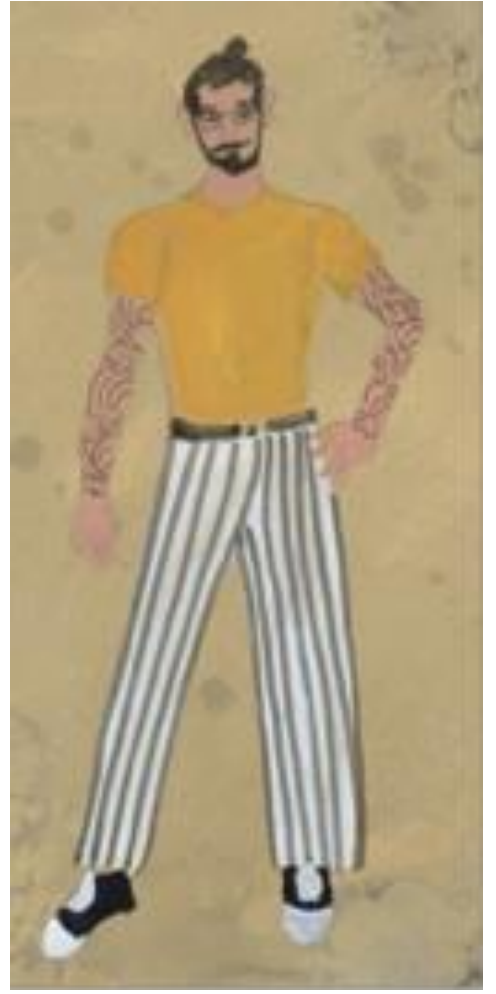

Figure 84: Design Martin Act II

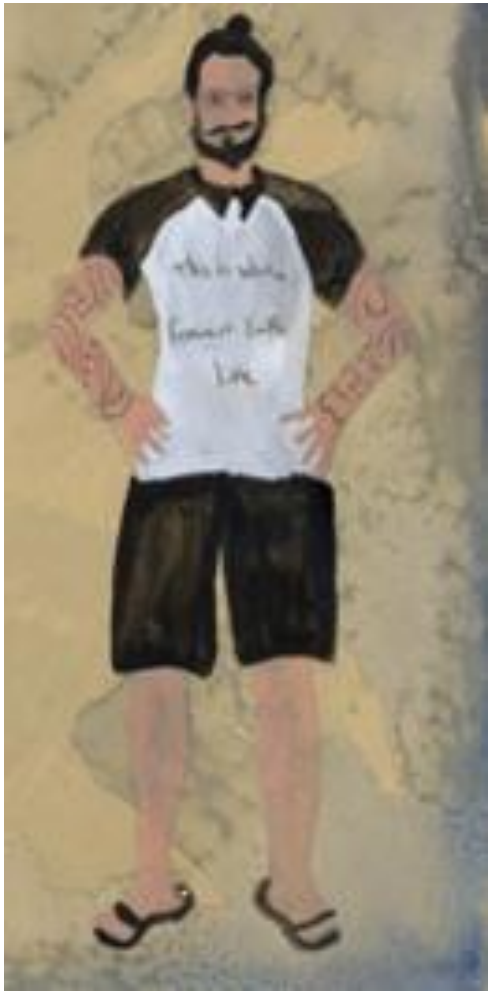

Figure 85: Design Martin Act II

Lin is a character who I had several ideas about how she could be portrayed. The first idea was to have a visually strong and political, lesbian woman (Figure 86). At this point in time during the research phase we were still setting the second act in the United States, which influenced the politics in slogans such as the notorious RBG, in relation to the Supreme-court 
justice Ruth Bader Ginsburg (Figure 87). Ginsburg fought for female rights in the United States and as an icon Lin would wear items inspired by her. The second look for Lin was influenced by the politics of the Black Lives Matter movement. T-shirts such as "white silence equals white consent" (Figure 88) and a garment with names of African Americans who have been brutalized by white police officers were options for Lin to wear (Figure 89). I felt this would only be appropriate for an African American actress to wear in the current cultural climate. While white allies are needed for a shift in American culture, the garments with the names of police brutality victims seems a step too far and could be insensitive. The pain associate with the victims is something that white people can be sensitive to but not truly understand as they not likely to be subjected to the same levels of police misconduct. Having an African American actress would also affect the characters of Ellen and Mrs. Saunders, as they are played by the same actress as Lin. The third and final idea for Lin was inspired by a modern gothic aesthetic. Dark colors that have some celestial and Wiccan influences (Figures 90 and Figure 91). Wiccan culture has a strong tie with feminism as it is a religion and social culture that emphasizes goddesses and being in tune with female energy. As a modern woman, this seemed like something Lin might be drawn to.

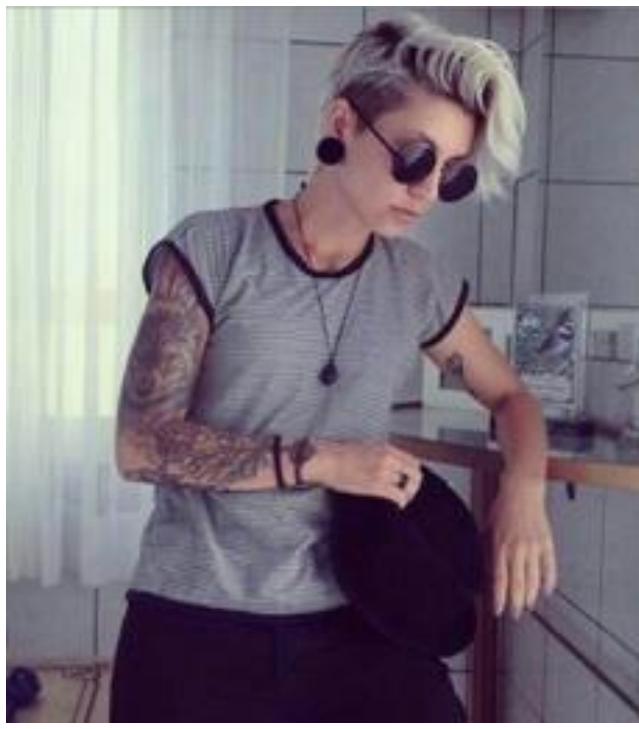

Figure 86: Research image for Lin Act II

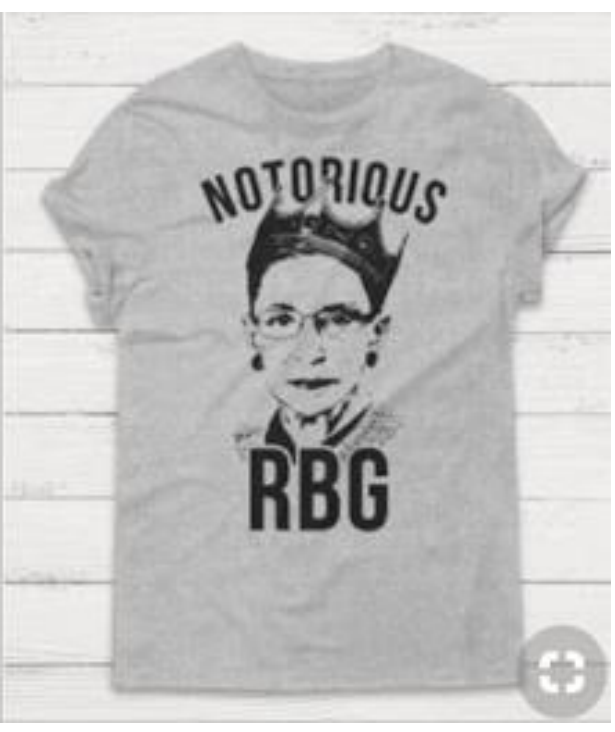

Figure 87: Research image for Lin Act II 


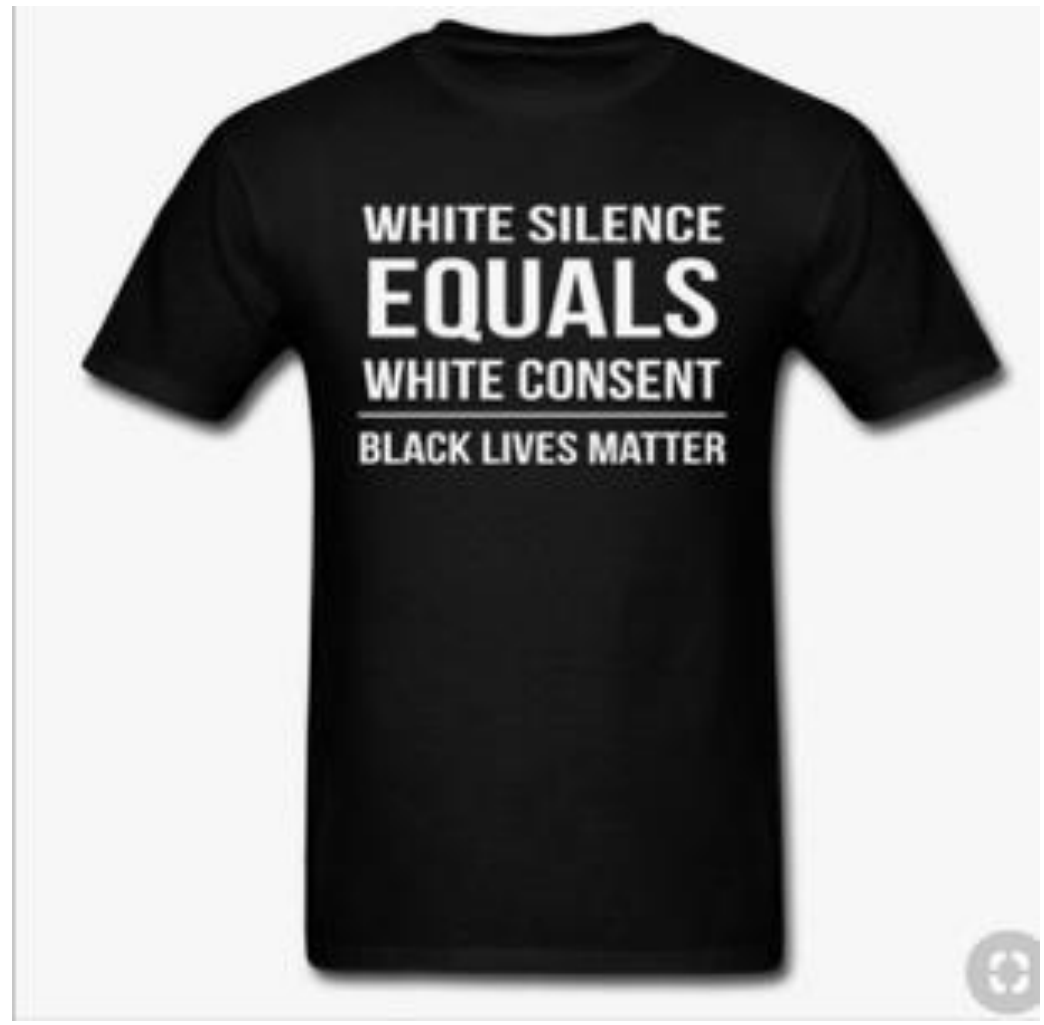

Figure 88: Research image for Lin Act II

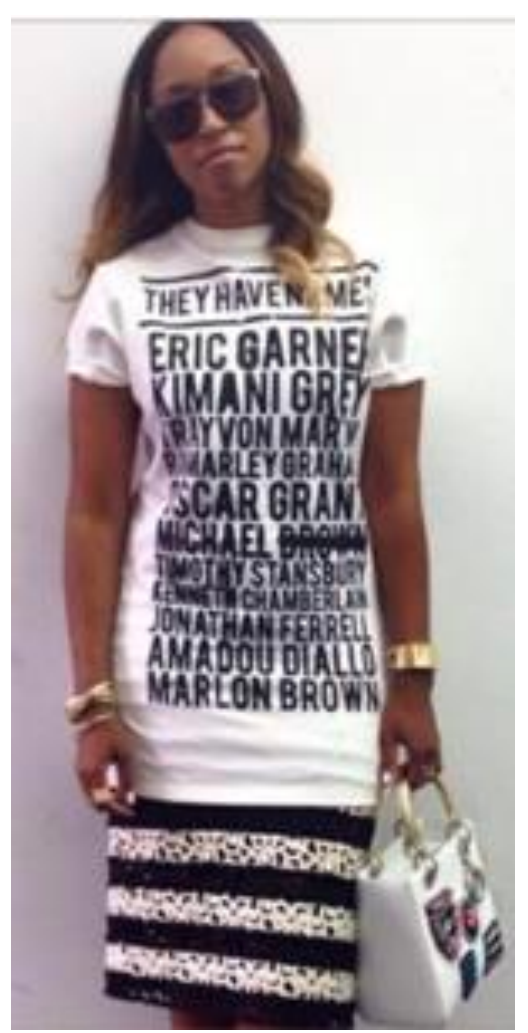

Figure 89: Research image for Lin Act II

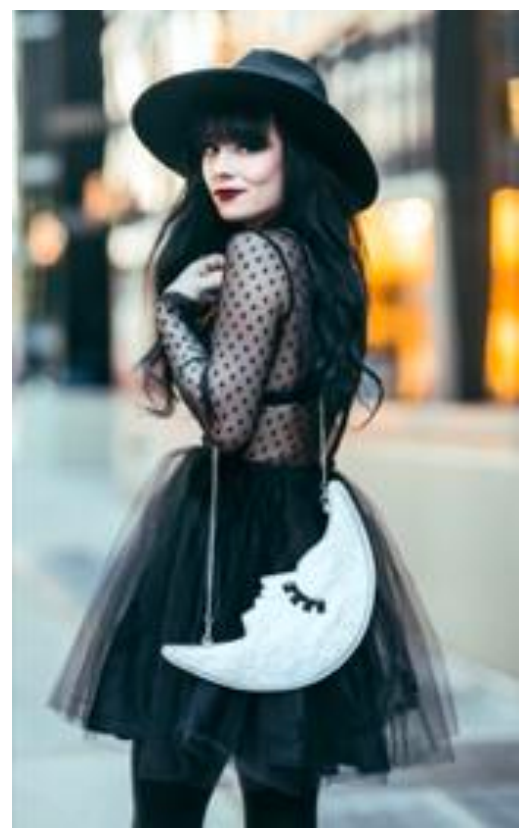

Figure 90: Research image for Lin Act II

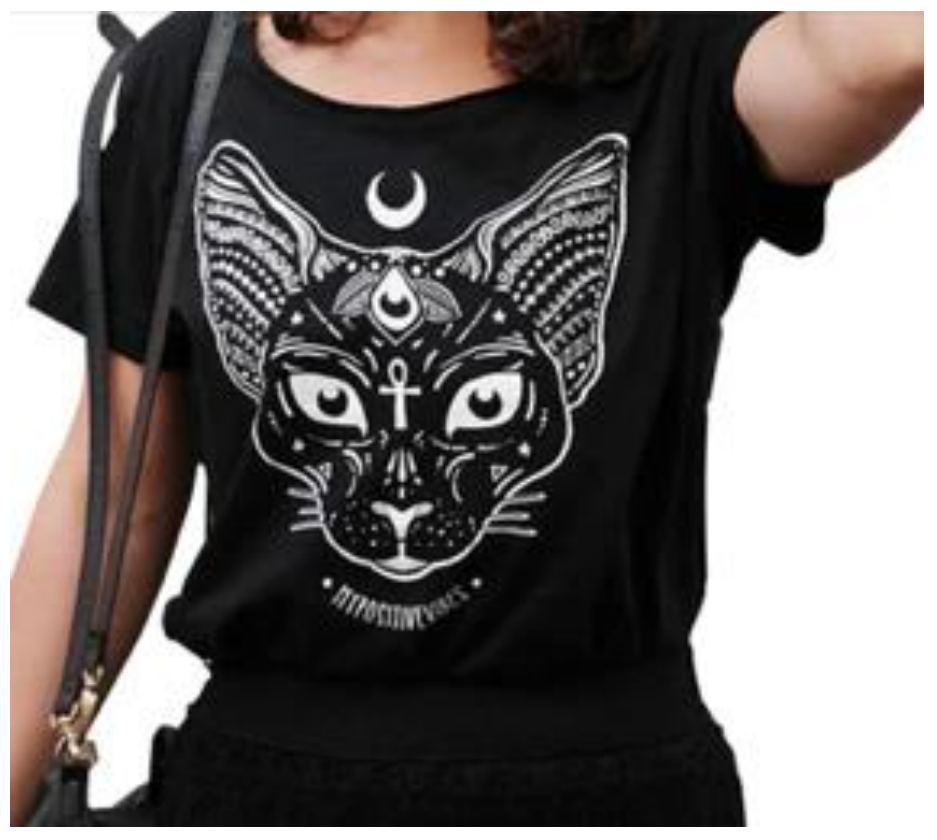

Figure 91: Research image for Lin Act II 
After casting was announced and I realized that Lin was being played by a caucasian actress, her character design solidified into a combination of slightly political modern wear with casually gothic influences. For the first scene in Act II, I had Lin wearing a black leather jacket and a "As above, so below" t-shirt, which is an occult phrase and combat boots (Figure 92). Her second look was a casual black t-shirt with a fish riding a bicycle, based on a feminist saying "A woman needs a man like a fish needs a bicycle" (Figure 93). For the "orgy scene" in the park, she wore a pair of black overall shorts with a plain t-shirt (Figure 94). In the final scene, she wore a pair of shorts with a full moon t-shirt, and a cropped, sleeveless, canvas jacket (Figure 95).

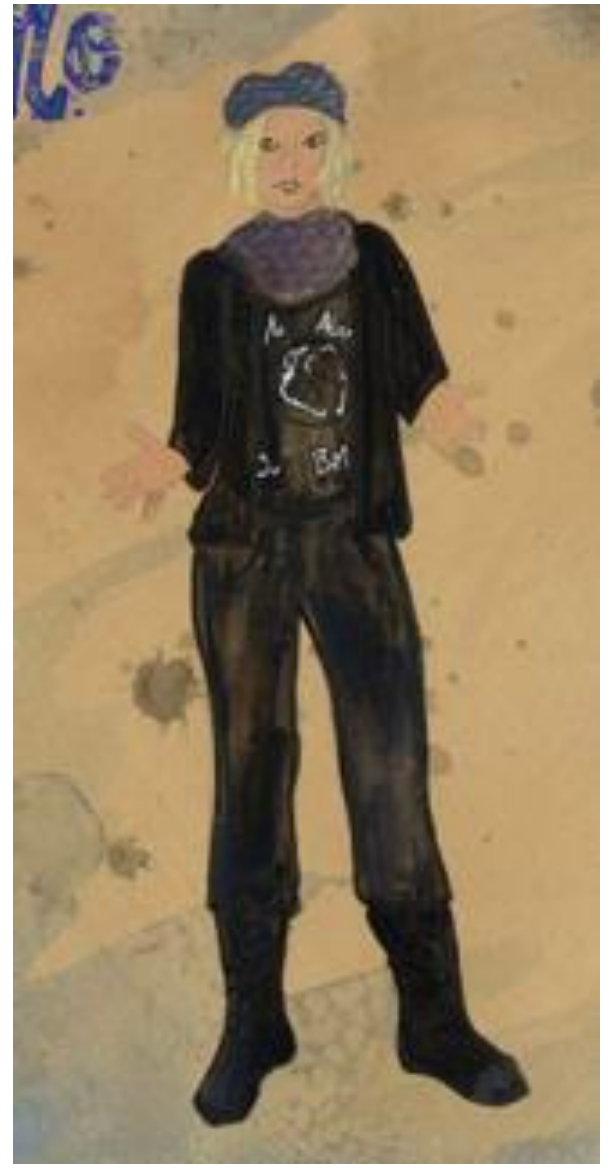

Figure 92: Final design Lin Act II

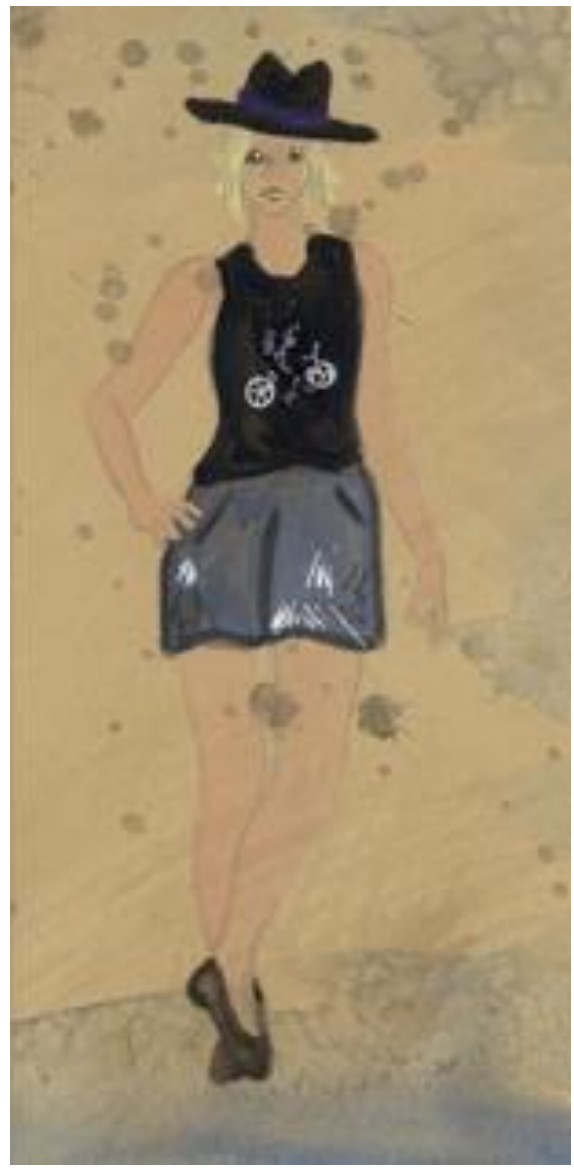

Figure 93: Final design Lin Act II 


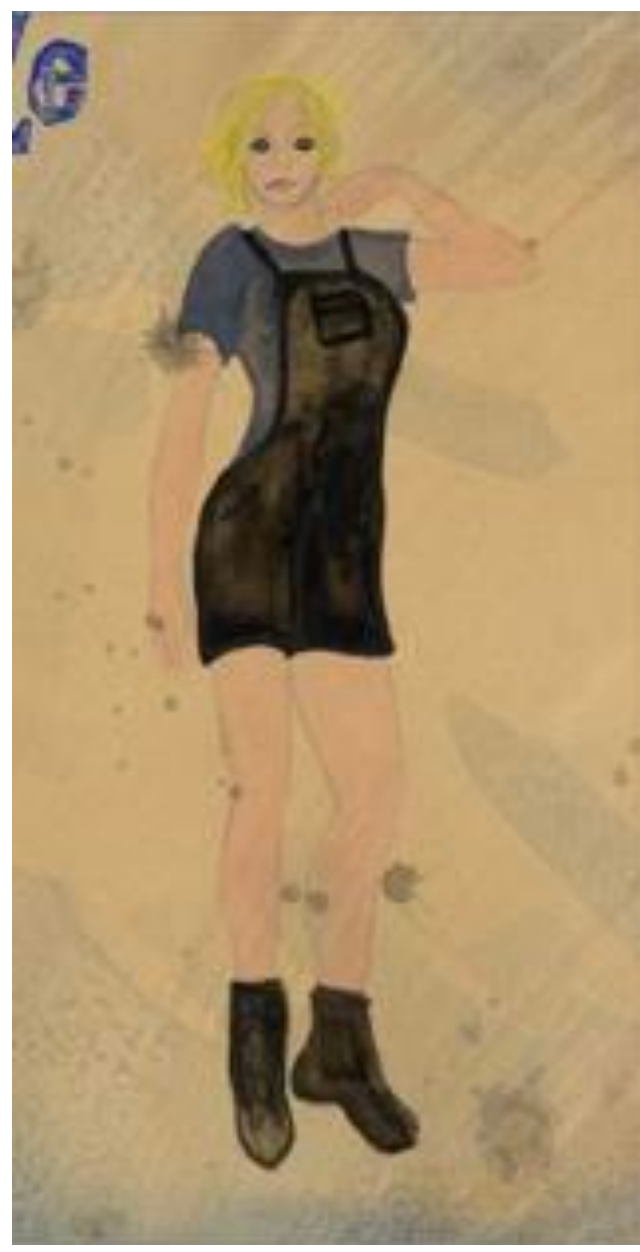

Figure 94: Final design Lin Act II

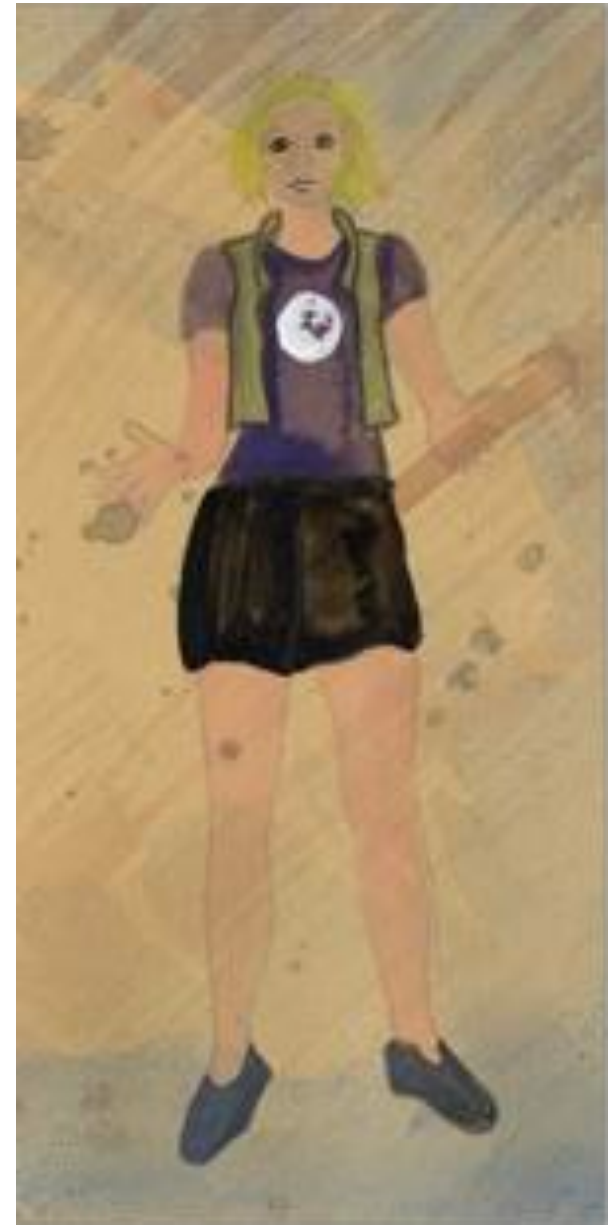

Figure 95: Final design Lin Act II

Lin's young daughter Cathy was inspired by images of young children who have some control over their own clothing choices (Figure 96 and Figure 97). Lin felt like a mother who would let her child try to dress themselves. Cathy was also played by the same actor as the character Clive. This decision by Churchill had Cathy being a foil for Clive. In Act I, Clive is strict with his children to stay in line with gender roles. Cathy breaks down those barriers and breaks down those roles by being loud and boisterous and dressing in bright colors while also playing with boys and guns. As the first scene of Act II is in winter, Cathy wears pants and a light winter jacket with a vibrant unicorn hat (Figure 98). She then wore a mismatched outfit of 
striped tights, a pink and purple tutu, and solid purple sleeveless shirt (Figure 99). In the final scene she wore a bright blue dress and a flower crown (Figure 100).

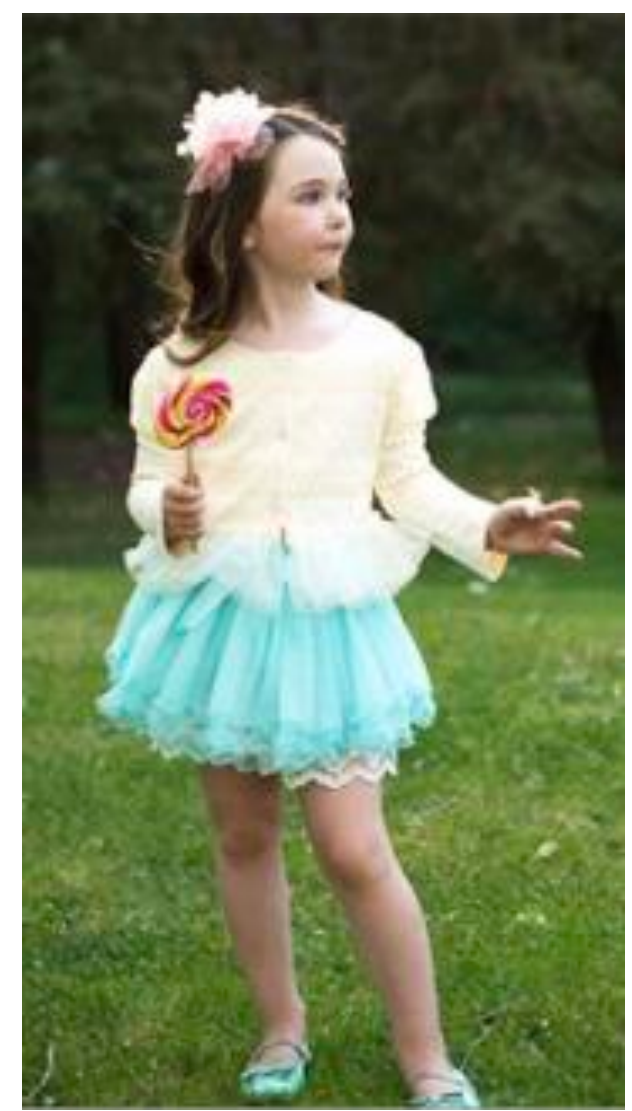

Figure 96: Research for Cathy Act II

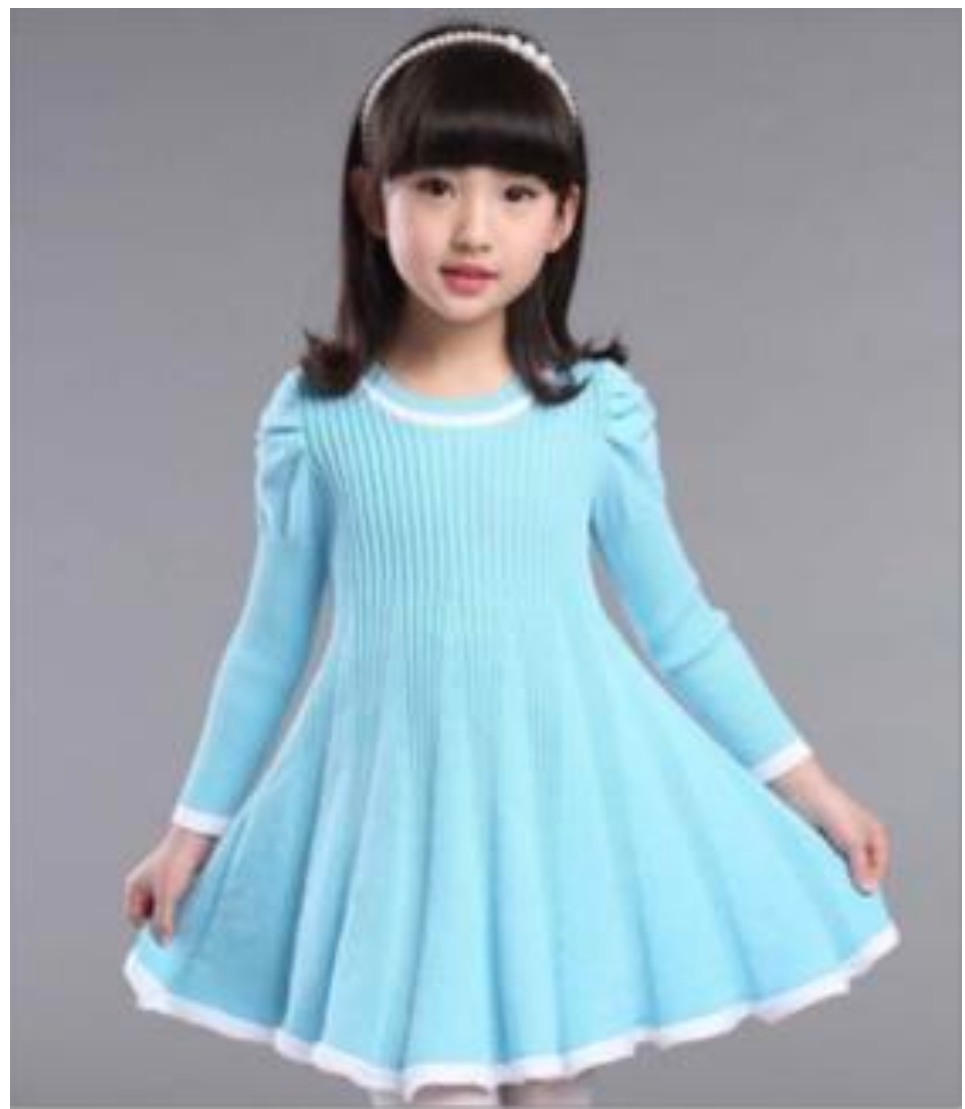

Figure 97: Research for Cathy Act II 


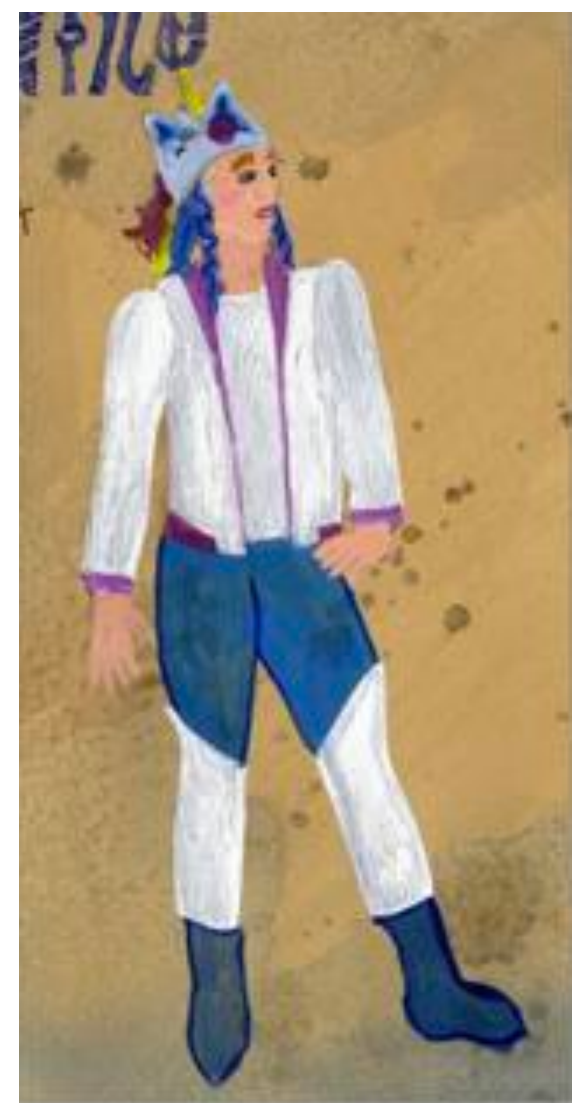

Figure 98: Design for Cathy Act II

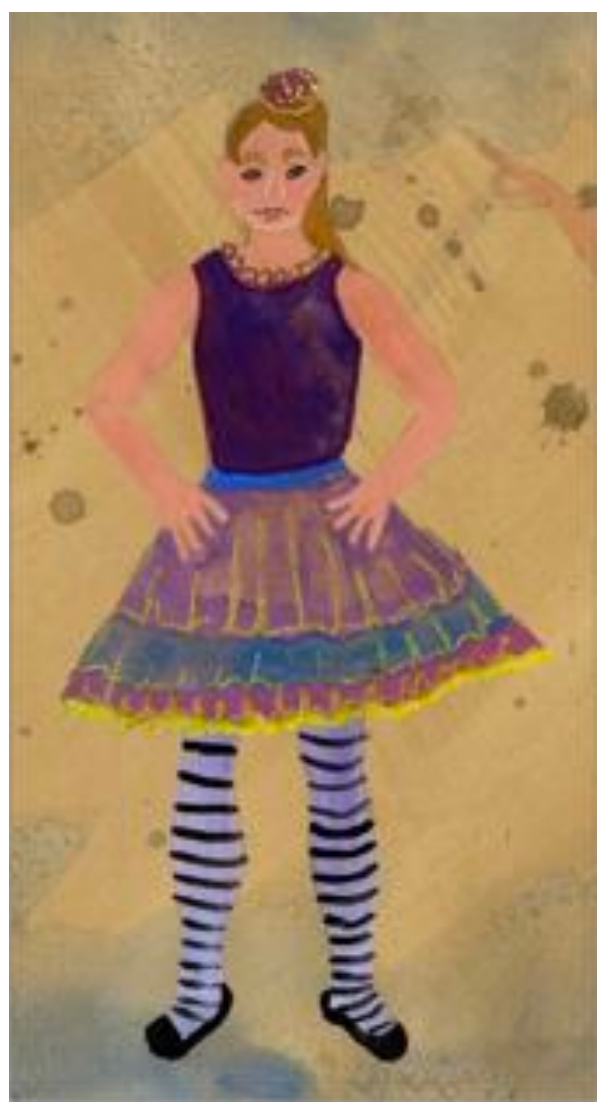

Figure 99: Design for Cathy Act II

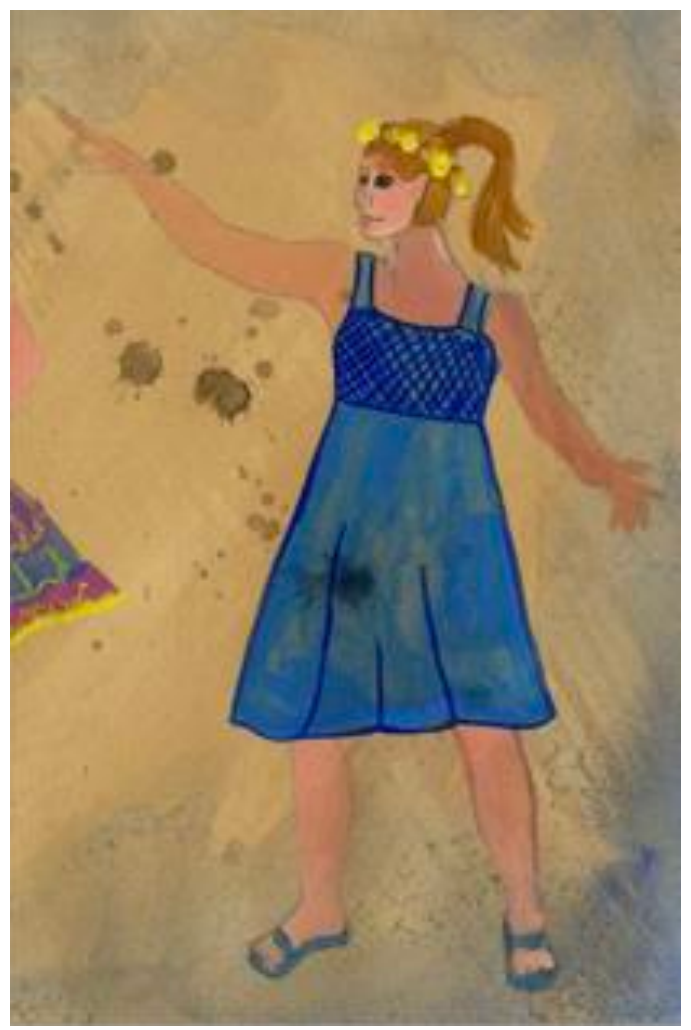

Figure 100: Design for Cathy Act II 
The same actor who plays Cathy also plays Lin's dead brother during the Act II “orgy scene" in the park. For a modern soldier, I researched generic camouflage clothing that would imply military service without designating a branch of the military (Figure 101 and Figure 102). A wig piece was created for the soldier so as he turned around there was the gory imagery of a blown-out gunshot wound on the back of his head.

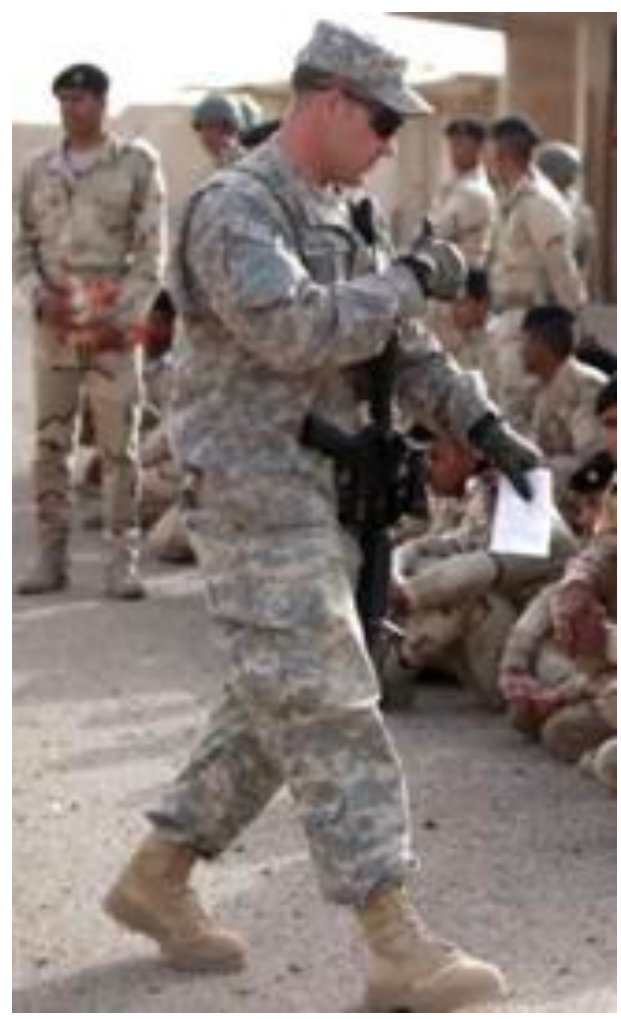

Figure 101: Research for Lin's brother Act II

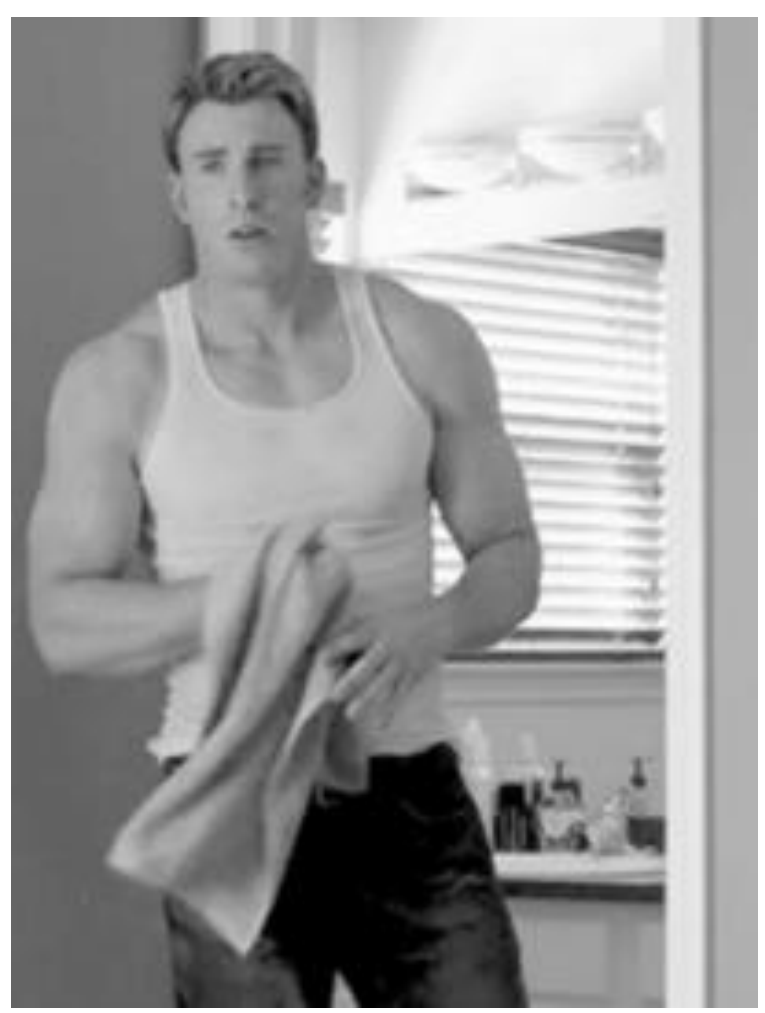

Figure 102: Research for Lin's brother Act II

Gerry is a very cosmopolitan man who cares about his appearance. His looks are "business style casual wear" that have a little bit of flare in their pattern and color (Figure 103). Gerry is interested in attracting and participating in sexual encounters while at the bar, in the train, or at the park. While identifying as a gay man, he has very little respect for Edward who leans towards feminine gender roles. This lead me away from portraying Gerry as an effeminate gay man, but more of a "metro-sexual" man. A second more extreme version of Gerry was inspired by "high runway fashion" (Figure 104). Gerry starts Act II in the park wearing a full 
patterned suit with a slim cut (Figure 105). As the season changes Gerry becomes a little more casual, but still stays very chic (Figure 106). In the final scene, he wore patterned shorts and a solid polo shirt (Figure 107).

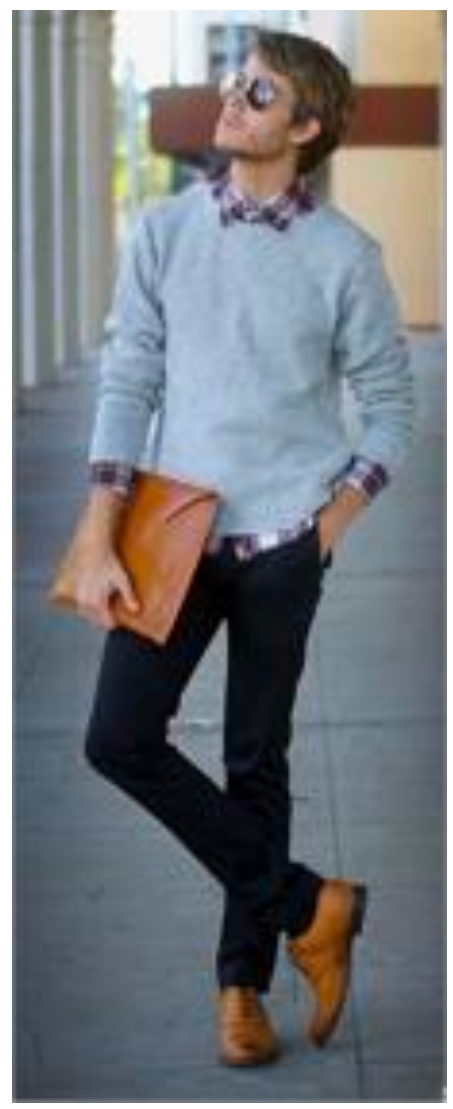

Figure 103: Research for Gerry Act II

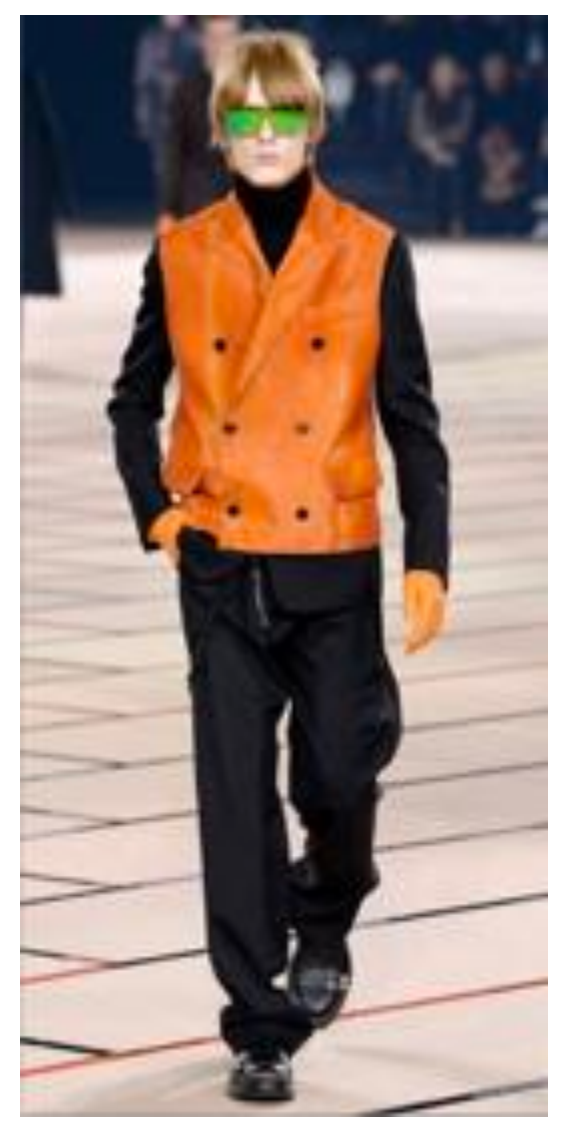

Figure 104: Research for Gerry Act II 


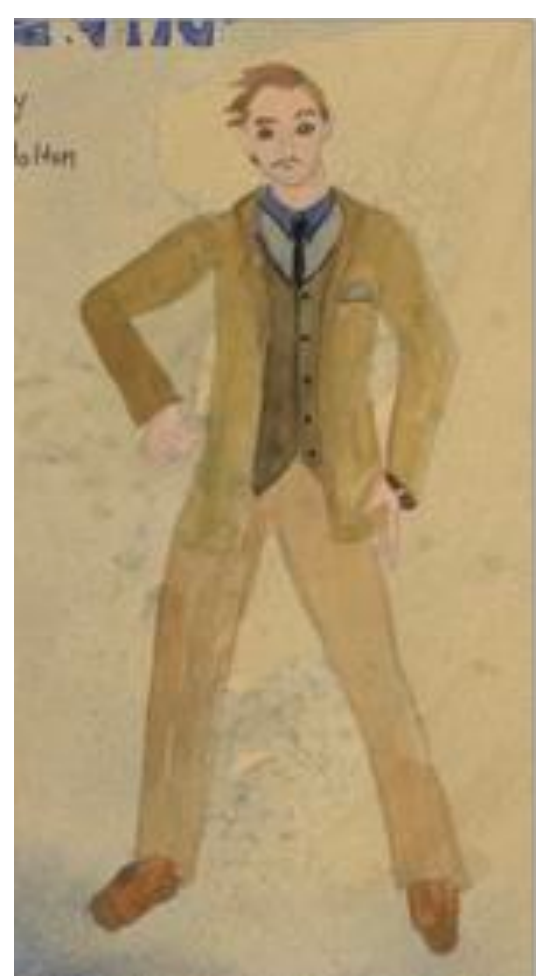

Figure 105: Design for Gerry Act II

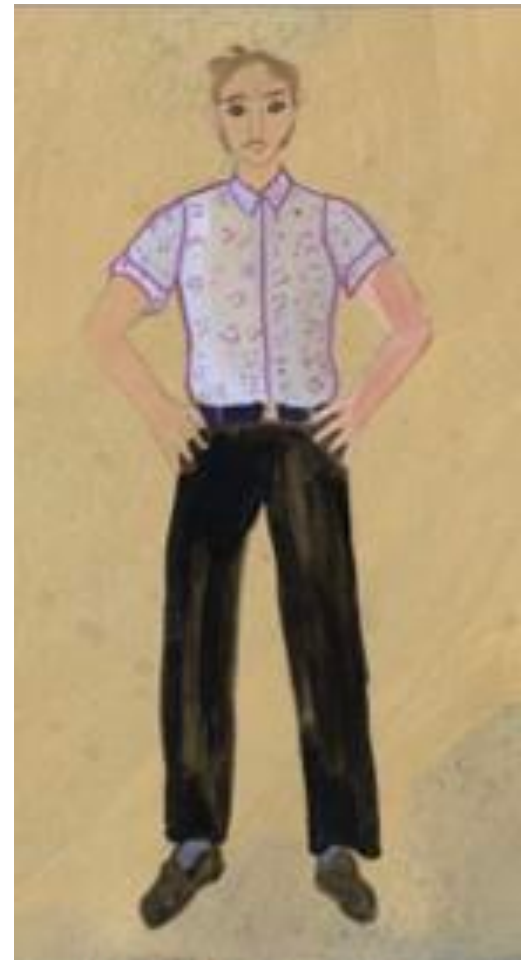

Figure 106: Design for Gerry Act II

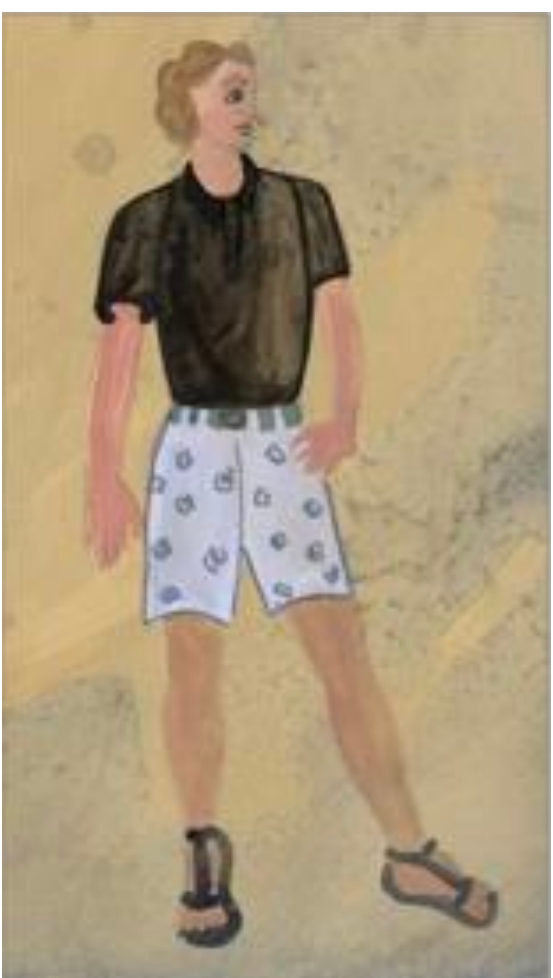

Figure 107: Design for Gerry Act II

As final renderings were due, all designs were approved by the director and the costumes moved from theoretical designs into the costume shop to be purchased or built. 


\section{PROJECT PROCESS}

With designs finalized, the costumes for Cloud 9 entered the costume shop. We had a preliminary meeting to discuss which pieces would be built. It was decided that as a shop we would build two dresses for the character of Betty in Act I, the blouse ruffle overlay and veil for Ellen's wedding in Act I, a skirt for Victoria in Act II, and a tutu for Cathy in Act II. It was also important at this time to create an undergarment structure for the male actor playing the character of Betty in Act I. Before the build could begin on his two dresses, they needed accurate undergarments from which to drape. A body suit with sculpted hips and breasts, was added to the build for the show (Figure 108 and Figure 109). There was a question at this time whether the body suit should be built into the dresses in order to help the quick change in Act II. The actor playing Edward changes back into the character of Betty in Act I for the final scene of the play. After a discussion with the Director and Stage Manager, it was decided that the actor had time to make the change. This kept the undergarment structure a separate piece.

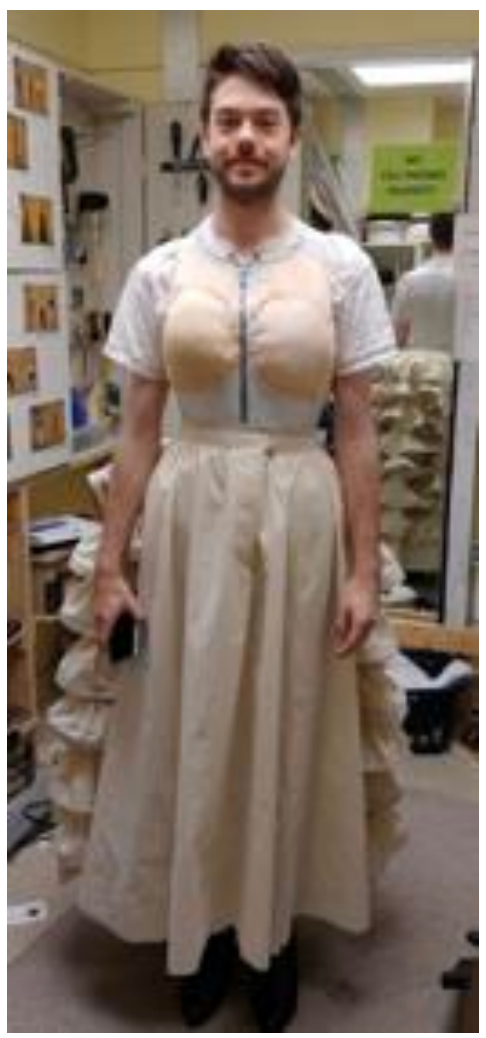

Figure 108: undergarment structure and petticoat.

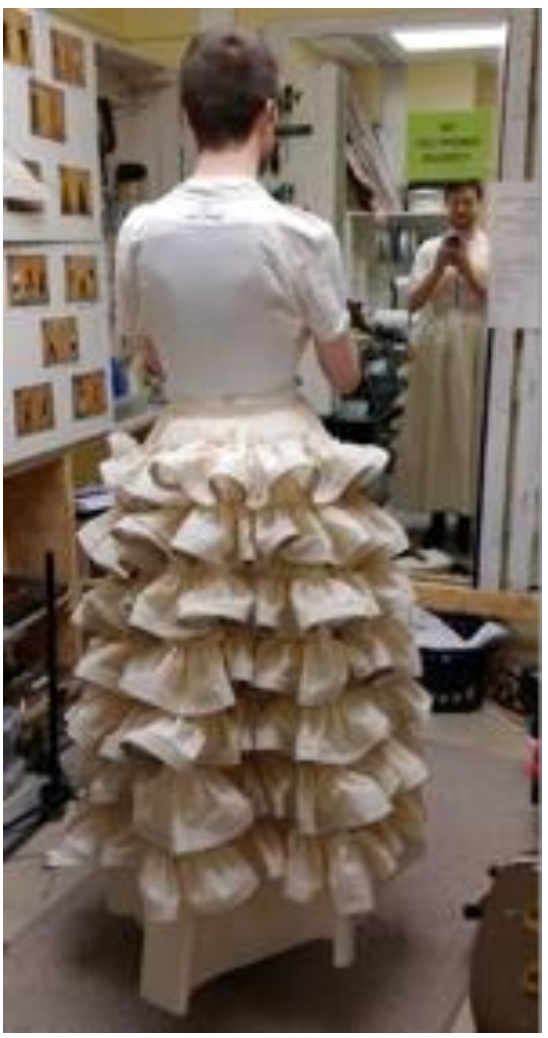

Figure 109: undergarment structure and petticoat. 
Once construction on the body suit for Betty was completed, the draping for Betty's dresses could begin. Two dresses were constructed for the character Betty, both to be used in Act I of the play. Figure 110 is an example of a primary fitting for one of Betty's dresses.

Understructure pieces were also important for the other character's in Act I. For the character of Maud, we had to layer several petticoats on top of one another in order to achieve the desired shape (Figure 111). The fittings for Act II were very straight forward because of mainly needing to adjusted ready wear items. These fittings mainly included adjusting hems and taking in garments as necessary (Figure 112 and Figure 113).

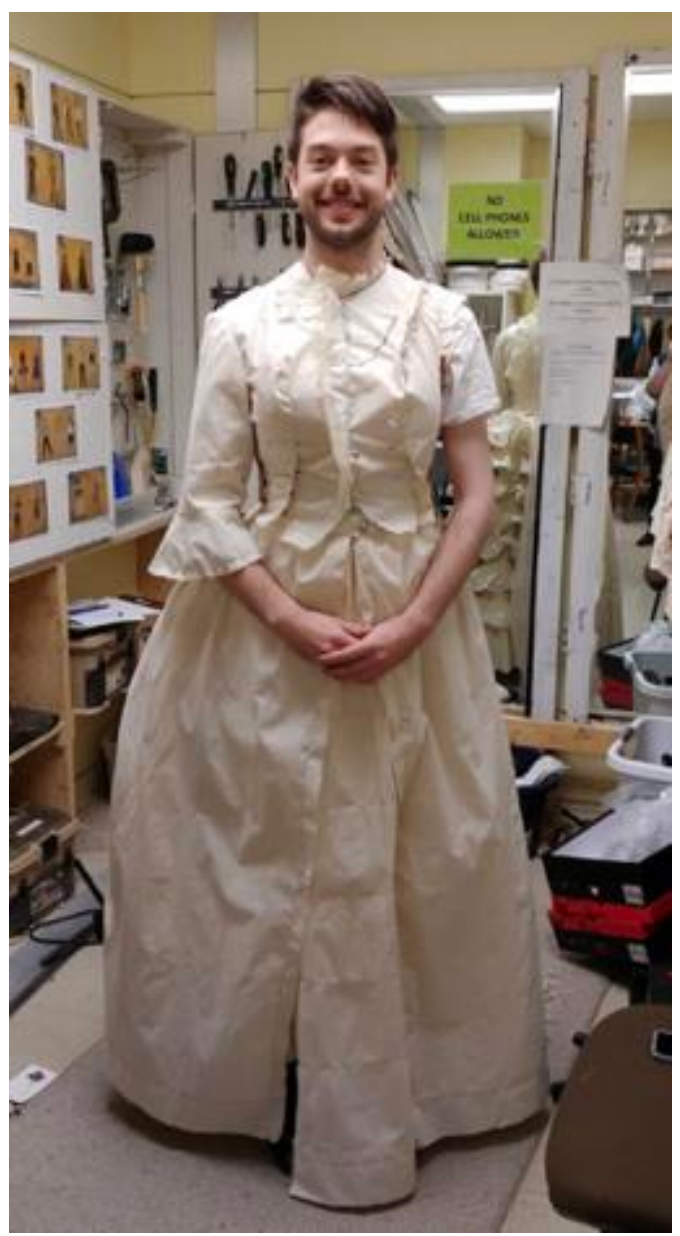

Figure 110: Fitting Photo of Betty

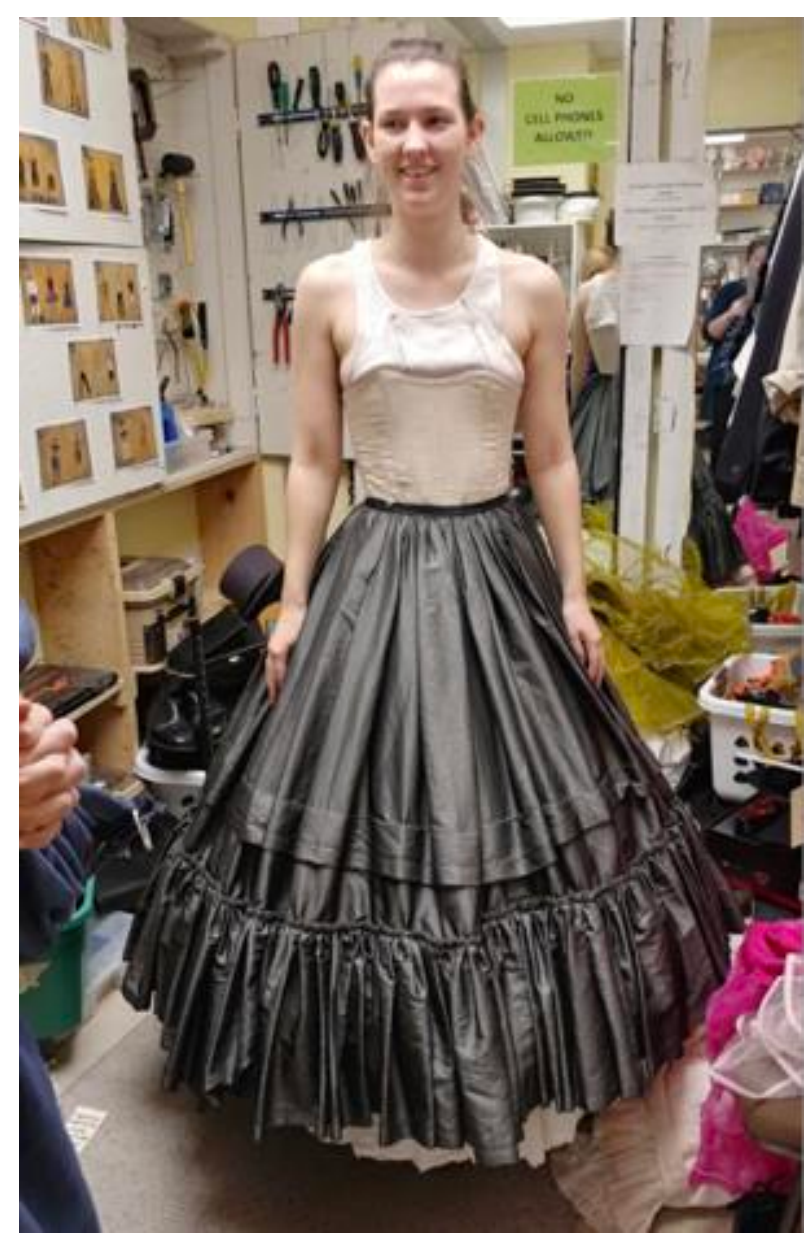

Figure 111: Fitting Photo of Maud 


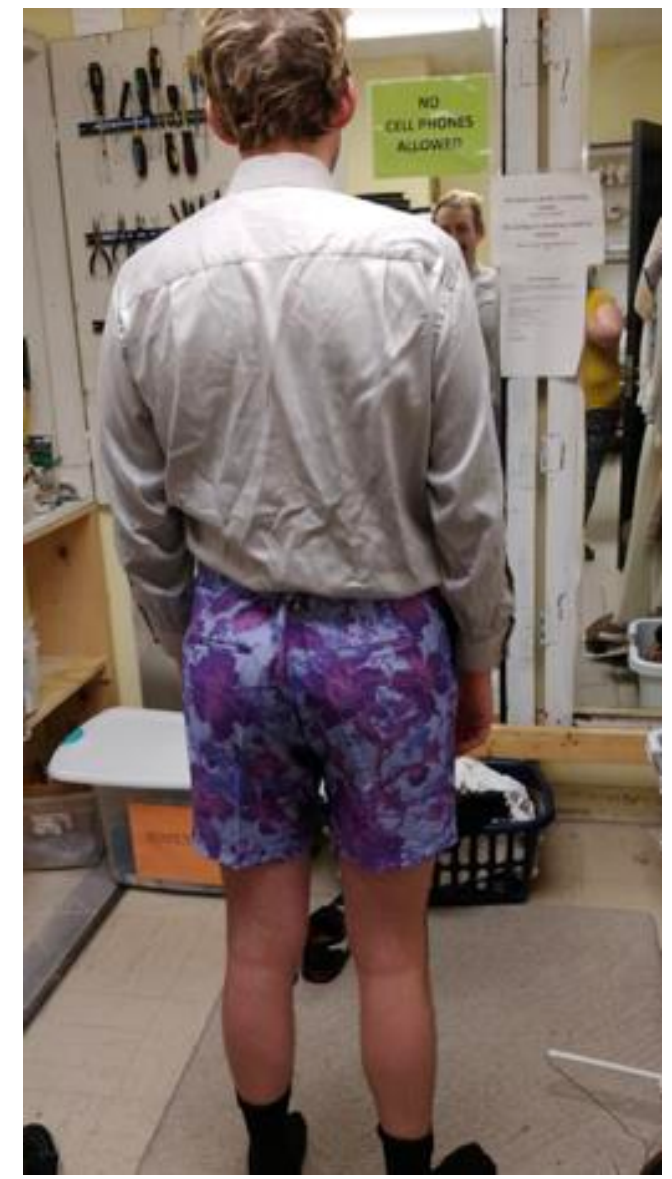

Figure 112: Fitting Photo of Gerry

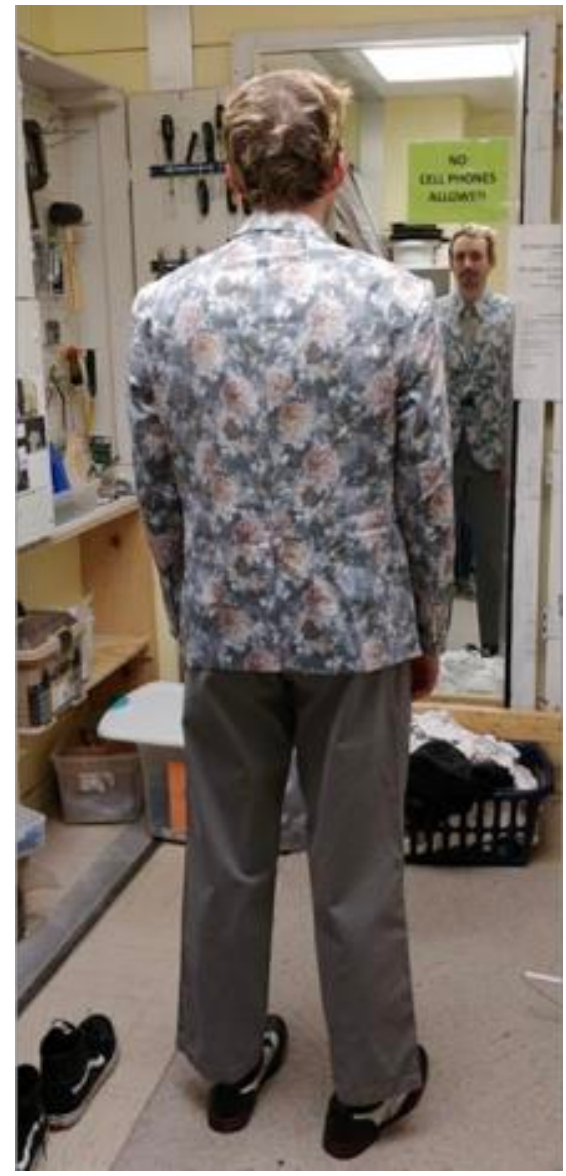

Figure 113: Fitting Photo of Gerry

I began the ordering process on September 21,2018. The majority of the modern-day items were either sourced from thrift shops or purchased online. For a selection of items that I had in mind for certain characters, I turned to websites like "Etsy" where you can actively talk to the person making them. This was great for items that we did not have time to make in the shop. One of the major purchases was for Betty's dresses in Act I. I shopped for a wide vertical stripe, but was unable to find one online with the right width and color. For this I turned to the website, "Spoonflower." On this website you are able to have a custom printed pattern made onto various weights of fabric. This was helpful with being able to control the pattern of the fabric, the downside was how long it took to receive the order. Because of the yardage, "Spoonflower" 
originally only sent a sample to be confirmed before they sent the whole order of fabric. This delay put Betty's main dress way behind in its build. This was problematic for Chloe Cappuccilli, who was in charge of this build. However even with the delay Cappuccilli was able to have the dress finished without embellishments for first dress. Delays like the fabric order are notorious for slowing down progress on show builds and this also adds to the stress that often can accompany the atmosphere in a costume shop.

One of the jobs of the costume designer is to keep track of the budget during the design process. I took out purchases that I knew were going to be large, such as the "Spoonflower" fabric purchase (Figure 114). As more purchases were made, I added them in the apple program "Numbers." I purchased many of the pieces for Act II when I was not able to find them in local resale stores. As purchases added up, I removed money from my estimated dry-cleaning expense to attempt to stay under budget (Figure 115). As costumes were completed in the shop, I created a "Scene Breakdown" detailing the items characters were wearing during individual scenes, see Appendix D "Scene Breakdown."

\section{Cloud Nine Budget}

\begin{tabular}{l|r|}
\hline COSTUME BUDGET & \\
\hline Total & $\$ 4,000$ \\
\hline TOTAL INCOME & $\$ 4,000$ \\
\hline MONEY OUT & $\$ 89$ \\
\hline Costume Shop Supplies & $\$ 450$ \\
\hline Estimated Dry Cleaning & $\$ 15$ \\
Costume Shop Supplies & $\$ 9$ \\
Swatches- Spoonflower & $\$ 280$ \\
Wig Lace- His and Her & $\$ 99$ \\
Wigs- Amazon & \\
\hline
\end{tabular}
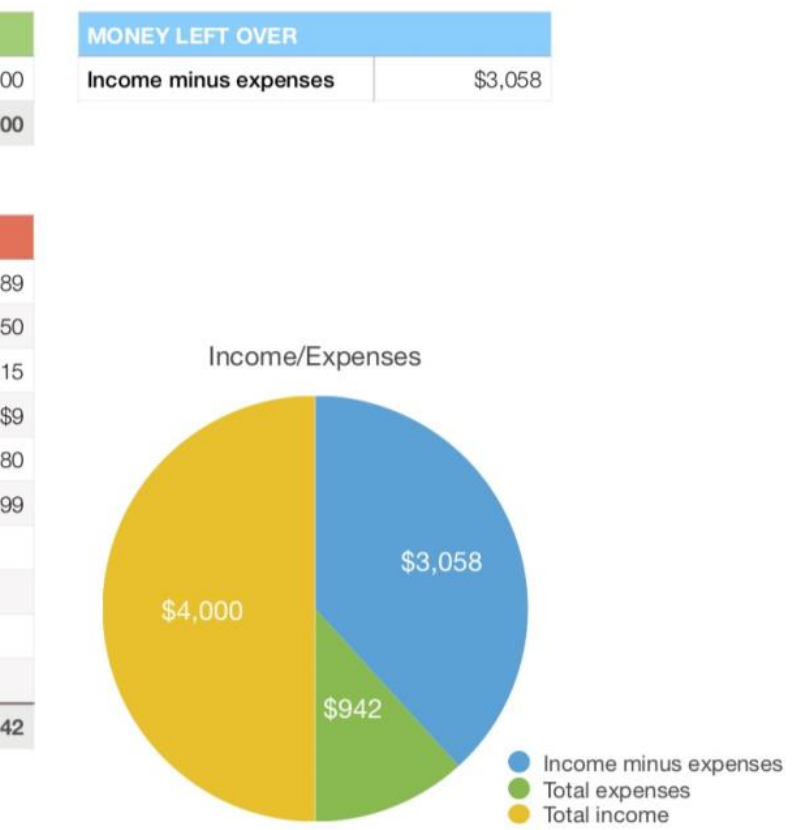

Figure 114: Primary Budget Sheet 


\section{Cloud Nine Budget}

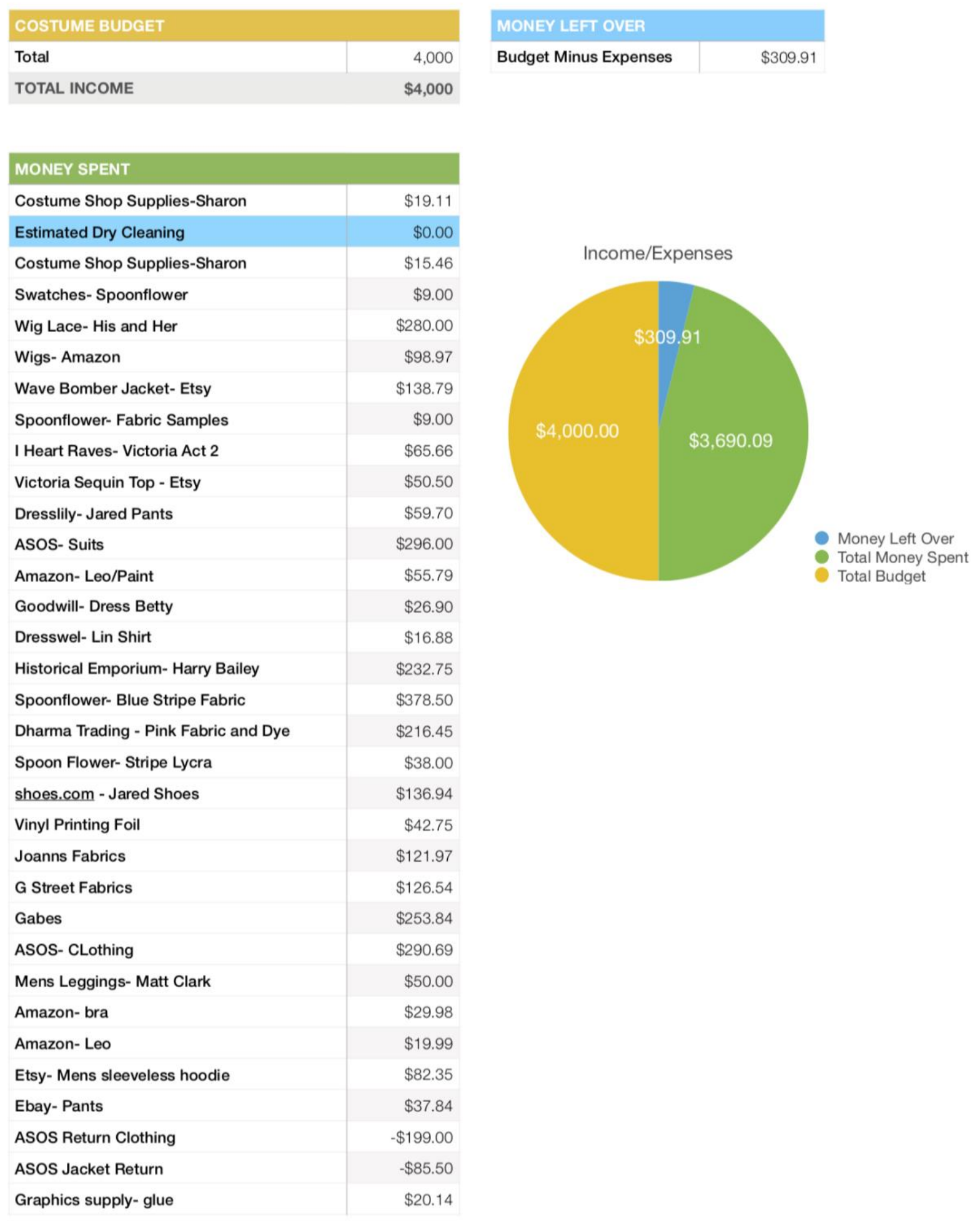

Figure 115: Budget Sheet 
One of the first problems for costumes was the use of rebar for the African nail fetish art in the set design. When originally discussed with the set designer, she emphasized that the nails would be made of rubber that would be flexible and not injure the costumes. During presentations to the undergraduate students, Mariano mentioned that the nails would in fact be made of rebar with rubber tips. This was different from our first discussion of the nails. In Act I, Betty, Mrs. Saunders, and Ellen were all designed to have full skirts with petticoats, while Maud would have even a larger skirt because of being slightly out of date. We had a meeting in the scene shop and this was discussed at length, but due to budget constraints on the set no changes were made. This was still an issue by the time we entered first dress and was ultimately solved through changing the blocking. This is further discussed in the "Evaluation of Costume in Performance" section.

The second major problem as a result of the scenic design, was with the boulder "bodies" that the characters were walking on. The bodies were sculpted out of foam and covered with a product called "Sculpt or Coat." The problem surrounded the subject of the actor's shoes. I attempted to order shoes for Jared Munson, who played Betty in Act I, as soon as casting was released. I knew we did not have a feminine style boot in his size in stock that would look like a period 1870's boot. In female shoe sizes, Munson was a size 13 which was difficult to find in local stores. As discovered in a late production meeting, the heel of the shoes for those climbing on the body structures could not be smaller than 1 inch because a smaller heel would punch into the foam of the bodies that made up the majority of the set. While troublesome for the female cast, most of their shoes could be easily acquired with the correct heel size through the WVU costume stock. Munson had to have new shoes ordered which took needed funds from the budget. I could not return Munson's first shoes because they had already been used in rehearsal several times. I ended up ordering shoes through the use of the website Amazon because of their 
fast shipping. Due to time constraints with ordering, Munson's shoe ended up looking very modern.

Traditionally, Victoria in Act I is played by a doll. In the beginning of the design process, Victoria was going to be provided by the props department and then dressed by the costume shop. However, after an early production meeting Professor Mary McClung provided a puppet that was the right size for the character of Victoria (Figure 116). While the puppet had to have a different wig and costume, it worked out well for both props and costumes. This also allowed the actors more time to play with the puppet in rehearsal and get used to its movements (Figure 117).

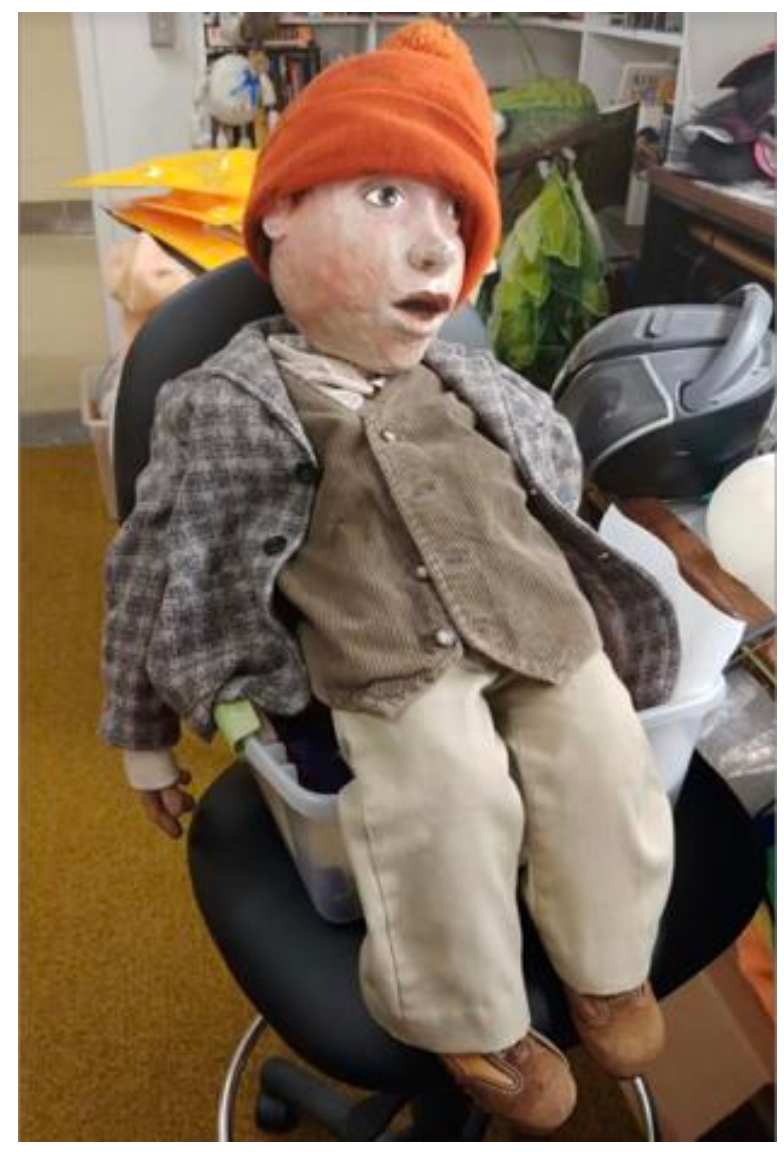

Figure 116: The Puppet that would become Victoria in Act I 


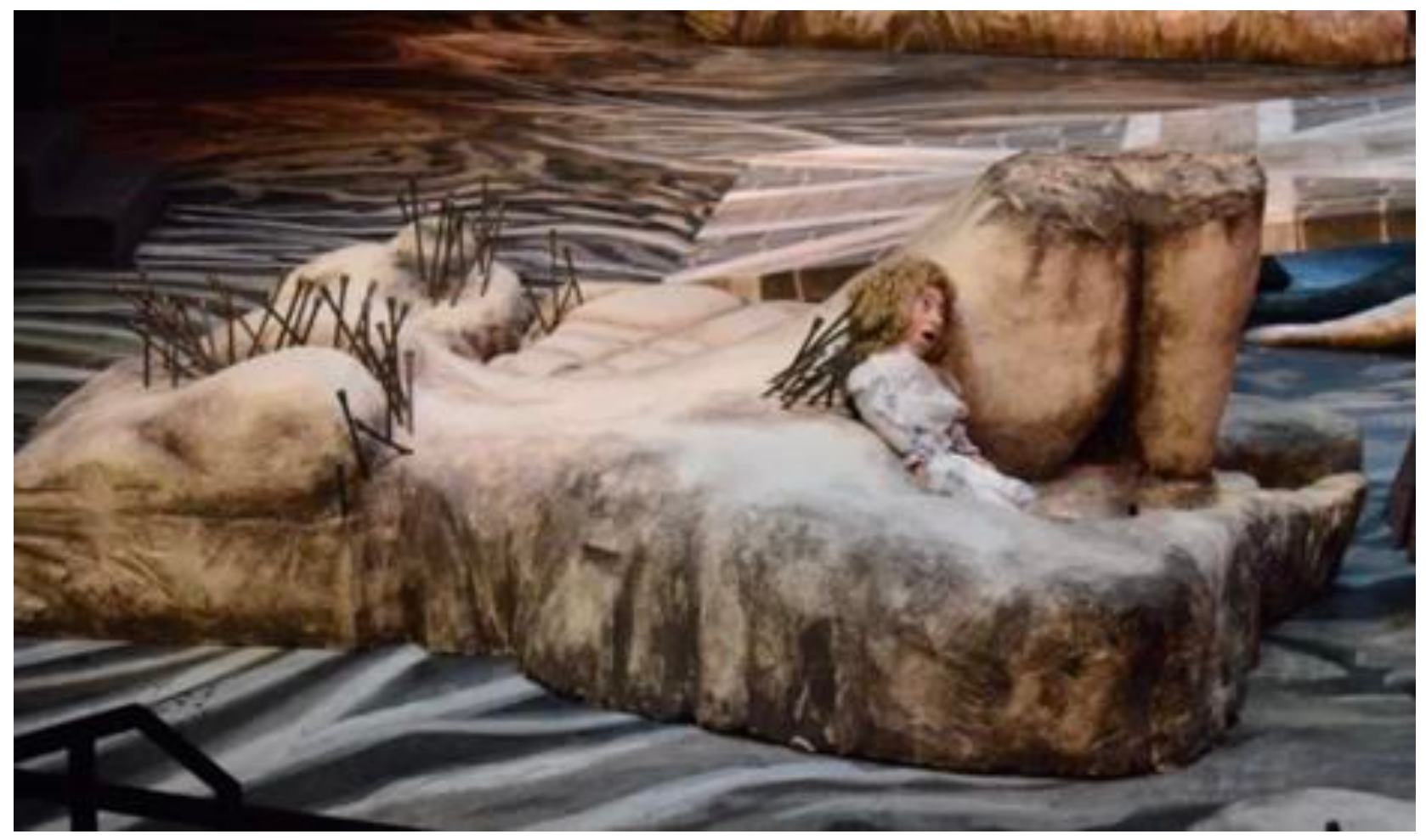

Figure 117: Victoria Puppet alone on stage

With some of the modern garments in Act II, we created the designs instead of purchasing pre-made garments. For Victoria's skirt build in Act II, we used a tool called a heat press. With the use of pressure and heat, this machine transfers colored foil onto fabric in select areas depending on where you place the glue. For her skirt in Act II, individual pieces were cut into shapes of celestial designs and placed onto the skirt before it was assembled. This was an exciting tool to learn to use and allowed for custom designs to be applied to fabric. In addition to the heat press, the shop stenciled and hand painted on t-shirts, such as Edward's "octopus" shirt (Figure 118 and Figure 119) and Lin's "fish-riding-a-bicycle-shirt". 


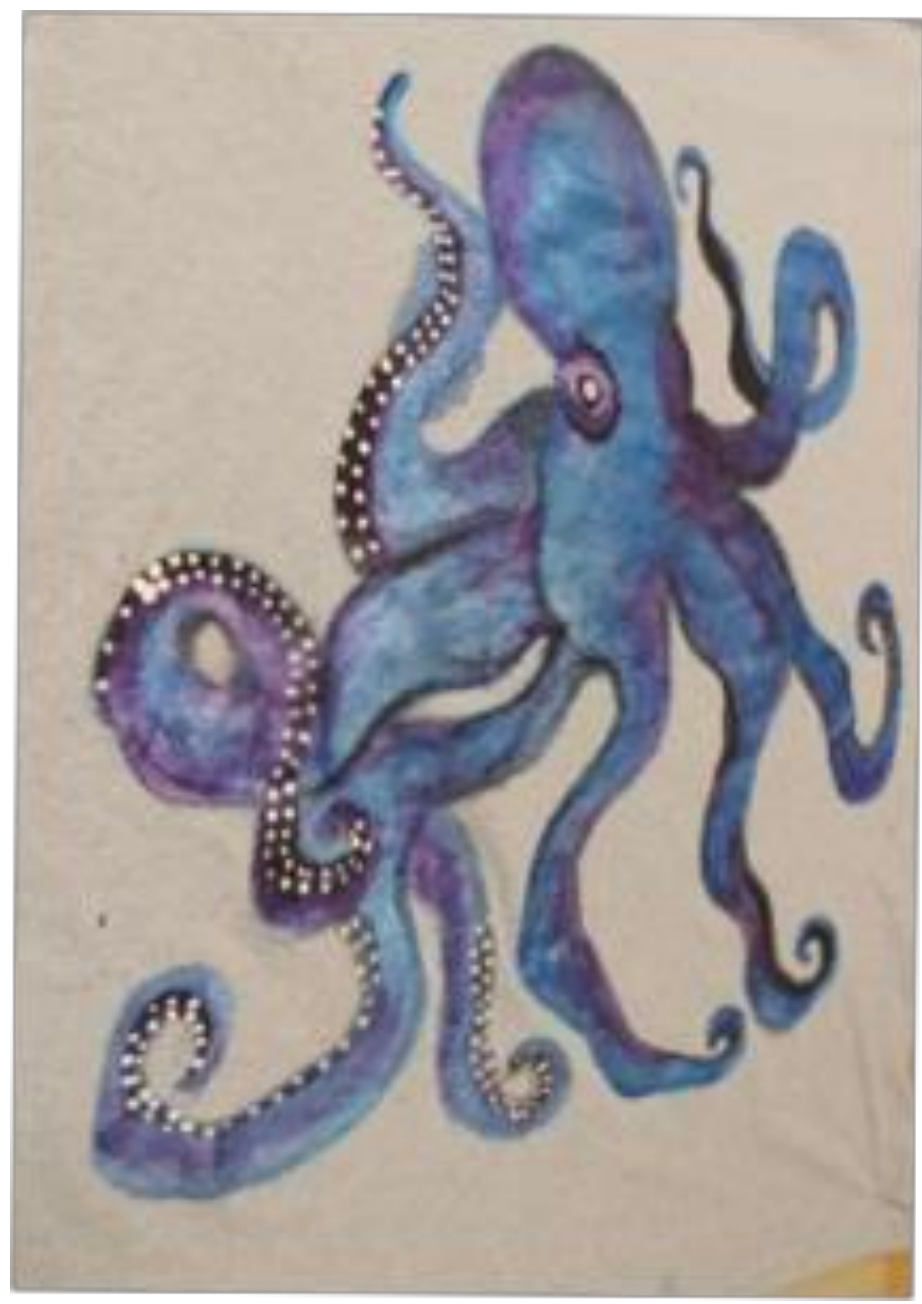

Figure 118: Octopus shirt painting

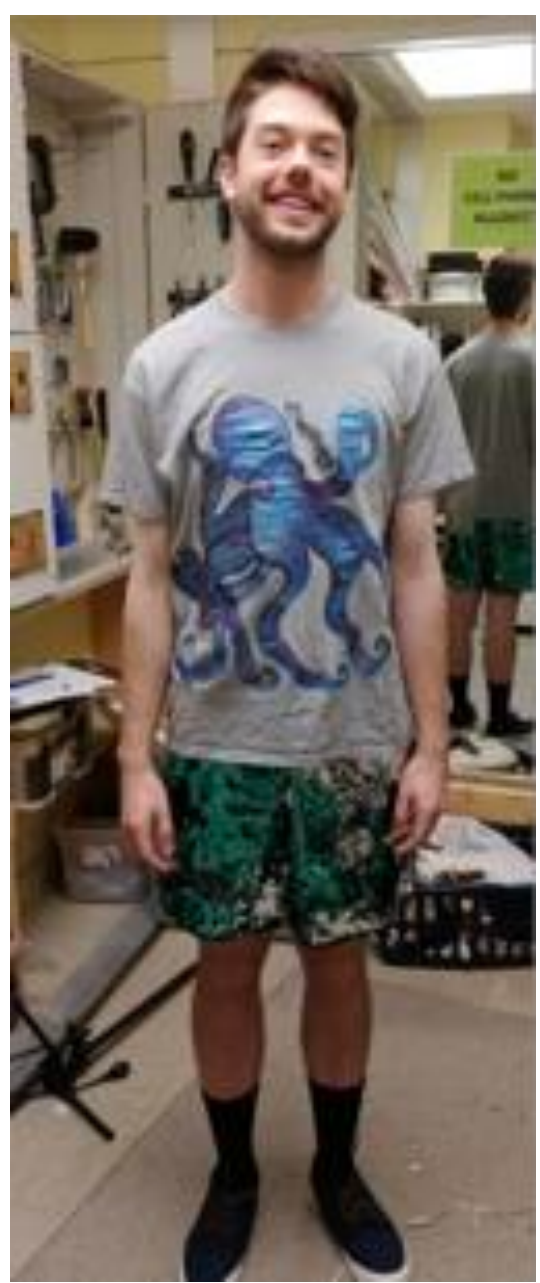

Figure 119: Octopus shirt painting

After designs were completed, I had a meeting with the Lighting Designer to discuss the amount of color being used in Act II. This was concerning for him and limited his color palette for the act. As purchased items entered the shop for Act II he was able to borrow the items and look at them under different lighting "gels." We decided to spray some of the more sequined items with a clear matte coat in order to tone down the reflections. I also tea-dyed down white costumes, like Cathy's jacket in Act II so they would not be a very bright white on stage. 


\section{EXECUTION OF COSTUMES IN PERFORMANCE}

This section discusses the process of the costumes being introduced to the dressers in charge of running the show and what happened in the technical rehearsals of Cloud 9. We had eight Dressers and a Wardrobe Supervisor who were under the guidance of the Graduate Wardrobe Supervisor, Chloe Cappuccilli.

The first day with the costume crew we had wig and makeup training with the actors. We had ten wigs in the show and one false hair piece. The goal of the day was to introduce the actors who had wigs to their dressers and teach the dressers who may not have worked with wigs before how to put them on and store them each night. Each actor had a personal dresser, with the exception of a floater tasked with quick changes. During wig training, we went over how the actor needed to prepare their hair. This requires actors with long hair to pin-curl before the dressers helped them put on their wigs. For actors with short hair we use a method of creating a base for the wig to grab onto by wrapping an ace bandage around their heads before applying the wig cap.

On wig training day, we ran into a problem with the wig for Martin in Act II. While we had wig fittings with the actor Ryan Ernst, the wig for this character did not fit. It was not determined how the mix up with the wig happened, but he had tried on various wigs during a fitting and it was assumed that the wrong one was kept to be worked on for him. A new wig was pulled for him and quickly styled, but was not ready for the first dress rehearsal.

When the dressers arrived for the first run of rehearsal we went through their responsibilities during the show. This included talking through each costume and wig change. The beginning of first dress rehearsal for the costume crew started with working on the shift between the Act I and Act II of the show. Act I ended with a blackout before intermission. The set crew and costume crew were needed for the transitioning of the set between the acts. Many of the sculptural body-pieces, which made up the set design, needed to be moved in order to lay 
down the grass for the park, and then select body pieces were kept on stage. When Act II started, the actors were wearing some of the clothing items that they had at the end of Act I. They then moved in a choreographed fashion to the song "Under Pressure" by David Bowie and Queen.

During this time, they put on pieces of the character that they transition into during Act II. The complete list of costume pieces for the intermission is located in Appendix E. The transition was important for costumes because not only did it show the passage of time between the acts, but also shows the characters transitioning into who they played in Act II. While the Scenic Design elements needed time to transition between the acts, it was the Lighting Design that made this visually interesting for the audience (Figure 120- Figure 122). The lights worked in time with the music and the actor's movements to make this transition dynamic. When the transition between the acts ended, there were only a few moments before the first scene of Act II started. Practicing this transition sequence was important because it involved the scenic and wardrobe crews working in tandem. Due to the time spent on the transition, we were unable to make it through a full run of the show on first dress and only made it to the very beginning of Act II.

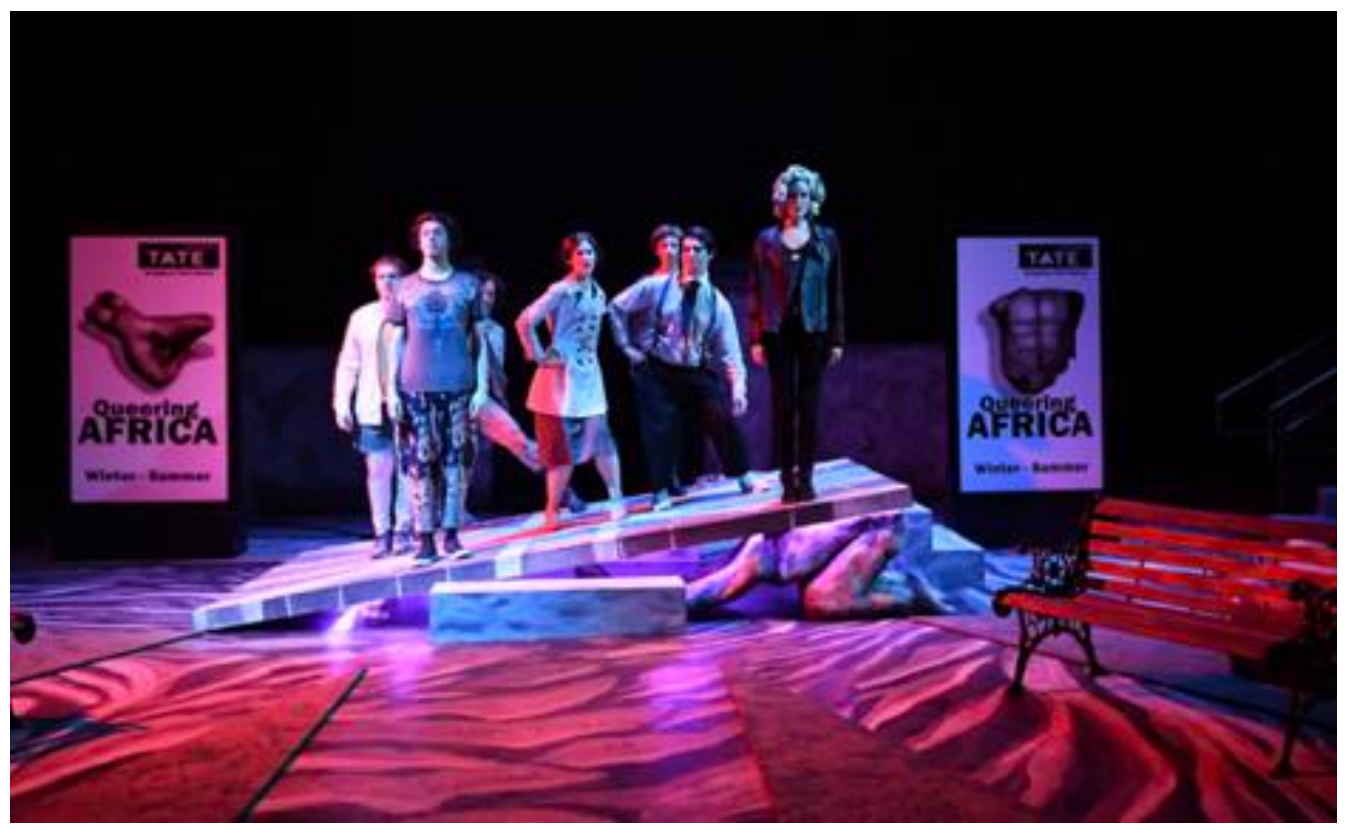

Figure 120: Act I to Act II transition 


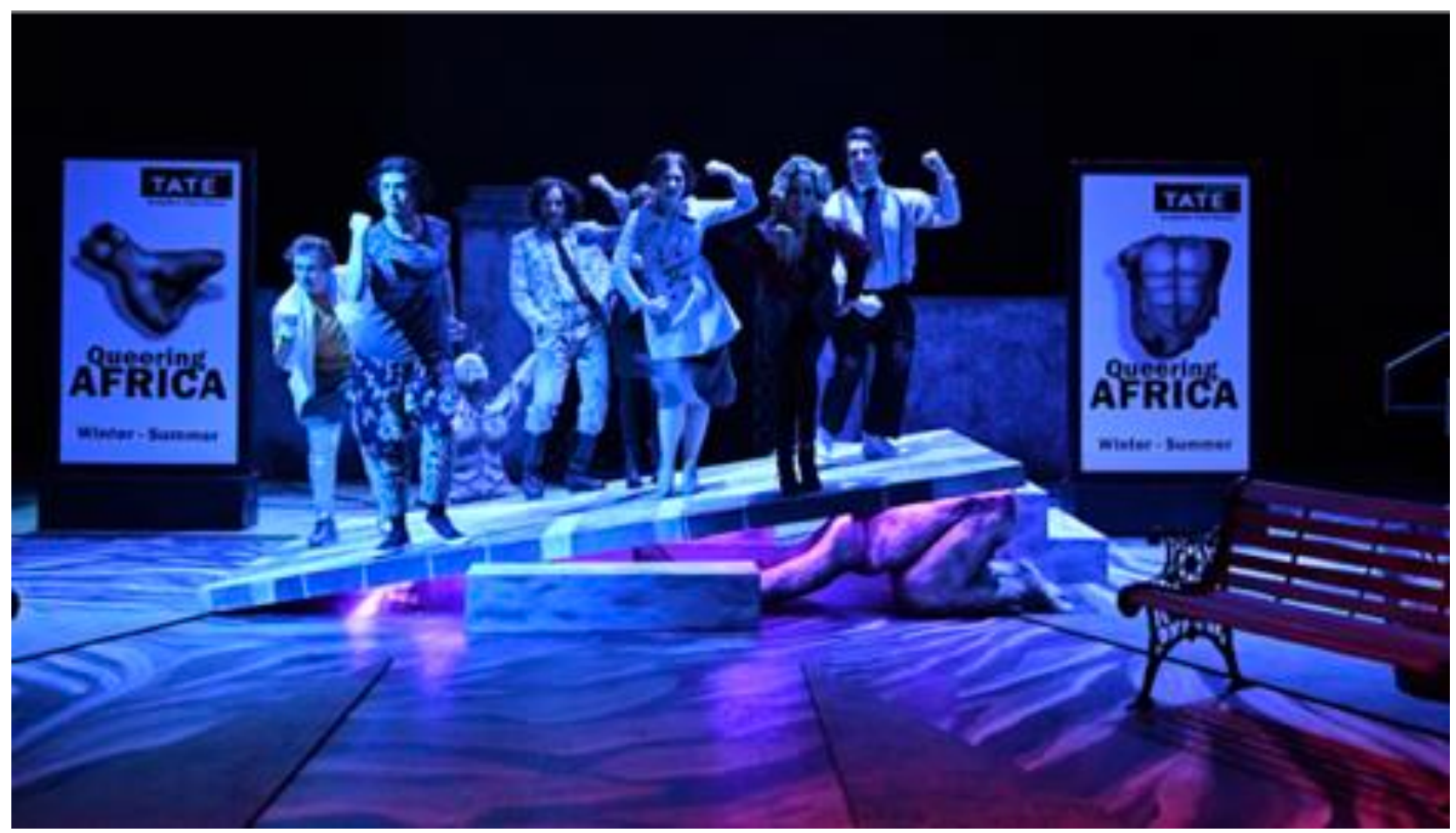

Figure 121: Act I to Act II transition

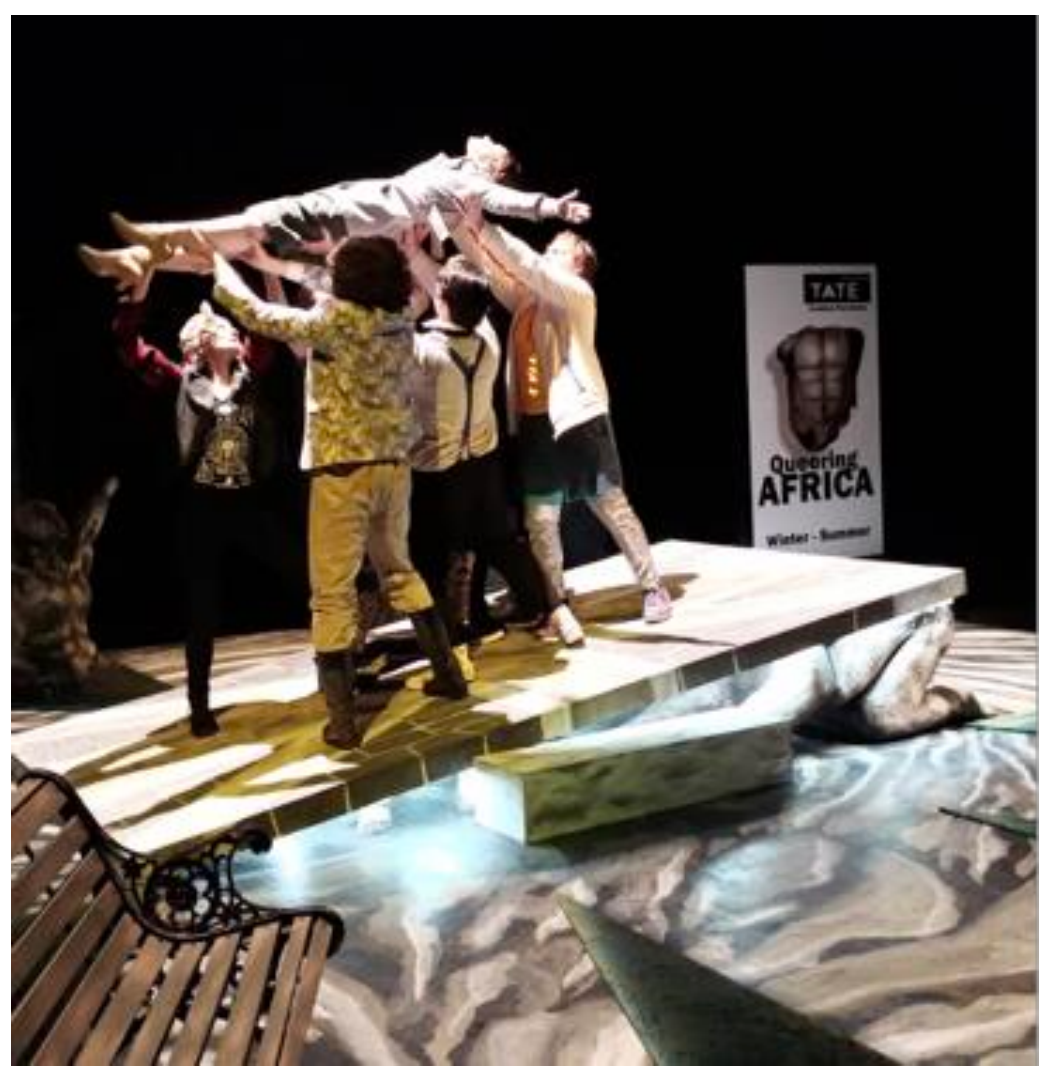

Figure 122: Act I to Act II transition 
A majority of the costume changes in the Act I of the show were made by the characters Mrs. Saunders and Ellen. As a character they shared a skirt, but had different blouses, wigs, and accessories. As first dress progressed, it became apparent that she was going to be unable to make her costume changes. In order to make her transitions between characters faster, the wig for the character of Ellen was cut from the show. The actress who plays Mrs. Saunders, Ellen, and Lin had a wig on for the entire run of the show, so her hair was up in pin curls under a wig cap. A mop cap was added in order to hide her wig cap. Not only did this speed up her costume changes, but it also made the character of Ellen appear dowdier which helped the character design. I had been hesitant to add a mop cap in my initial costume designs because I was afraid to make Ellen too frumpy, but overall this addition was beneficial to her character.

At the end of first dress, a discussion about the character Joshua arose. While he was wearing a slightly distressed suit, he still did not feel visually different in status from Clive. At this time, it was decided to remove his boots and have the actor be barefoot. Charcoal makeup was provided for the actor to distress his feet. This change visually lowered Joshua's station in the family.

It was decided during the second dress rehearsal that the costume of Victoria in Act II needed to change. Having designed her character based on "rave wear" she had a very eccentric wardrobe. Her apparel was often short and showed off her legs and stomach. To create a less extreme look her purple wig was exchanged for a medium brown wig. With the help of Professor Mary McClung, I pulled several new options for her character and we had an emergency fitting (Figures 123-125). Instead of bright colors and fitted clothing, the new Victoria had simpler patterns and soft pastel colors that emphasized her femininity without displaying her legs and midriff. This change strayed away from the inspiration of modern "rave wear" that I initially gravitated to. The visual transformation grounded the character. 


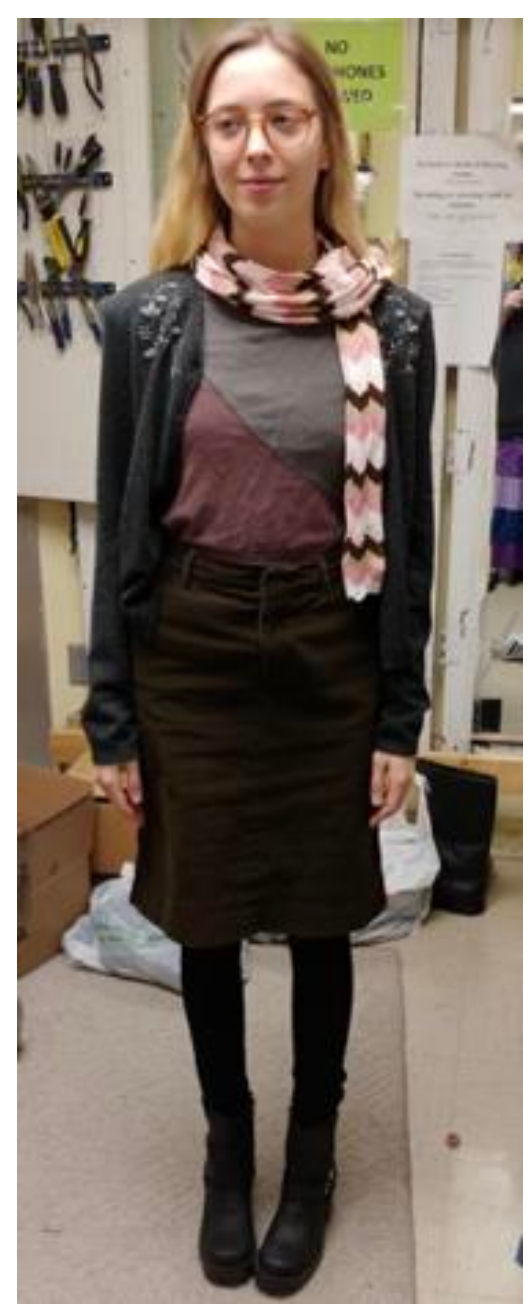

Figure 123: Emergency Victoria fitting

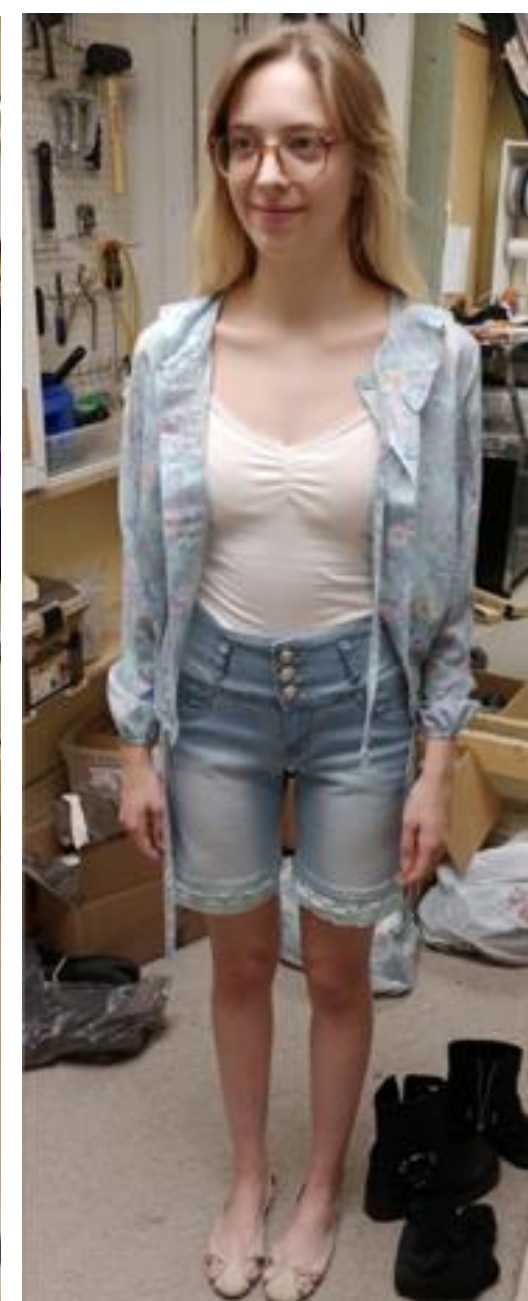

Figure 124: Emergency

Victoria fitting

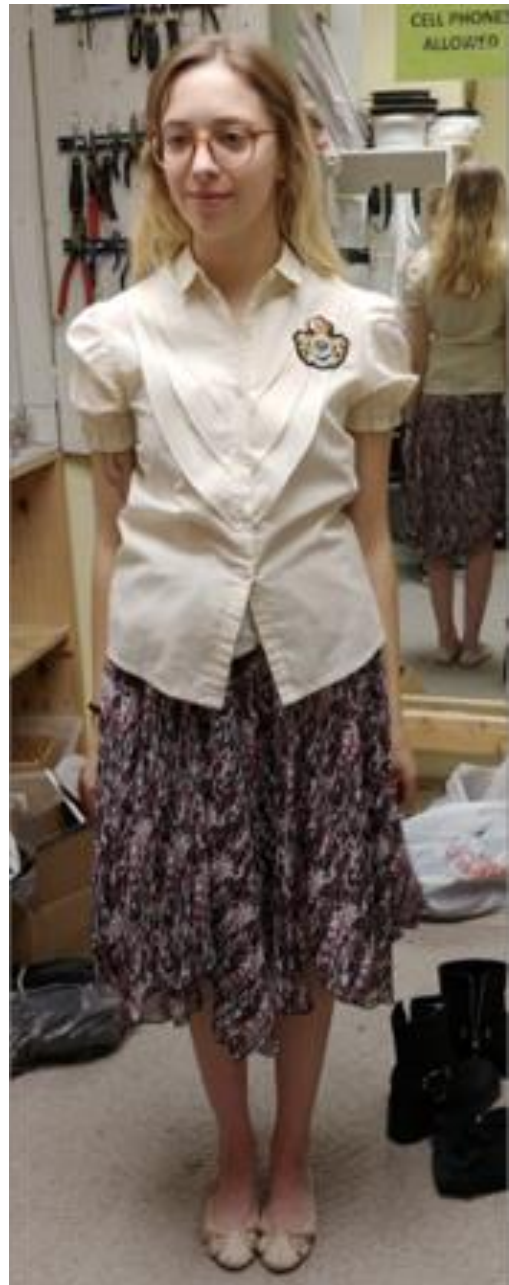

Figure 125: Emergency Victoria fitting

A problem faced in Act II was with the character Martin. During first dress we were unable to make it into Act II of the play. We had some trouble during wig training with the Martin wig and had to pull and style another. This new wig was fitted onto the actor. The problem with this particular wig started when the actor decided not to wear an ace bandage under the wig cap. The ace bandage is one way to secure a wig to heads with short hair. When discussing this with his dresser it was made apparent that wearing a wig this way was something 
the actor had not done before and it did not suit him. While the Joshua wig stayed on the actor, the wig for Martin had more hair and was heavier. Without something to secure it to, the wig would not stay in place. At one point during third dress, the actor removed the wig without the aid of their dresser and threw it in a chair. When we were unable to make the wig work at this time, it was cut from the production. 


\section{EVALUATION AND CONCLUSION}

This section addresses my reflections on the completion of the design of Cloud 9. I learned many ways in which I can improve my future designs through the discoveries made during this production.

Throughout the design process, my thoughts about each character evolved in many directions. At some point in time I started thinking of Ellen and Mrs. Saunders as completely separate characters and not characters played by the same actress. This was a major mistake on my part and resulted in complicating the costumes for the actress. I knew for certain the mistake I made when the cast sheet was released and both characters were played by the same actress. I can't say for certain why the separation happened in my brain, but I believe it was when I was listing qualities of each character to try and understand them better in the very early design process. I also do not look at other productions of a show when designing, in order not to be influenced by other designer's visions. After this mistake was already made, it was suggested to me that historical pieces that are produced often have analysis and literature written about them that would not hinder the design process. In the future I plan to incorporate reading more of the literature surrounding the play before designing to not make such a mistake again.

Communication is key. While at the time I felt I was communicating my ideas for the characters well, once the production moved into technical rehearsal it became evident that this was not always the case. I could have done a better job making sure that the Director was more a part of the costume process by providing images from fittings and having them come up to see the costume rack more often while garments were being completed. While discussing this with another designer, the advice offered to me was to make sure the stage manager has a copy of the costumes designs to reference in the rehearsal process. It is one thing to look at the costume designs in an office, but once the blocking begins it is good to have a visual to reference. This is 
something I have planned to implement in the future in order to help with the communication process.

One of the biggest problems literally facing the costumes while onstage was with the Scenic Design. Although we had previously met to discuss the use of rebar in the Scenic Design, it still posed a danger for the dresses and the actors in Act I. The rebar embedded into the figurative body pieces of the set and did not all go one direction, but every which way. This made it very difficult for the actresses in large dresses to be able to move on the set. When discussing this during first dress with the Scenic Designer, I pointed out four pieces of rebar that I found to be the most problematic for the costumes. During this conversation, I was interrupted by the Production Manager and my concerns about the rebar were discounted as it was basically said that they didn't have time to change it. Looking back, I understand that I should have put up more of an argument for the costumes, but at the time I felt highly uncomfortable. By the beginning of second dress, some of the blocking had been changed for characters such as Maud and Betty to help them avoid the spikes. While this was helpful for costumes, it still became the actor's responsibility to watch out for each other and make sure the dresses didn't get caught.

Pieces that were the most successful for the show were that of Harry Bagley in Act I, Edward in Act II , and Lin in Act II. Harry Bagley's costume really captured the essence of a rugged explorer (Figure 126). The suit he was forced to wear in the end of Act I, also worked well with the scene. With the addition of an ill-fitting top hat, the costumes worked to exaggerate the forced nature of the wedding (Figure 127). Edward's costumes in Act II also worked well because it transitioned through the act with the character's emotional development. In the second scene of Act II he is wearing long pants and a button-down shirt to garden in at the park (Figure 128). As he becomes more open with himself, he also wears more visibly relaxed clothing (Figure 129). Lin too, was a successful character throughout all of Act II. The slightly gothic 
tone of her costumes worked well with the actress' portrayal of the character (Figure 130 and Figure 131).

Pieces that were less than optimal were that of the characters Martin and Betty in Act II. The original costume designs for Martin were influenced by pseudo-intellectuals and modern hipster fashion. When it came to buying and fitting costumes on the actor playing Martin, I was unable to find certain pieces, like the striped pants (Figure 84) in the right size. This in addition to Martin's wig not working for the actor made the design fall flat.

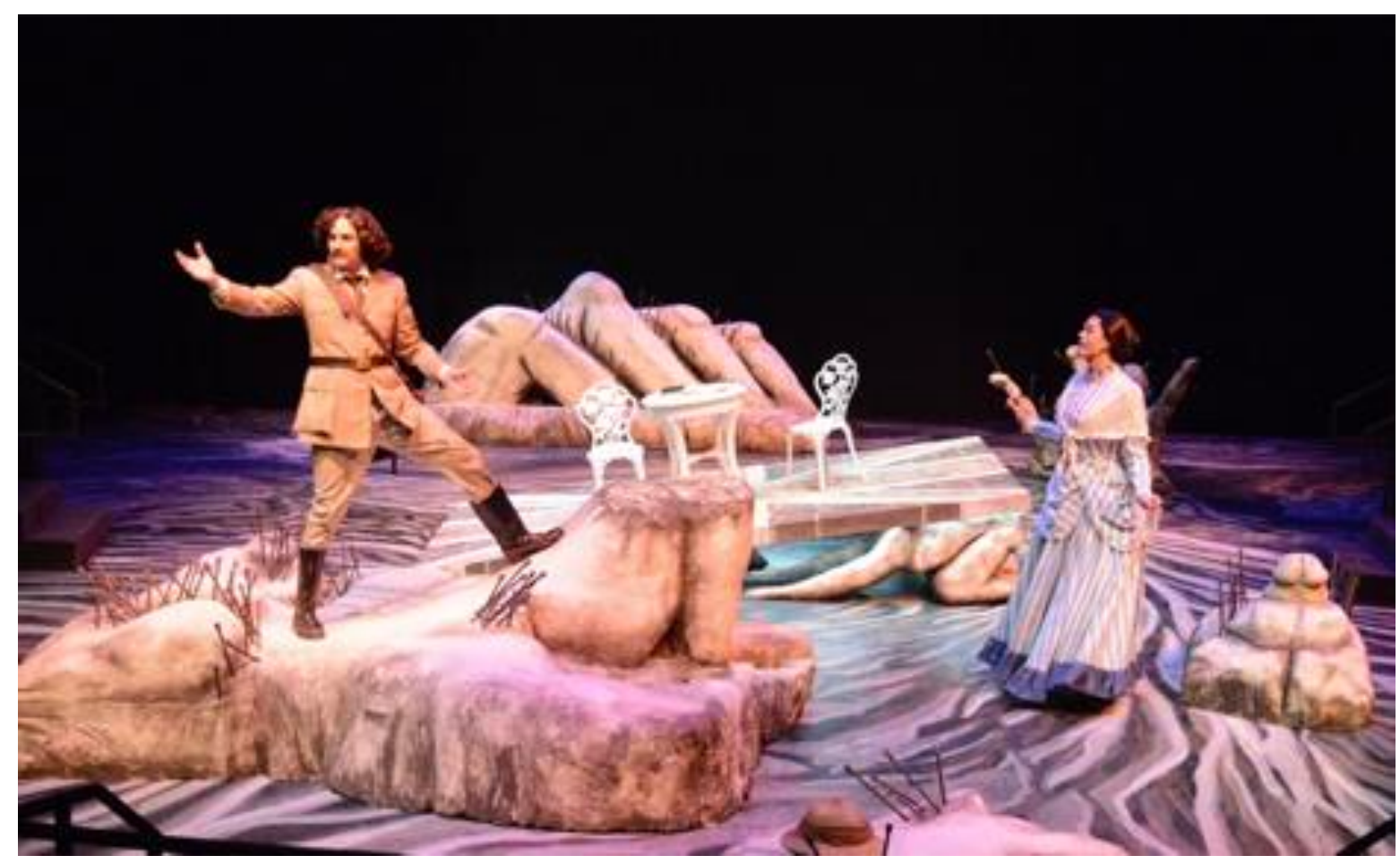

Figure 126: Harry Bagley 


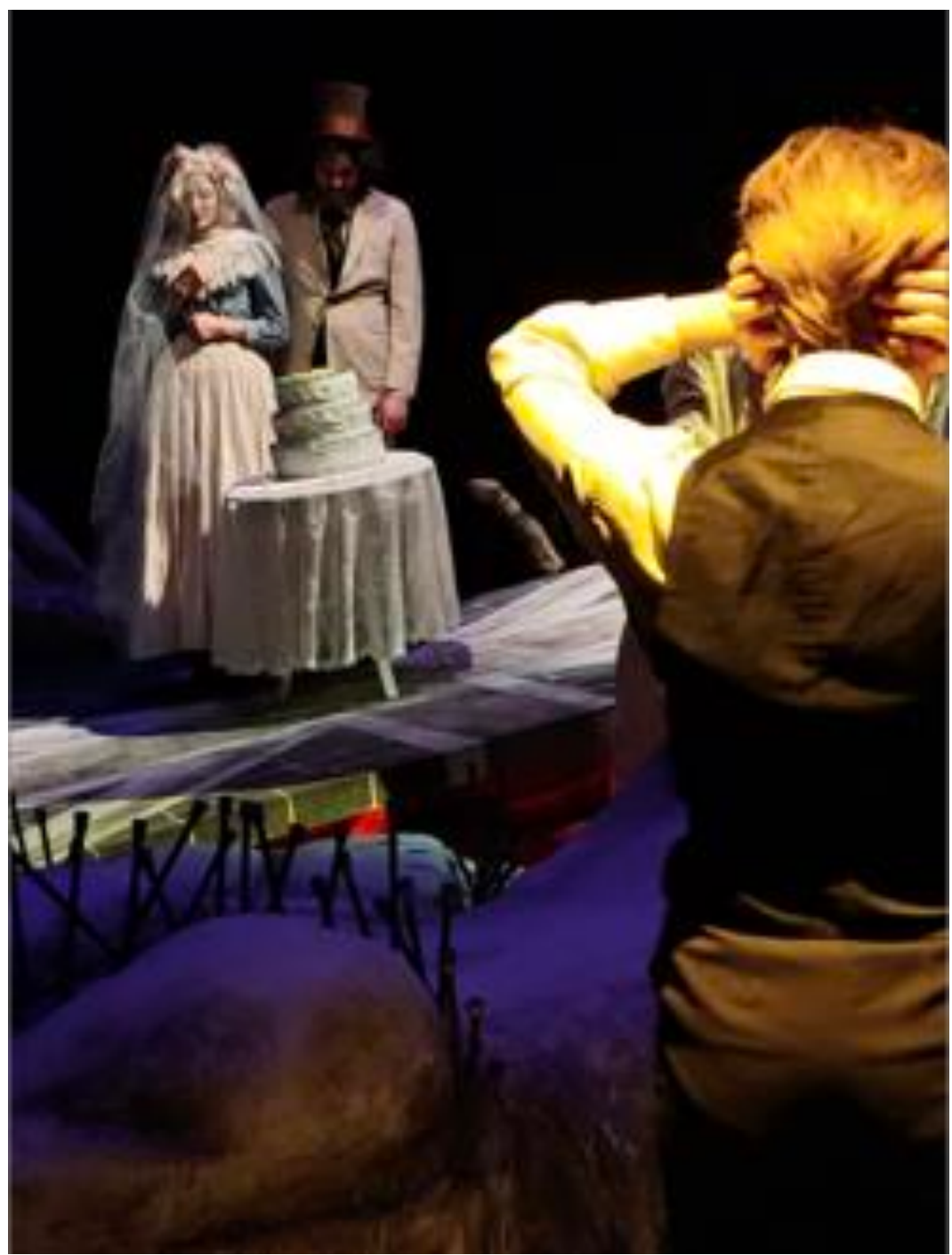

Figure 127: Harry Bagley Wedding

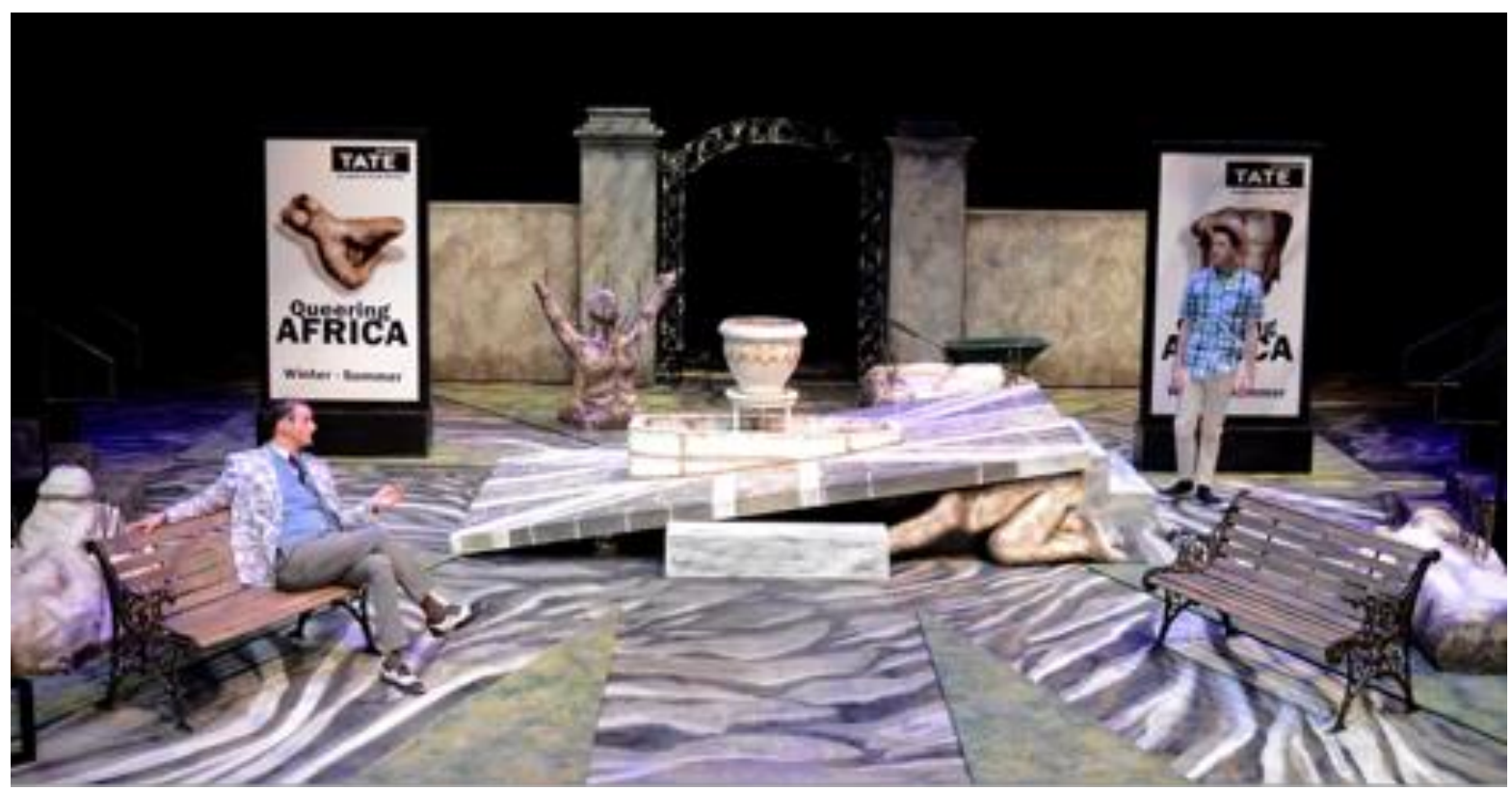

Figure 128: Edward in the Park 


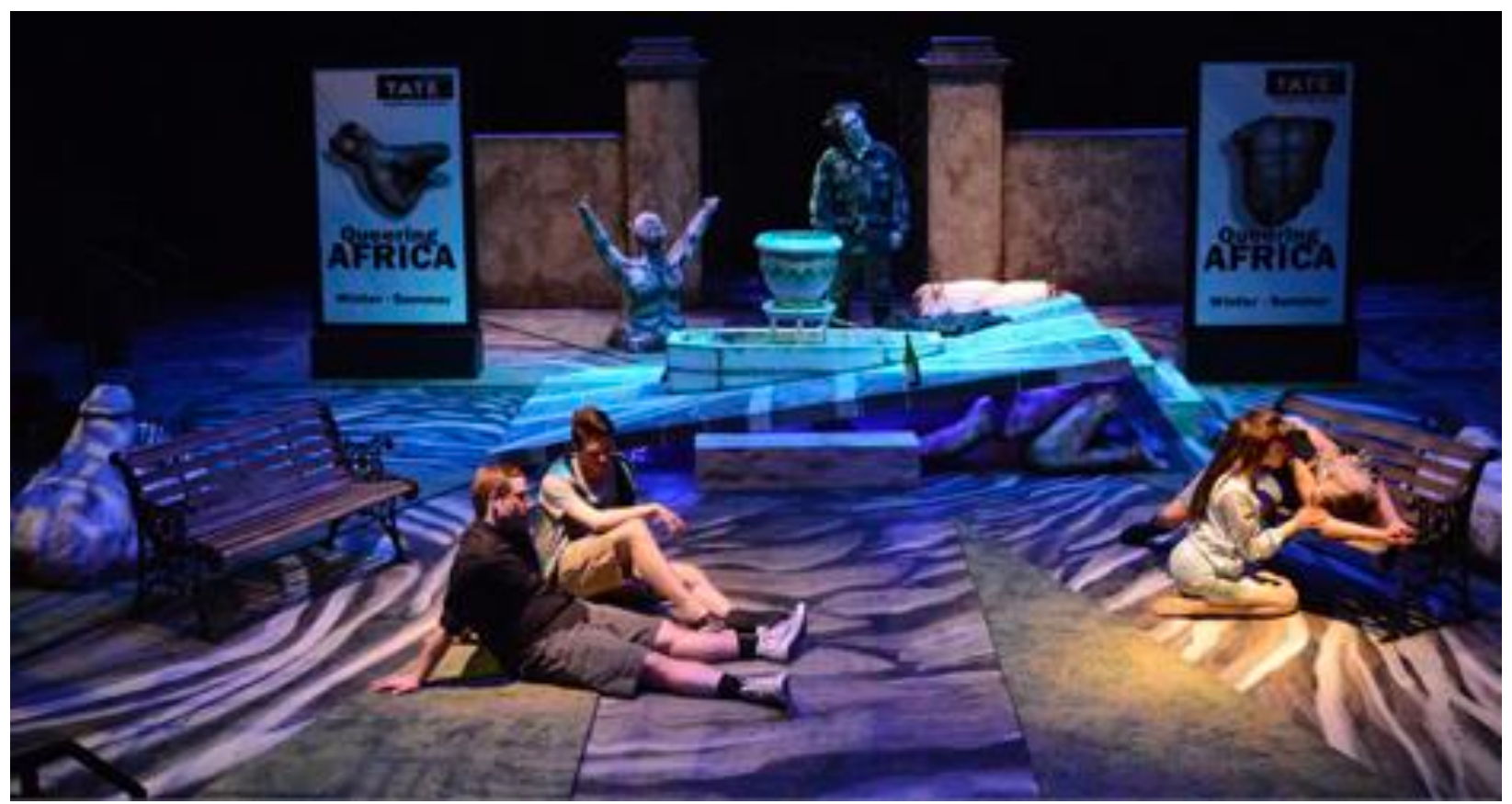

Figure 129: Edward in the Park

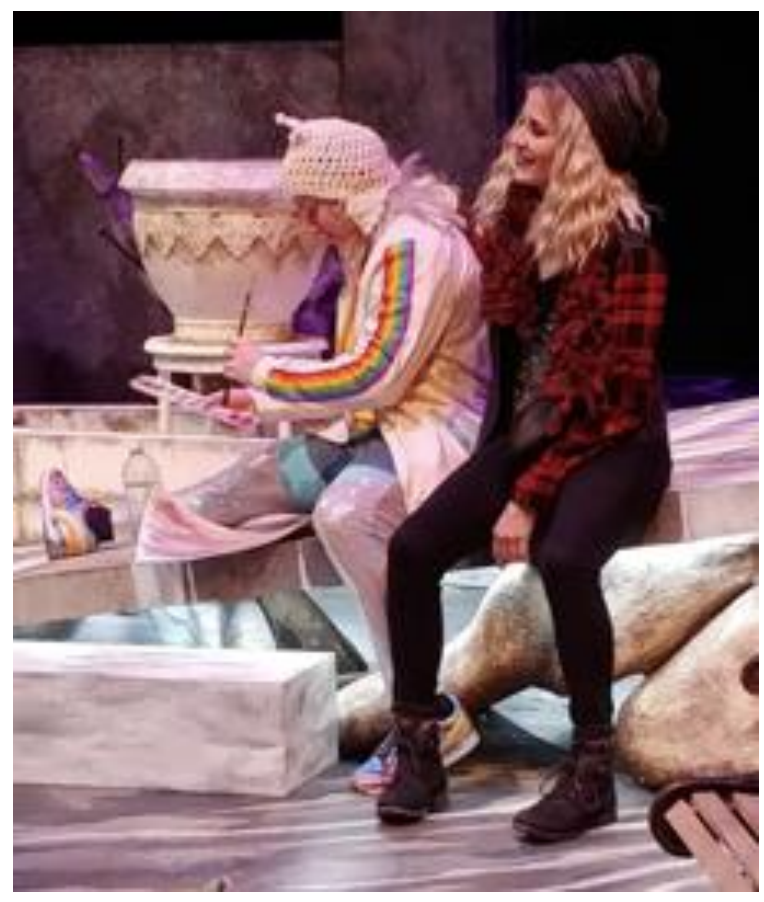

Figure 130: Lin and Cathy

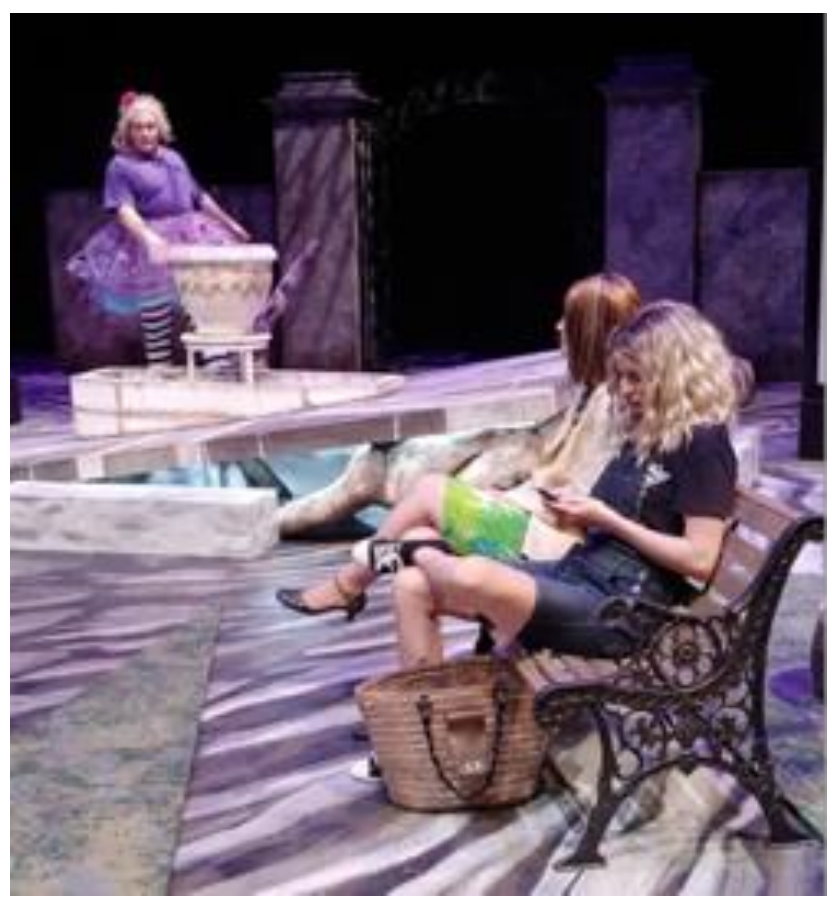

Figure 131: Lin and Cathy and Betty 
I also did not truly capture Betty's age in Act II. When buying costumes for Betty, I focused on finding items that were modern and fashionable. In doing so I choose items that were too closely fitted to the actress' body. Even with the addition of cardigans and age makeup, she still did not come across as an older woman. This is most evident in the final scene of Act II in the very a fitted yellow, floral dress she wears (Figure 132).

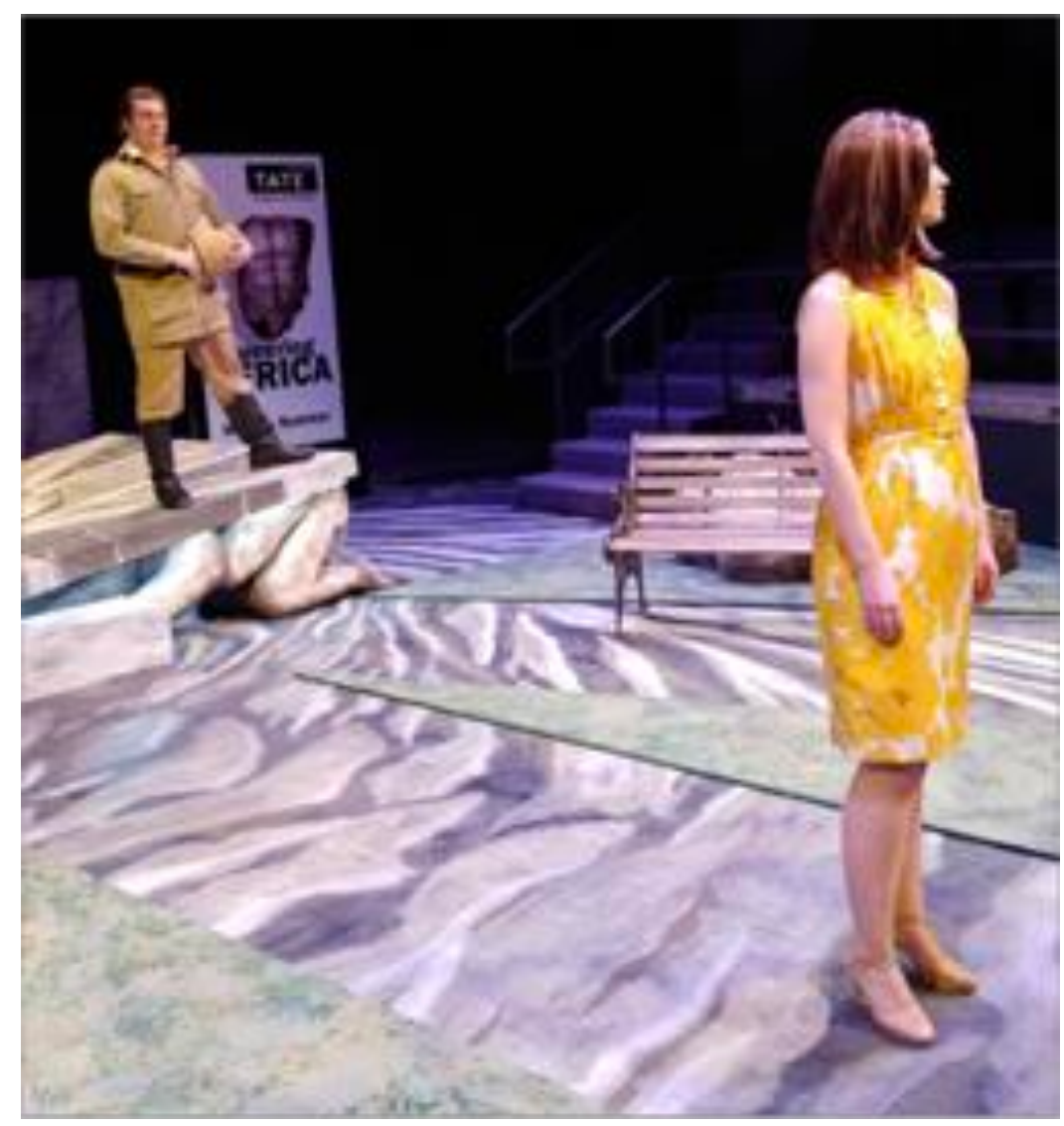

Figure 132: Betty Act II

Throughout the process it was imparted to me not to be emotionally invested into any one item in particular, as that is the item that is most likely to be cut from the production. This was very true in this show as well. The piece that I was hesitant to cut was the skirt built for Victoria in Act II with the celestial imagery foiled into the fabric. Through the rehearsal process it became evident that Victoria needed to change to make the show more successful and was eventually cut. 
If I were to do this production again, I would focus more on some of the small details I

overlooked. Such as in Act II, scene 1, I had Cathy wearing pants, a jacket, and a knitted hat. Yet during this scene Lin remarks about her smock and she wants to put on Betty's hat. Moments like these that I overlooked in the script were very painful to watch as an audience member. This production made me develop a more critical eye for accessory items that the characters wear. 


\section{EVALUATION OF THE PLAY}

Cloud 9 is an important piece of literary work to know, especially for those students who are pursuing theatre as a major. We had some trouble with audience members being vocal and disruptive during parts of the show. This was prevalent during Act II, during the "orgy scene" in the park. Hopefully some of the students who saw the show left with some questions about why they might be offended by same-sex couples, or maybe why some of their peers would be. Sometimes in theatre, because we work so closely together, it feels as if we live in a socially liberal bubble that is generally inclusive and accepting. Having people outside our bubble negatively react to situations that we believe to be normal, only shows that there is still a long way to go in our society before people with different identities are truly equal.

Cloud 9, while a prevalent piece of Caryl Churchill's work, has not aged as well into modern times. It brings up topics such as sexuality, feminism, self-acceptance, yet does not adequately give each of these topics the justice they deserve. Act II needs to be updated to better reflect the complexities of today. This can be especially seen in its treatment of race. While the Act I heavily shows the toxicity of white supremacy on the character of Joshua, Act II fails to address race at all. It is as if to say that racial discrimination is no longer a problem in modern day, something we know not to be true. The only racial comments mentioned are in Act II by Lin's brother who is anti-Irish. Not addressing race in the Act II undervalues the struggles of Joshua in the Act I.

Another topic that is just brushed past in the show is the problem of pedophilia. Harry Bagley, while being a queer man, is also a predator who preys on the young character of Edward. The reason I had a major problem with the treatment of this topic is that it perpetuates the myth that one becomes gay because of abuse they have faced in their past. This idea is still spouted by modern conservative media and is problematic to the advancement of queer rights. Edward is left somewhere on the queer spectrum in the Act II, being that what they identify as is unclear, gay or 
transgender. The abuse he faced as a child is never addressed by another character in the play, but is something the audience knows. Gerry, who is played by the same actor as Harry Bagley, has a moment in the park in Act II where he interacts with Edward from Act I who is a child. This is already a sexually charged scene as Gerry has just had a monologue about how easy it is to pick people up for sex in the park at night. The moment between Gerry and young Edward seems romantic as they discuss "What [they] did before" (Churchill 86). Churchills makes us watch the scenes with Harry and Edward, which is shocking for the audience. I found these moments to be very upsetting, increased by the fact that it felt like the script was condoning them.

The process of designing a show always has some moments that are more successful than others. I know there are some costumes that could have been implemented better to suit the characters. At the same time there are moments in the show that the costumes, set, and lighting worked together harmoniously. In Act I, there is a moment where it is just Joshua and Edward on stage in the early morning, and Edward is climbing all over the set. While rather simple, this moment highlights the lighting on the set and costumes beautifully (Figure 133 and Figure 134).

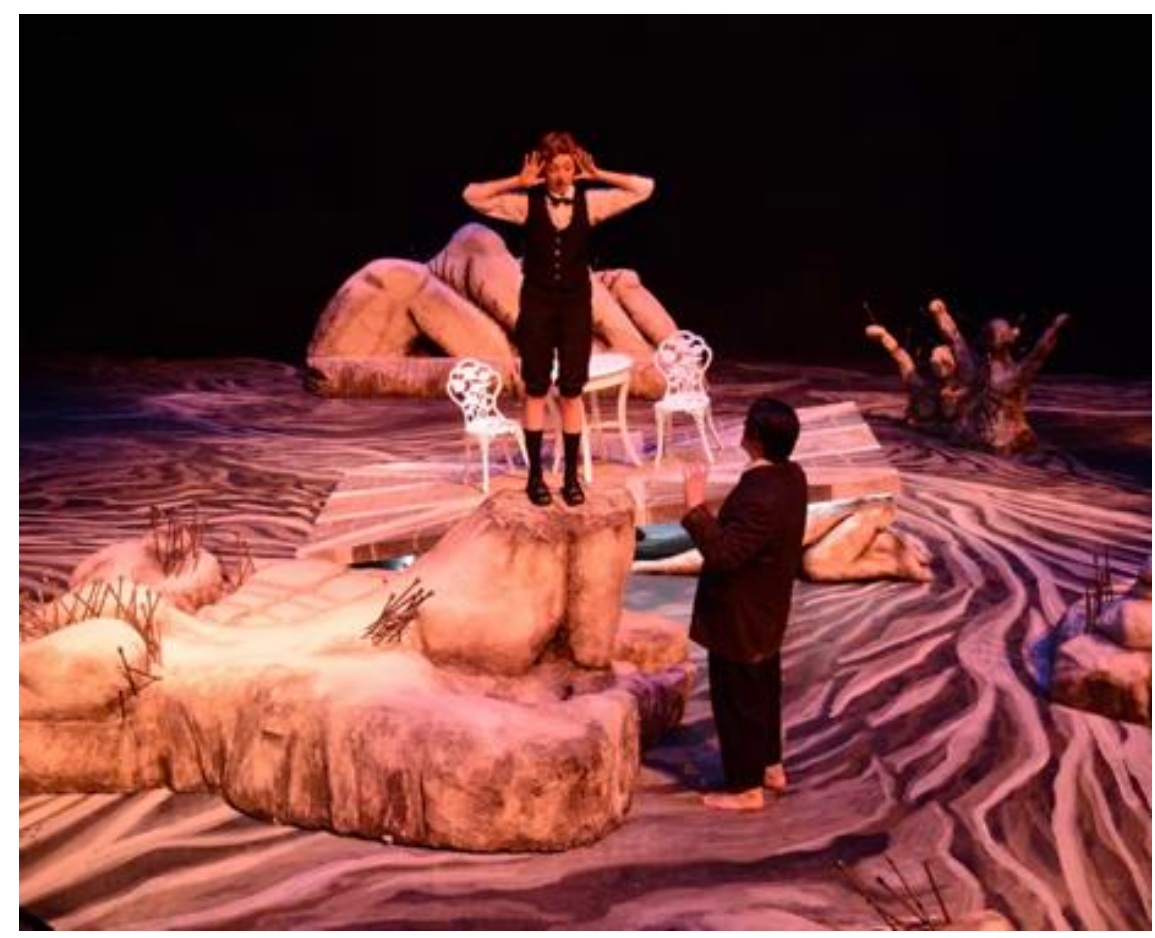

Figure 133: Edward and Joshua and the creation of the world 


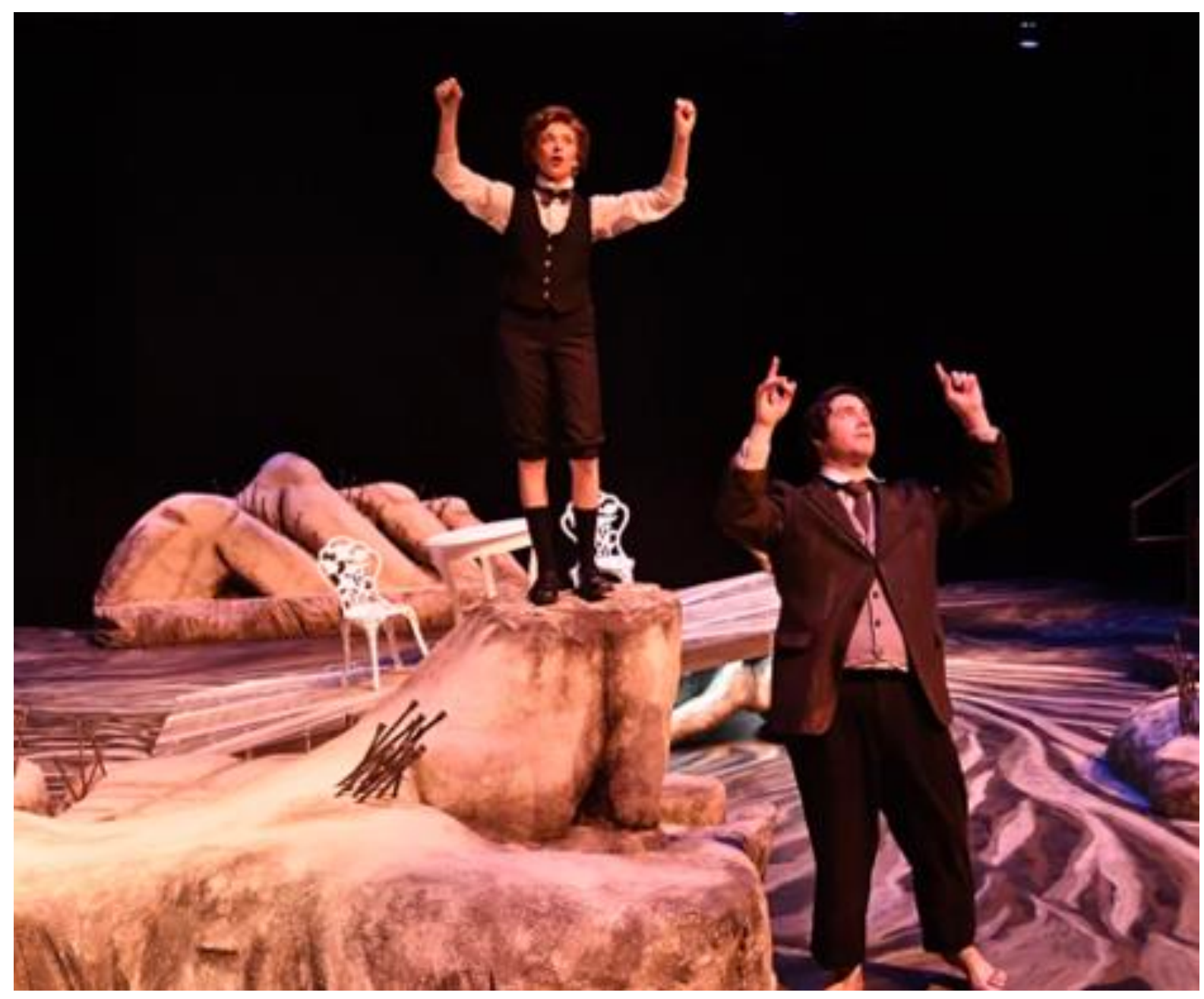

Figure 134: Edward and Joshua and the creation of the world 


\section{WORKS CITED}

Art and Culture. Postmodern Theatre - The Art and Popular Culture Encyclopedia, Art and Popular Culture, 2017, www.artandpopularculture.com/Postmodern_theater.

Churchill, Caryl. Cloud 9. Michel Kleinman Productions, 1981.

“Dosshaus.” DOSSHAUS, http://www.dosshaus.com/about-ba.

Hyland, Veronique. “Those 'Feminist' T-Shirts Might Not Be So Feminist.” The Cut, Vox

Media Network, 5 Nov. 2014, https:/www.thecut.com/2014/11/those-feminist-shirts-

might-not-be-so-feminist.html.

Imagawa, Misaki. "Minkisi - Power Figures \& Nail Fetishes from Central Africa.” Primitive

Living Collection, Primitive Inc., 8 Jan. 2016, http://www.beprimitive.com/blog/minkisi-

power-figures-and-nail-fetishes-from-central-africa.

Massey, Alana. “Vanity Fair Doesn't Understand What's Going on With Dating or

Tinder." Pacific Standard, A Mavan Channel, 13 Aug. 2015, https://psmag.com/social-

justice/cmon-thats-not-a-fuckboy-nancy-jo.

Pollack, Daniel. "Understanding Sexual Grooming in Child Abuse Cases.” American Bar Association, 1 Nov. 2015, www.americanbar.org/groups/public_interest/child_law/resources/child_law_practiceonlin e/child_law_practice/vol-34/november-2015/understanding-sexual-grooming-in-childabuse-cases/. 
Trifiro, Briana, "Instagram Use and It's Effect on Well-Being and Self-Esteem" (2018). Master of Arts in Communication. Paper 4. https://digitalcommons.bryant.edu/macomm/4 


\section{Figure Sources}

Figure 1

“A Space of Your Own Print." Paul Richmond Studio, Shopify, 2019, https://

paulrichmondstudio.com/products/a-space-of-your-own-print.

Figure 2

“A Space of Your Own Print.” Paul Richmond Studio, Shopify, 2019, https://

paulrichmondstudio.com/products/a-space-of-your-own-print. Figure 3

“Portraits.” Jakub Kujawa Art, Carbonmade, 2007, https://kujawa-art.carbonmade.com/ projects/4259547\#29.

Figure 4

Zielito. "Paregorics.” PPAREGORICS·, Tumblr, 6 Nov. 2013, https://

paregorics.tumblr.com/post/66183503452/red-lipstick-sophia-kamal-damansara- malaysia.

Figure 5

Godis, Ana. “Ana Godis on Instagram.” Instagram, 13 June 2019, https://

www.instagram.com/p/Bj9JhQxnA_6/.

Figure 6

Godis, Ana. "Ana Godis on Instagram: "(She's Not a Freemason, Honestly). . "Instagram, 12 June 2018, https:/www.instagram.com/p/Bj8M81LHag2/. 
Figure 7

Talbot, Charis. “Steampunkin'.” Charis Talbot Photography, Wordpress, 29 Apr. 2013,

https://charistalbotphotography.wordpress.com/tag/neo-victorian/.

Figure 8

Ifa. “TKF: Alice Auaa Fall 2013.” Pyoruru, Wordpress, 20 Mar. 2013, https://

pyoruru.wordpress.com/2013/03/20/tkf-alice-auaa-fall-2013/.

Figure 9

حسن آية. “،رض أزياء حسين بظاظا لخريف شتاء 2016 في دبي فانشن فورود ورحلة الخيميائية صوفيا.,, Apr. 2016, https://yummy.layalina.com/ffwd-hussein-bazaza-192596.html? lightbox_open=1.

Figure 10

Blaine, Elsa. "Futuristic Metallic Menswear.” TrendHunter.com, TREND HUNTER Inc., 29

Dec. 2008, https://www.trendhunter.com/trends/futuristic-metallic-menswear-antonin- tronsbronze-gold-nugget-jacket.

Figure 11

Dosshaus Builds Their Dream House Made Entirely out of Cardboard." Hi Fructose, Shrieking Tree, 25 Jan. 2016, https://hifructose.com/2016/01/25/dosshaus-builds-their- dream-house-madeentirely-out-of-cardboard/.

Figure 12

Fortson, Sara. "Three Exciting Shows at Corey Helford Gallery." Art and Cake, Word Press, 1 May 2018, https://artandcakela.com/2018/05/01/three-exciting-shows-at-corey- helford-gallery/. 
Figure 13

Bosch, Hieronymus. 1490-1510, Museo del Prado, Madrid.

Figure 14

Greenburg, Kerryn. “'African Adventure', Jane Alexander, 1999-2002.” Tate, Aug. 2013, https://www.tate.org.uk/art/artworks/alexander-african-adventure-t14629.

\section{Figure 15}

Lewis, Roy, and Yvonne Foy. Painting Africa White: the Human Side of British Colonialism. Universe Books, 1971.

Figure 16

Lewis, Roy, and Yvonne Foy. Painting Africa White: the Human Side of British Colonialism. Universe Books, 1971.

Figure 17

David Livingstone. 1860, London Stereoscopic \& Photographic Company, London .

\section{Figure 18}

Sharif, Al, and Raad Al Anbaky. "The Real American Heiresses Who Saved the British Aristocracy - Mary Leiter, Baroness Curzon." The Crown Chronicles, London Reign Communications Ltd, 1 Aug. 2016, https://thecrownchronicles.co.uk/history/historyposts/american-heiresses-saved-british-aristocracy-mary-leiter-baroness-curzon/. 


\section{Figure 19}

“All- Modern African Print Clothing.” D'IYANU, https://www.diyanu.com/collections/all/

men?page $=1 \&$ sort_by $=$ created-descending.

Figure 20

Plikerd, Laura. Rendering of Clive. 2018. Watercolor.

Figure 21

Plikerd, Laura. Rendering of Clive. 2018. Watercolor.

Figure 22

Plikerd, Laura. Rendering of Clive. 2018. Watercolor.

Figure 23

Plikerd, Laura. Rendering of Clive. 2018. Watercolor.

\section{Figure 24}

The Miriam and Ira D. Wallach Division of Art, Prints and Photographs: Picture Collection, The New York Public Library. "Walking-Dress ; House-Dress For Elderly Woman." The New York Public Library Digital Collections. 1889. http:// digitalcollections.nypl.org/items/510d47e0e4e7-a3d9-e040-e00a18064a99 


\section{Figure 25}

E., Sara. "Fashion from the 1880s." ...If He Did like Her, He Should Have Her..., Word Press, 25 Mar. 2012, https://historiful.wordpress.com/2012/04/07/fashion-from- the-1880s/.

\section{Figure 26}

Plikerd, Laura. Rendering of Betty. 2018. Watercolor.

Figure 27

Plikerd, Laura. Rendering of Betty. 2018. Watercolor.

Figure 28

Plikerd, Laura. Rendering of Betty. 2018. Watercolor.

Figure 29

Plikerd, Laura. Rendering of Betty. 2018. Watercolor.

Figure 30

Plikerd, Laura. Rendering of Betty. 2018. Watercolor.

Figure 31

Shonibare, Yinka. 2006, Sindika Dokolo African Collection of Contemporary Art.

Figure 32

Granger. “0052063 - HENRY MORTON STANLEY (1841-1904) and Sidi Mubarak Bombay (1820-1885) on the 1871 Expedition into Central Africa to Search for David Livingstone. Wood Engraving after Godefroy Durand, 1890.” Historical Picture Archive, 20/20 Software, 2019, https://www.granger.com/results.asp?image $=0052063$. 
Figure 33

Plikerd, Laura. Rendering of Joshua. 2018. Watercolor.

Figure 34

Connolly, Sybil. “Boy's Jacket and Vest, 1870-1874.” FIDM Museum Blog, 2010, https://

blog.fidmmuseum.org/museum/2010/06/boys-jacket-and-vest-18701874.html\#more.

\section{Figure 35}

Sunflower Siblings- 1800s Antique Photograph- Victorian Children- Manitowoc, WisconsinCDV Portrait- Photographer Hugo Klingholz.” Ephemera Obscura Collection, Shopify, 2019, https://ephemeraobscura.com/products/sunflower- siblings-1800s-antique-photograph-victorianchildren-manitowoc-wisconsin-carte-de- visite-cdv-portrait-paper-ephemera.

Figure 36

Plikerd, Laura. Rendering of Edward. 2018. Watercolor.

Figure 37

Plikerd, Laura. Rendering of Edward. 2018. Watercolor.

Figure 38

Plikerd, Laura. Rendering of Edward. 2018. Watercolor.

Figure 39

“Vintage Photos." LoveVintageDolls, 2019, http://lovevintagedolls.aloarquitectura.com/ vintage. 
Figure 40

An Extensive Study of the Victorian Era: Step Back into an Age of Paradox and Power; The

Victorian Age Was Not One, Not Single, or Simple. The Victorian Era, 1997, http://

www.avictorian.com/servants_nursery.html.

Figure 41

“LOT 217 COTTON DRESS with STRAWBERRY PRINT, 1863.” Whitakerauction, Smug

Mug Inc. , 2019, https://whitakerauction.smugmug.com/The-Helen-Larson- Private-

Collection/1870s-through-1890s/LOT-217-COTTON-DRESS-with- STRAWBERRY-PRINT1863/.

Figure 42

Museum, Albert, and Digital Media. "History of Fashion 1840 - 1900.” History of Fashion 1840

- 1900, Victoria and Albert Museum, Cromwell Road, South Kensington, London SW7 2RL.

Telephone 44 (0)20 7942 2000. Email Vanda@Vam.ac.uk, 11 July 2013,

http://www.vam.ac.uk/content/articles/h/history-of-fashion-1840-1900/.

\section{Figure 43}

Plikerd, Laura. Rendering of Maud. 2018. Watercolor.

Figure 44

Plikerd, Laura. Rendering of Maud. 2018. Watercolor. 
Figure 45

Oakes, Leimomi. “The HSM 2016: Challenge \#3: Protection.” The Dreamstress, 17 Feb.

2016, http://thedreamstress.com/2016/02/the-hsm-2016-challenge-3-protection/.

\section{Figure 46}

LovedayLemon. “At the Seaside with the Nursemaid.” Flickr, Yahoo!, 5 Sept. 2008, https://www.flickr.com/photos/lovedaylemon/2830619817/.

\section{Figure 47}

Sharif, Al, and Raad Al Anbaky. "The Real American Heiresses Who Saved the British Aristocracy - Mary Leiter, Baroness Curzon.” The Crown Chronicles, London Reign Communications Ltd, 1 Aug. 2016, https://thecrownchronicles.co.uk/history/historyposts/american-heiresses-saved-british-aristocracy-mary-leiter-baroness-curzon/.

\section{Figure 48}

“Hell on Wheels' Bread and Circuses.” IMDb, IMDb.com, https://www.imdb.com/title/ tt2037270/characters/nm1069800.

\section{Figure 49}

Plikerd, Laura. Rendering of Mrs. Saunders. 2018. Watercolor.

Figure 50

Plikerd, Laura. Rendering of Mrs. Saunders. 2018. Watercolor. 
Figure 51

Plikerd, Laura. Rendering of Mrs. Saunders. 2018. Watercolor.

Figure 52

Plikerd, Laura. Rendering of Ellen. 2018. Watercolor.

Figure 53

Plikerd, Laura. Rendering of Ellen. 2018. Watercolor.

Figure 54

Plikerd, Laura. Rendering of Ellen. 2018. Watercolor.

Figure 55

“Henry Morton Stanley Books.” Shakari Connection, 2008, https://

www.shakariconnection.com/henry-morton-stanley-books.html.

\section{Figure 56}

Holt, James A. "A Study of the British Officer on Active Service in South Africa 1899 - 1902." Military Sun Helmets, Word Press, 5 May 2012, http:// www.militarysunhelmets.com/2012/astudy-of-the-british-soldier-on-active-service-in- south-africa-1899-1902.

\section{Figure 57}

“Clayton." The United Organization Toons Heroes Wiki, https://

theunitedorganizationtoonsheroes.fandom.com/wiki/Clayton. 


\section{Figure 58}

Plikerd, Laura. Rendering of Harry Bagley. 2018. Watercolor.

Figure 59

Plikerd, Laura. Rendering of Harry Bagley. 2018. Watercolor.

Figure 60

Plikerd, Laura. Rendering of Harry Bagley. 2018. Watercolor.

Figure 61

Plikerd, Laura. Rendering of Harry Bagley. 2018. Watercolor.

Figure 62

"What to Wear: a Floral Skirt.” My Power Pose, Hello Brio, 28 July 2015, http://

mypowerpose.com/what-to-wear-floral-skirt/

\section{Figure 63}

Moneta, Caitlan. "Bright Monochromatic Suits for Everyone! | CBC Life.” CBCnews, CBC/Radio Canada, 4 July 2018, https://www.cbc.ca/life/style/bright-monochromatic- suits-foreveryone-1.4733677.

Figure 64

Plikerd, Laura. Rendering of Betty. 2018. Watercolor. 
Figure 65

Plikerd, Laura. Rendering of Betty. 2018. Watercolor.

Figure 66

Plikerd, Laura. Rendering of Betty. 2018. Watercolor.

Figure 67

Livingston, Justin. “Justin Livingston on Instagram: 'Festival Day Two Look." Instagram, Instagram, 15 Apr. 2017, https://www.instagram.com/p/ BS7Glh_Dhvo/.

\section{Figure 68}

Kirkpatrick, Emily. “Jeff Goldblum Is a Fashion Icon.” Page Six, Word Press, 18 Oct.

2018, https://pagesix.com/2018/10/18/jeff-goldblum-is-a-fashion-icon/.

\section{Figure 69}

“Westknits.” Deep South Fibers, 2019, https://www.deepsouthfibers.com/brands/

Westknits.html.

\section{Figure 70}

Plikerd, Laura. Rendering of Edward. 2018. Watercolor.

\section{Figure 71}

Plikerd, Laura. Rendering of Edward. 2018. Watercolor. 
Figure 72

Plikerd, Laura. Rendering of Edward. 2018. Watercolor.

Figure 73

Plikerd, Laura. Rendering of Edward. 2018. Watercolor.

Figure 74

“Topshop Skinny Rib Crop Tee.” Celebrity Fashionista, 30 May 2015, https://

celebrityfashionista.com/taylor-swift/topshop-skinny-rib-crop-tee/.

Figure 75

Muller, Marissa G. "Miley Cyrus' Furry Birthday Jacket Has Fashion History." MTV

News, 24 Nov. 2014, http:/www.mtv.com/news/2007811/miley-cyrus-birthday-outfit/.

Figure 76

Wasilak, Sarah. "All the Coachella Style You Have to See From Last Year's

Festival.” POPSUGAR Fashion, 14 Apr. 2016, https:/www.popsugar.com/fashion/photogallery/37244855/image/37260860/Danielle-Bernstein-wore-black-bodysuit-beneath-herbreezy-Love.

Figure 77

Plikerd, Laura. Rendering of Victoria. 2018. Watercolor.

Figure 78

Plikerd, Laura. Rendering of Victoria. 2018. Watercolor. 
Figure 79

Plikerd, Laura. Rendering of Victoria. 2018. Watercolor.

Figure 80

Plikerd, Laura. Rendering of Victoria. 2018. Watercolor.

Figure 81

Freyr. "PRINTS LOOK SO SEXY ON MEN Pic.twitter.com/EvtJqKgQIw.” Twitter, Twitter, 21 Oct. 2017, https://witter.com/sunfloweraidil/status/921756829880741888.

Figure 82

Dadds, Kimberley. “37 Times Benedict Cumberbatch Well And Truly Owned 2014." BuzzFeed, BuzzFeed, 3 Oct. 2018, https://www.buzzfeed.com/kimberleydadds/214-gotcumberbatched.

Figure 83

Plikerd, Laura. Rendering of Martin. 2018. Watercolor.

Figure 84

Plikerd, Laura. Rendering of Martin. 2018. Watercolor.

Figure 85

Plikerd, Laura. Rendering of Martin. 2018. Watercolor.

Figure 86

Short Hair Cut. https://i.pinimg.com/originals/62/d0/4e/

62d04eda853ce43ddf69e66c0357ae3d.jpg 
Figure 87

"Notorious RBG Womens T-Shirt.” Guerrilla Graphix, https:/guerillagraphix.com/ collections/t-shirts-womens/products/notorious-rbg-womens-t-shirt.

\section{Figure 88}

“Shop Equality Matters T-Shirts Online.” Spreadshirt, https://www.spreadshirt.com/men

equality matters t-shirts.

\section{Figure 89}

Yandoli, Krystie Lee. "The Powerful T-Shirt One Woman Wore To New York Fashion Week." BuzzFeed, BuzzFeed, 11 Sept. 2014, https://www.buzzfeed.com/krystieyandoli/ the-powerful-tshirt-one-woman-wore-to-new-york-fashion-week.

\section{Figure 90}

Moon Goth. https://I.pinimg.com/Originals/8b/

73/57/8b73579102417a6dd2cbbfa8abb53912.Jpg, 2019.

\section{Figure 91}

"How to Wear Platform Shoes." Glam Radar, http://glamradar.com/how-to-wear-

platform-shoes/.

Figure 92

Plikerd, Laura. Rendering of Lin. 2018. Watercolor. 
Figure 93

Plikerd, Laura. Rendering of Martin. 2018. Watercolor.

Figure 94

Plikerd, Laura. Rendering of Martin. 2018. Watercolor.

Figure 95

Plikerd, Laura. Rendering of Martin. 2018. Watercolor.

Figure 96

"The Hair Bow Factory Over the Top Lollipop Candy Tutu Dress Size 12-24 Months to Size 6." Etsy, https://www.etsy.com/sg-en/listing/157657004/the-hair-bow-factory-over- the-top.

Figure 97

“Girls Dresses Cotton Casual Children Clothing Autumn Spring Baby Girl Dress Long Sleeve Girls Party Dresses Big Kids Clothes.” Bajby.com, https://bajby.com/products/ 9611572.

Figure 98

Plikerd, Laura. Rendering of Cathy. 2018. Watercolor.

Figure 99

Plikerd, Laura. Rendering of Cathy. 2018. Watercolor.

Figure 100

Plikerd, Laura. Rendering of Cathy. 2018. Watercolor. 
Figure 101

“Arme Chimique En Irak.” - Blog, https://felixducharme.weebly.com/blog/ october-15th-2014.

Figure 102

Rakshasa. "Captain America Video: How Captain America Was Able To Use Thor's Hammer In Avengers: Endgame.” Fanpop, http://www.fanpop.com/clubs/captain-

america/videos/42826335/title/how-captain-america-able-use-thors-hammer-avengers- endgame

Figure 103

“\$510, Fratelli Borgioli Handmade Brown Italian Leather Wingtip Oxford

Shoes." Lookastic, https://lookastic.com/men/tan-leather-oxford-shoes/shop/handmade- brownitalian-leather-wingtip-oxford-shoes-2830.

\section{Figure 104}

Jr, Robert Marshall. "Dior Homme Continues to Reinvent the Black Suit for 2017 Fall/ Winter." HYPEBEAST, HYPEBEAST, 21 Jan. 2017, https:/hypebeast.com/2017/1/dior- homme-2017fall-winter-collection-paris-fashion-week.

Figure 105

Plikerd, Laura. Rendering of Gerry. 2018. Watercolor.

Figure 106

Plikerd, Laura. Rendering of Gerry. 2018. Watercolor.

Figure 107

Plikerd, Laura. Rendering of Gerry. 2018. Watercolor. 
Figure 108

Plikerd, Laura. Fitting Photo. 2018. Photograph.

Figure 109

Plikerd, Laura. Fitting Photo. 2018. Photograph.

Figure 110

Plikerd, Laura. Fitting Photo. 2018. Photograph.

Figure 111

Plikerd, Laura. Fitting Photo. 2018. Photograph.

Figure 112

Plikerd, Laura. Fitting Photo. 2018. Photograph.

Figure 113

Plikerd, Laura. Fitting Photo. 2018. Photograph.

Figure 114

Plikerd, Laura. Primary Budget Sheet. 2018. Numbers Document.

Figure 115

Plikerd, Laura. Budget Sheet. 2018. Numbers Document. 
Figure 116

Plikerd, Laura. Puppet Photo. 2018. Photograph.

Figure 117

Maiorano, Lindsey. Cloud 9 Photo. 2018. Photograph.

Figure 118

Plikerd, Laura. Process Photo. 2018. Photograph.

Figure 119

Plikerd, Laura. Fitting Photo. 2018. Photograph.

Figure 120

Plikerd, Laura. Photo of Cloud 9. 2018. Photograph.

Figure 121

Plikerd, Laura. Photo of Cloud 9. 2018. Photograph.

Figure 122

Maiorano, Lindsey. Cloud 9 Photo. 2018. Photograph.

Figure 123

Plikerd, Laura. Fitting Photo. 2018. Photograph.

Figure 124

Plikerd, Laura. Fitting Photo. 2018. Photograph. 
Figure 125

Plikerd, Laura. Fitting Photo. 2018. Photograph.

Figure 126

Maiorano, Lindsey. Cloud 9 Photo. 2018. Photograph.

\section{Figure 127}

Plikerd, Laura. Fitting Photo. 2018. Photograph.

Figure 128

Maiorano, Lindsey. Cloud 9 Photo. 2018. Photograph.

Figure 129

Plikerd, Laura. Fitting Photo. 2018. Photograph.

Figure 130

Plikerd, Laura. Photo of Cloud 9. 2018. Photograph.

Figure 131

Maiorano, Lindsey. Cloud 9 Photo. 2018. Photograph.

Figure 132

Plikerd, Laura. Fitting Photo. 2018. Photograph.

Figure 133

Maiorano, Lindsey. Cloud 9 Photo. 2018. Photograph. 
Figure 134

Maiorano, Lindsey. Cloud 9 Photo. 2018. Photograph. 


\section{Appendix A: Additional Images}

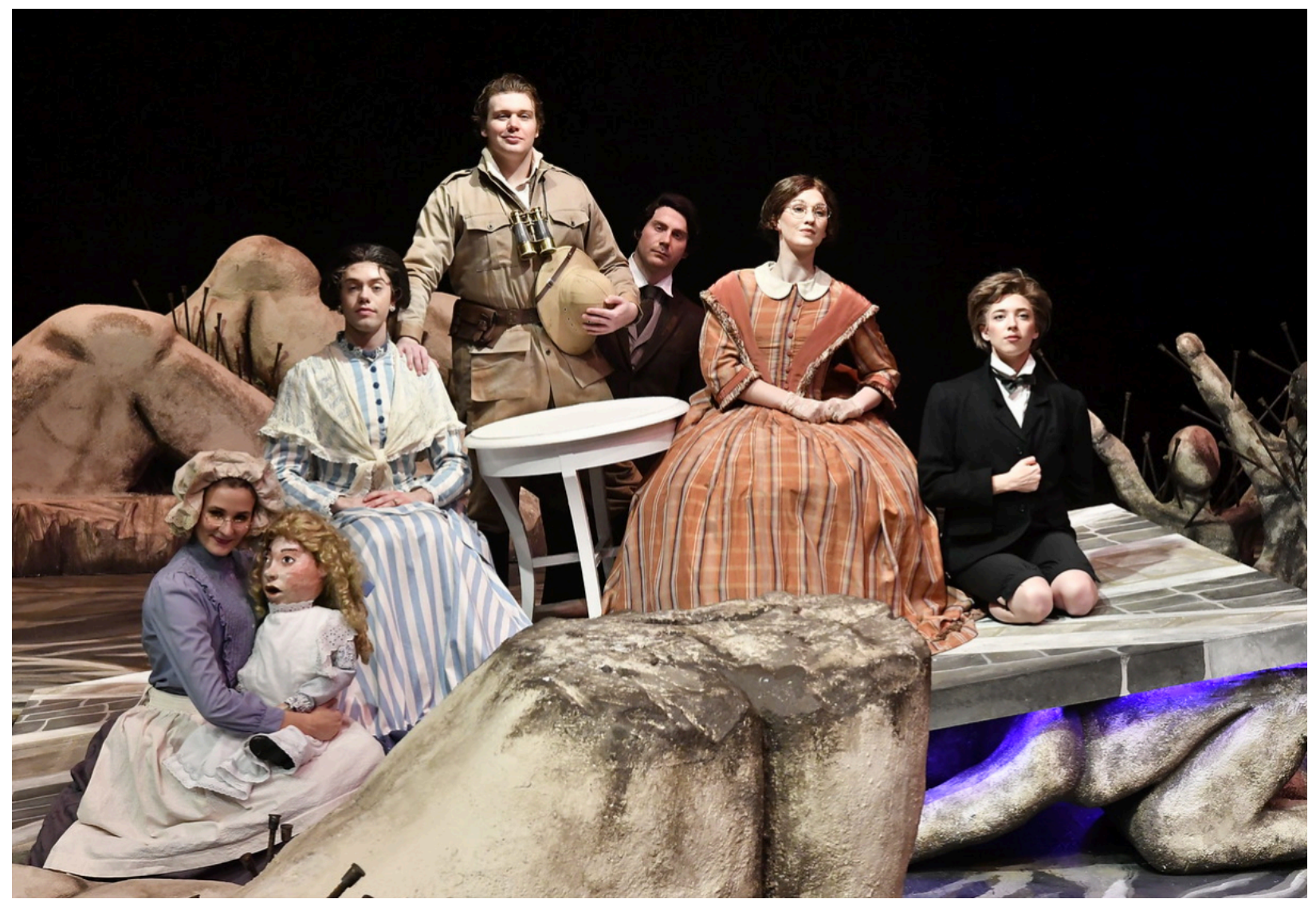

Figure 124: Act one, family photo

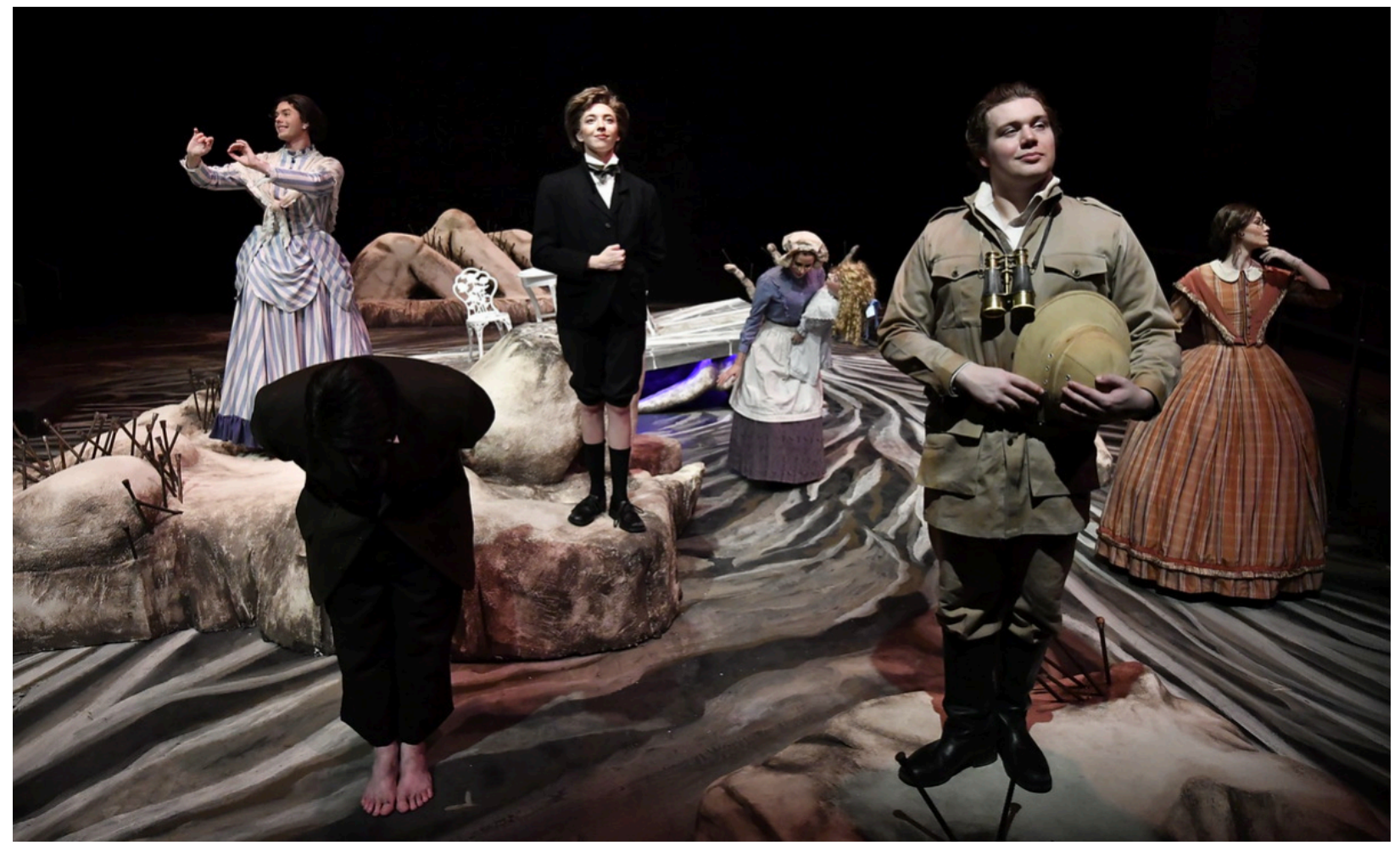

Figure 125: Act one, family photo 


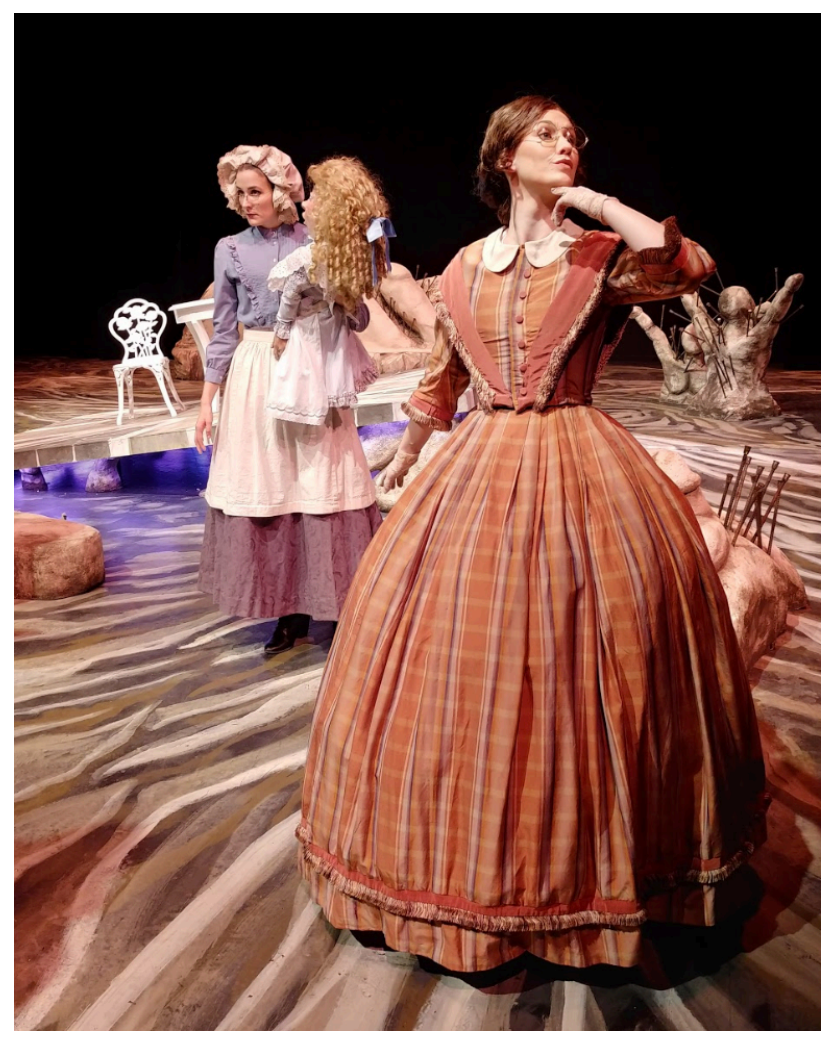

Figure 126: Act one, Maud, Ellen, and young Victoria

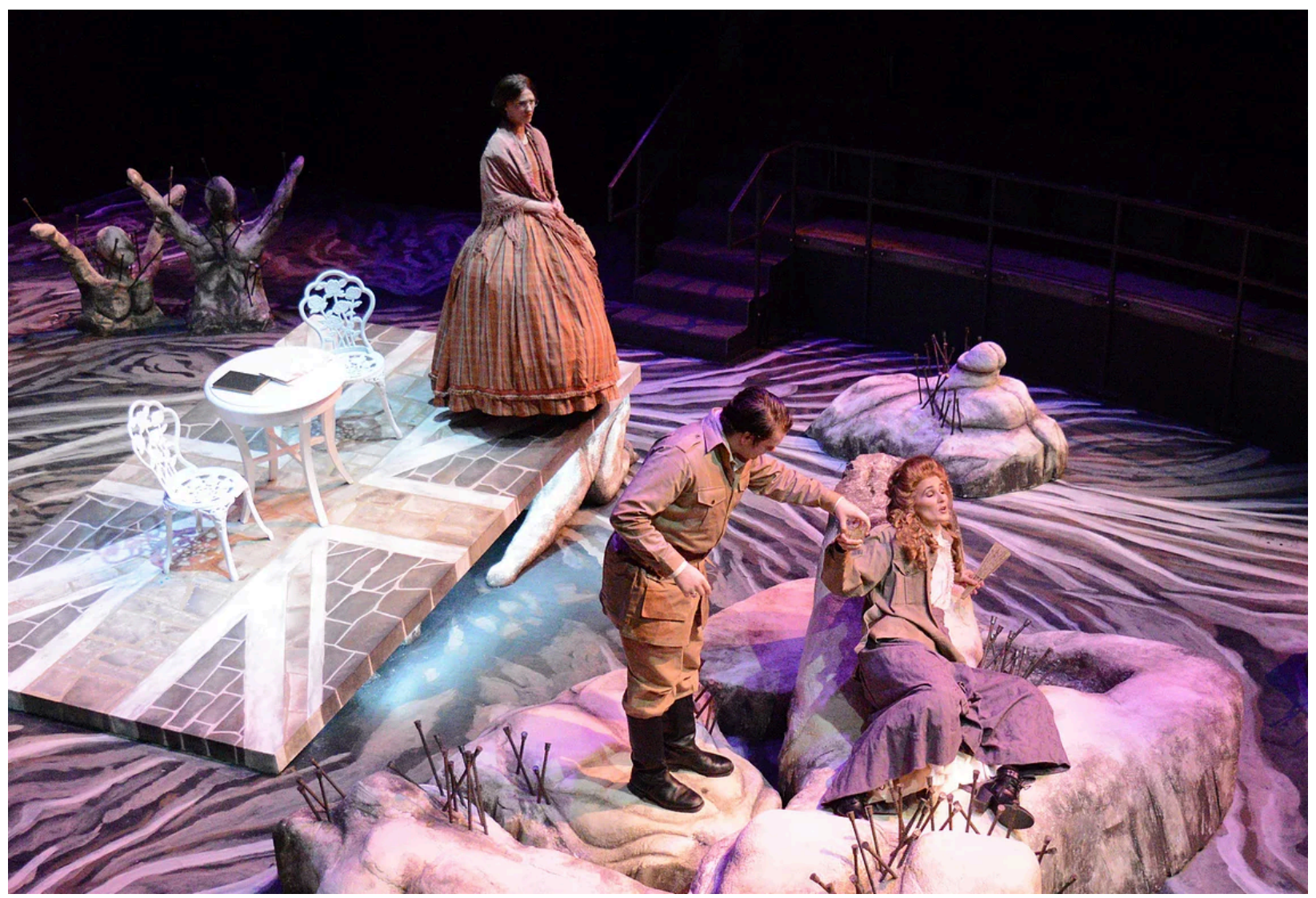

Figure 127: Act one, the introduction of Caroline Saunders 


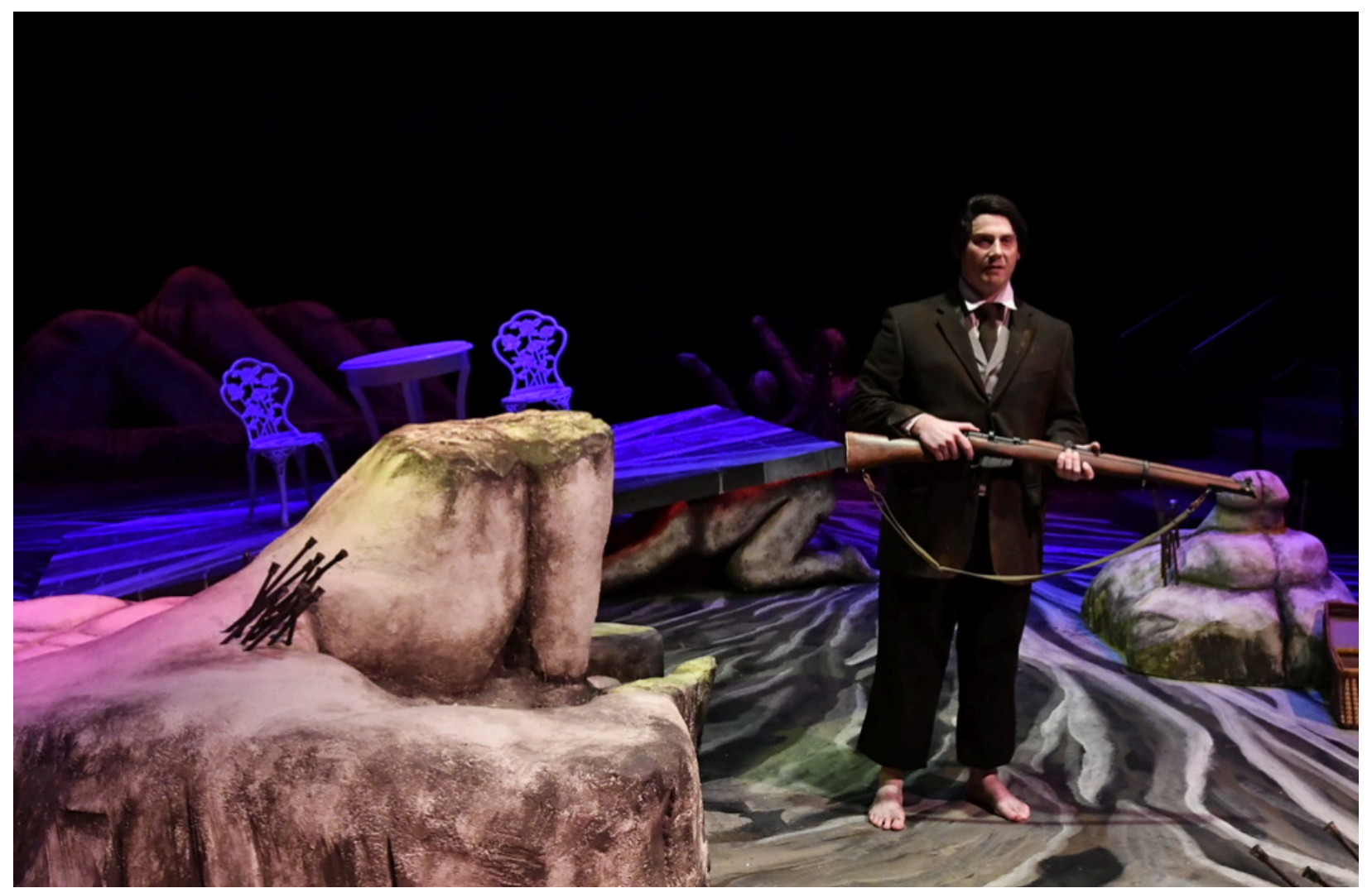

Figure 128: Act one, Joshua alone

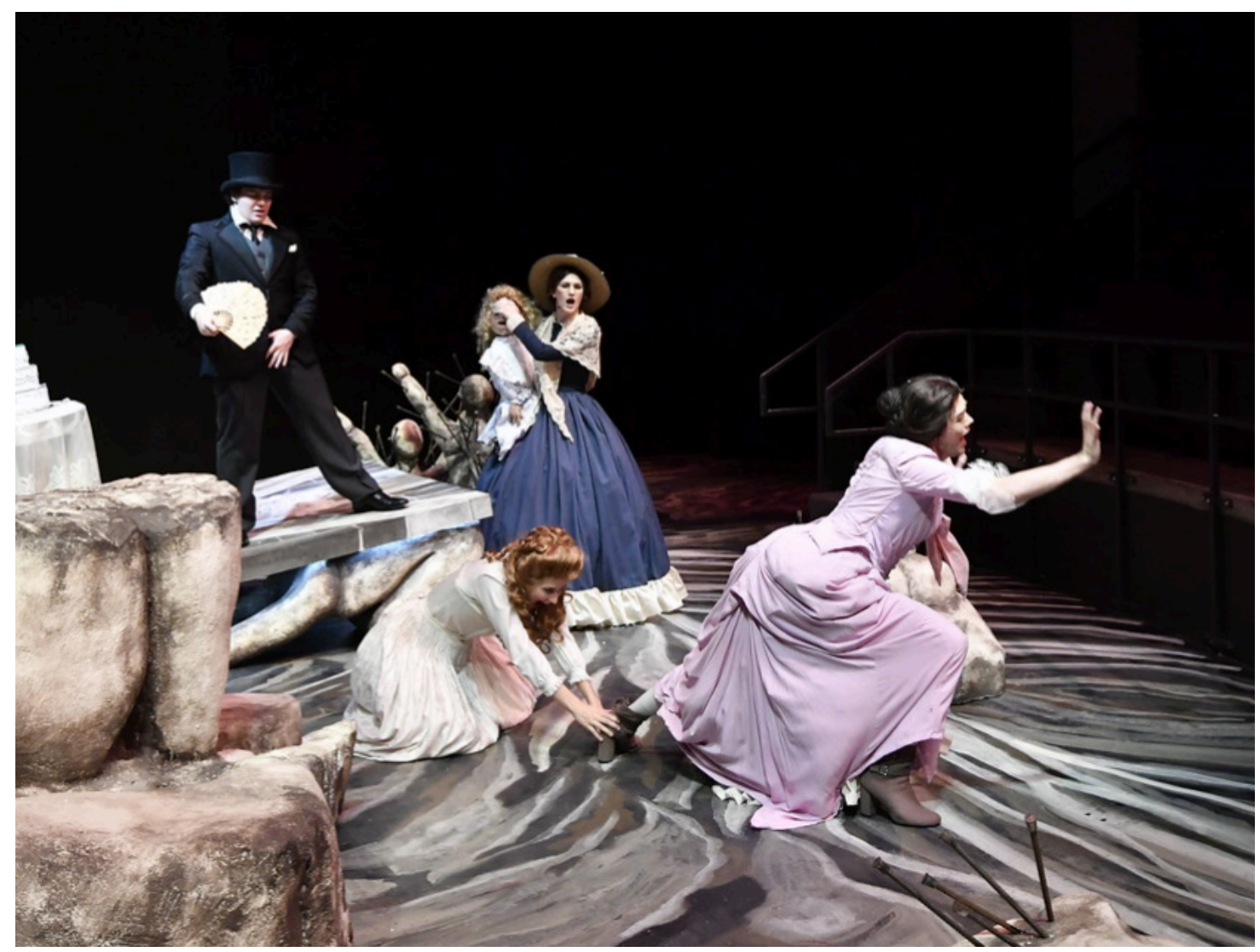

Figure 129: Act one, wedding fight 


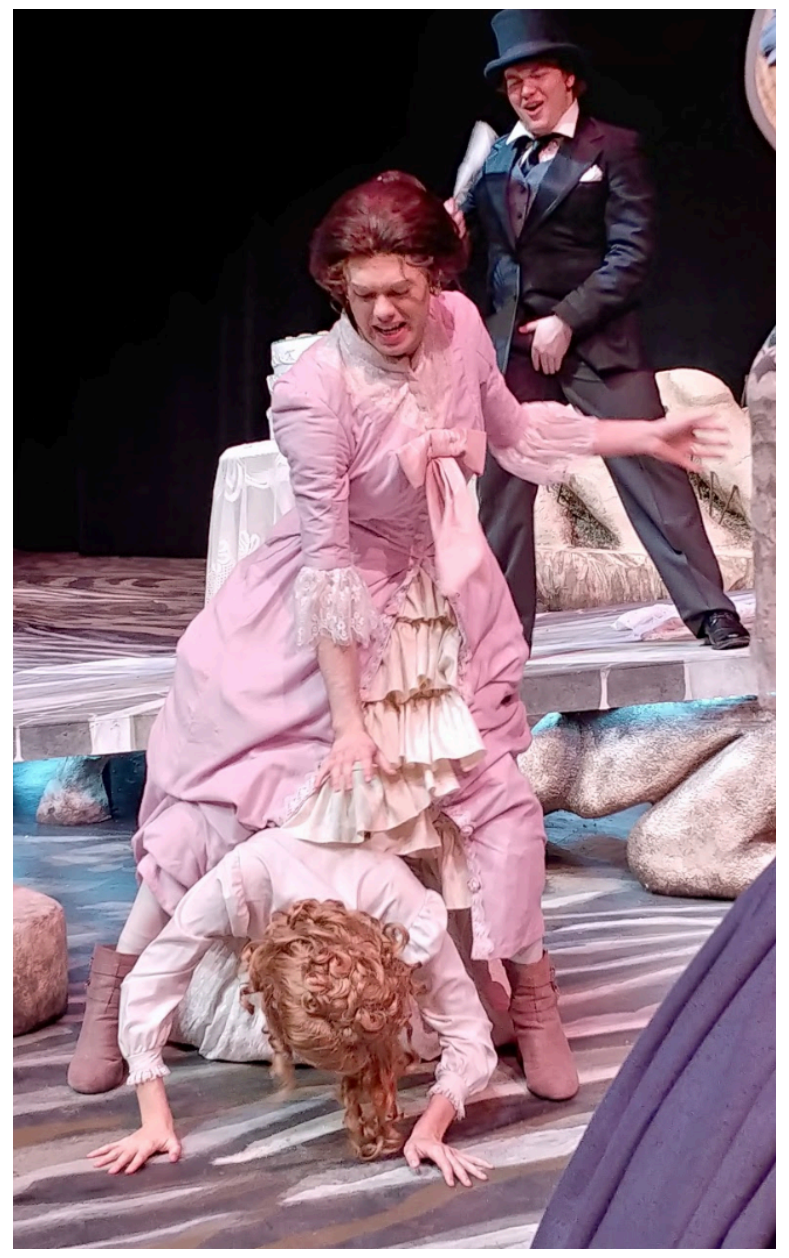

Figure 130: Act one, wedding fight

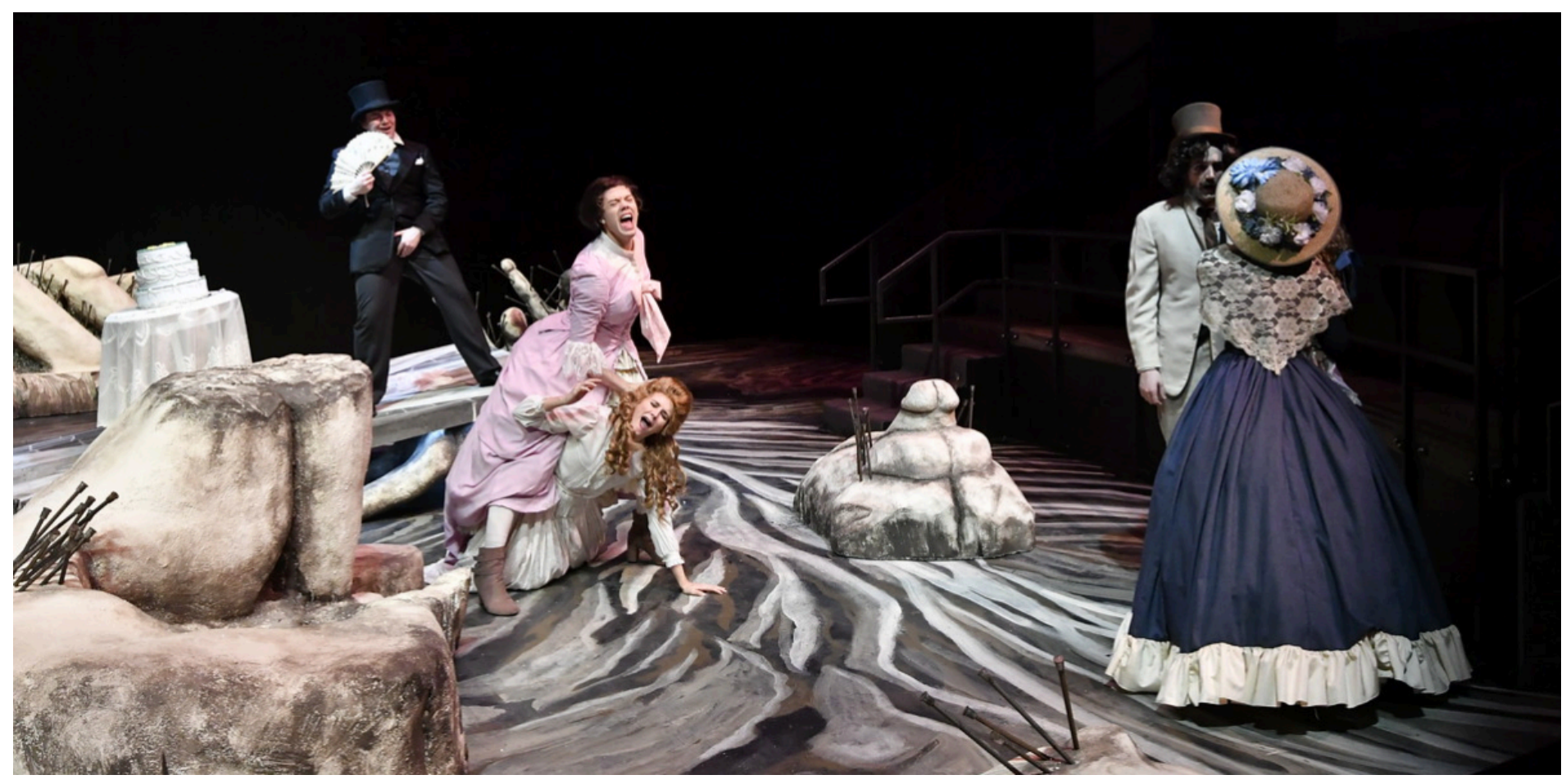

Figure 131: Act one, wedding fight 


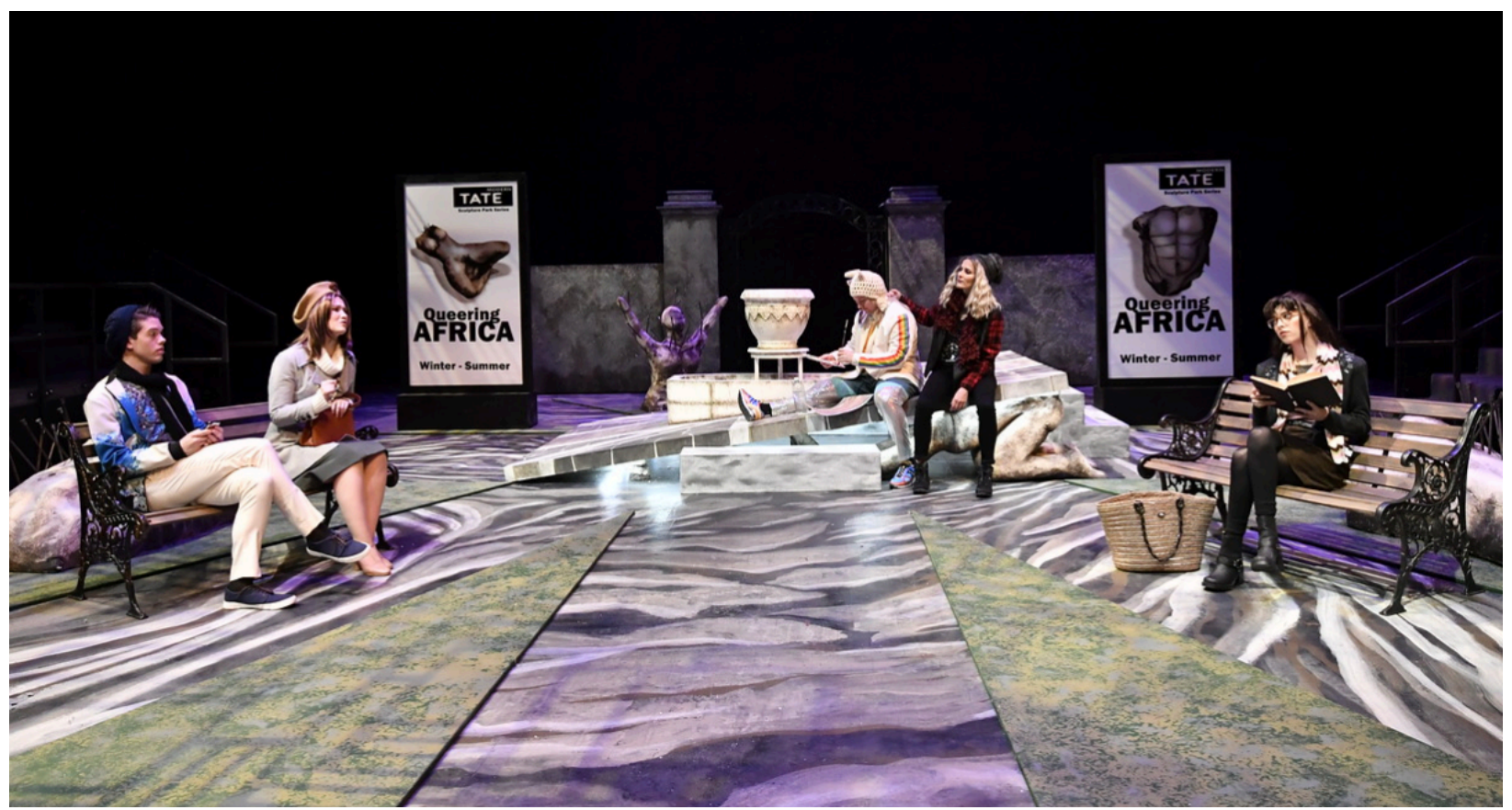

Figure 132: Act two, park

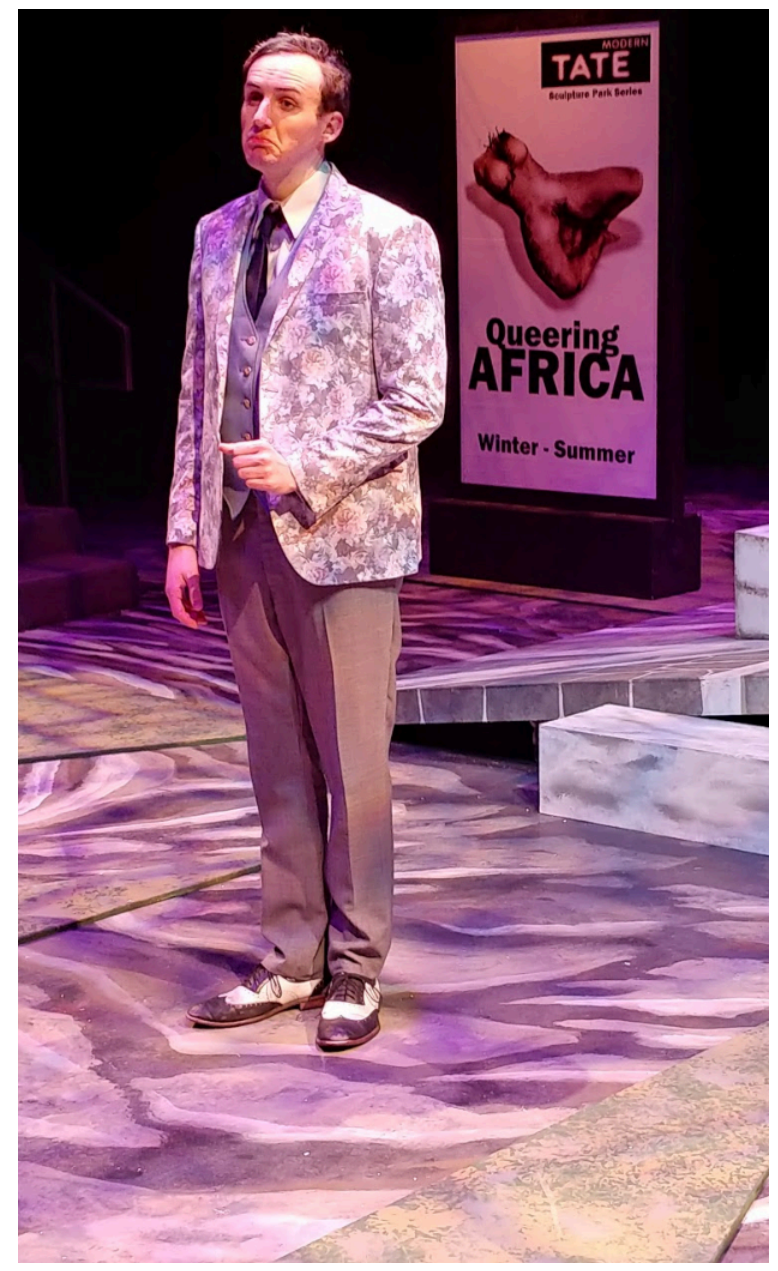

Figure 133: Act two, Gerry 


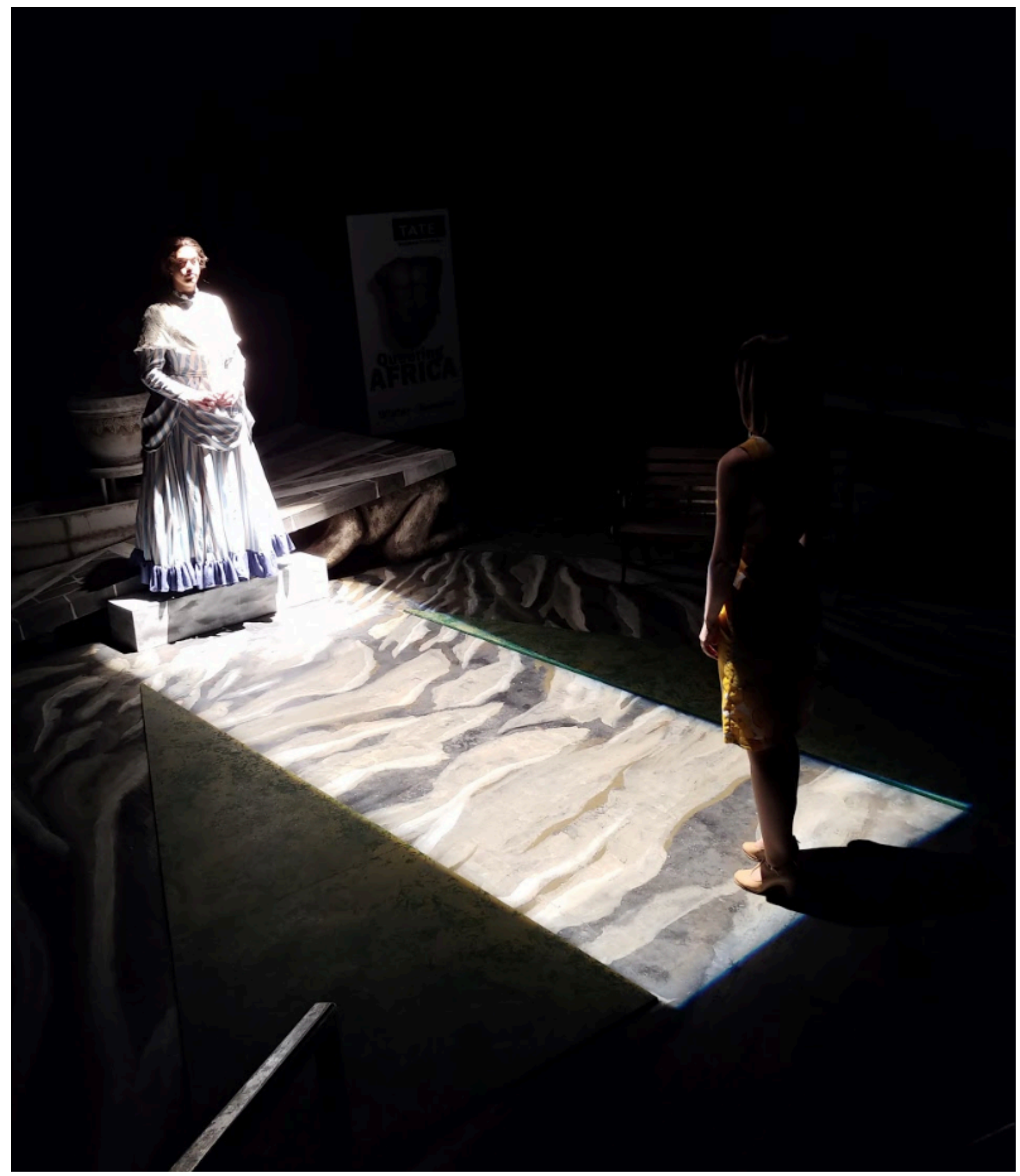

Figure 134: Act two, Betty meets Betty 
Appendix B: "Look Books"

\section{Cloud Nine}

Clive

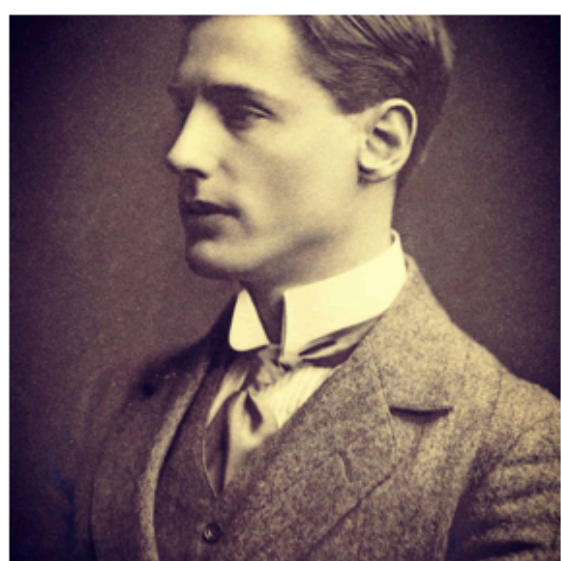

Research Image 1

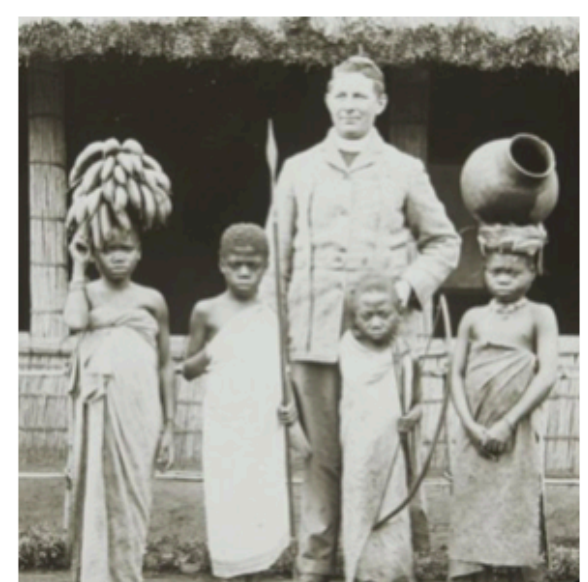

Research Image 2

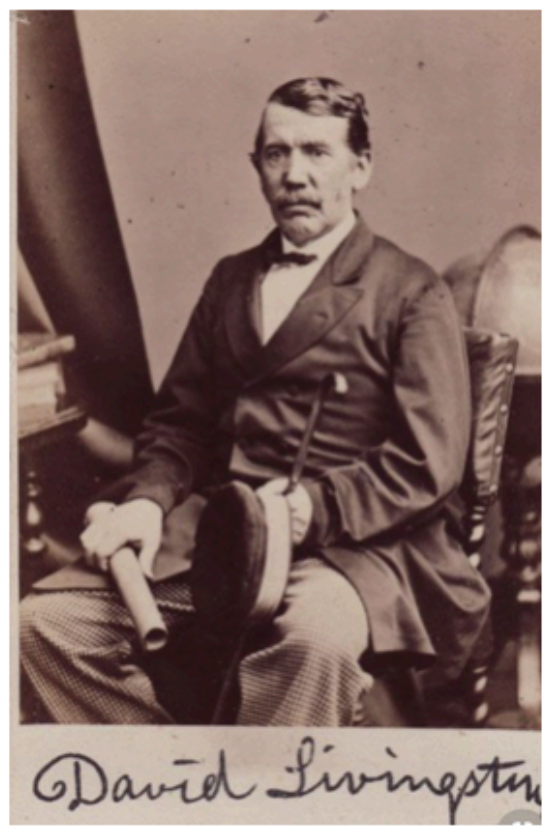

Research Image 5

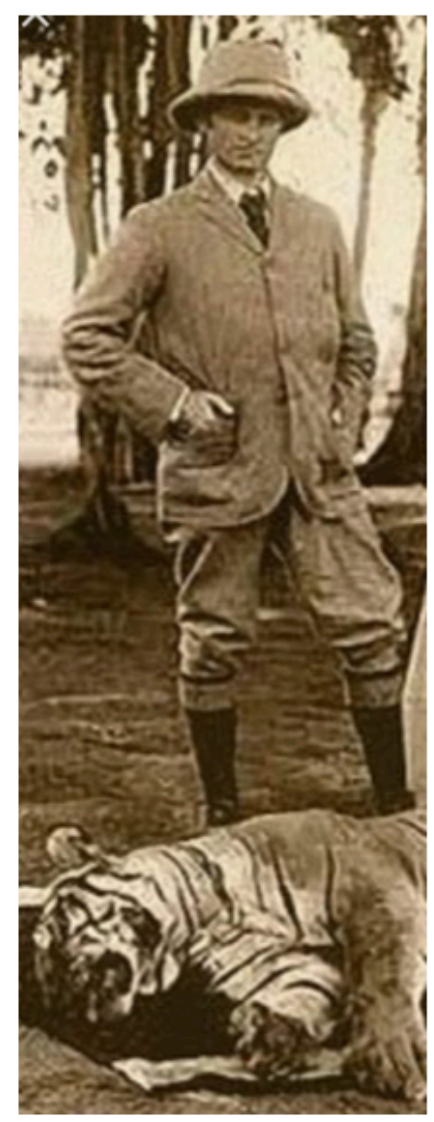

Research Image 3

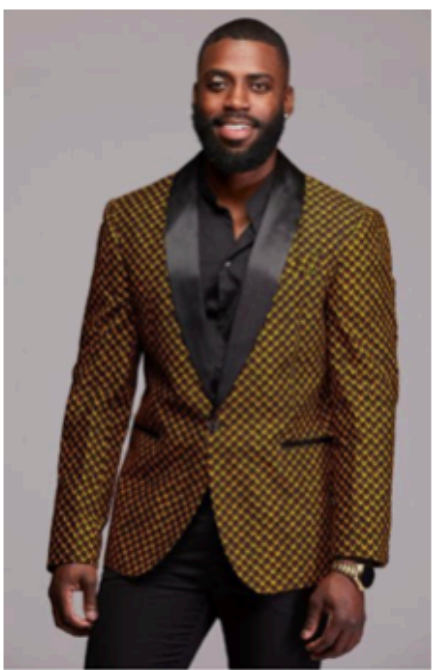

Research Image 6 


\section{Cloud Nine} Betty

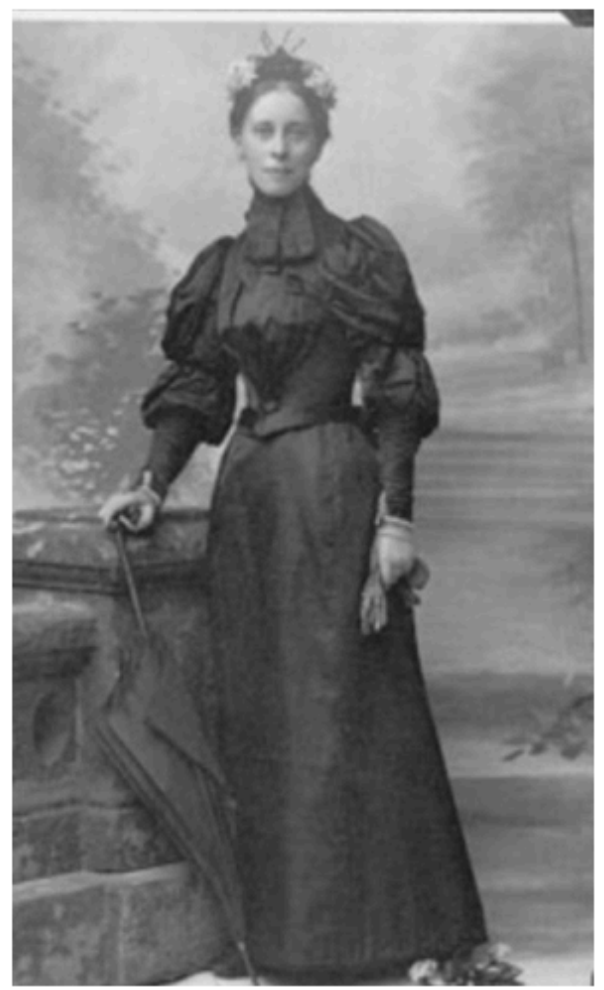

Research Image 7

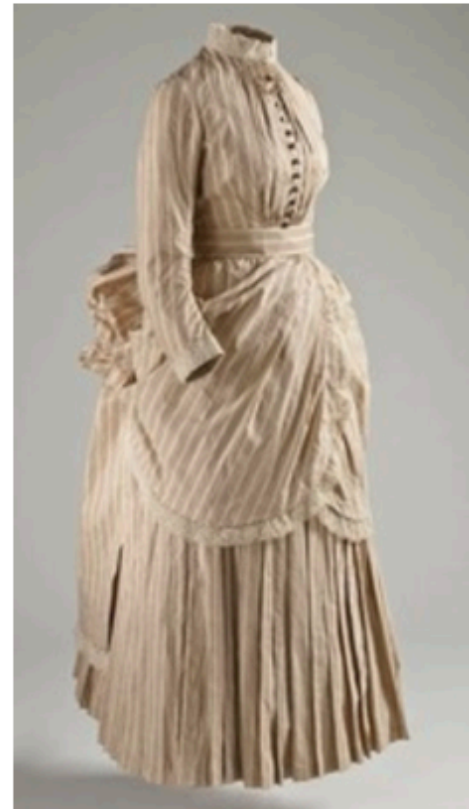

Research Image 10

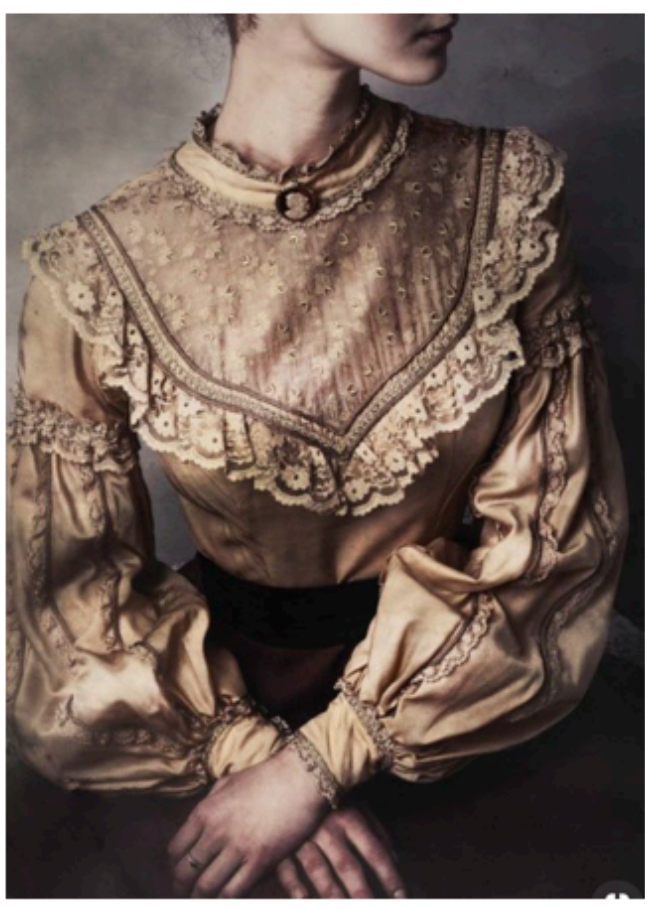

Research Image 8

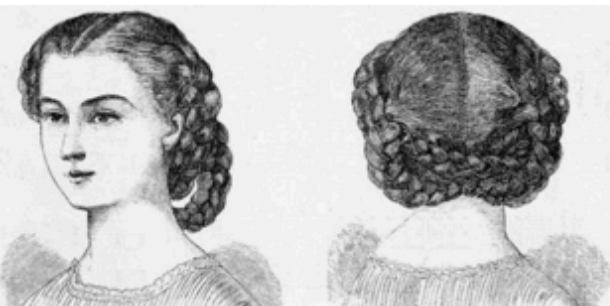

Research Image 9

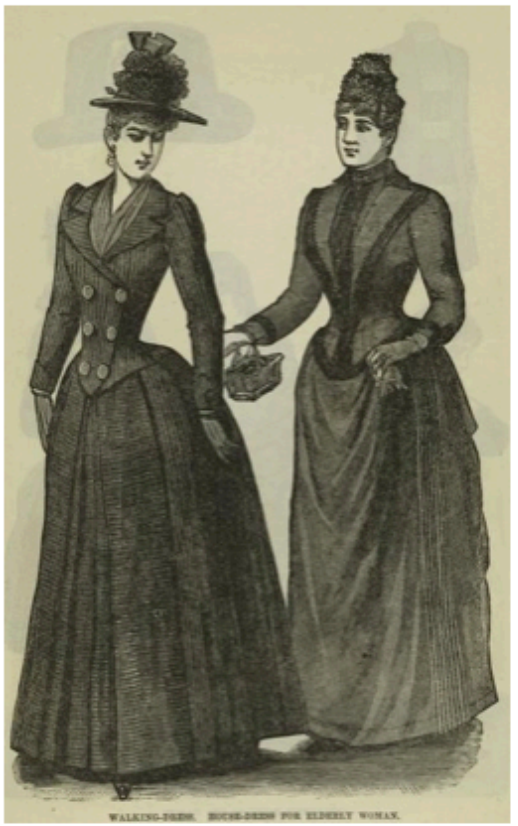

Research Image 11 


\section{Cloud Nine} Joshua

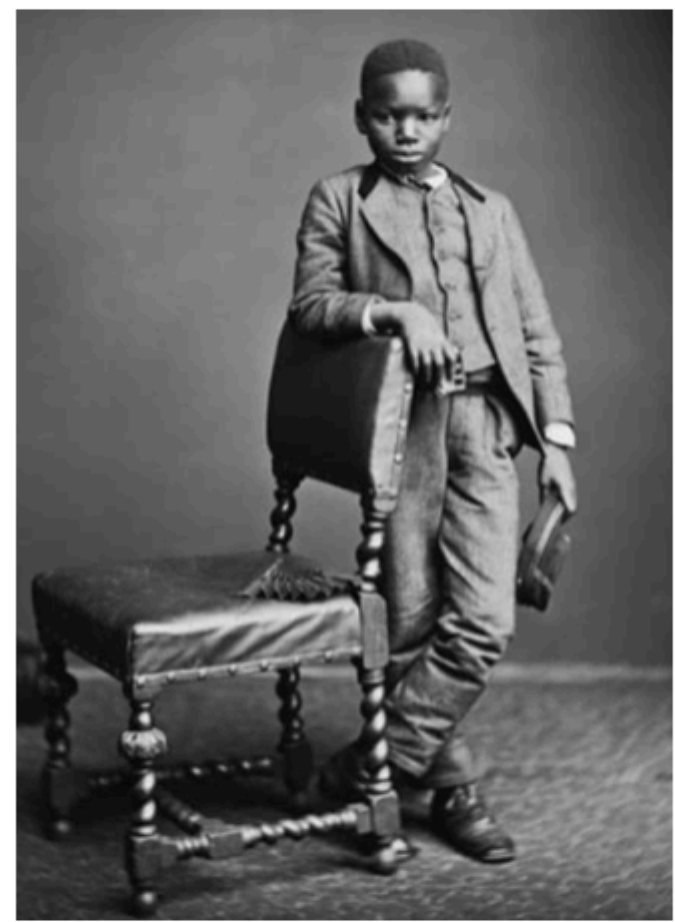

Research Image 12

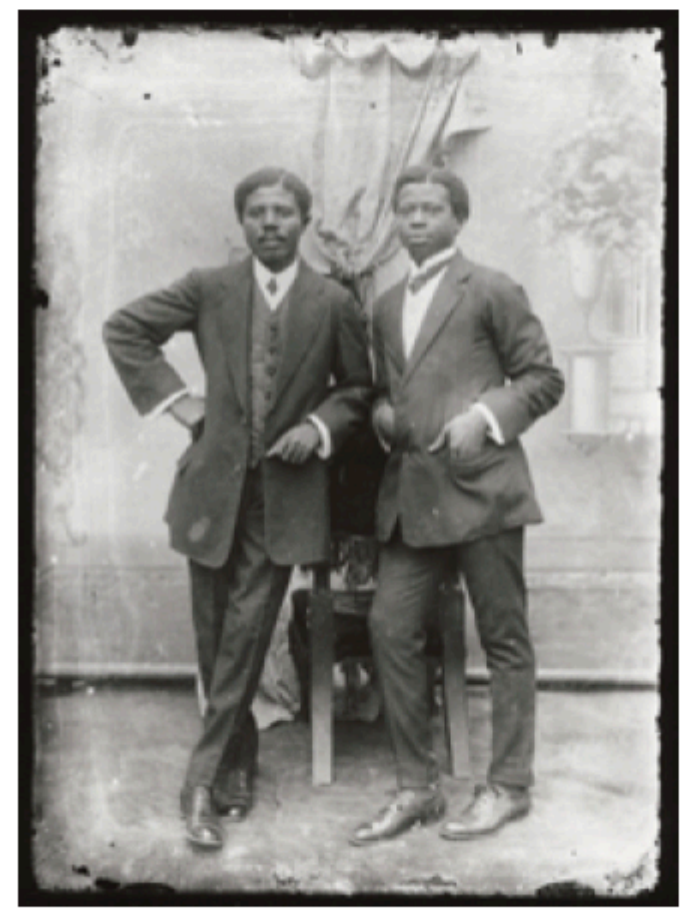

Research Image 14

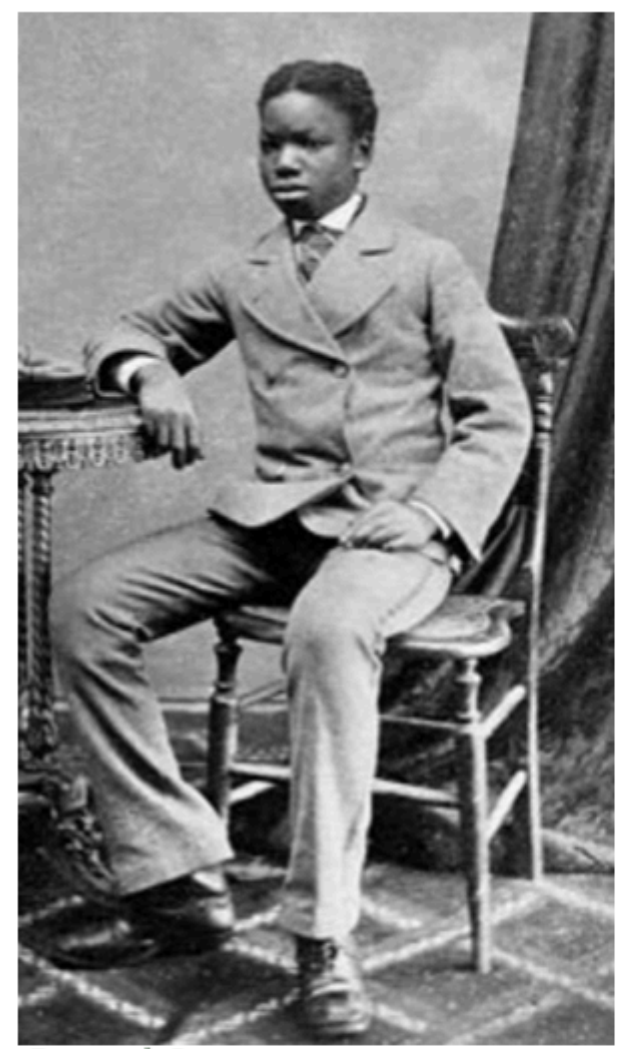

Research Image 13

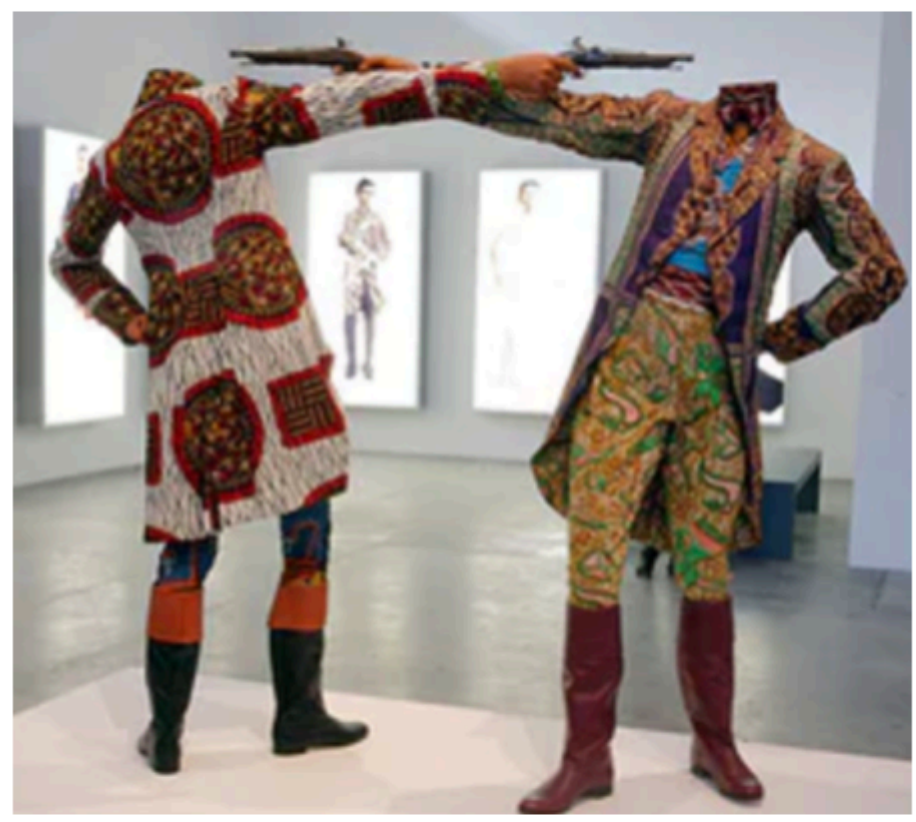

Research Image 15

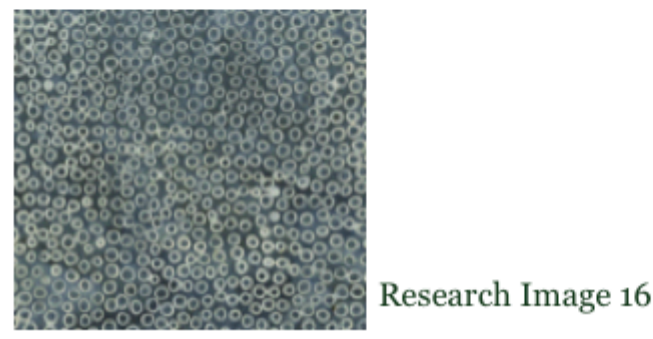




\section{Cloud Nine}

Joshua

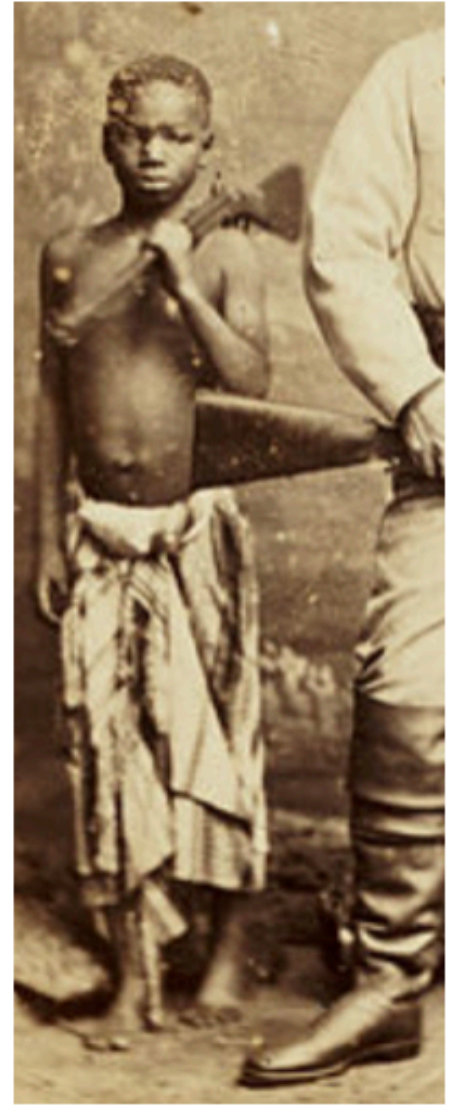

Research Image 17

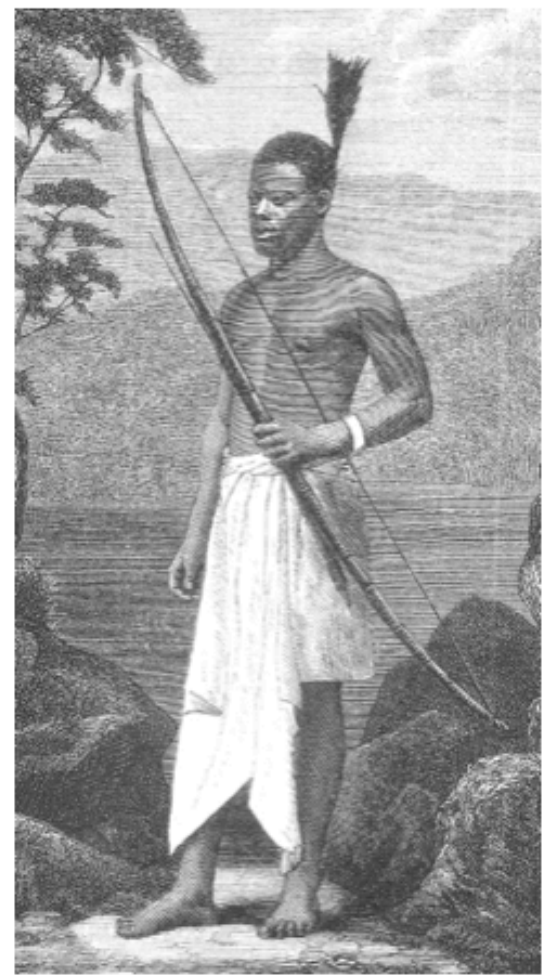

Research Image 19

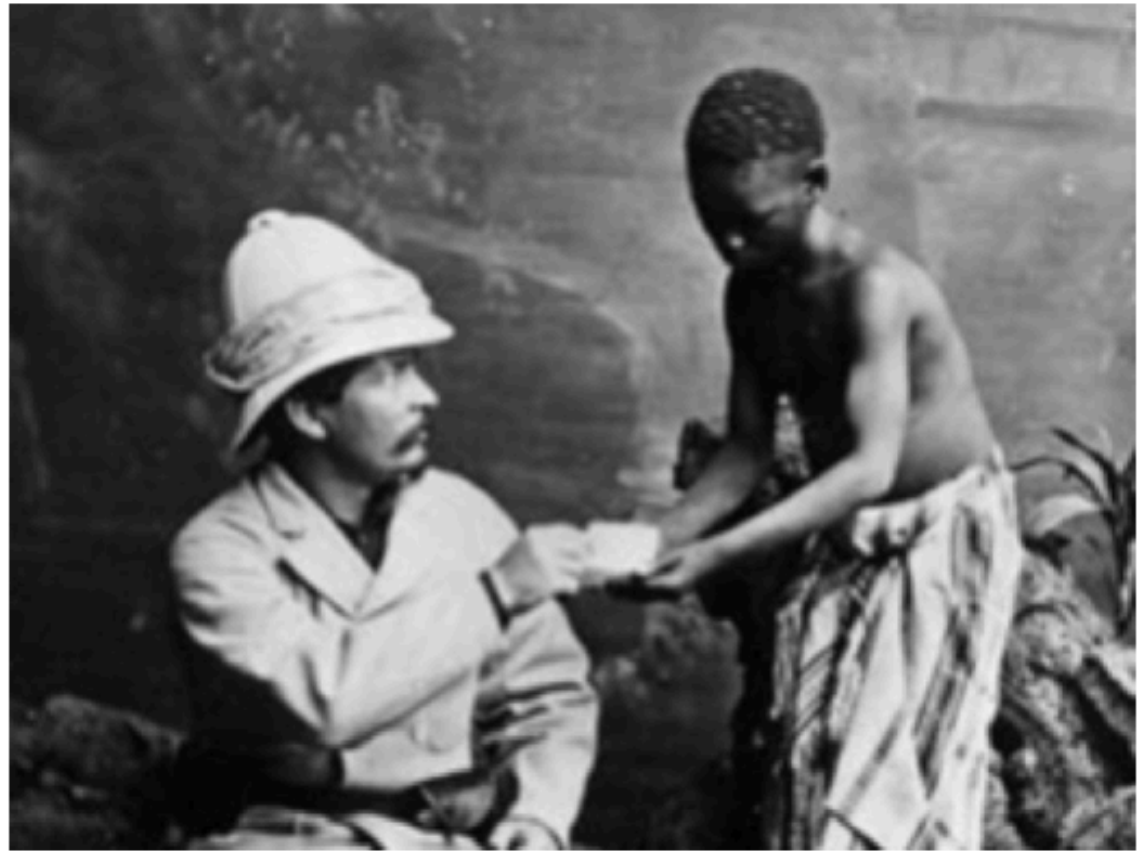

Research Image 18

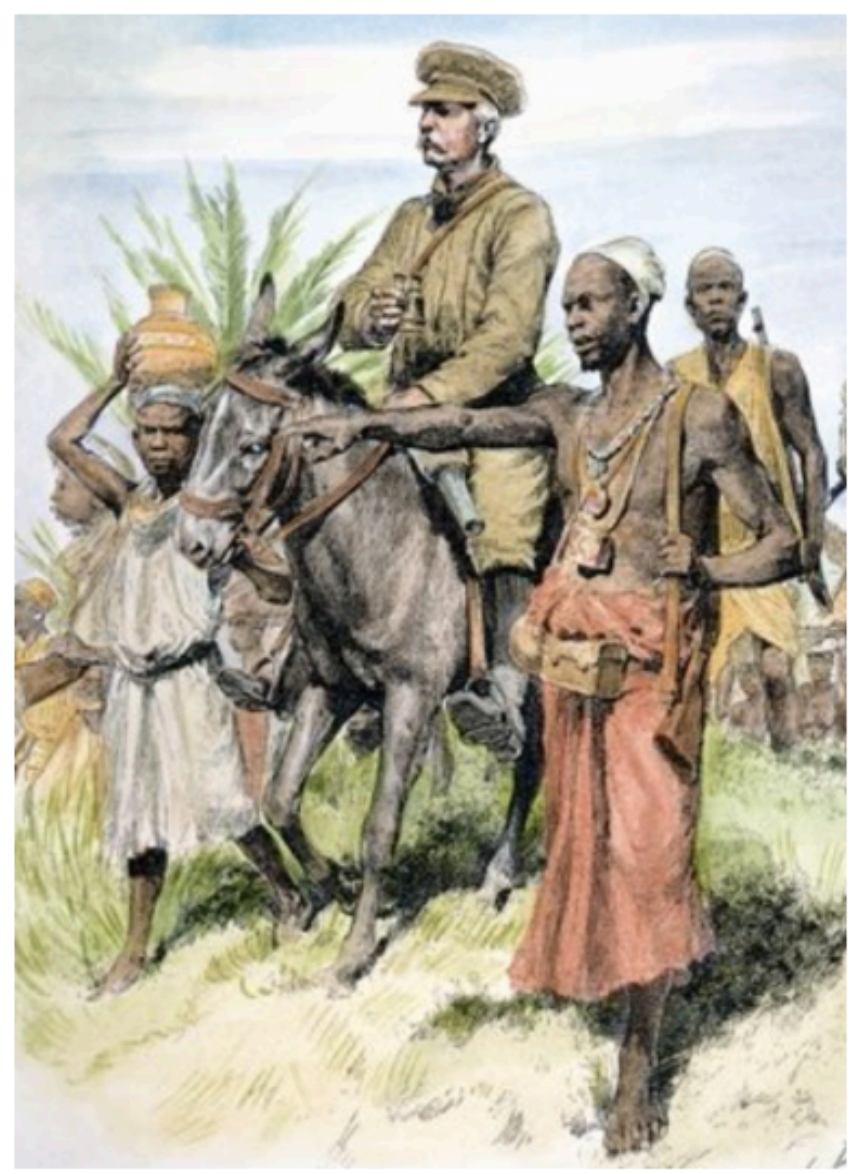

Research Image 20 


\section{Cloud Nine}

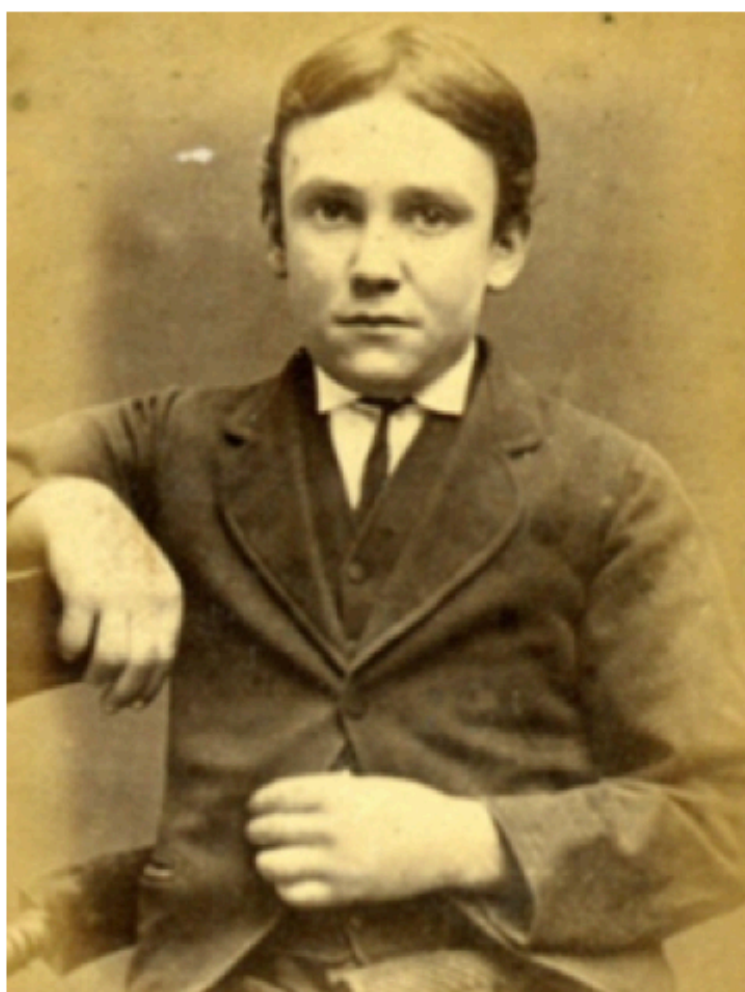

Research Image 21

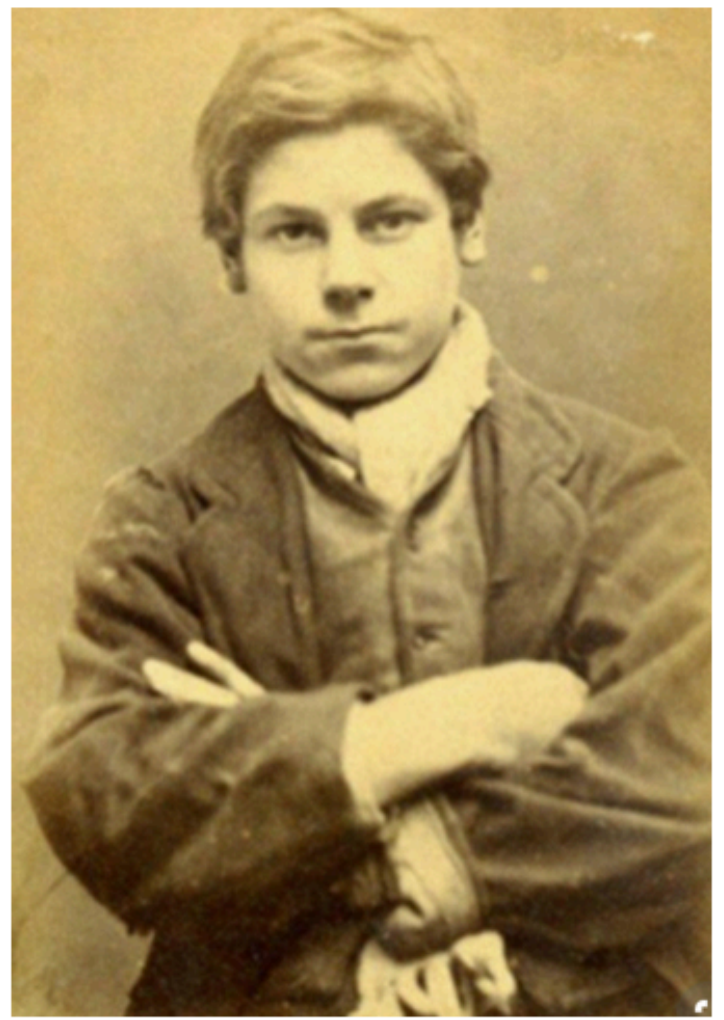

Research Image 22

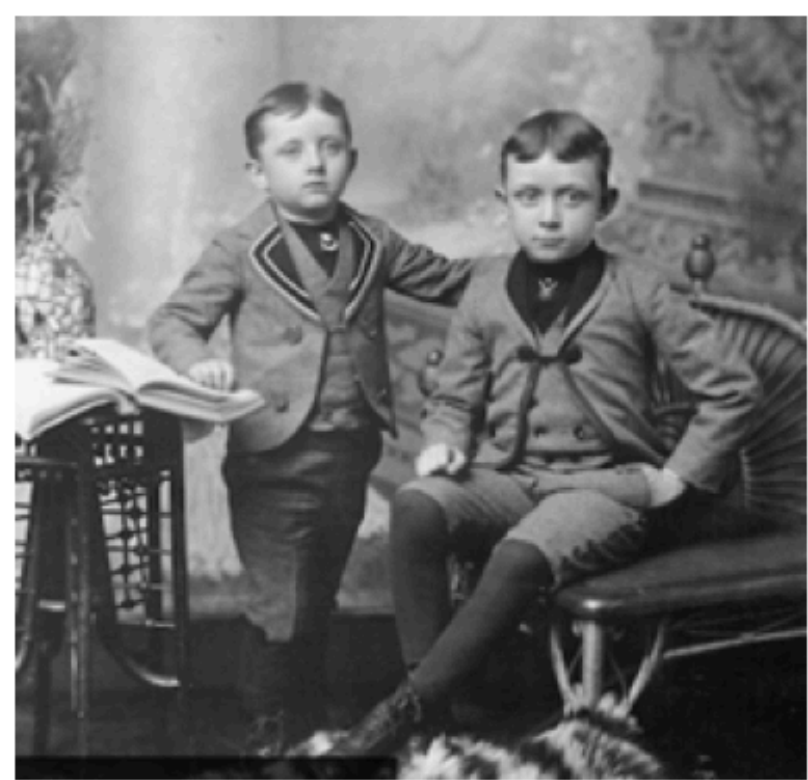

Research Image 23

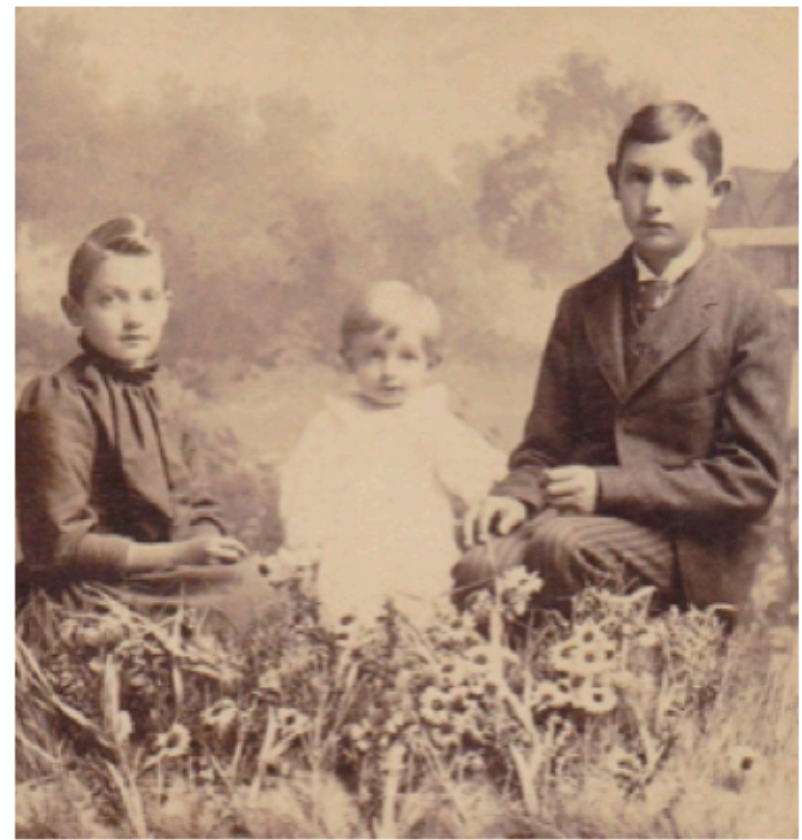

Research Image 24

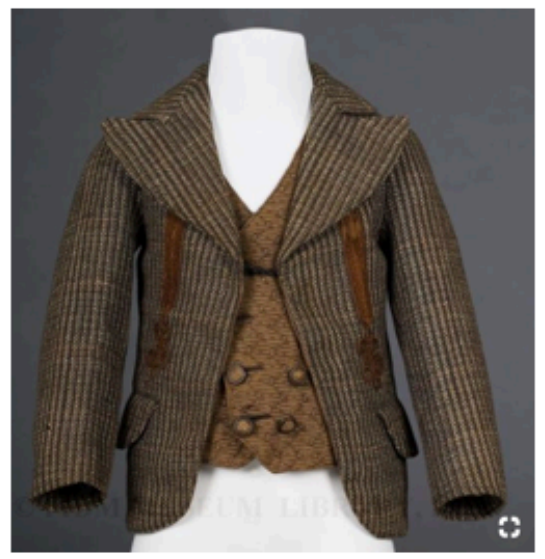

Research Image 25 


\section{Cloud Nine}

Victoria

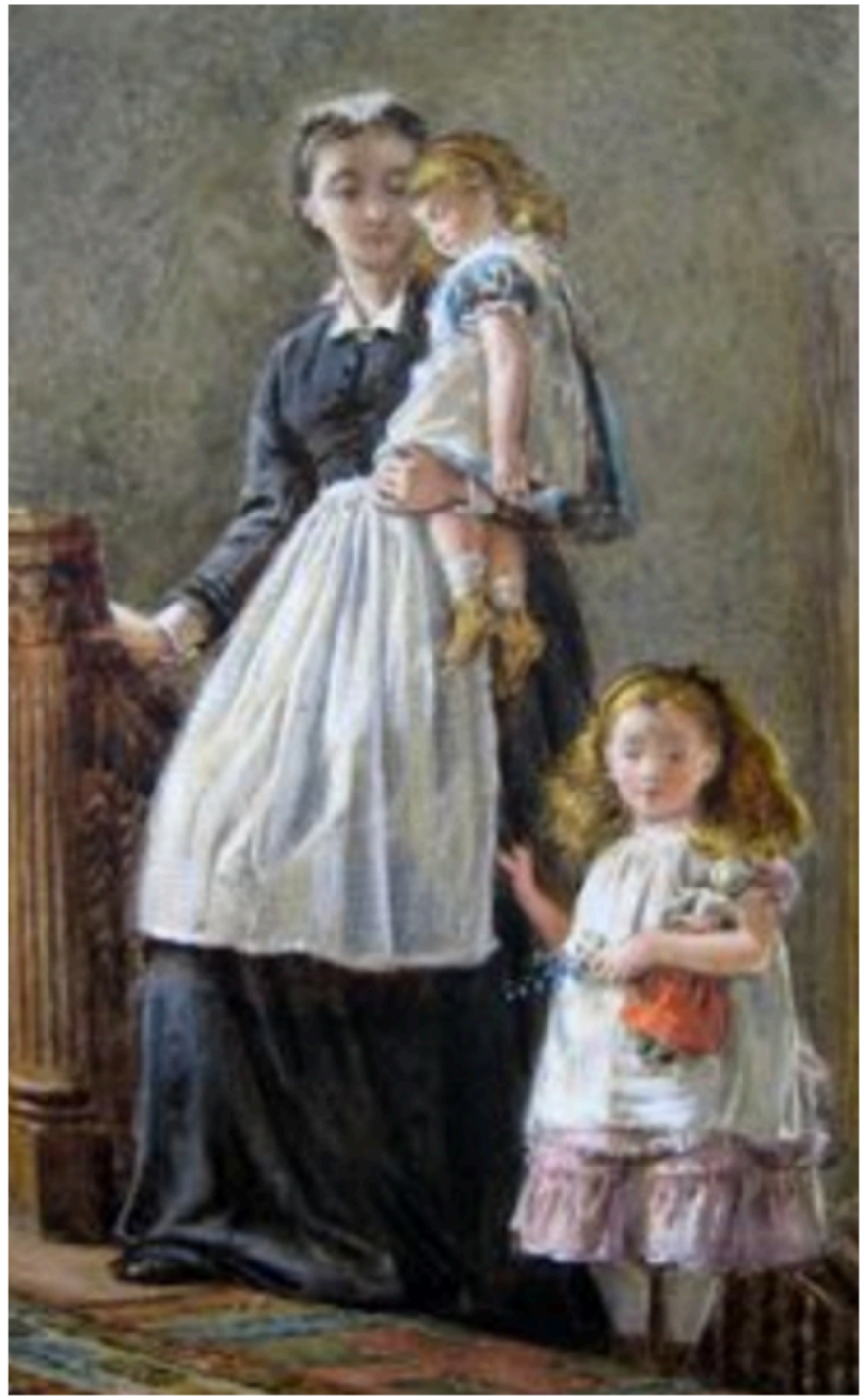

Research Image 26

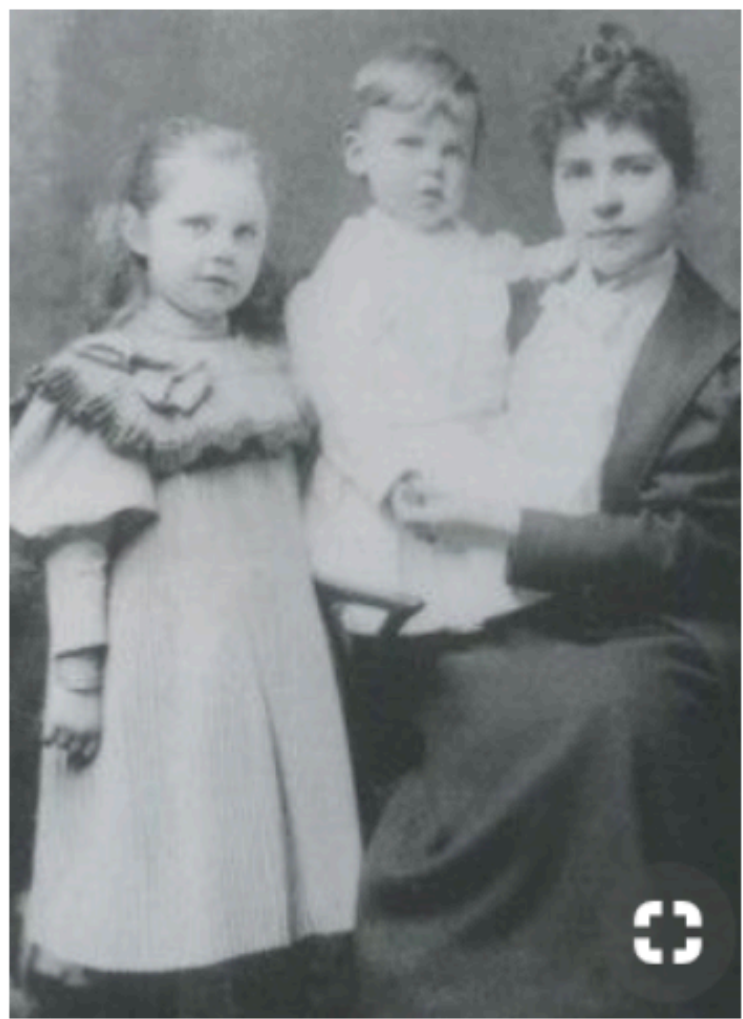

Research Image 27

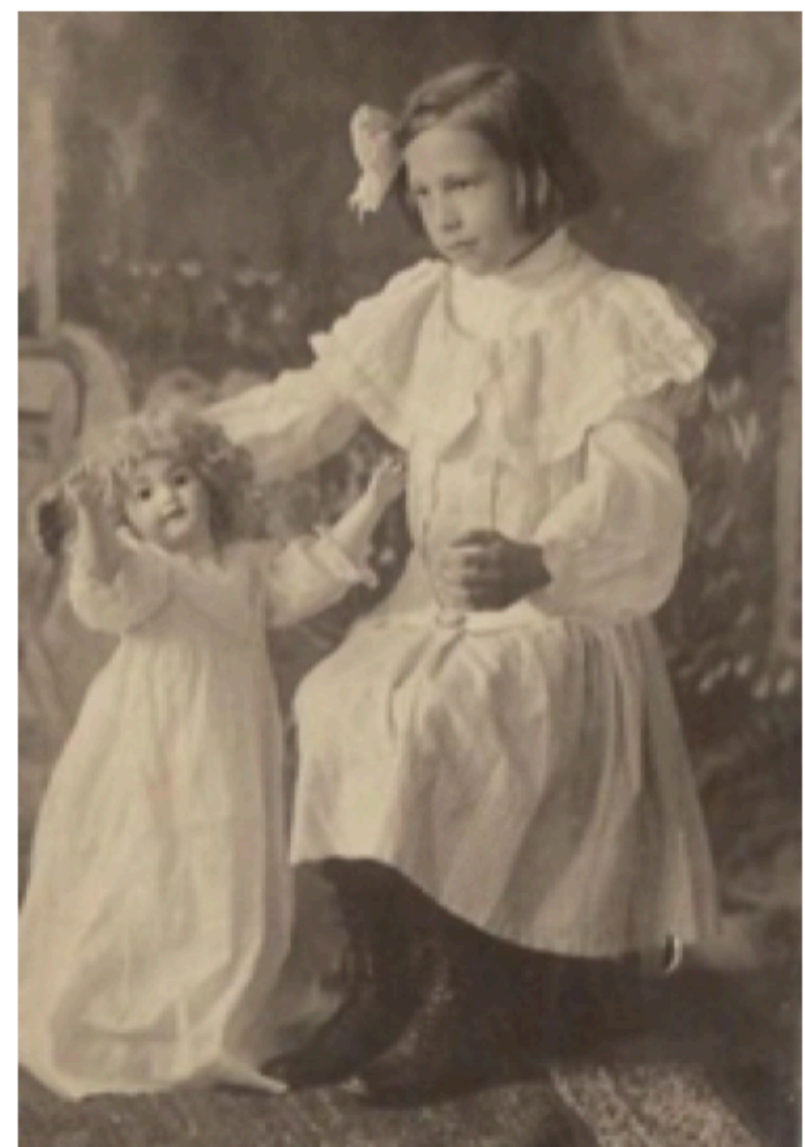

Research Image 28 


\section{Cloud Nine}

Maud

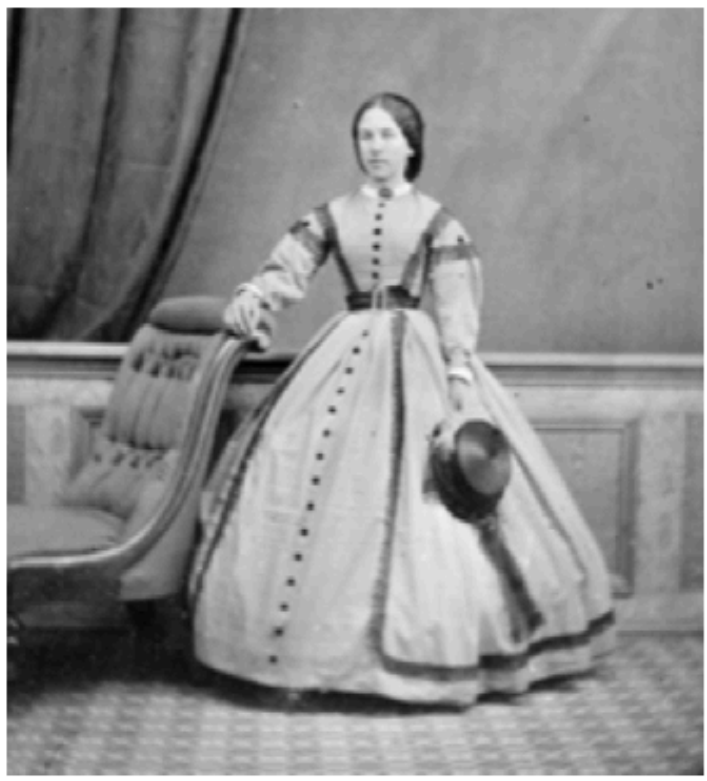

Research Image 29

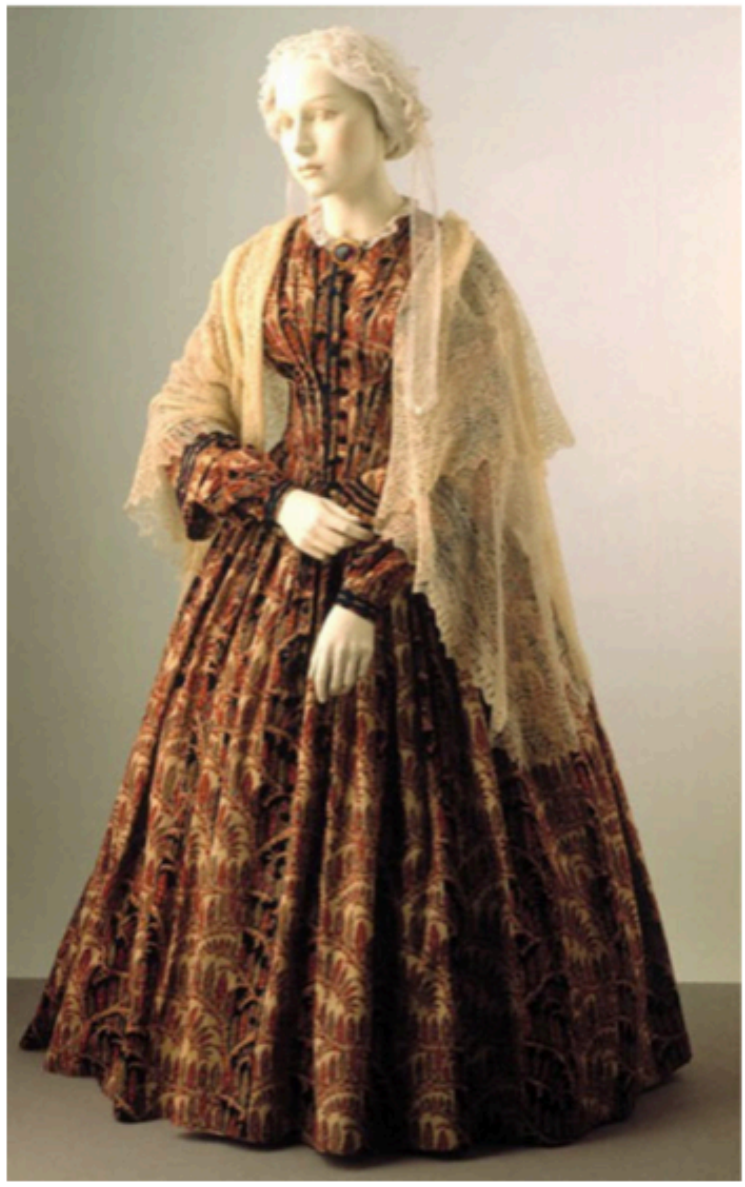

Research Image 31

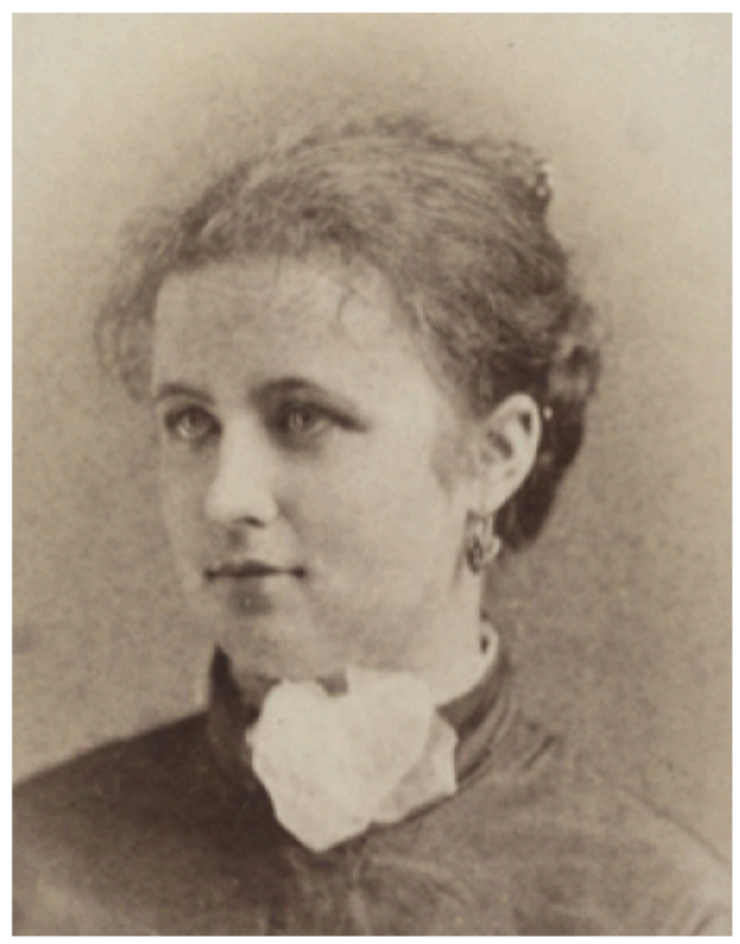

Research Image 30

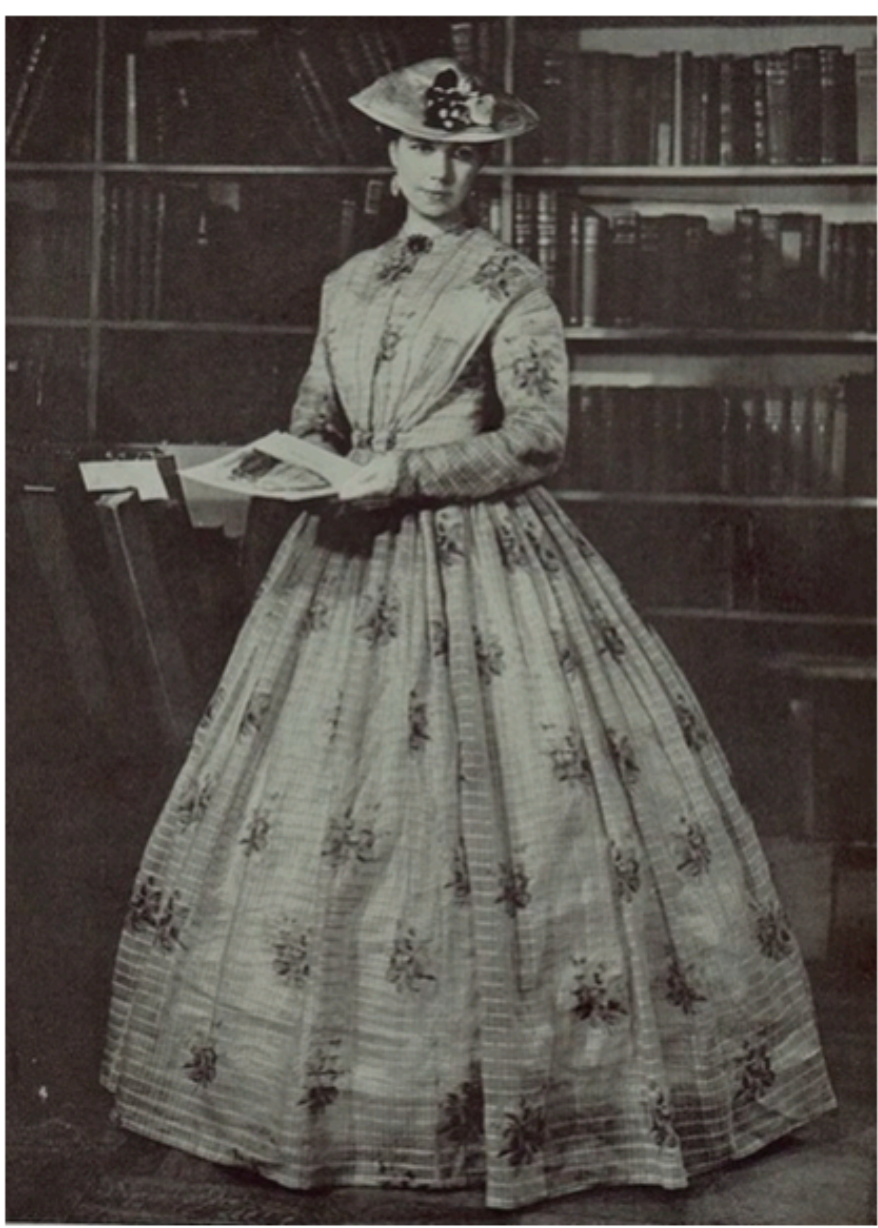

Research Image 32 


\section{Cloud Nine}

Ellen

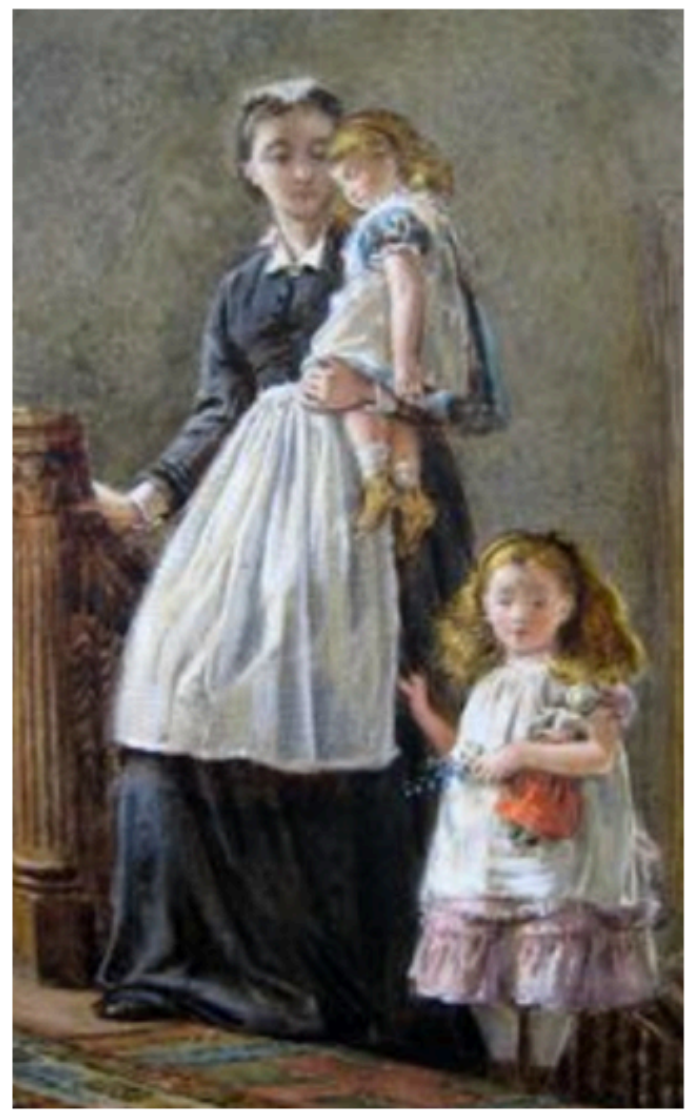

Research Image 33

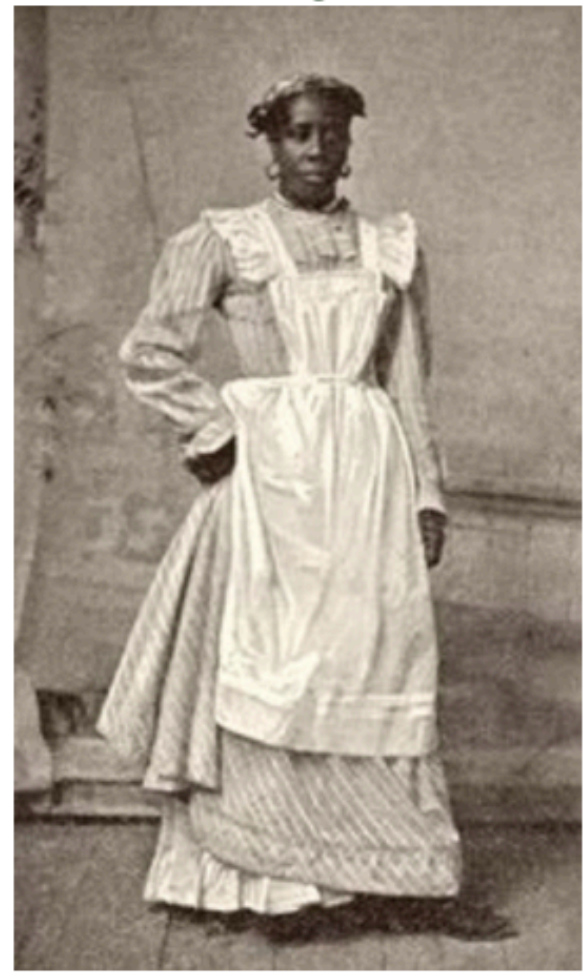

Research Image 35

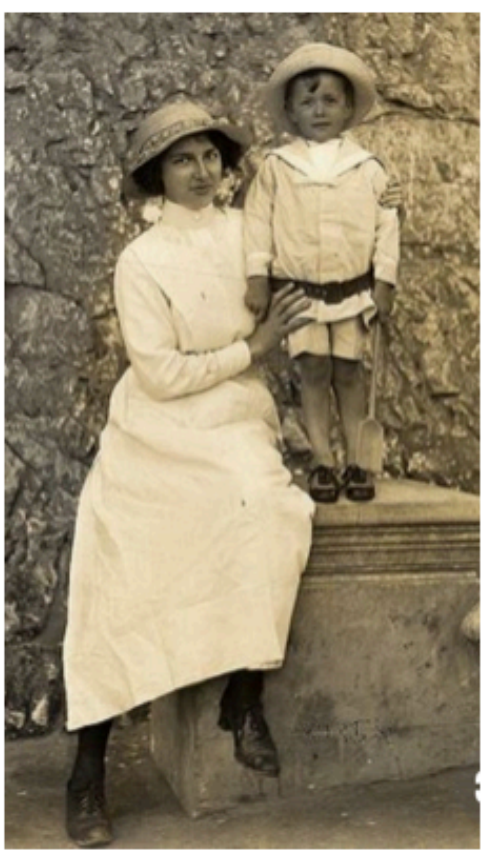

Research Image 36 


\section{Cloud Nine}

Harry Bagley

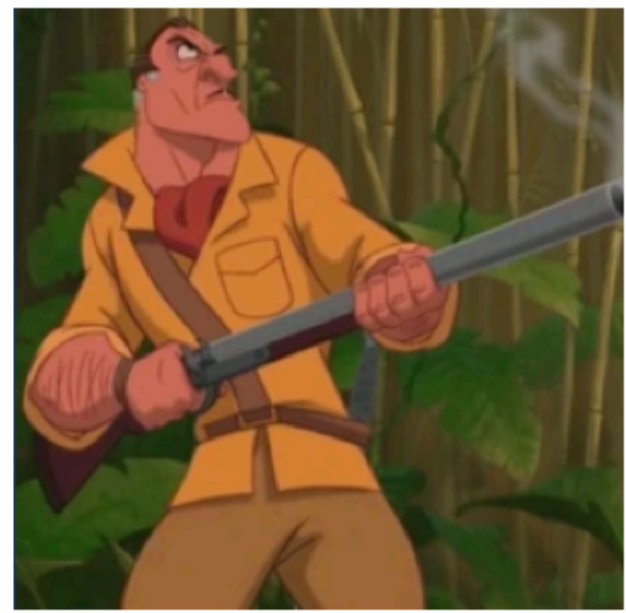

Research Image 37

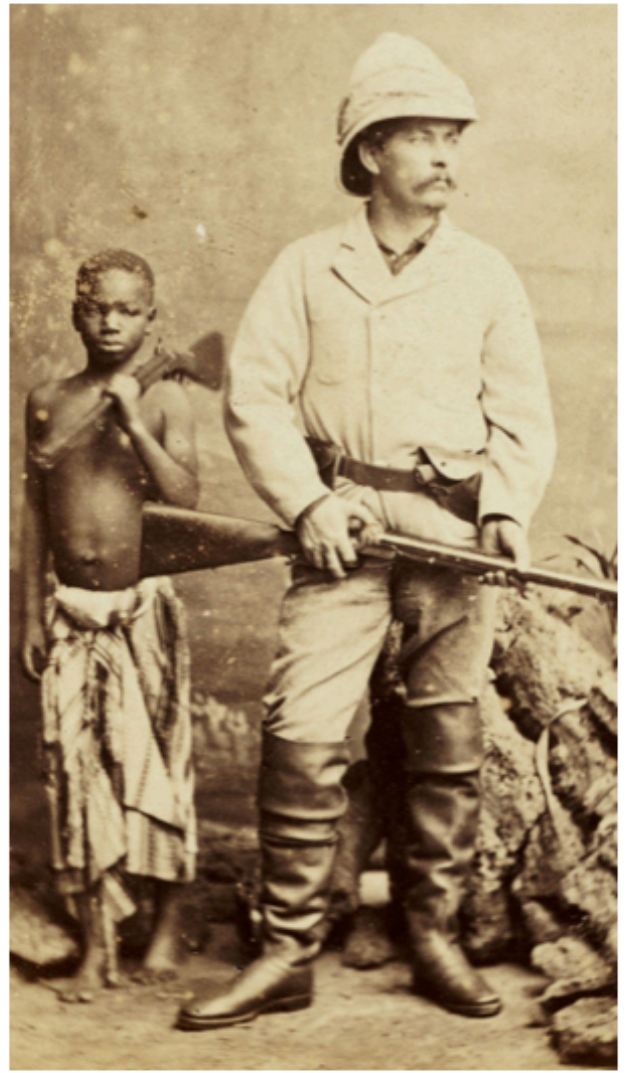

Research Image 39

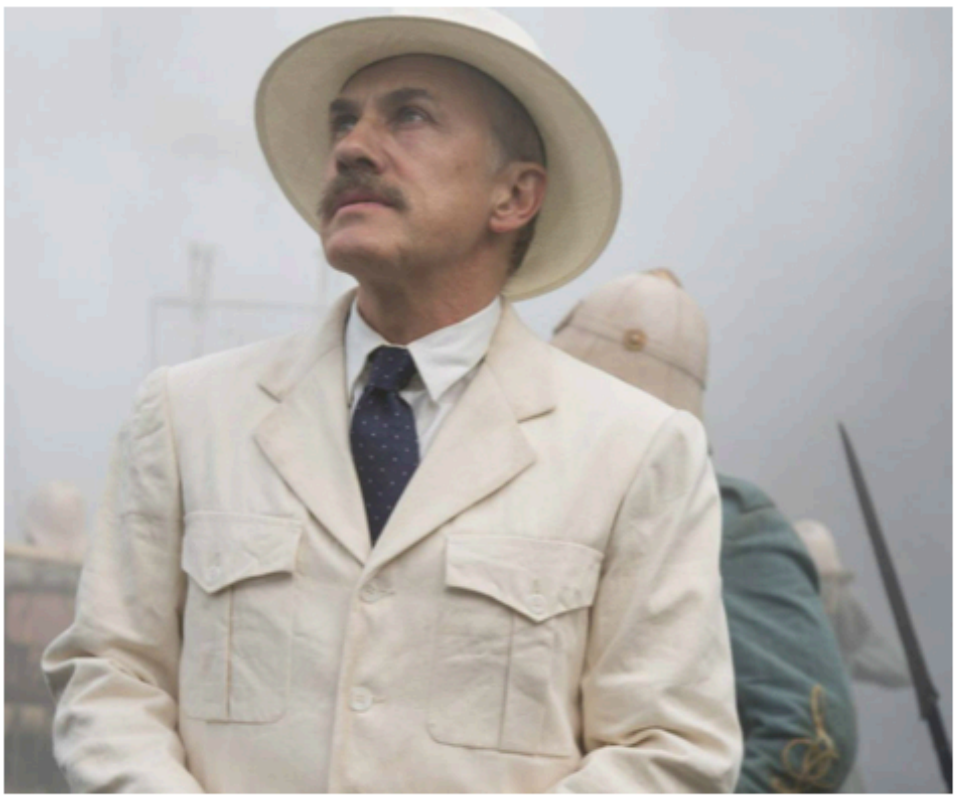

Research Image 38

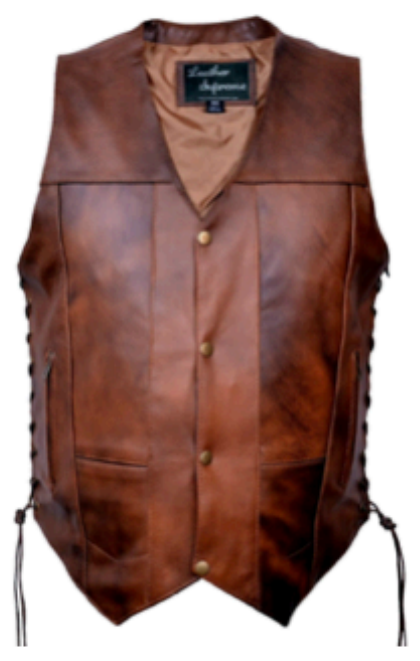

Research Image 40

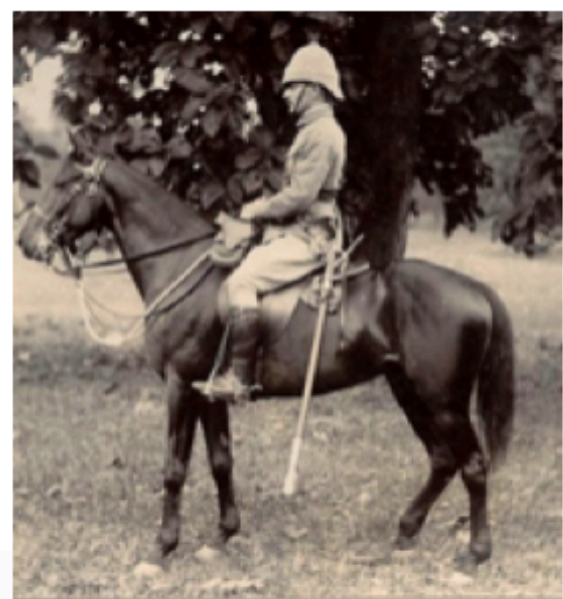

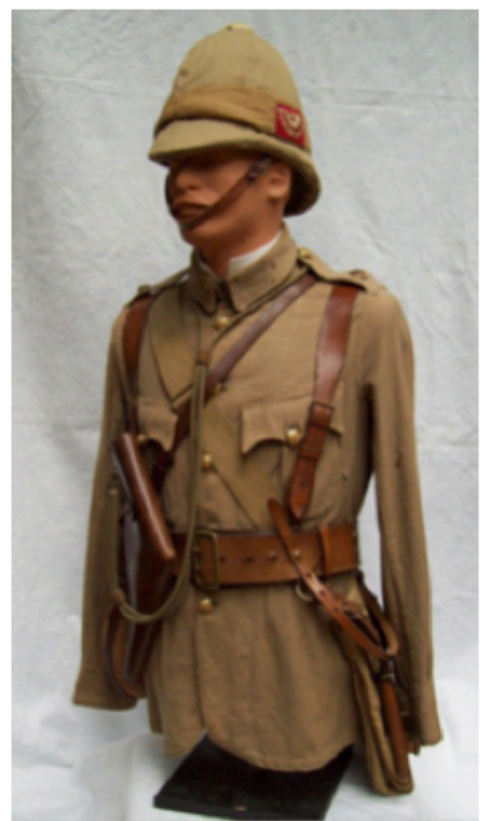

Research Image 41 


\section{Cloud Nine}

Mrs. Caroline Saunders
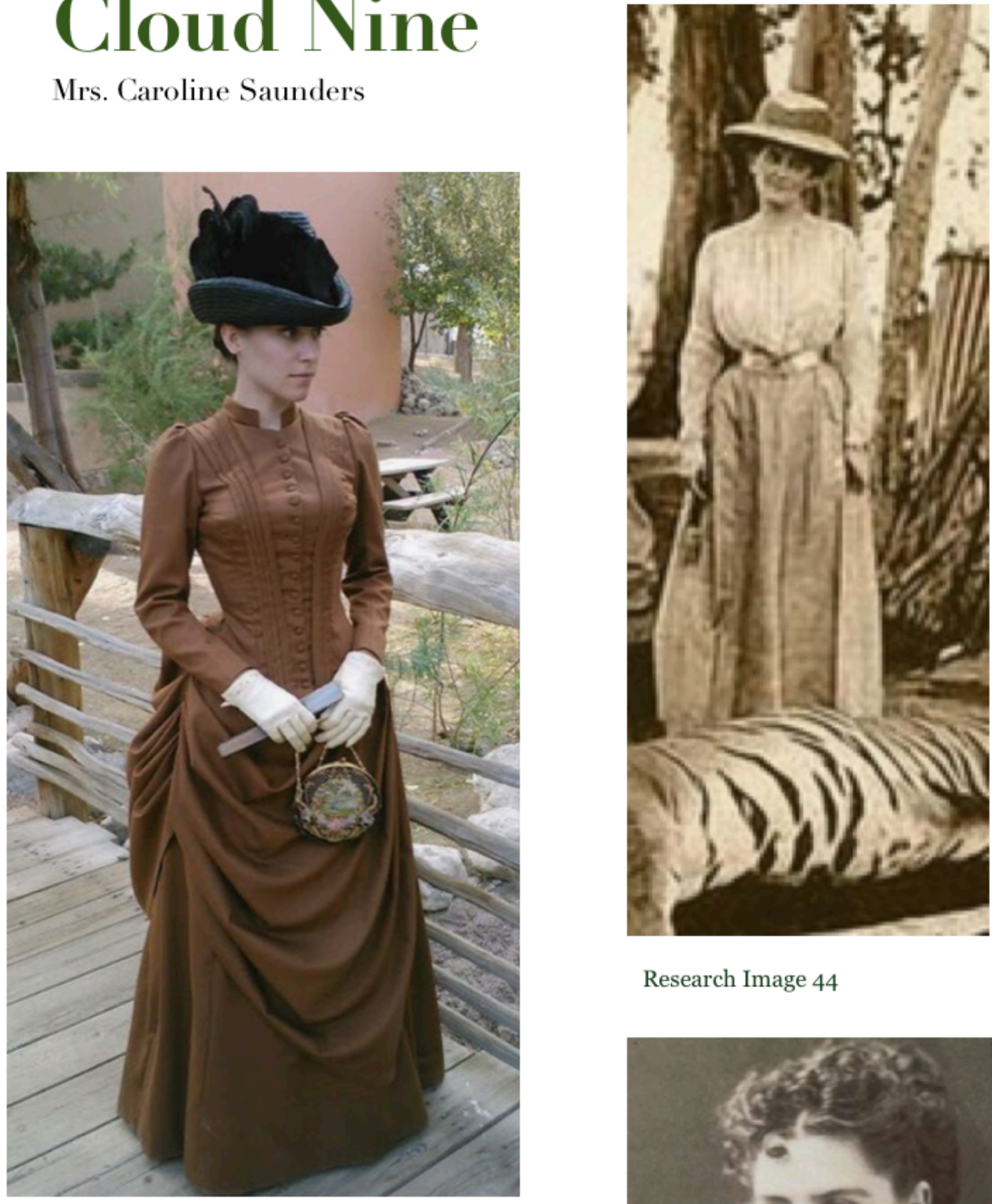

Research Image 44

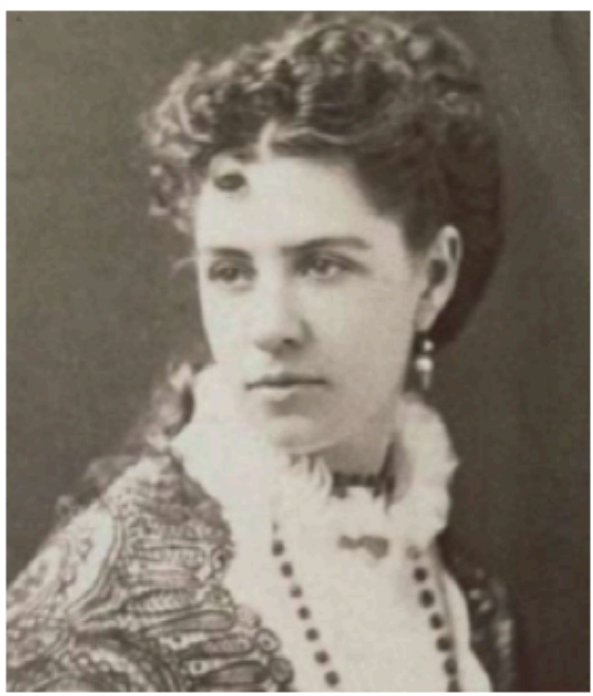

Research Image 45 


\section{Cloud Nine}

Betty

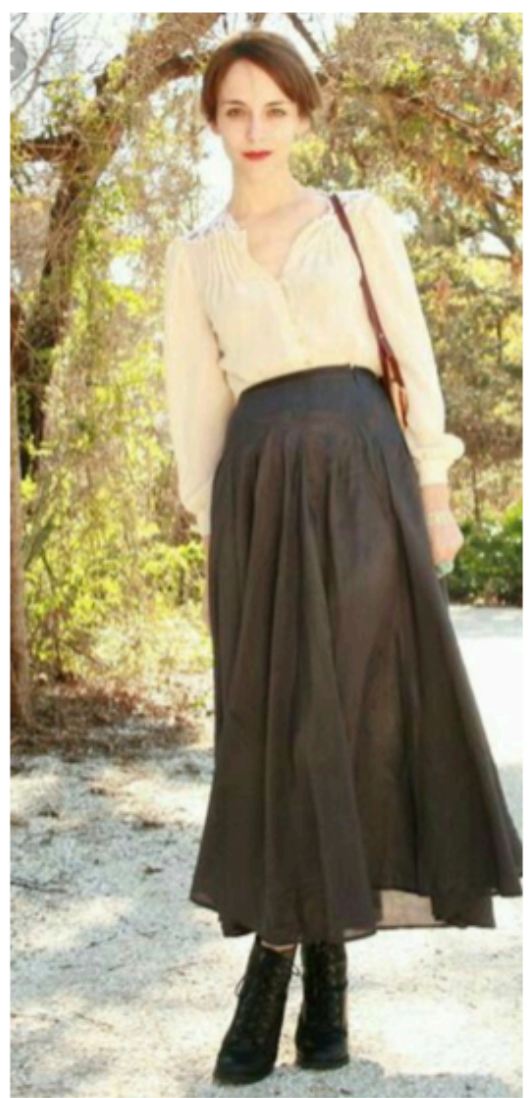

Research Image 46

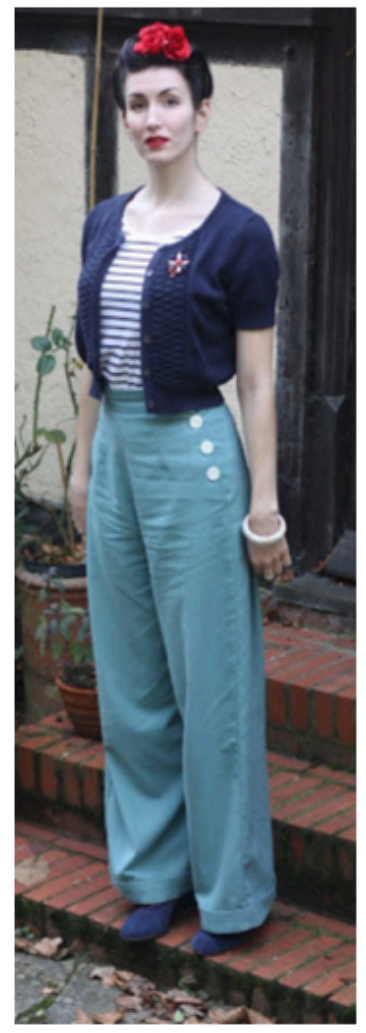

Research Image 48

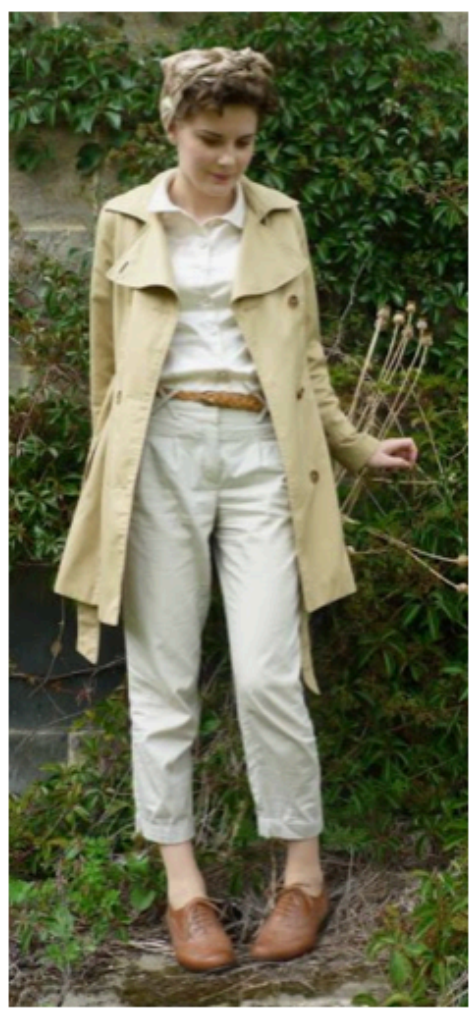

Research Image 47

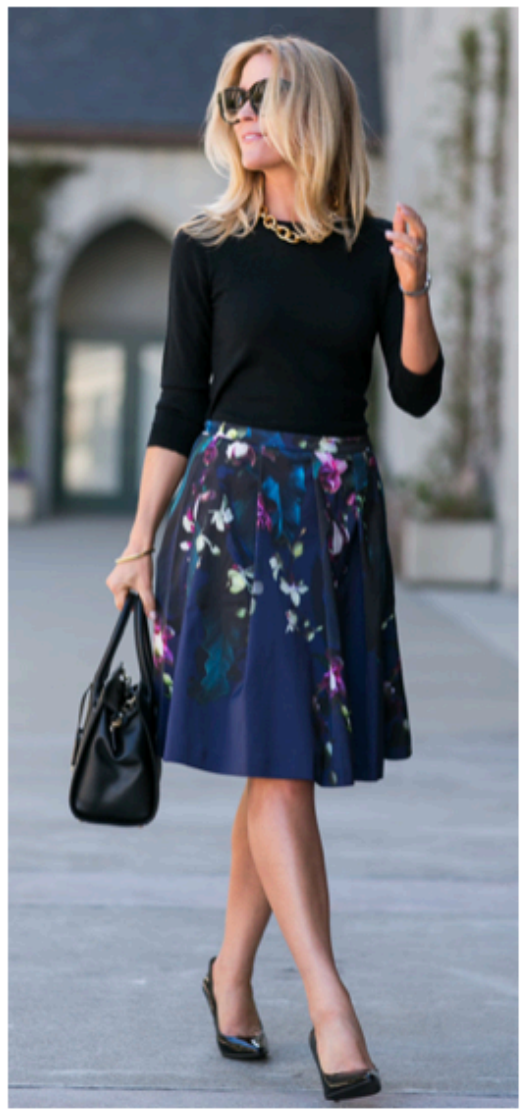

Research Image 49 


\section{CLOUD $\mathbb{N} \| \mathbb{N}$ E}

\section{BETाY}

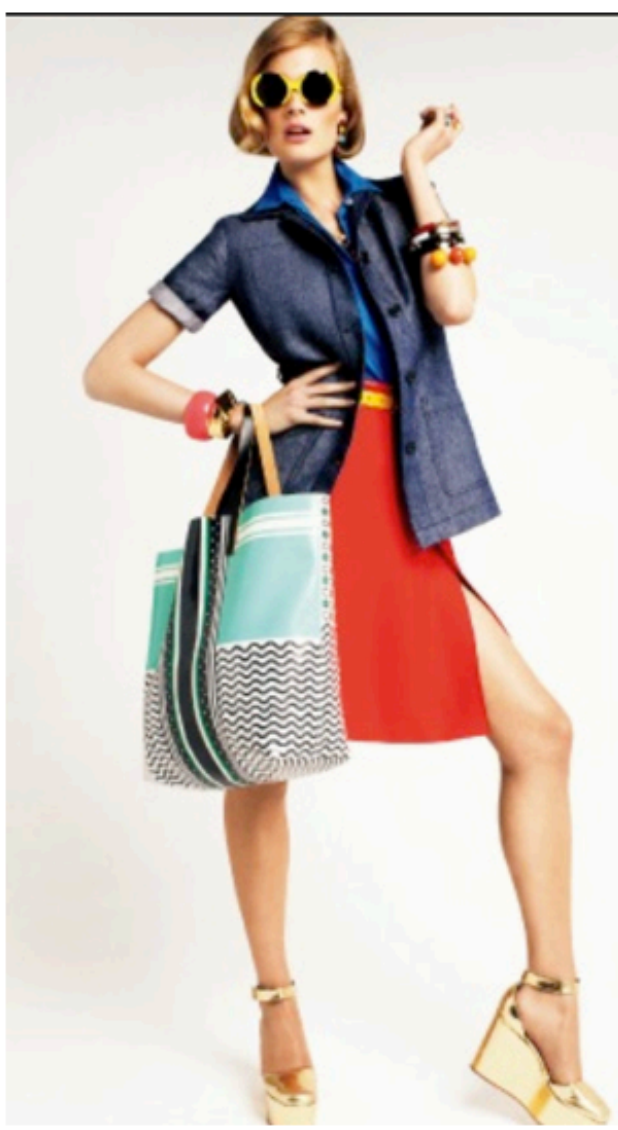

Research Image 50
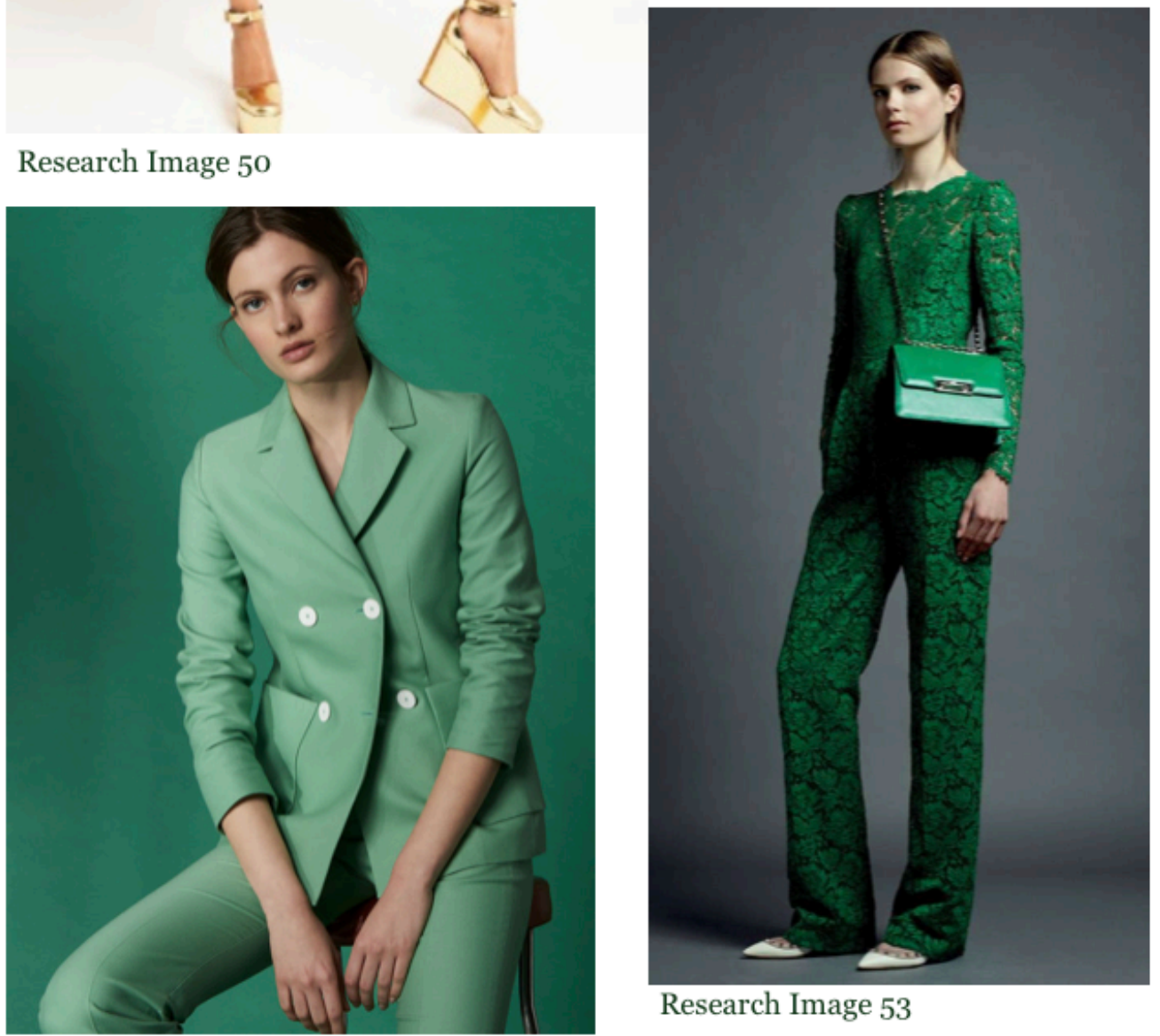

Research Image 53

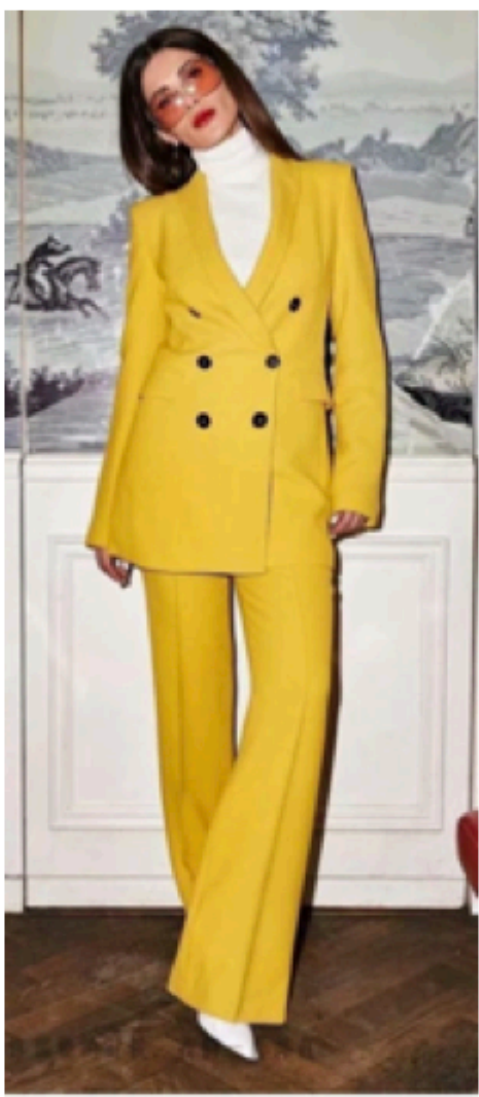

Research Image 54

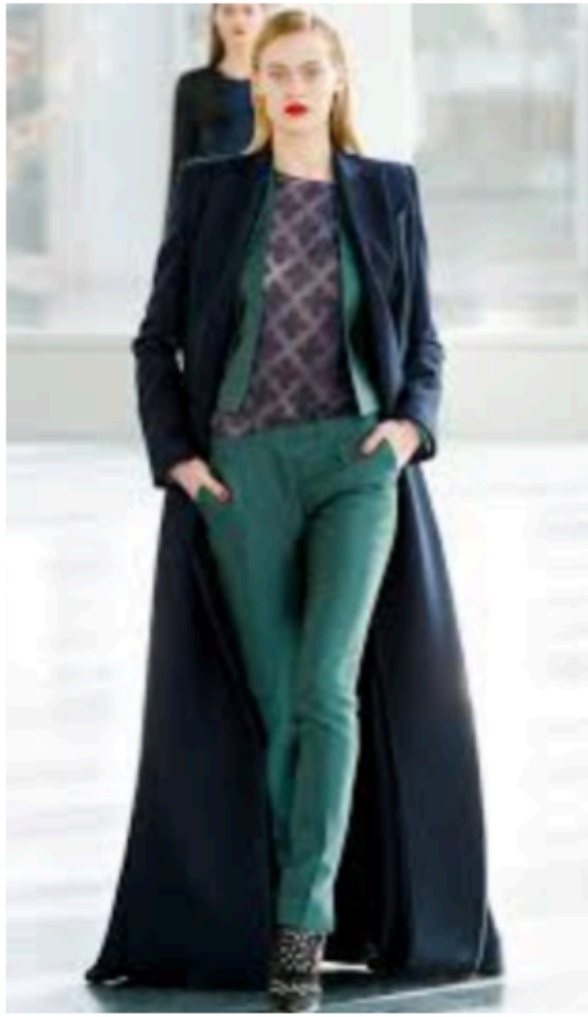

Research Image 51 


\section{Cloud Nine}

Edward

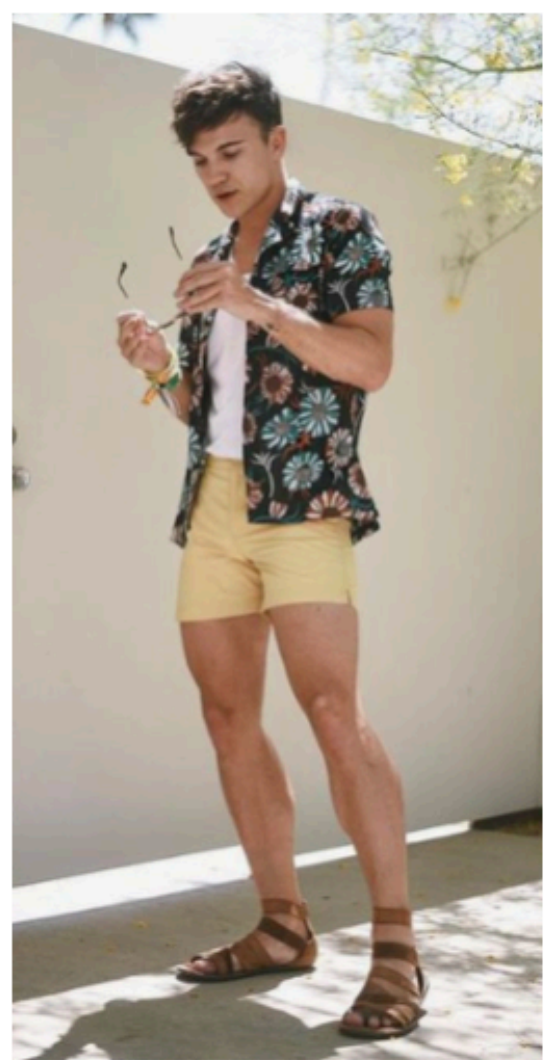

Research Image 55

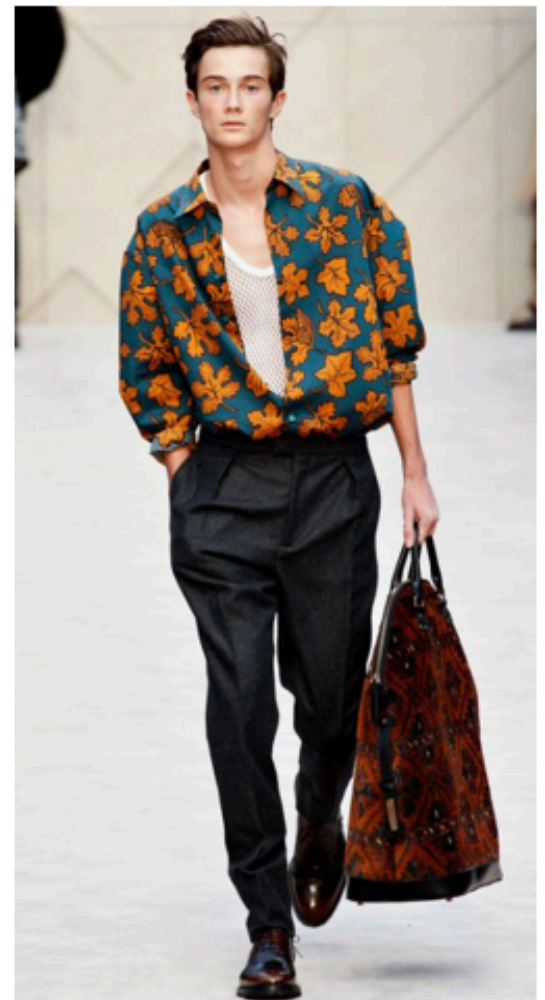

Research Image 56

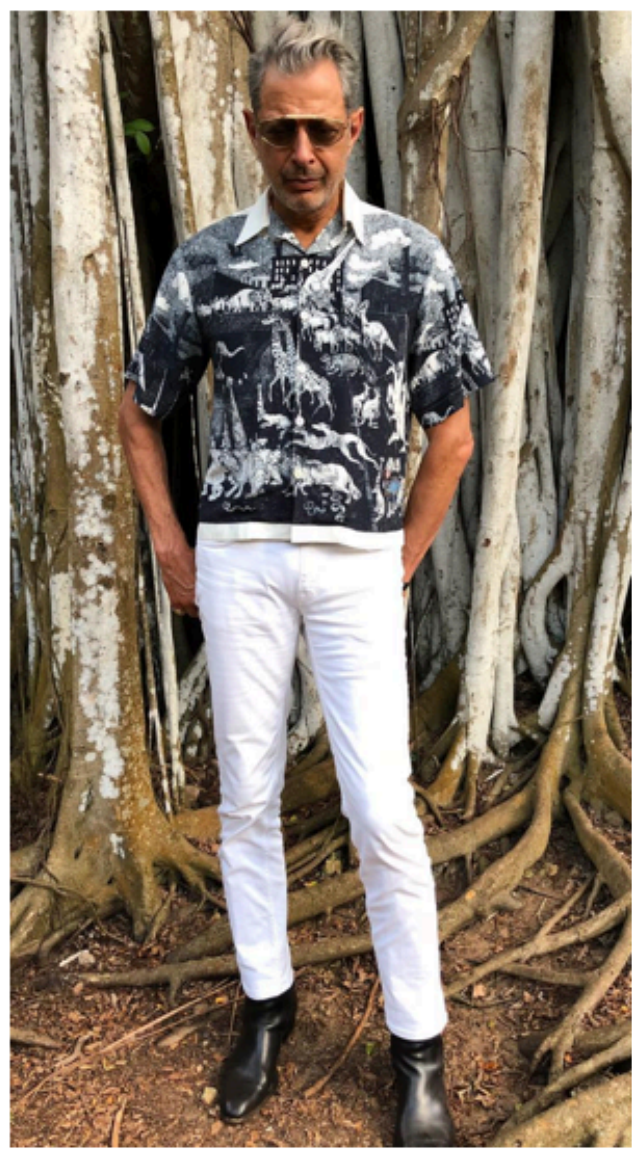

Research Image 57

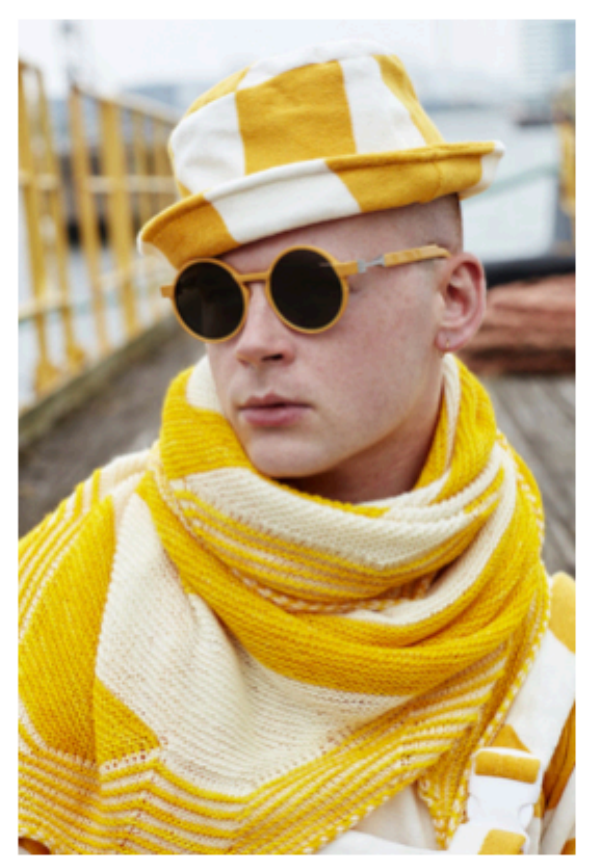

Research Image 58

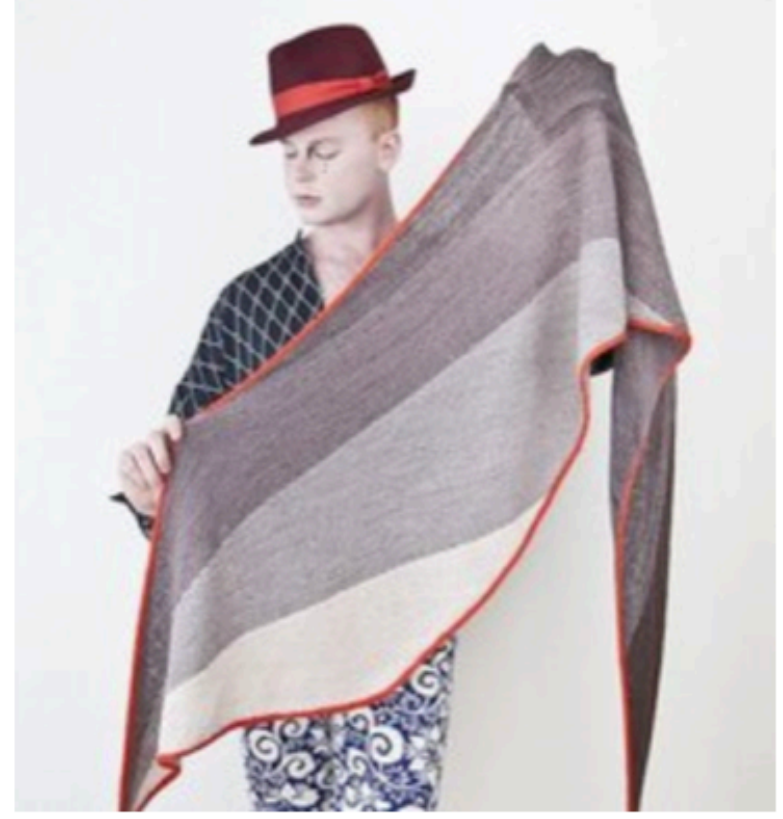

Research Image 59 


\section{CLOUD $\mathbb{N} I \mathbb{N}$ E}

\section{EDWARD}

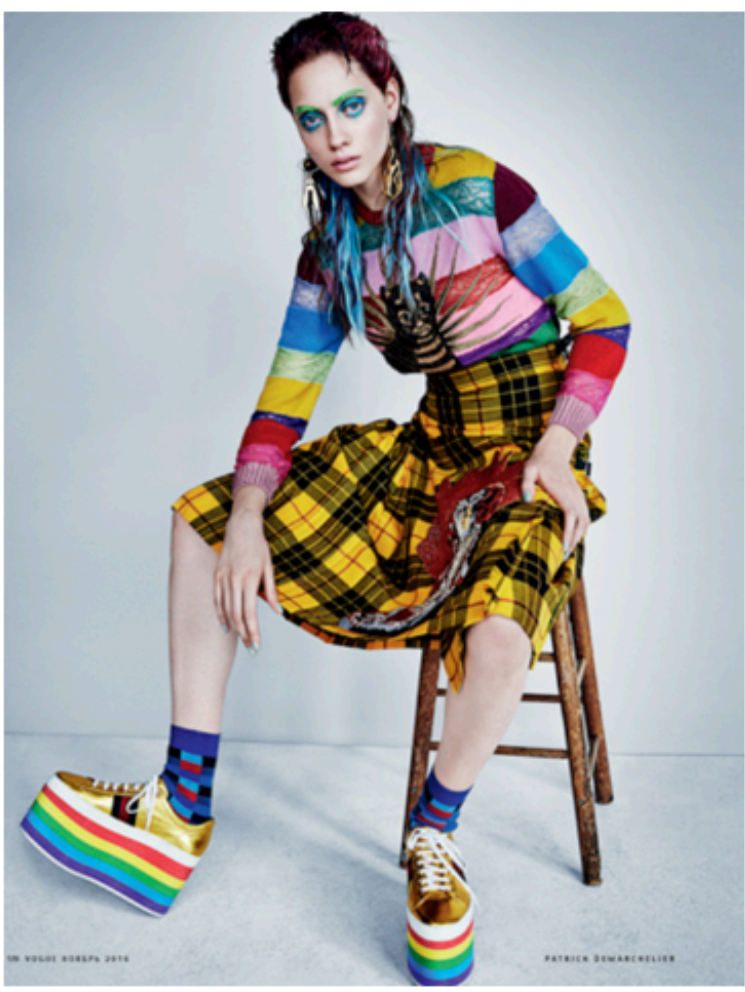

Research Image 60

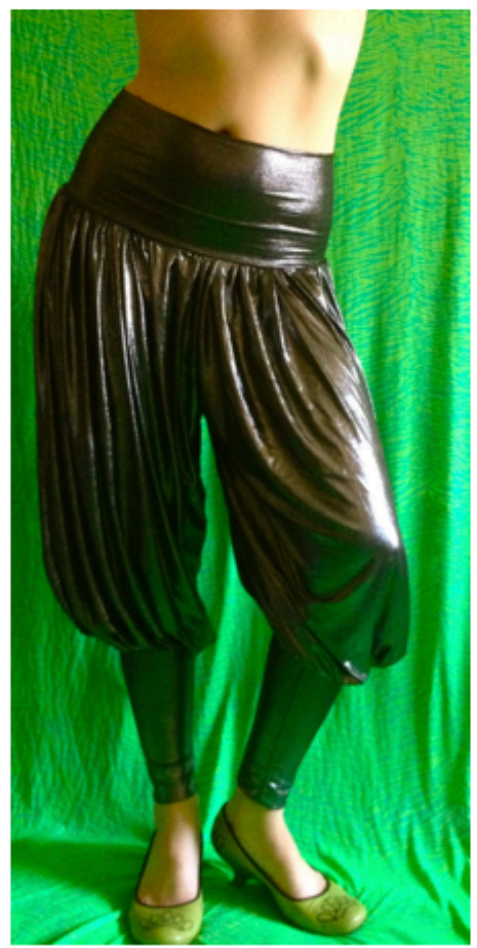

Research Image 62

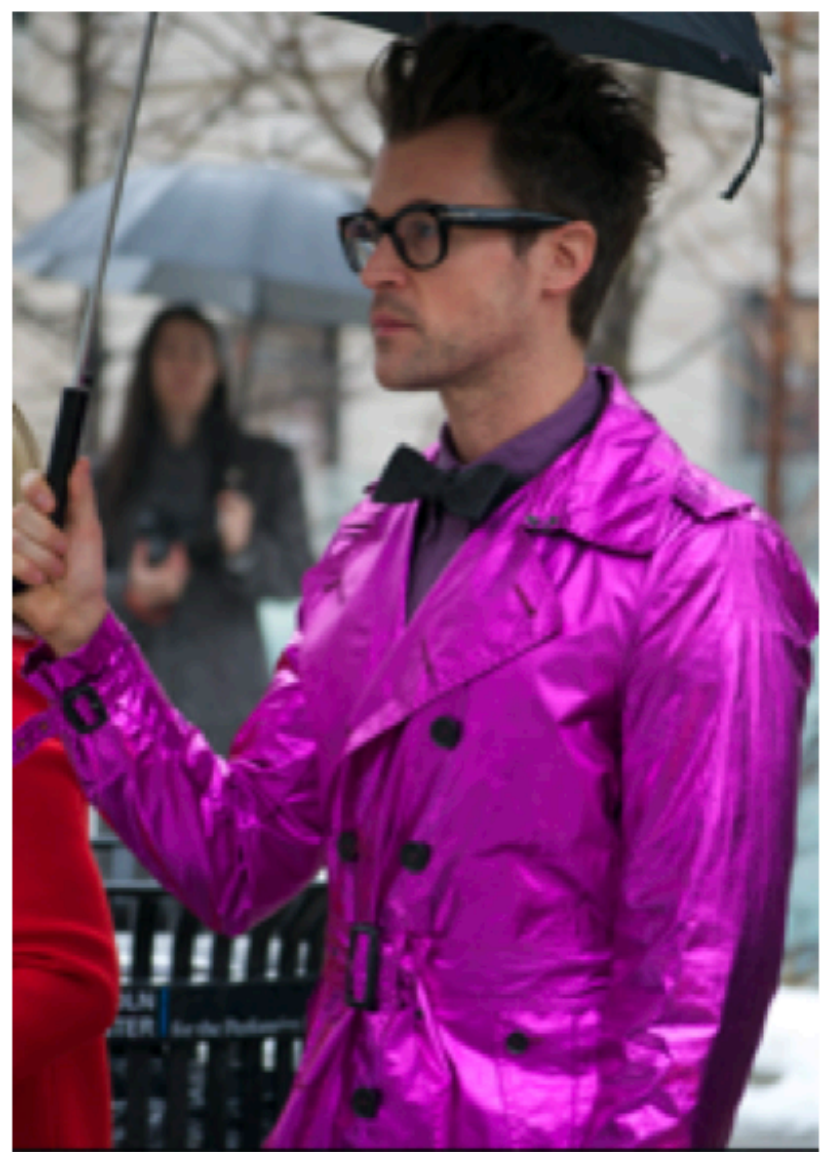

Research Image 61

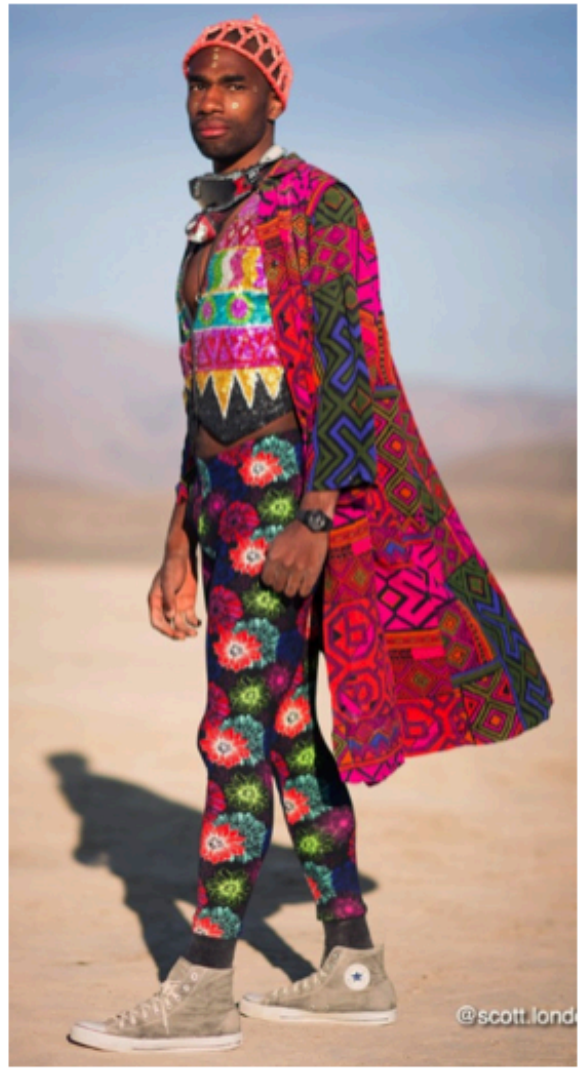

Research Image 64

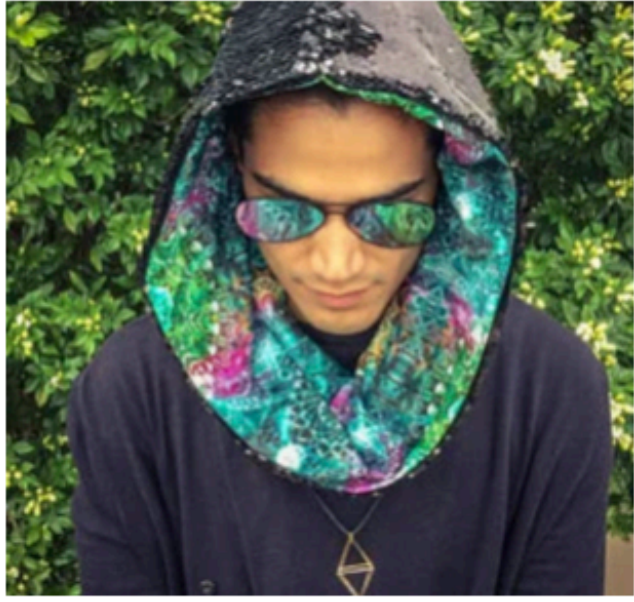

Research Image 63 


\section{Cloud Nine}

\section{Victoria}

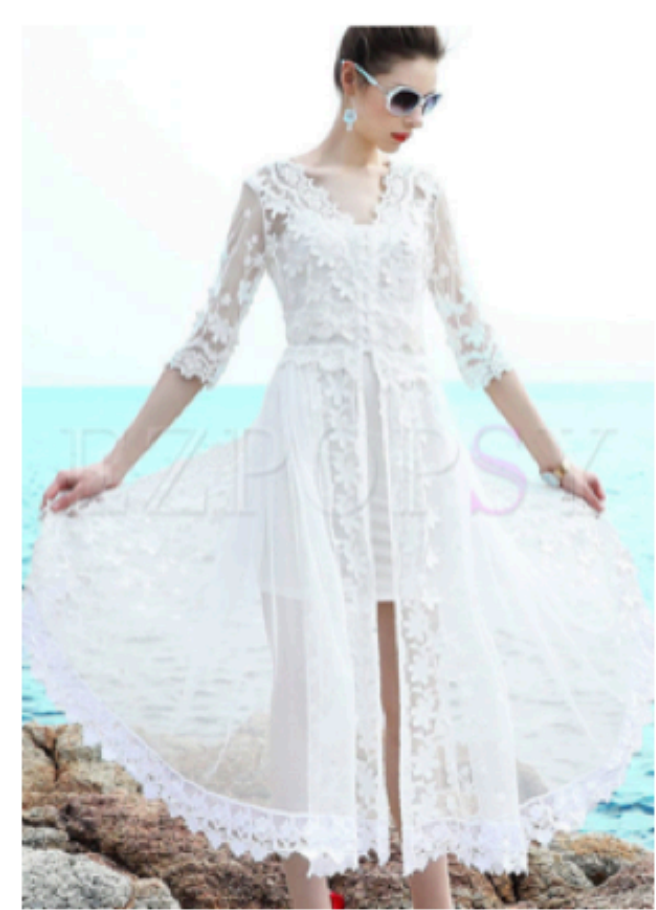

Research Image 65

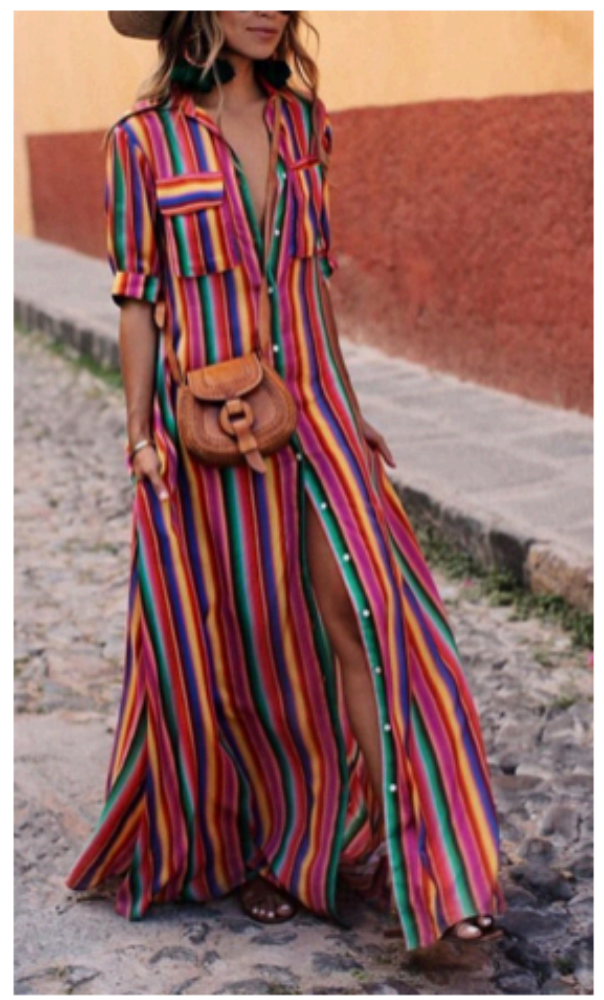

Research Image 67

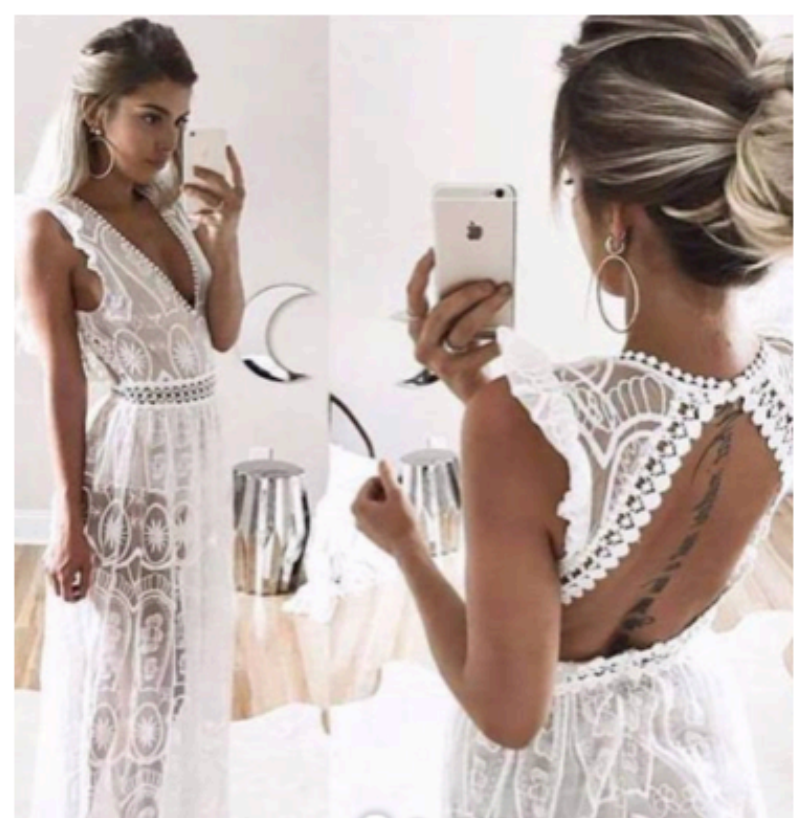

Research Image 66

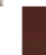

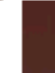




\section{CLOUD $\mathbb{N} \| \mathbb{N}$}

\section{TCTORIA}

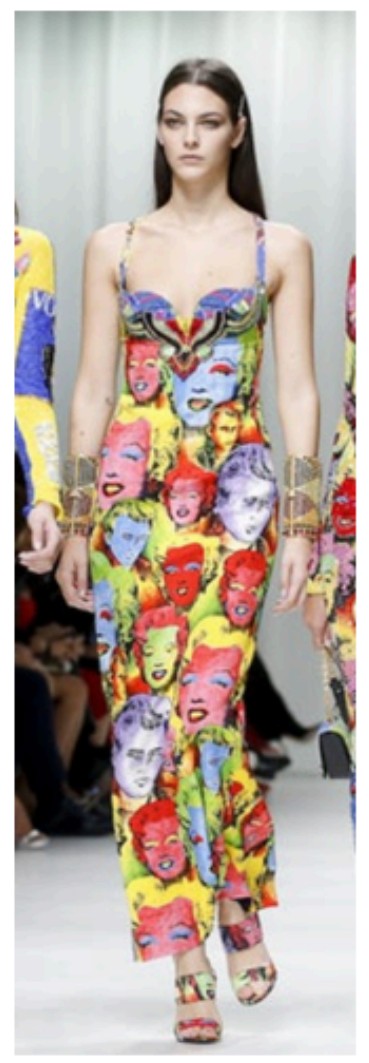

Research Image 70

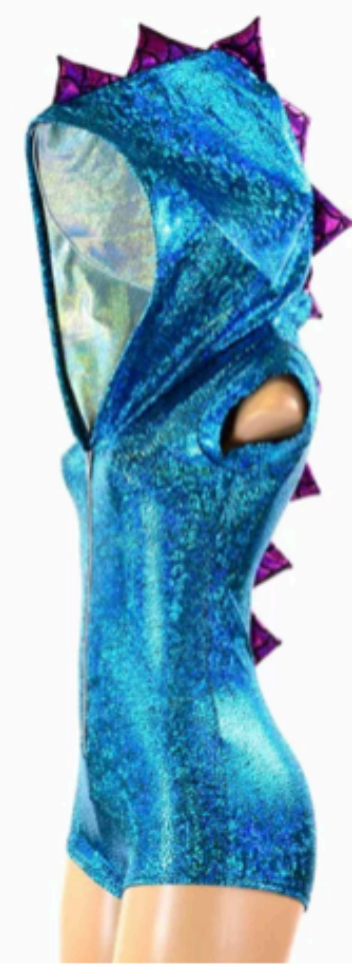

Research Image 74

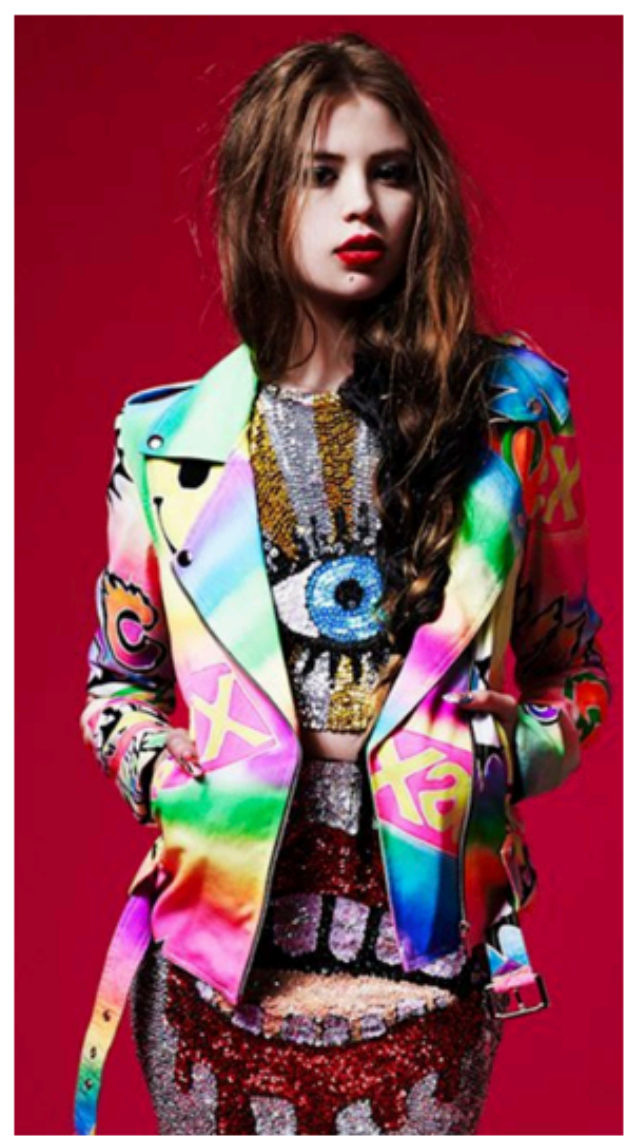

Research Image 71

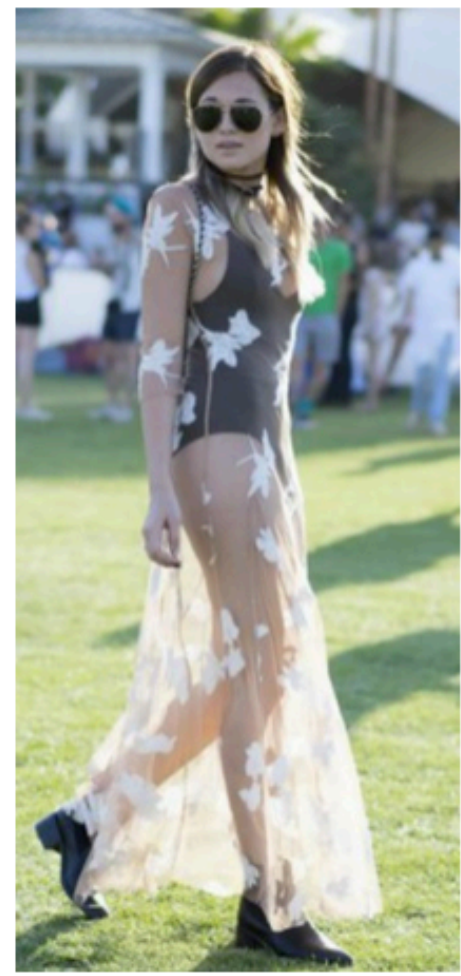

Research Image 72

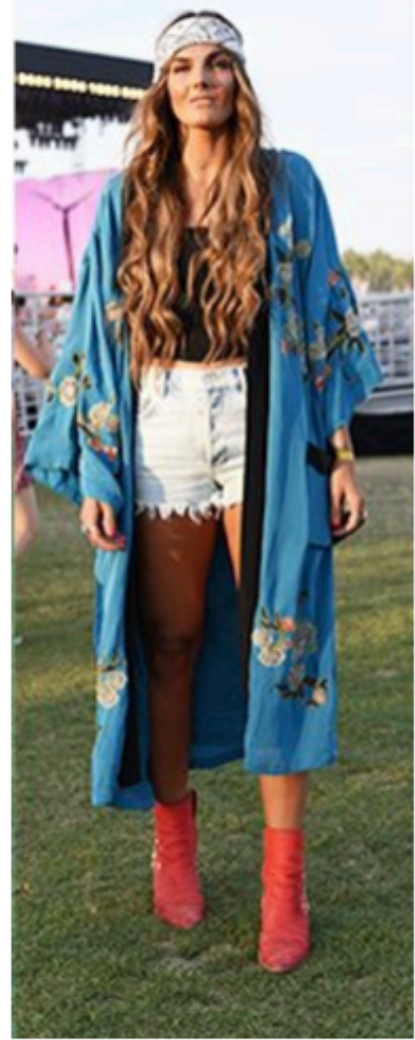

Research Image 73

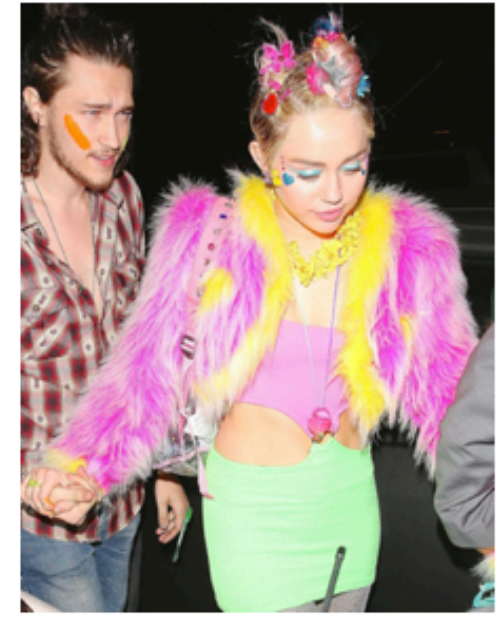

Research Image 75

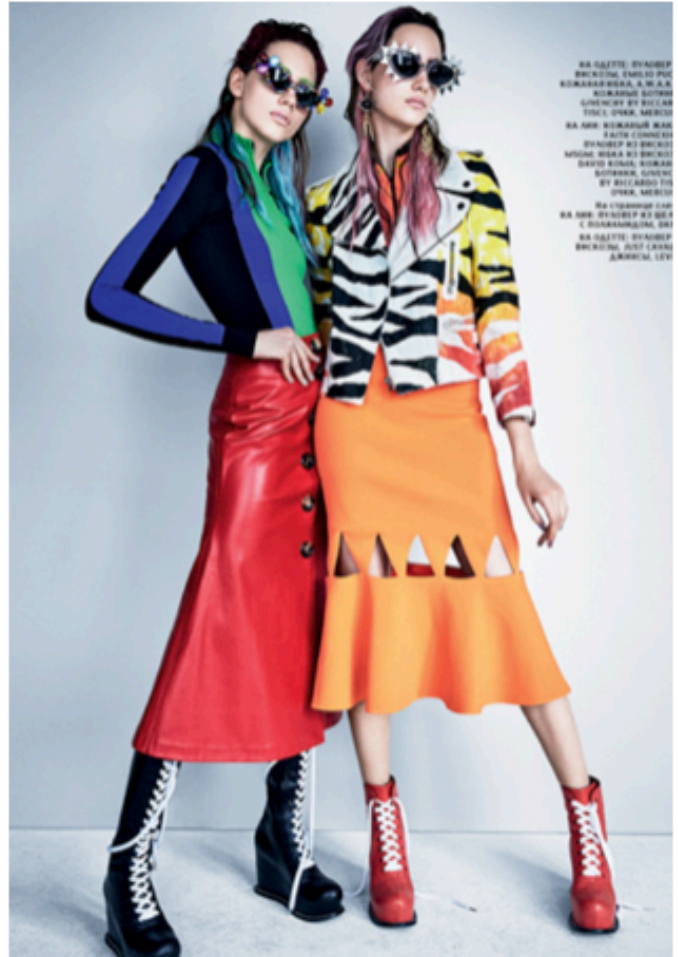

Research Image 76 


\section{Cloud Nine}

Martin

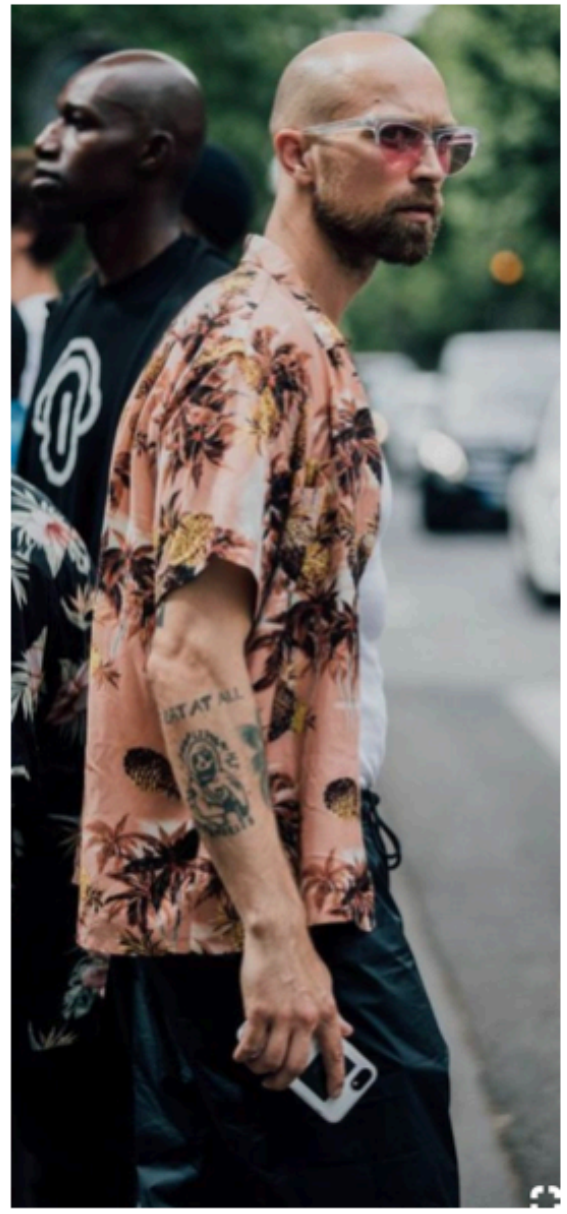

Research Image 77

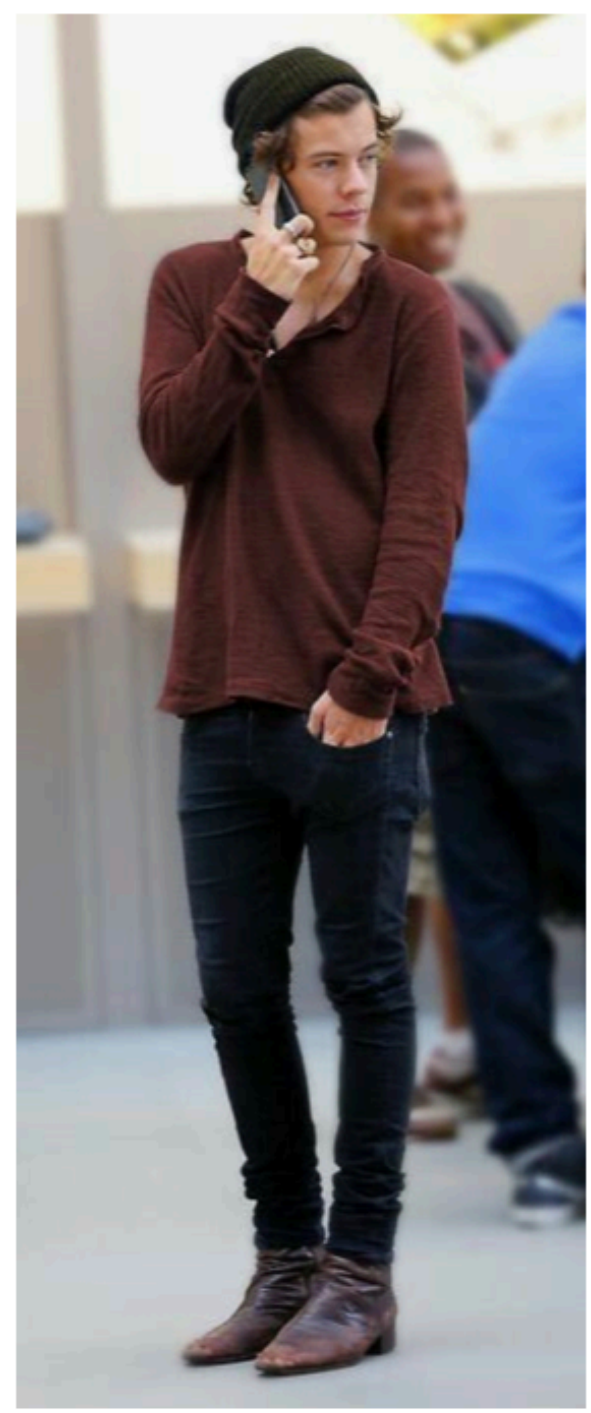

Research Image 78

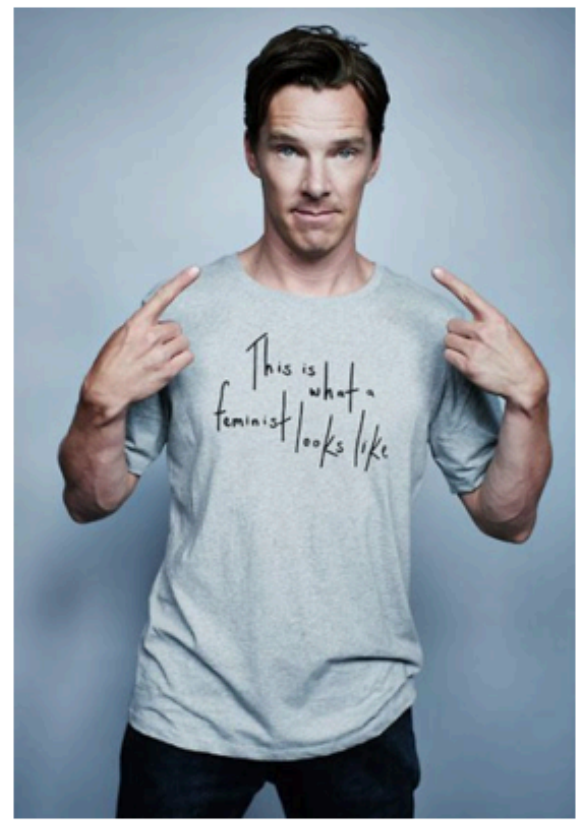

Research Image 79

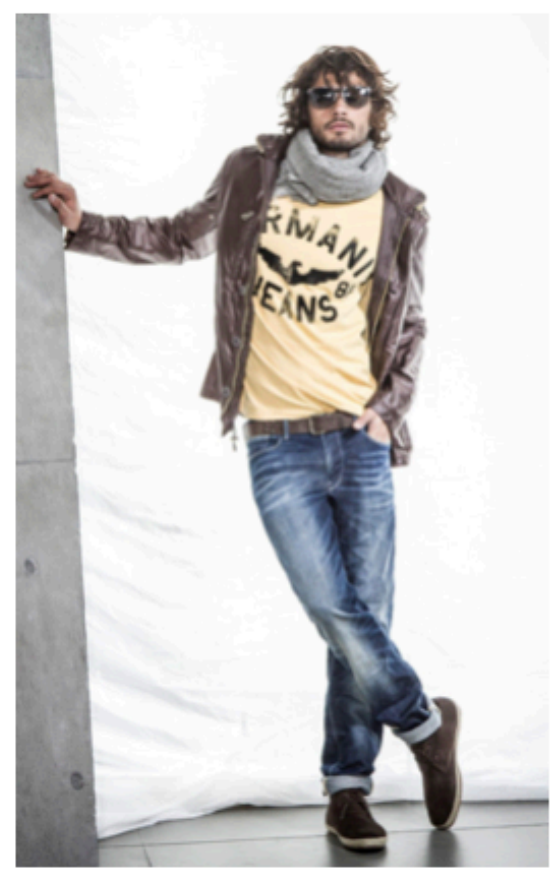

Research Image 81 


\section{CLOUD NINE}

\section{MARTIN}

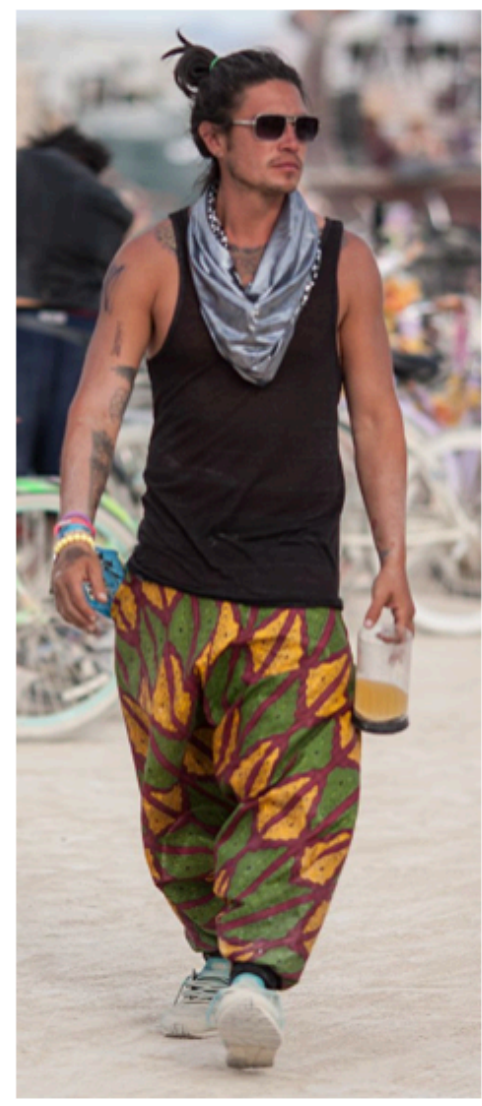

Research Image 82
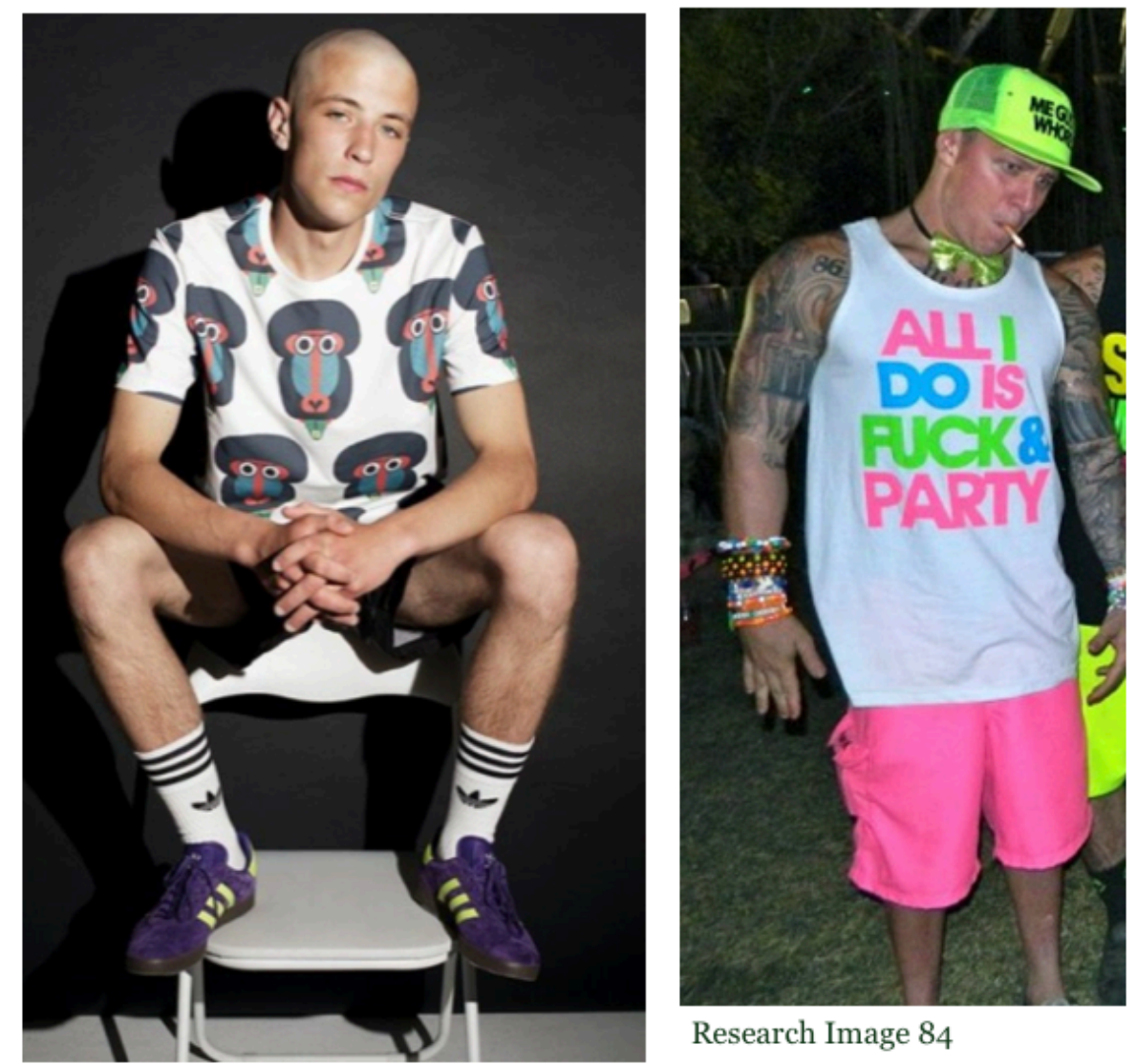

Research Image 84

Research Image 83

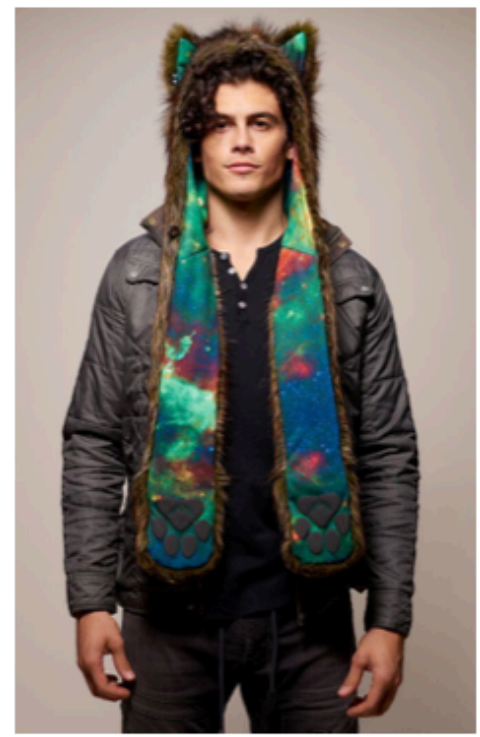

Research Image 85

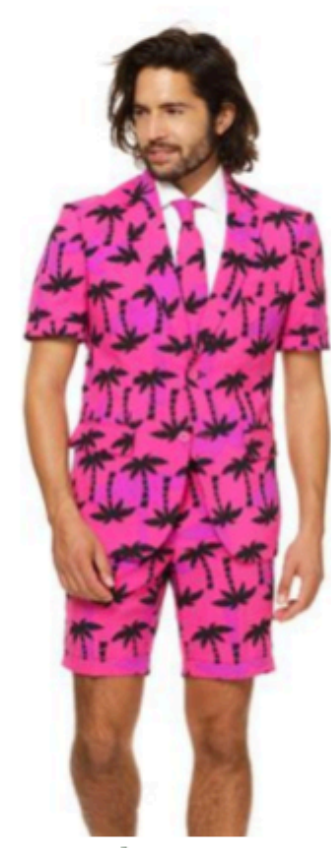

Research Image 86 


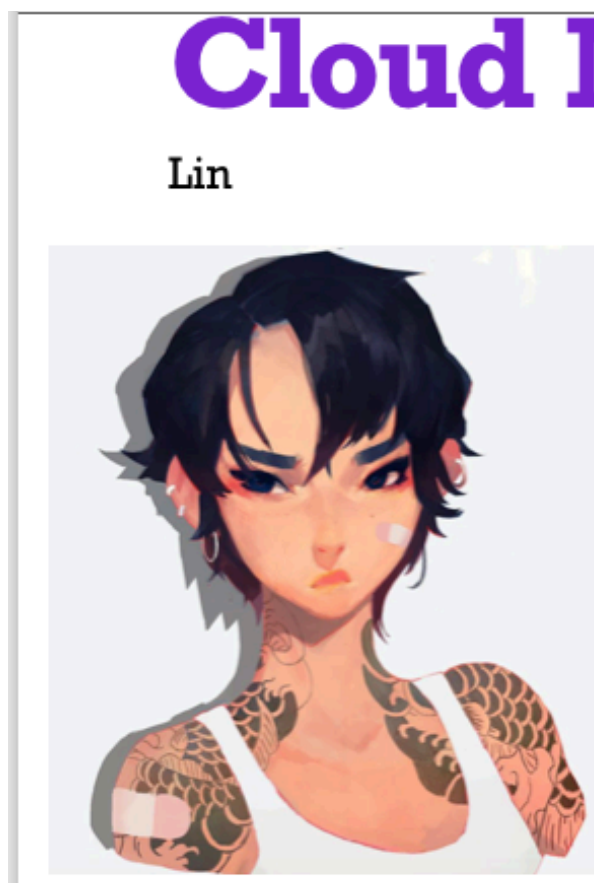

Research Image 87

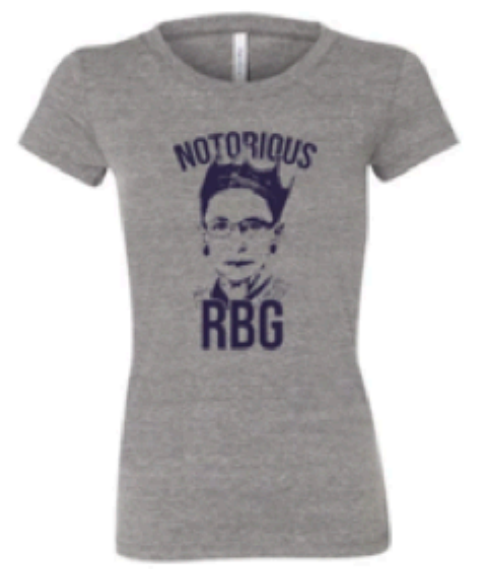

Research Image 90

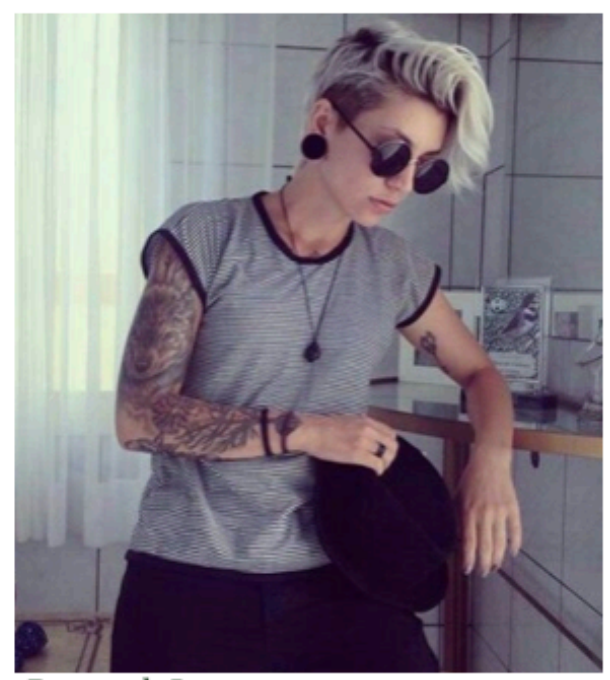

Research Image 92

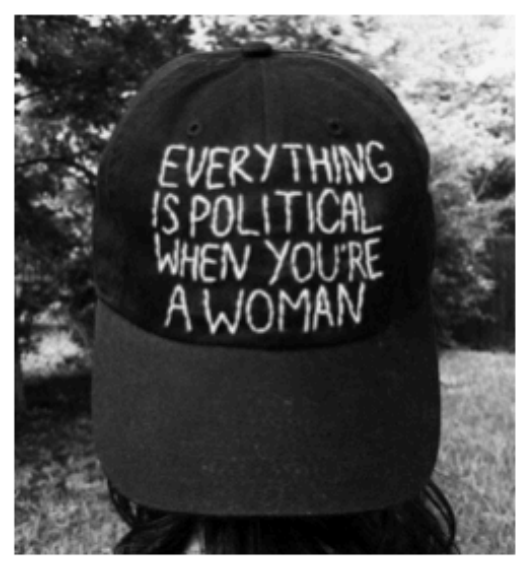

Research Image 88

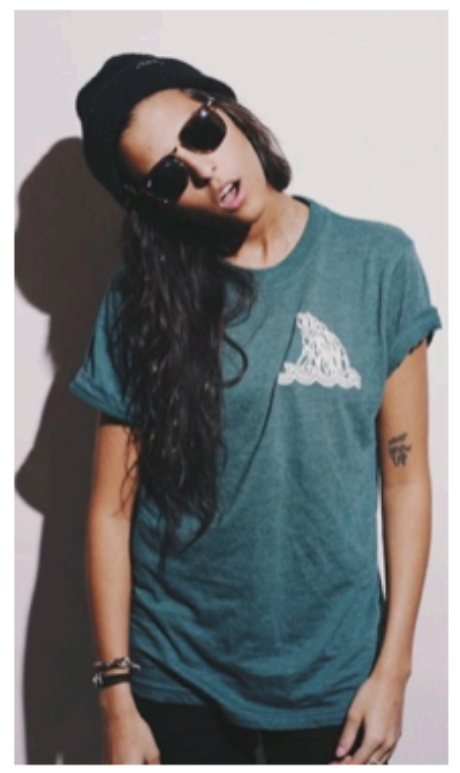

Research Image 91

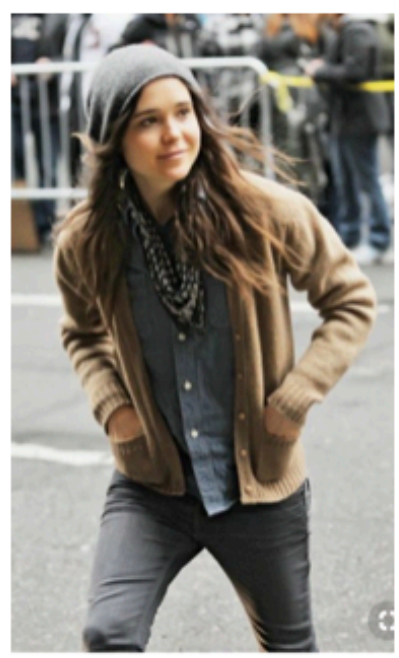

Research Image 93

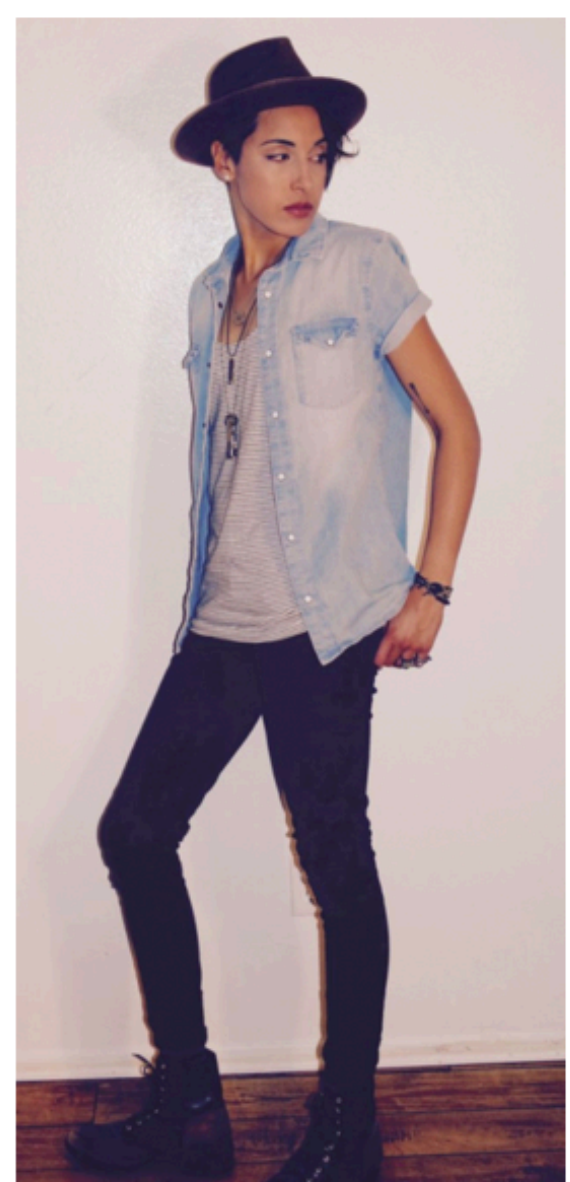

Research Image 89

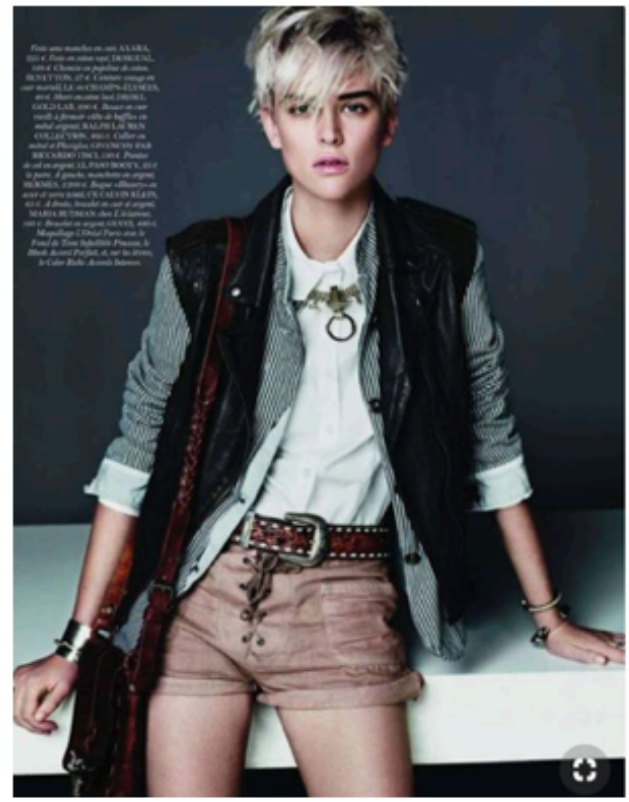

Research Image 94 


\section{Cloud Nine}

Lin

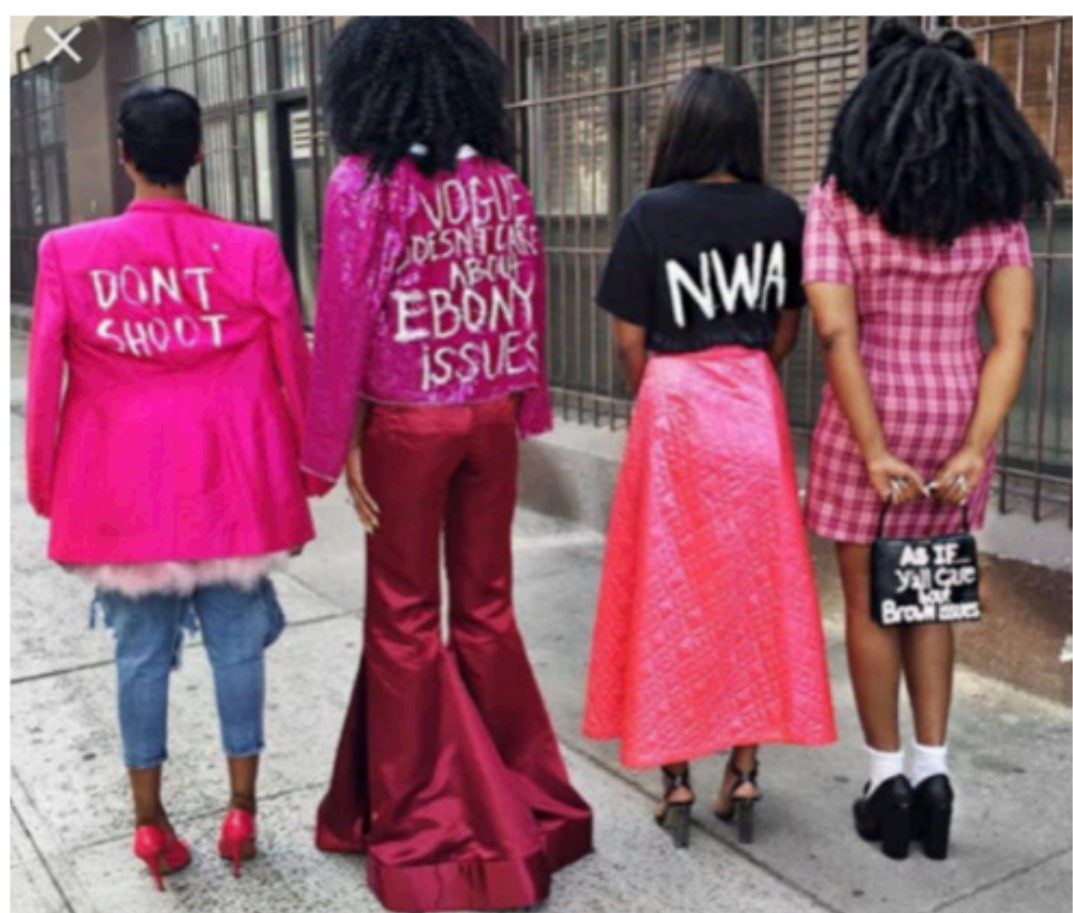

Research Image 95

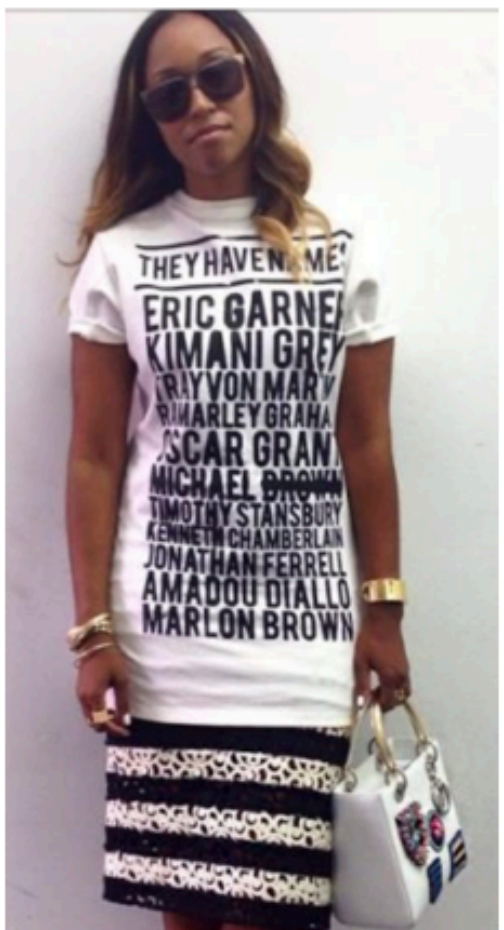

Research Image 96

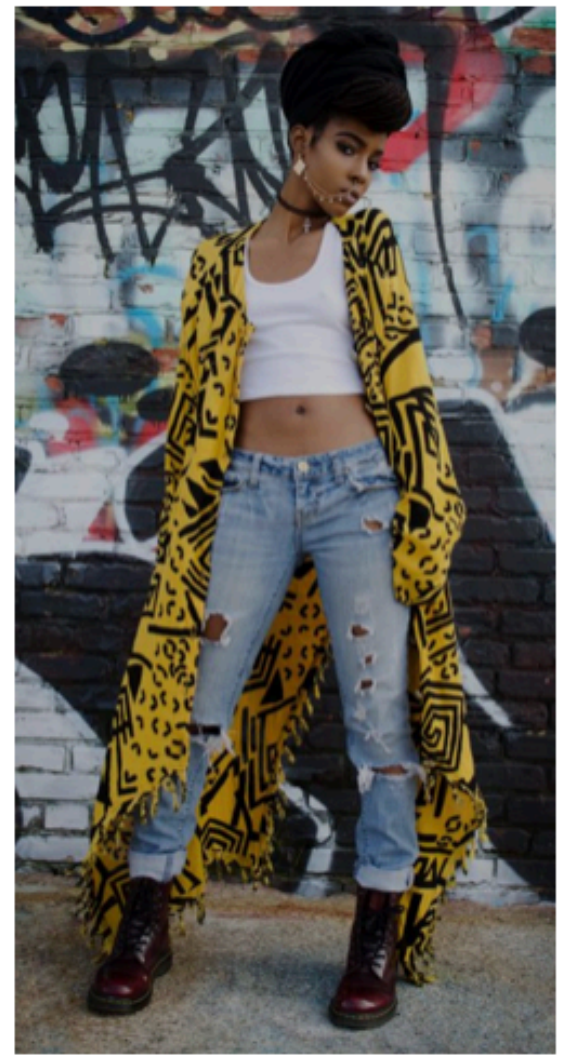

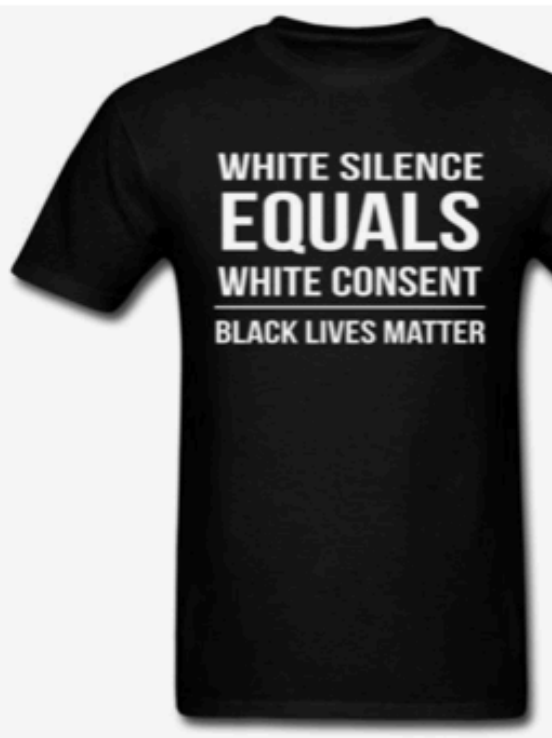

Research Image 98

Research Image 97

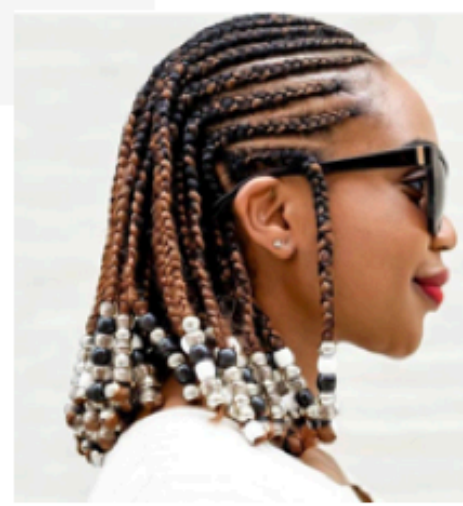

Research Image 99 


\section{CLOUD $\mathbb{N} \| \mathbb{N}$ E}

ㄴN

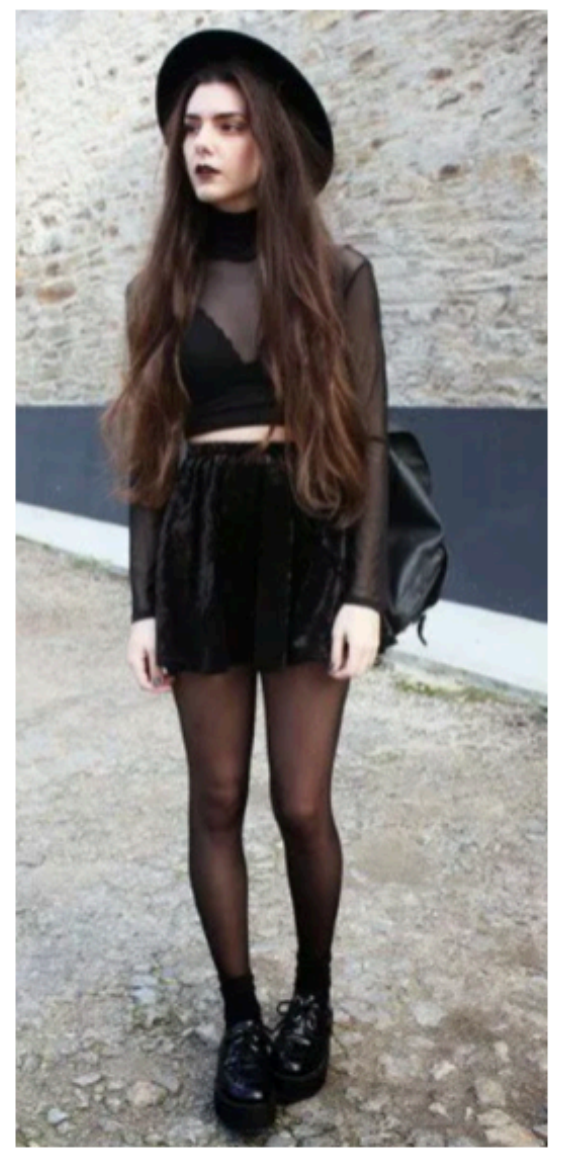

Research Image 100

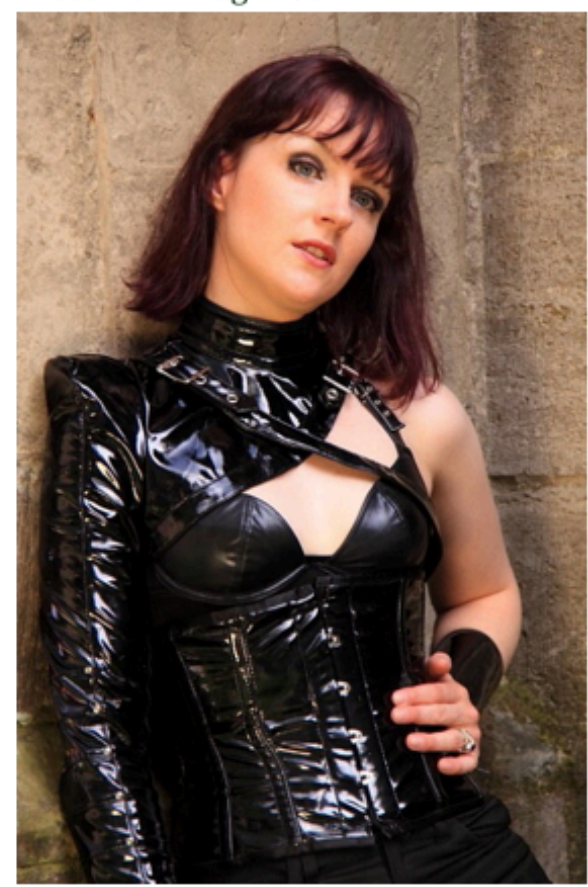

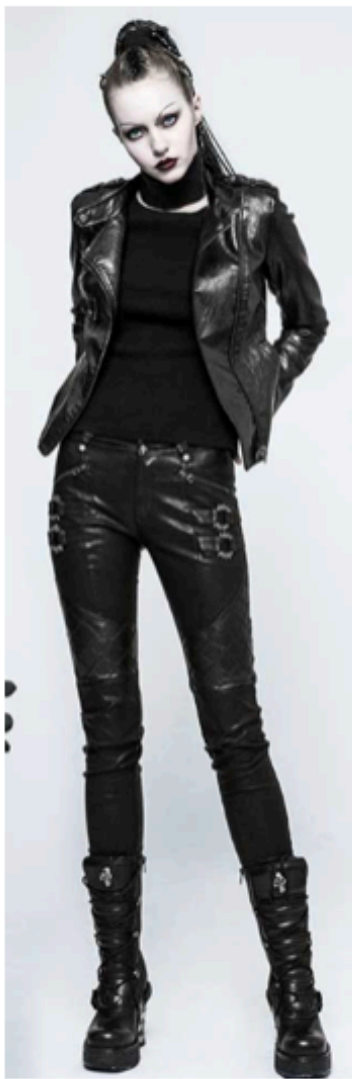

Research Image 101

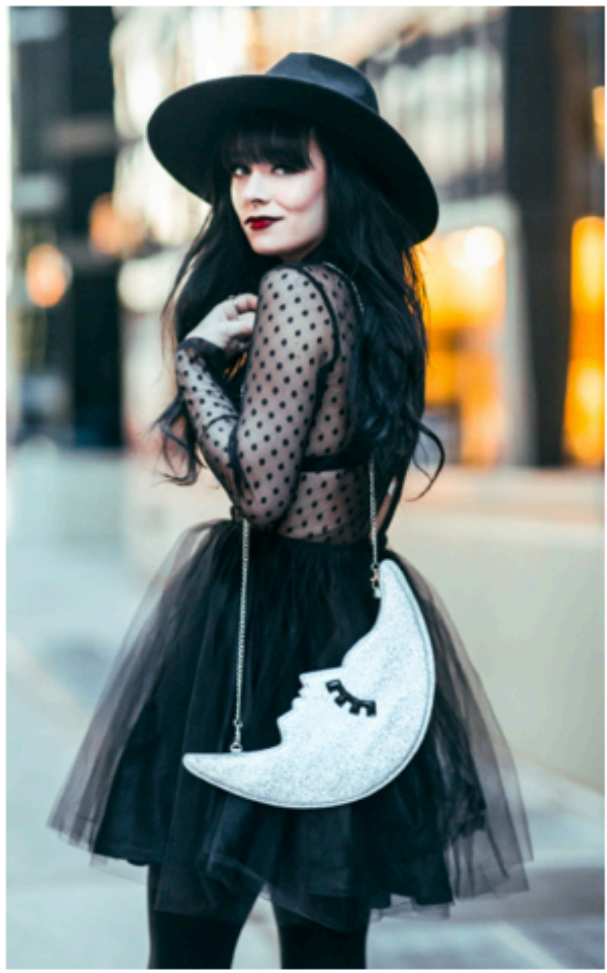

Research Image 102

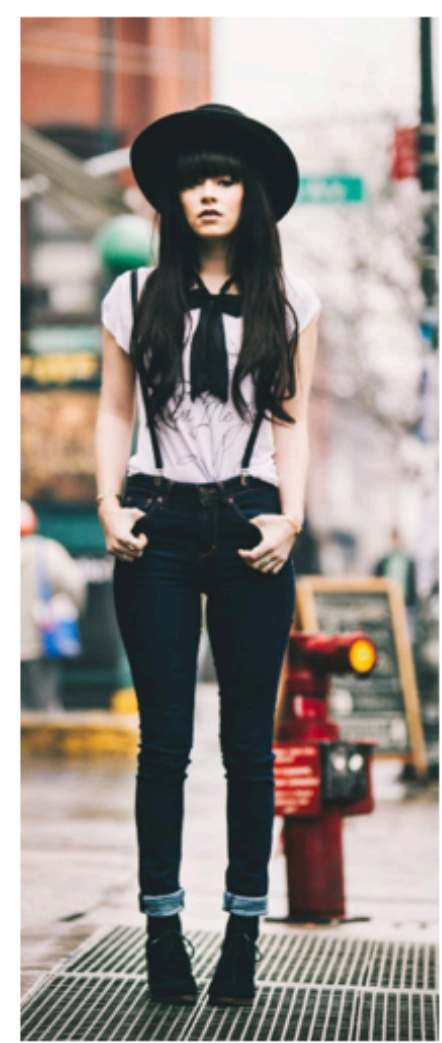

Research Image 104 


\section{Cloud Nine}

Cathy

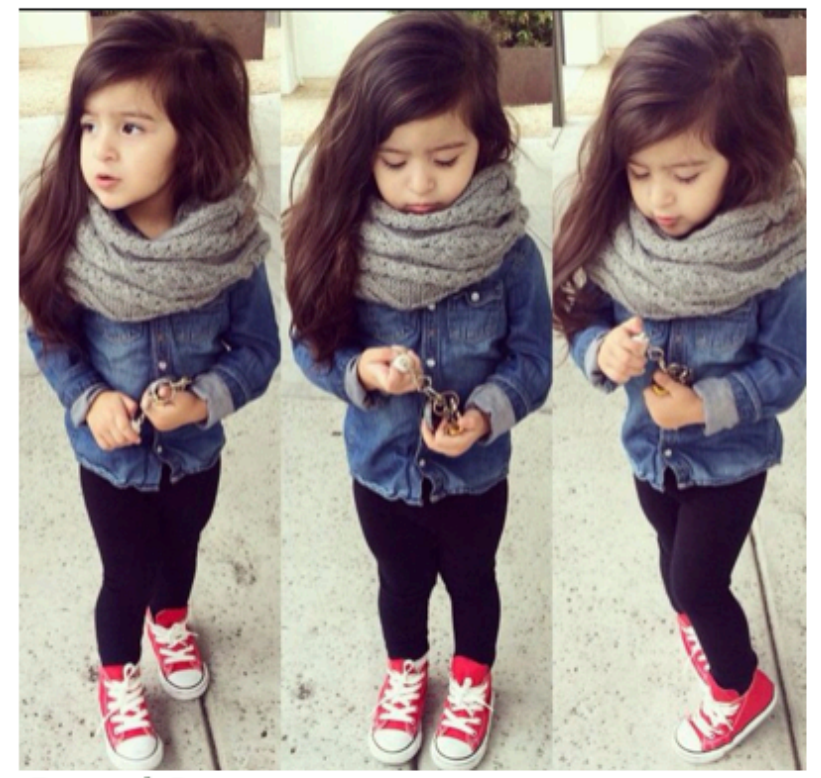

Research Image 105

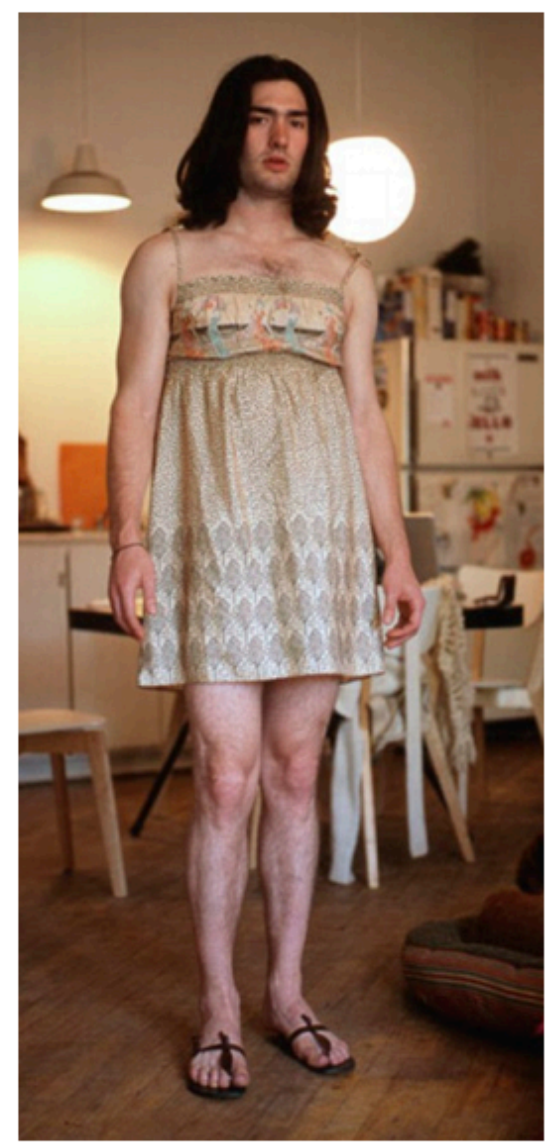

Research Image 107

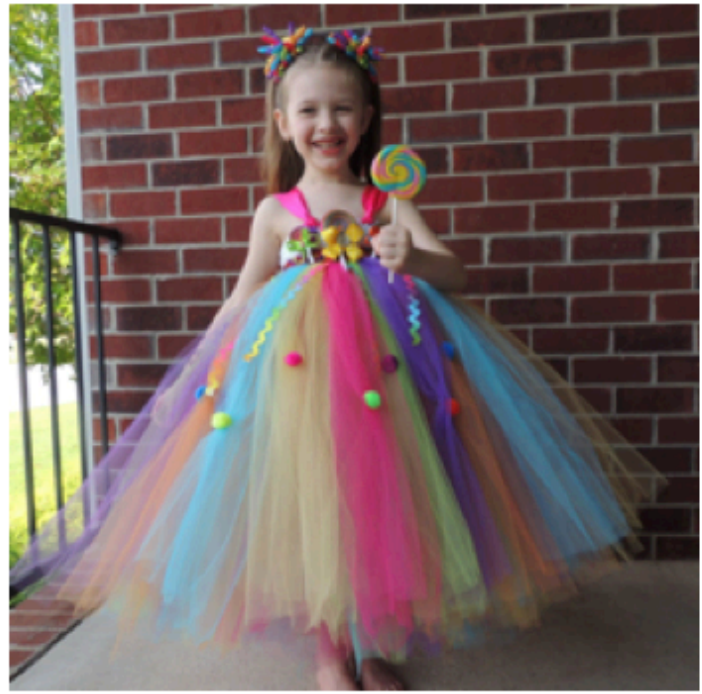

Research Image 106

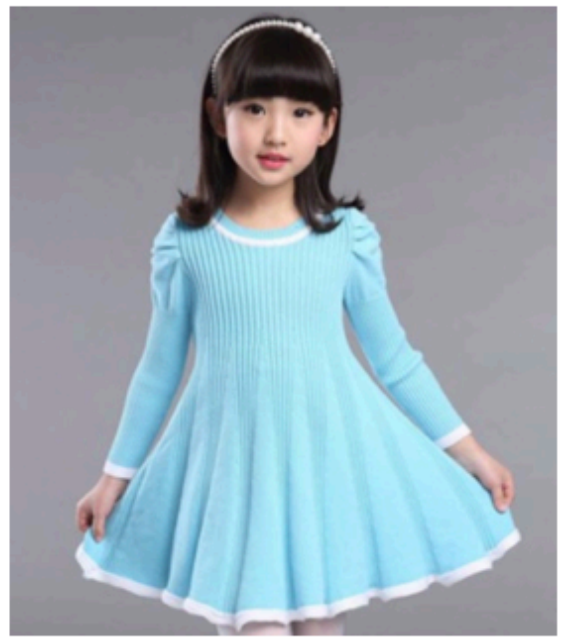

Research Image 108

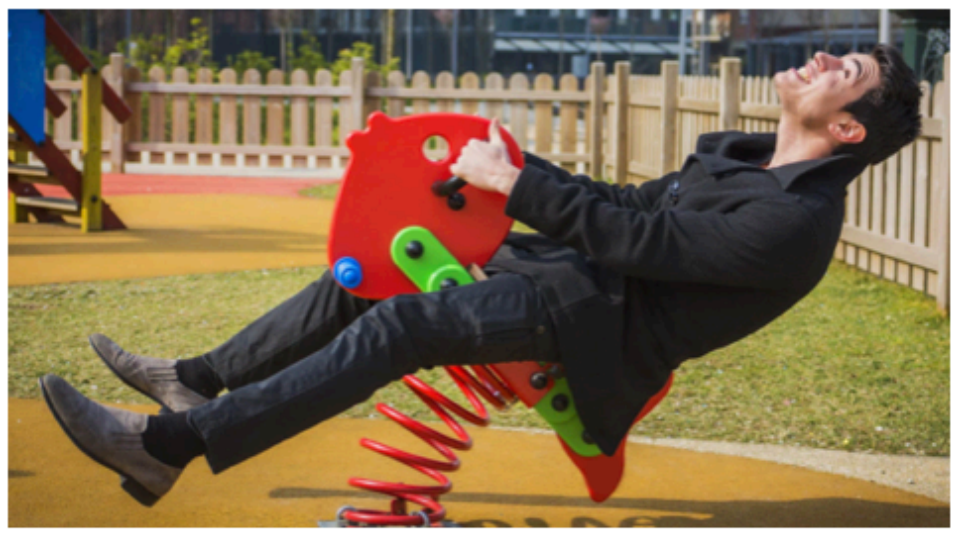

Research Image 109 


\section{CLOUDD NINE}

\section{CATHY}

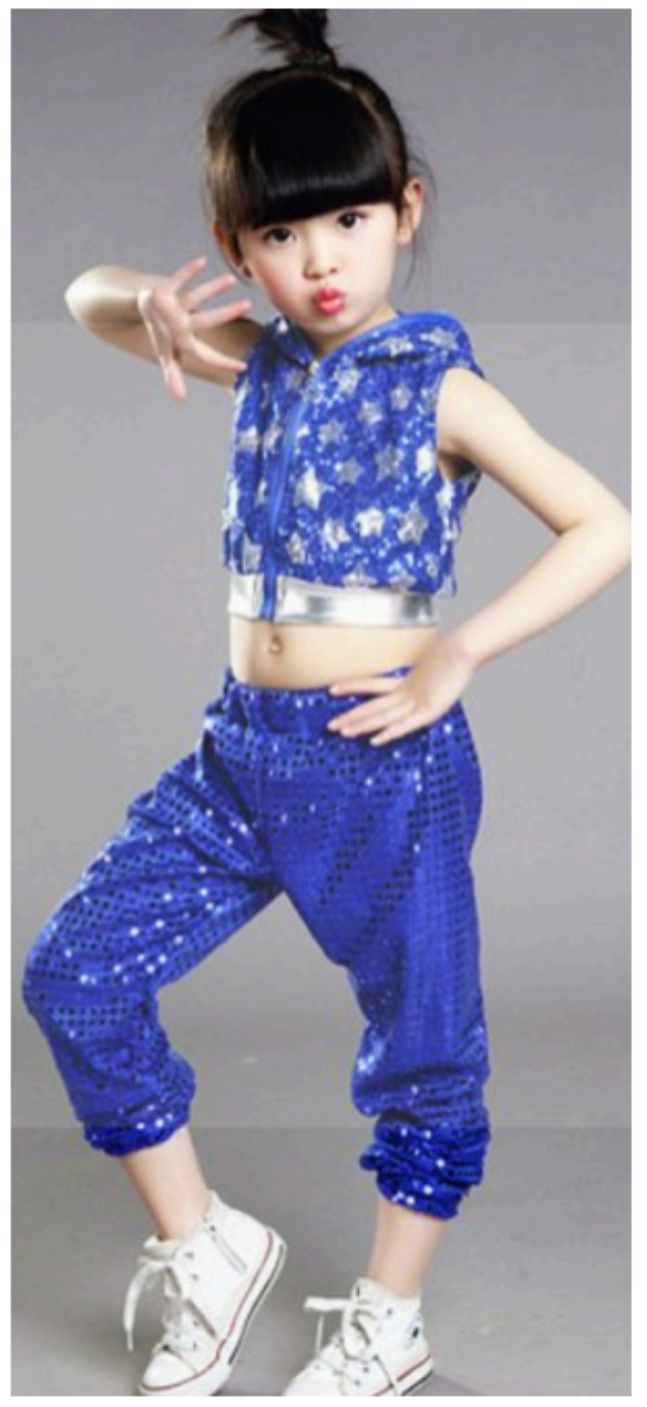

Research Image 110

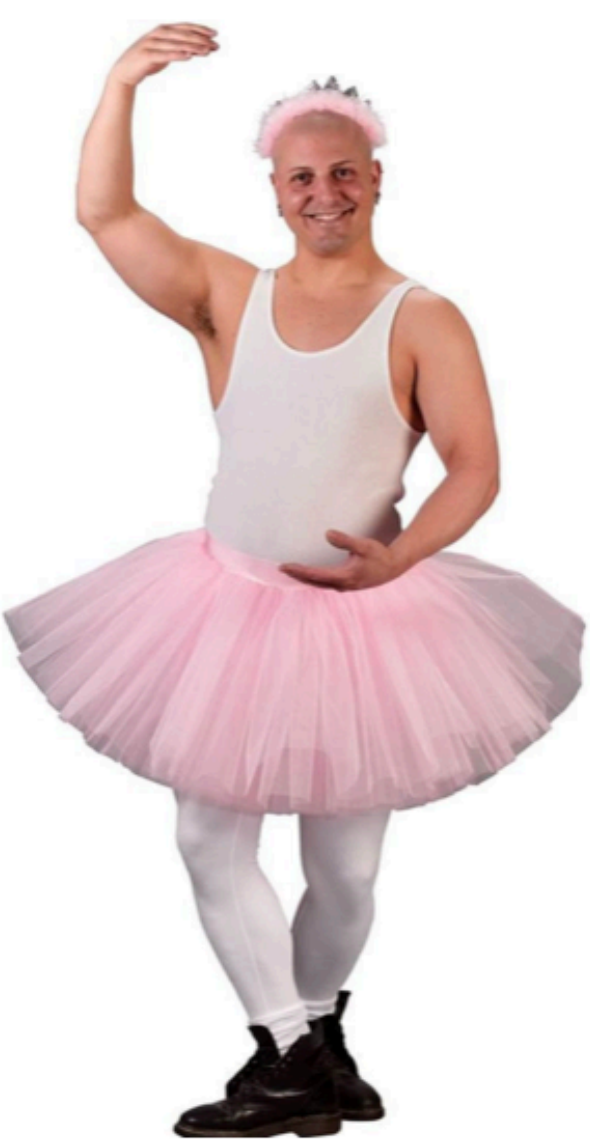

Research Image 111

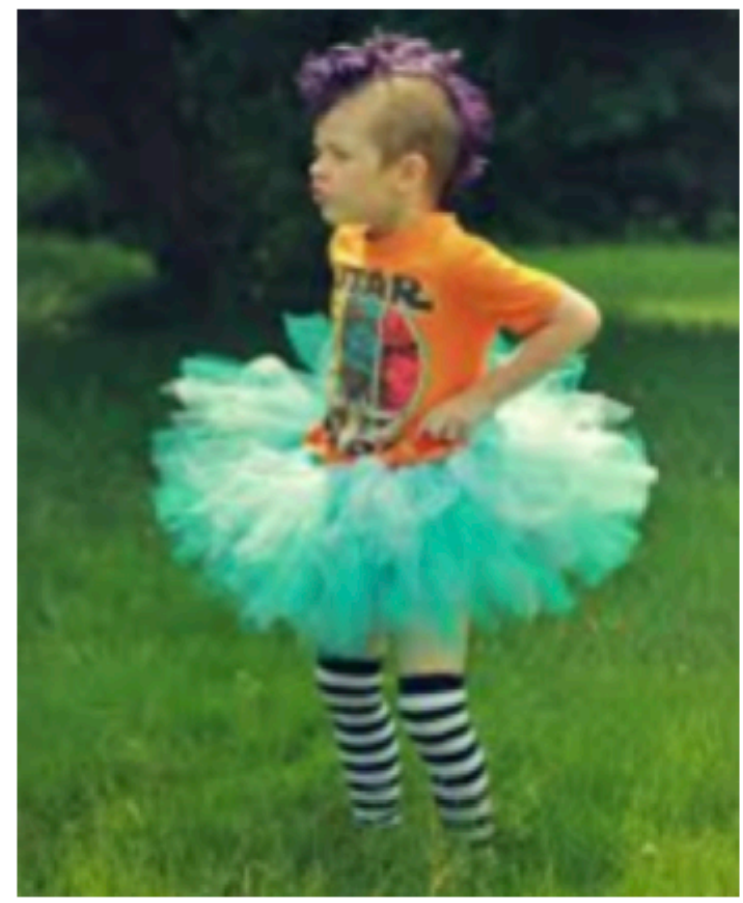

Research Image 112 

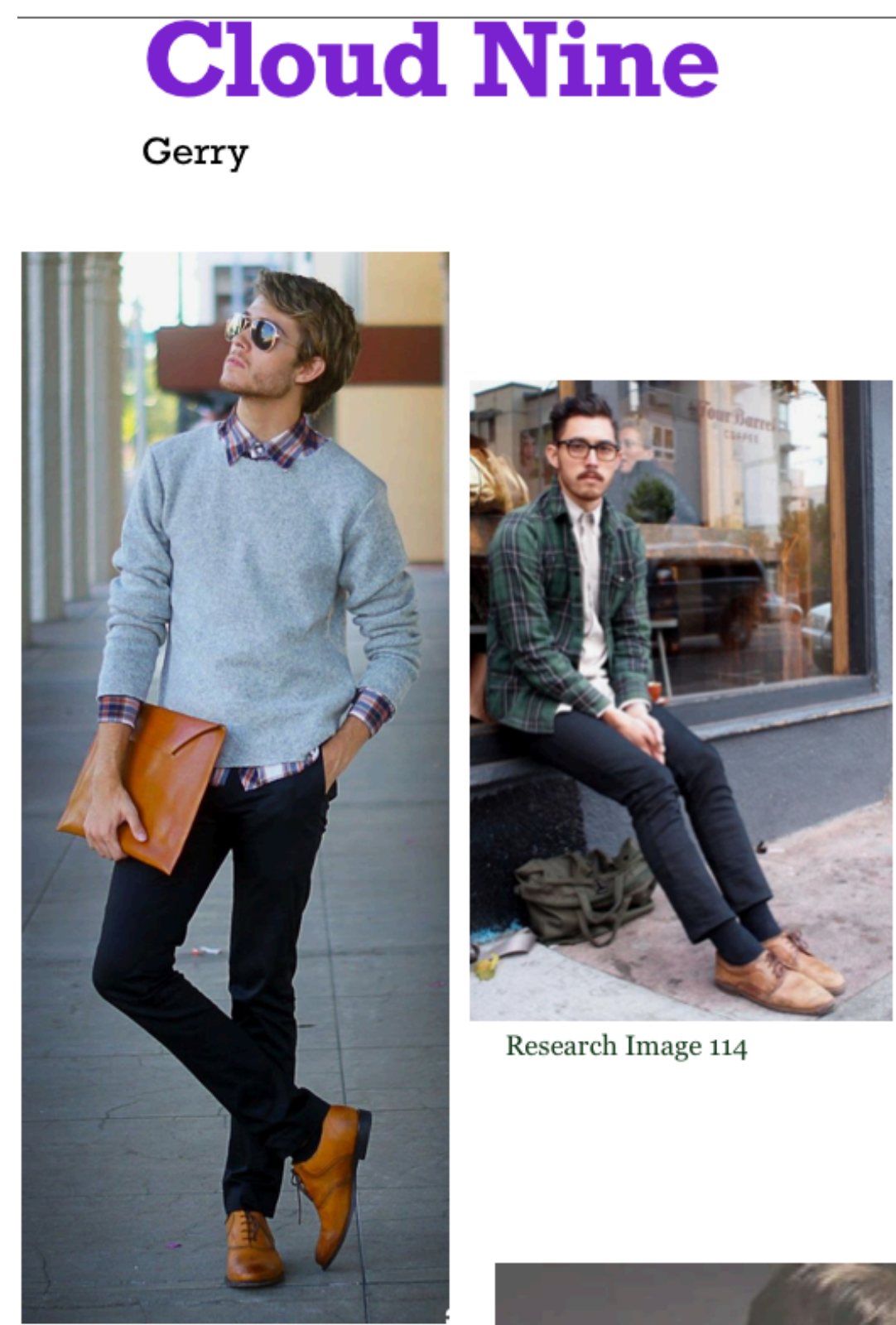

Research Image 114

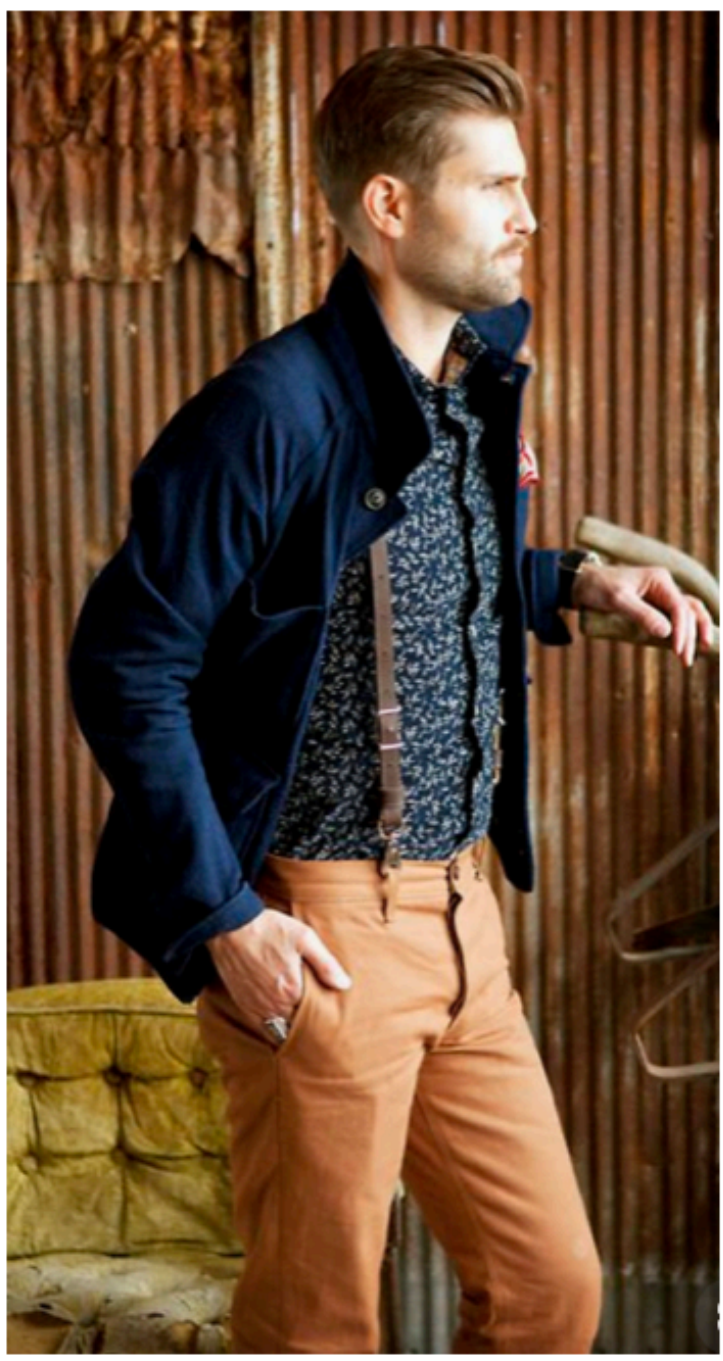

Research Image 115

Research Image 113

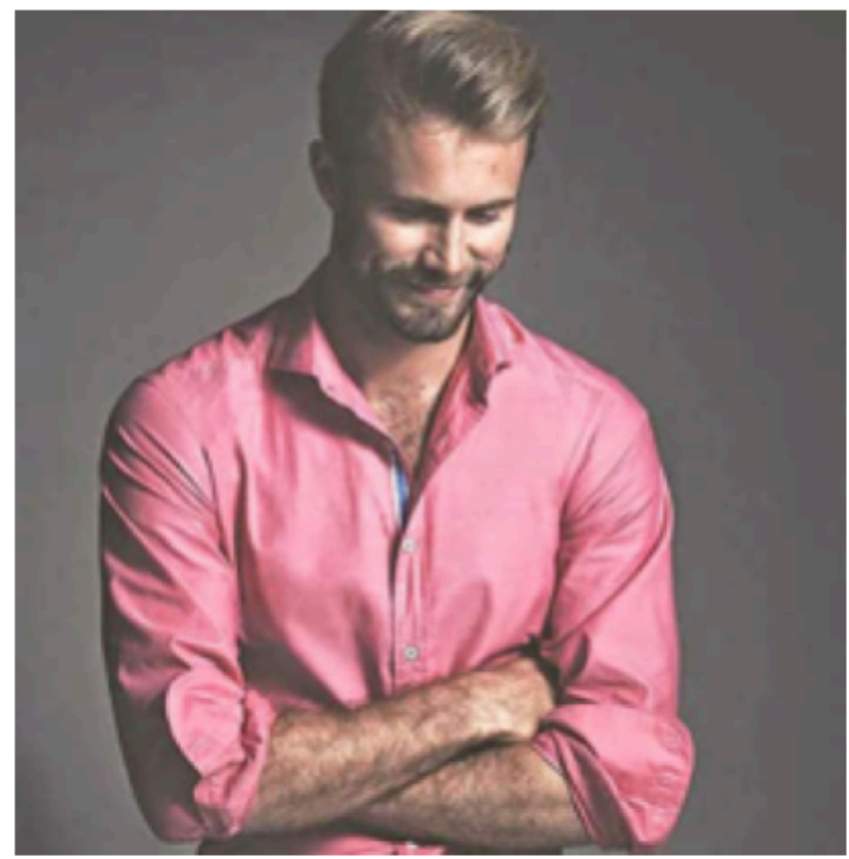

Research Image 116 


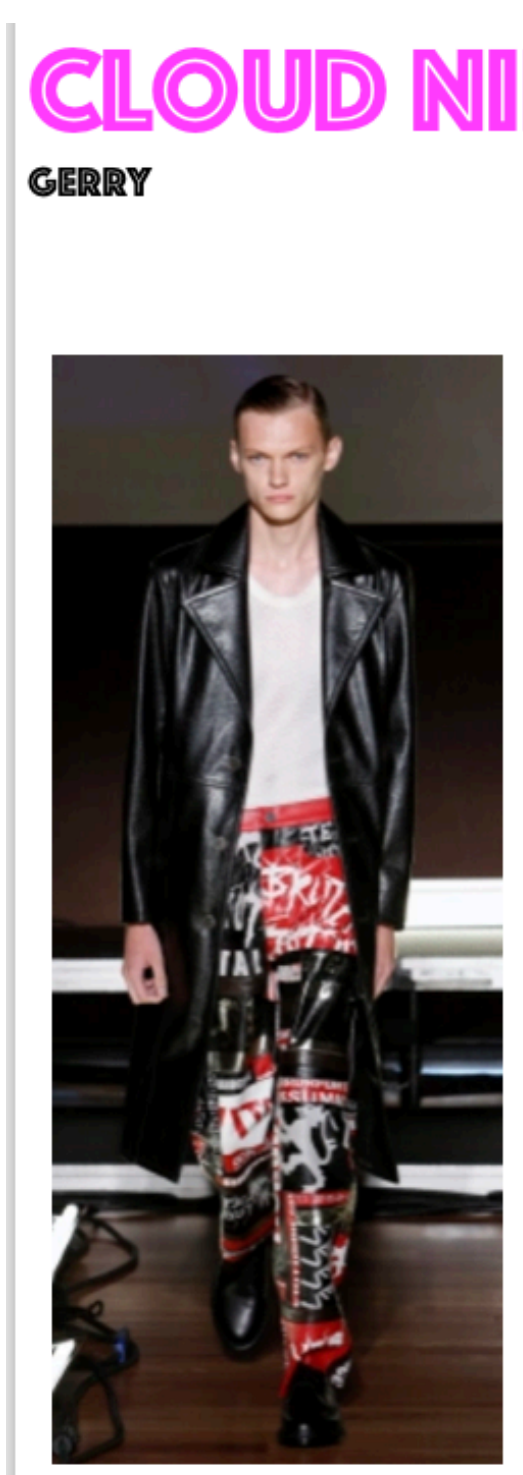

Research Image 117

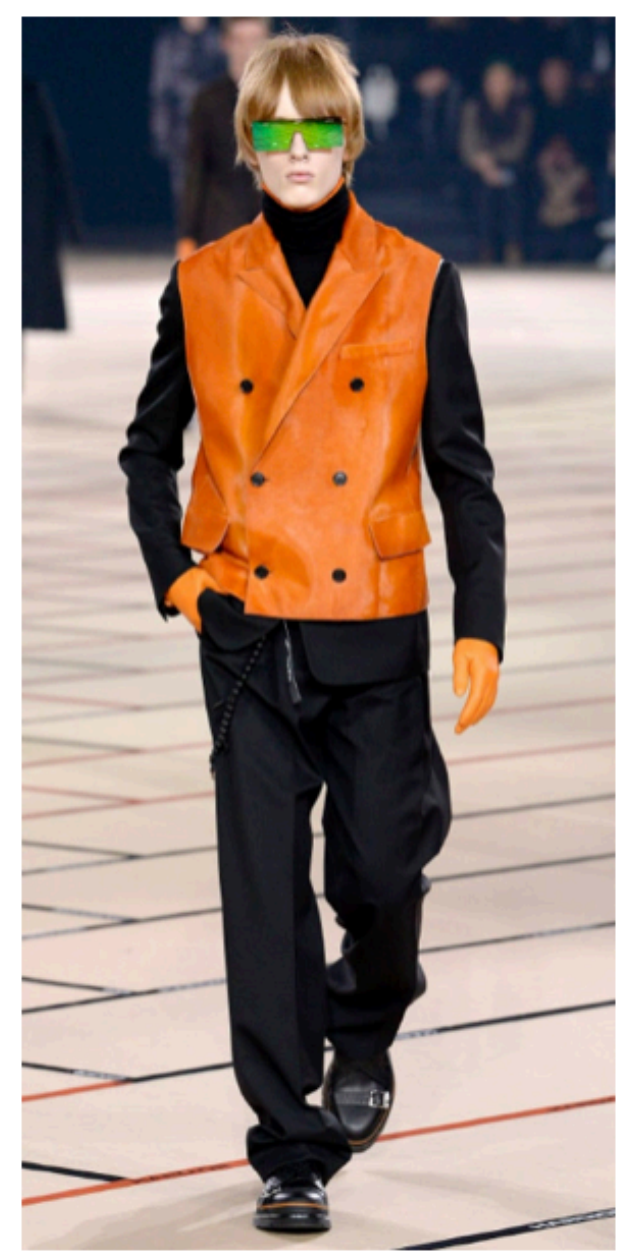

Research Image 118

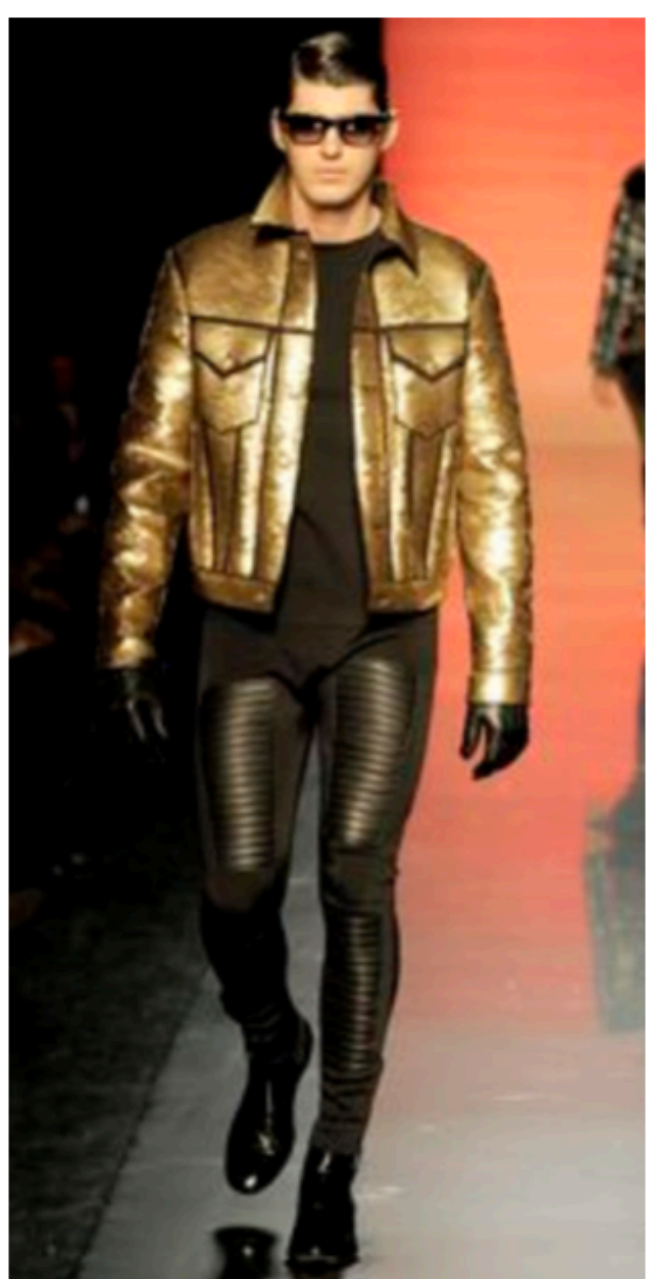

Research Image 120

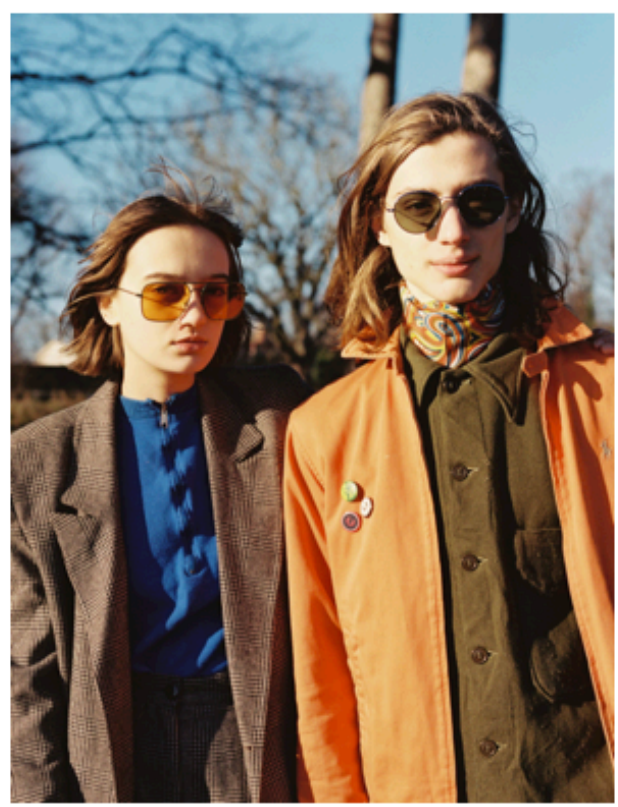

Research Image 119 


\section{Cloud Nine}

Lin's Brother, Dead Soldier

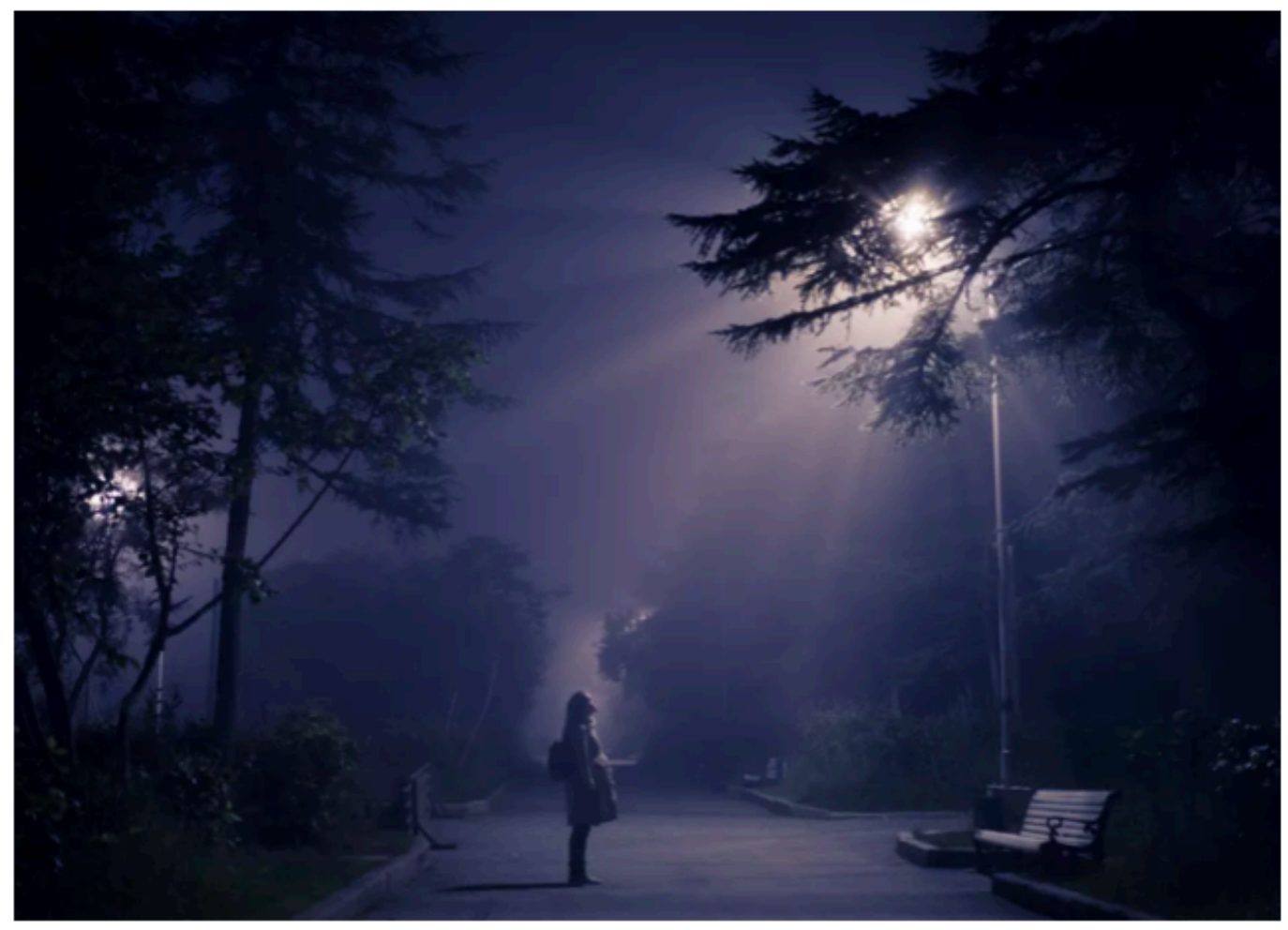

Research Image 121
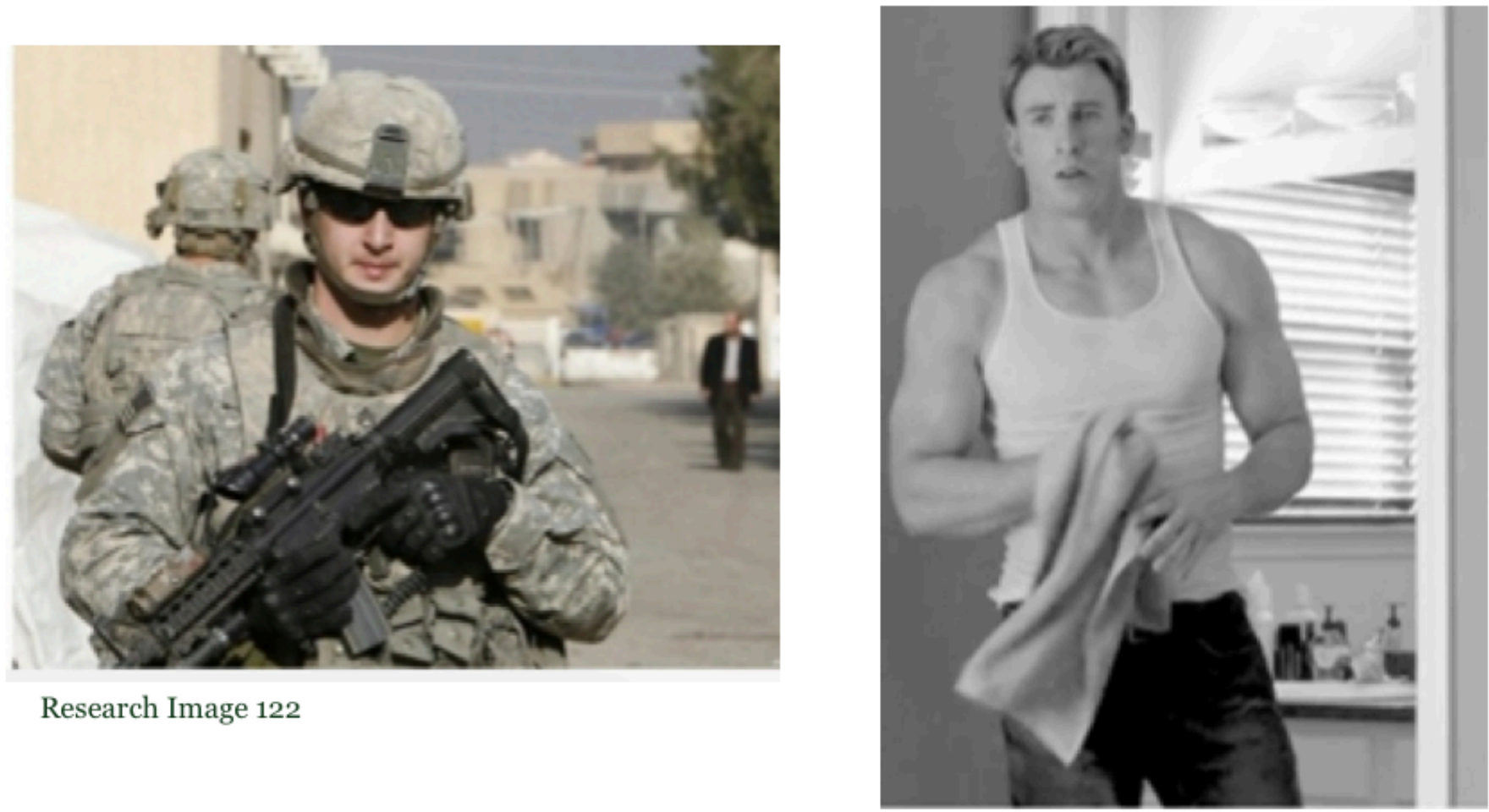

Research Image 122 


\section{Appendix C: "Look Books" Research Images Works Cited}

\section{Research Image 1}

Library, University of Glasgow. “Captain Robert Gibson.” Flickr, Yahoo!, 10 Mar. 2010, https://www.flickr.com/photos/uofglibrary/4422082209.

\section{Research Image 2}

Uchenna, Nzekwe Gerald. “THE ORIGIN AND GROWTH OF SECRET SOCIETIES IN NIGERIA." "HISTORY -- With Nzekwe Gerald Uchenna, Thread, 2018, https:// threadreaderapp.com/thread/1017805676331044865.html.

\section{Research Image 3}

Sharif, Al, and Raad Al Anbaky. "The Real American Heiresses Who Saved the British Aristocracy - Mary Leiter, Baroness Curzon." The Crown Chronicles, London Reign Communications Ltd, 1 Aug. 2016, https://thecrownchronicles.co.uk/history/historyposts/american-heiresses-saved-british-aristocracy-mary-leiter-baroness-curzon/.

\section{Research Image 4}

AMES, Adelbert - Biographical Information, Biographical Directory of the United States Congress, http://bioguide.congress.gov/scripts/biodisplay.pl?index=a000172. 


\section{Research Image 5}

David Livingstone. 1860, London Stereoscopic \& Photographic Company, London .

\section{Research Image 6}

“All- Modern African Print Clothing." D'IYANU, https://www.diyanu.com/collections/all/ men?page $=1 \&$ sort_by $=$ created-descending.

\section{Research Image 7}

Hanebutt, Jacob. "Mary Kingsley." Women in European History RSS, 2 June 2010, http:// womenineuropeanhistory.org/index.php?title=Mary_Kingsley.

\section{Research Image 8}

Kumorek, Karolina. “Trevillion Images .” Trevillion Images, Infradox, https:// www.trevillion.com/search?s=karolina + kumorek.

\section{Research Image 9}

Bobbins, Beth. "Hairstyling: Braids for a Young Lady, 1860." Hairstyling: Braids for a Young Lady, 1860, Blogspot, 24 June 2015, http://bethsbobbins.blogspot.com/2015/06/ hairstyling-braids-for-young-lady-1860.html. 


\section{Research Image 10}

E., Sara. "Fashion from the 1880s." ...If He Did like Her, He Should Have Her..., Word Press, 25 Mar. 2012, https://historiful.wordpress.com/2012/04/07/fashion-from- the-1880s/.

\section{Research Image 11}

The Miriam and Ira D. Wallach Division of Art, Prints and Photographs: Picture Collection, The New York Public Library. "Walking-Dress ; House-Dress For Elderly Woman." The New York Public Library Digital Collections. 1889. http://

digitalcollections.nypl.org/items/510d47e0-e4e7-a3d9-e040-e00a18064a99

\section{Research Image 12}

Morris, Henry. Kalulu (Ndugu M'hali). National Portrait Gallery, London, https:// www.npg.org.uk/collections/search/use-this-image.php?mkey=mw70351.

\section{Research Image 13}

Morris, Henry. "Kalulu (Ndugu M'hali).” National Portrait Gallery, https:// www.npg.org.uk/collections/search/use-this-image.php?mkey=mw70351.

\section{Research Image 14}

Acolatse, Alex Agbaglo. “Two Dapper Young Men Leaning on a Chair.” The Met, Metropolitain Museum of Art, Togo, https://www.metmuseum.org/toah/works-of-art/ 2015.499.24.1/. 


\section{Research Image 15}

Shonibare, Yinka. 2006, Sindika Dokolo African Collection of Contemporary Art.

\section{Research Image 16}

“Anthology Fabrics Quilt Essentials Batiks Charcoal Grommets." Hancock's of Paducah, Hancock's of Paducah, 2019, https://www.hancocks-paducah.com/Anthology-FabricsQuilt-Essentials-Batiks-Charcoal-Grommets quantity $=1 \&$ custcol_tt_itemoption_decimals $=1$.

\section{Research Image 17}

“Henry Morton Stanley Books.” Shakari Connection, 2008, https:// www.shakariconnection.com/henry-morton-stanley-books.html.

\section{Research Image 18}

Burton, Peter. "Explorers of the Nile: The Triumph and Tragedy of a Great Victorian Adventure.” Express.co.uk, Express.co.uk, 19 Sept. 2011, https://www.express.co.uk/ entertainment/books/271646/Explorers-of-the-Nile-The-Triumph-and-Tragedy-of-aGreat-Victorian-Adventure.

\section{Research Image 19}

“WikiVisually.com.”WikiVisually, 2019, https://wikivisually.com/wiki/Chuma_and_Susi. 


\section{Research Image 20}

Granger. “0052063 - HENRY MORTON STANLEY (1841-1904) and Sidi Mubarak Bombay (1820-1885) on the 1871 Expedition into Central Africa to Search for David Livingstone. Wood Engraving after Godefroy Durand, 1890.” Historical Picture Archive, 20/20 Software, 2019, https:/www.granger.com/results.asp?image=0052063.

\section{Research Image 21}

Parsons, Chris. "Rogues Gallery of Fagins Children: Mugshots of Victorian Criminals Shows Thieves as Young as 11 Who Were Jailed for Stealing Clothes, Cash and Metal.” Daily Mail Online, Associated Newspapers, 27 June 2012, https:// www.dailymail.co.uk/news/article-2165262/Rogues-gallery-Fagins-children-MugshotsVictorian-criminals-shows-thieves-young-11-jailed-stealing-clothes-cash-metal.html.

\section{Research Image 22}

Parsons, Chris. "Rogues Gallery of Fagins Children: Mugshots of Victorian Criminals Shows Thieves as Young as 11 Who Were Jailed for Stealing Clothes, Cash and Metal.” Daily Mail Online, Associated Newspapers, 27 June 2012, https:// www.dailymail.co.uk/news/article-2165262/Rogues-gallery-Fagins-children-MugshotsVictorian-criminals-shows-thieves-young-11-jailed-stealing-clothes-cash-metal.html. 


\section{Research Image 23}

“Late Victorian Era Fashion Facts: Women's, Men's, Girl' s, Boy's, Children's.” Late Victorian Era Fashion Facts: Women's, Men's, Girl's, Boy's, Children's, http://victorianera.org/late-victorian-fashion-women-men-girls-boys.html.

\section{Research Image 24}

Sunflower Siblings- 1800s Antique Photograph- Victorian Children- Manitowoc, WisconsinCDV Portrait- Photographer Hugo Klingholz.” Ephemera Obscura Collection, Shopify, 2019, https://ephemeraobscura.com/products/sunflower- siblings-1800s-antiquephotograph-victorian-children-manitowoc-wisconsin-carte-de- visite-cdv-portrait-paperephemera.

\section{Research Image 25}

Connolly, Sybil. “Boy's Jacket and Vest, 1870-1874.” FIDM Museum Blog, 2010, https:// blog.fidmmuseum.org/museum/2010/06/boys-jacket-and-vest-18701874.html\#more.

\section{Research Image 26}

An Extensive Study of the Victorian Era: Step Back into an Age of Paradox and Power; The Victorian Age Was Not One, Not Single, or Simple. The Victorian Era, 1997, http:// Www.avictorian.com/servants_nursery.html. 


\section{Research Image 27}

"Biography." Arthur Conan Doyle, The Sir Arthur Conan Doyle Literary Estate, 2000, https://www.arthurconandoyle.com/biography.html.

\section{Research Image 28}

“Vintage Photos." LoveVintageDolls, 2019, http://lovevintagedolls.aloarquitectura.com/ vintage.

\section{Research Image 29}

Cook, Walter. "Bustles, Bodices and Broad-Brimmed Hats." National Library of New Zealand Te Puna Mātauranga o Aotearoa, New Zealand Government, 2014, https:// natlib.govt.nz/blog/posts/bustles-bodices-and-broad-brimmed-hats.

\section{Research Image 30}

"Digital Collections: Portrait of a Woman." Free Library of Philadelphia, https:// libwww.freelibrary.org/digital/item/22803. 


\section{Research Image 31}

Museum, Albert, and Digital Media. "History of Fashion 1840 - 1900." History of Fashion 1840 - 1900, Victoria and Albert Museum, Cromwell Road, South Kensington, London SW7 2RL. Telephone 44 (0)20 7942 2000. Email Vanda@Vam.ac.uk, 11 July 2013, http://www.vam.ac.uk/content/articles/h/history-of-fashion-1840-1900/.

Research Image 32

“LOT 217 COTTON DRESS with STRAWBERRY PRINT, 1863.” Whitakerauction, Smug Mug Inc. , 2019, https://whitakerauction.smugmug.com/The-Helen-LarsonPrivate-Collection/1870s-through-1890s/LOT-217-COTTON-DRESS-withSTRAWBERRY-PRINT-1863/.

\section{Research Image 33}

An Extensive Study of the Victorian Era: Step Back into an Age of Paradox and Power; The Victorian Age Was Not One, Not Single, or Simple. The Victorian Era, 1997, http:// www.avictorian.com/servants_nursery.html.

\section{Research Image 34}

Oakes, Leimomi. “The HSM 2016: Challenge \#3: Protection.” The Dreamstress, 17 Feb. 2016, http://thedreamstress.com/2016/02/the-hsm-2016-challenge-3-protection/. 


\section{Research Image 35}

Gross, Kali Nicole. “Ordinary Yet Infamous: Hannah Mary Tabbs and the Disembodied Torso.” Not Even Past, 1 Feb. 2016, https://notevenpast.org/ordinary-yet-infamous- hannahmary-tabbs-and-the-disembodied-torso/.

\section{Research Image 36}

LovedayLemon. "At the Seaside with the Nursemaid.” Flickr, Yahoo!, 5 Sept. 2008, https://www.flickr.com/photos/lovedaylemon/2830619817/.

\section{Research Image 37}

Clayton." The United Organization Toons Heroes Wiki, https:// theunitedorganizationtoonsheroes.fandom.com/wiki/Clayton

\section{Research Image 38}

Rose, Steve. "From Tarzan to Avatar: the Problem with 'the White Man in the Jungle'." The Guardian, Guardian News and Media, 6 July 2016, https:// www.theguardian.com/film/2016/jul/06/why-the-white-man-in-the-jungle-film-wont-die

\section{Research Image 39}

“Henry Morton Stanley Books.” Shakari Connection, 2008, https://

www.shakariconnection.com/henry-morton-stanley-books.html. 


\section{Research Image 40}

Leather, Blaze. “Home.” Blaze Leather, https://www.blaze-leather.com/mens-leathermotorcycle-vest.html.

\section{Research Image 41}

Holt, James A. "A Study of the British Officer on Active Service in South Africa 1899 - 1902." Military Sun Helmets, Word Press, 5 May 2012, http:// www.militarysunhelmets.com/2012/a-study-of-the-british-soldier-on-active-service-insouth-africa-1899-1902.

\section{Research Image 42}

Holt, James A. "A Study of the British Officer on Active Service in South Africa 1899 - 1902." Military Sun Helmets, Word Press, 5 May 2012, http:// www.militarysunhelmets.com/2012/a-study-of-the-british-soldier-on-active-service-insouth-africa-1899-1902.

\section{Research Image 43}

“Dressed in Time.” Dressed in Time, Blogger, http://dressedintime.blogspot.com/

$2012 / 11 /$. 


\section{Research Image 44}

Sharif, Al, and Raad Al Anbaky. "The Real American Heiresses Who Saved the British Aristocracy - Mary Leiter, Baroness Curzon.” The Crown Chronicles, London Reign Communications Ltd, 1 Aug. 2016, https://thecrownchronicles.co.uk/history/historyposts/american-heiresses-saved-british-aristocracy-mary-leiter-baroness-curzon/.

\section{Research Image 45}

The Editors of Encyclopaedia Britannica. "Ina Donna Coolbrith.” Encyclopcedia Britannica, Encyclopædia Britannica, Inc., 6 Mar. 2019, https://www.britannica.com/ biography/InaDonna-Coolbrith.

\section{Research Image 46}

Accidental Half-Pint.” Chictopia, 16 Dec. 2010, http://www.chictopia.com/photo/show/ 374250Accidental Half Pint-black-maxi-httpstoresebaycomtwitchvintage-skirt-black- lace-upforever-21-boots.

\section{Research Image 47}

Brain, Denise. "VINTAGE DENISEBRAIN." Denisebrain Vintage, 4 May 2017, https://

www.denisebrain.com/vintage-denisebrain/?offset=1494527643161. 


\section{Research Image 48}

McGerr, Fleur. "Dressing down, Vintage Style.” Words by Fleur, 3 Mar. 2011, https:// www.wordsbyfleur.com/2011/03/dressing-down-vintage-style/.

\section{Research Image 49}

"What to Wear: a Floral Skirt.” My Power Pose, Hello Brio, 28 July 2015, http://

mypowerpose.com/what-to-wear-floral-skirt/

\section{Research Image 50}

Vogue Japan. “THE VALUE OF STYLE.” VOGUE JAPAN, Vogue Japan, 21 July 2019, https://www.vogue.co.jp/fashion/fashionstories/theme/13.

\section{Research Image 51}

Tibisay. "Artherapy.” Artherapy, Blogspot, 1 Jan. 2013, http://tibisayartherapy.blogspot.com/2013/09/.

\section{Research Image 52}

Moneta, Caitlan. "Bright Monochromatic Suits for Everyone! | CBC Life." CBCnews, CBC/Radio Canada, 4 July 2018, https://www.cbc.ca/life/style/bright-monochromaticsuits-for-everyone-1.4733677.

\section{Research Image 53}


admin_moda. “Модные Цвета Одежда 2018.” Мup Modbl, 24 Mar. 2017, http://modamir.ru/modnye-cveta-odezhda-2018/.

\section{Research Image 54}

"Women Pants Suit, High Waist Women Suit, Yellow." LeStyleParfait.Com, https:// www.lestyleparfait.com/products/women-pants-suit-high-waist-women-suit-yellow.

\section{Research Image 55}

Livingston, Justin. “Justin Livingston on Instagram: 'Festival Day Two Look."' Instagram, Instagram, 15 Apr. 2017, https://www.instagram.com/p/BS7Glh_Dhvo/.

\section{Research Image 56}

Bailey, Christopher. "Burberry Prorsum Fall-Winter 2014 Men's Collection.” GQ, Conde Nast, 20 June 2015, https://www.gq.com/gallery/burberry-prorsum-fall-winter-2014.

\section{Research Image 57}

Kirkpatrick, Emily. “Jeff Goldblum Is a Fashion Icon.” Page Six, Word Press, 18 Oct. 2018, https://pagesix.com/2018/10/18/jeff-goldblum-is-a-fashion-icon/.

\section{Research Image 58}


“Westknits.” Deep South Fibers, 2019, https://www.deepsouthfibers.com/brands/

Westknits.html.

\section{Research Image 59}

"Westknits." A Yarn Story, Shopify, 2007, https://ayarnstory.co.uk/collections/westknits.

Research Image 60

“Lia \& Odette Pavlova Star in Vogue Russia November 2016 Cover Story.” Design Scene, Design SCENE Magazine, 25 Oct. 2016, https://www.designscene.net/2016/10/ liaodette-pavlova-vogue-russia.html.

\section{Research Image 61}

"Burberry Trench Coat Mens Pink." Burberry Trench Coat Mens Pink, Burberry Clothing \& Shoes - Up to 90\% off Discount Sale, 2015, http://www.storeburberry.top/burberrytrench-coat-mens-pink-TT218826.html.

\section{Research Image 62}

“Genie Pants for Burning Man - CLOTHING." A Crafts Community For Craft Ideas \& DIY Projects - Craftster.org, Craftster, 28 Sept. 2012, https://www.craftster.org/forum/ index.php?topic $=414858.0$.

\section{Research Image 63}


“Sacred Geometry Infinity Scarf.” Stardust Love, Shopify, 2019, https://

www.stardustlove.com/products/sacred-geometry-disco.

\section{Research Image 64}

Admin, WEKOKO. "Burning Man.” WEKOKO Blog, 10 Mar. 2016, http://

www.wekoko.com/blog/tag/burning-man/.

\section{Research Image 65}

“Stylish Sexy Lace Embroidered Mesh Maxi Dress With Underskirt.” Ezpopsy, 2018, https://www.ezpopsy.com/Products/stylish-sexy-lace-embroidered-mesh-maxi-dresswith-underskirt-52550.html.

\section{Research Image 66}

"Maxi Dress." Poshmark, https://poshmark.com/listing/Maxi- Dress$5 \mathrm{~d} 1 \mathrm{c} 043929 \mathrm{f} 030 \mathrm{c} 54 \mathrm{f} 44 \mathrm{c} 12 \mathrm{~d}$.

\section{Research Image 67}

"Button Down Collar Stripes Roll Up Sleeve Half Sleeve Maxi Dresses." Cicilookshop, https://www.cicilookshop.com/button-down-collar-stripes-roll-up-sleeve-half-sleevemaxi-dresses-p-37441.html

\section{Research Image 68}


“Cibeles MFW: Juanjo Oliva.” La Ratita Presumida, 23 Sept. 2009, http://

www.ratitapresumida.com/2009/09/21/cibeles-mfw-juanjo-oliva/.

\section{Research Image 69}

“Topshop Skinny Rib Crop Tee.” Celebrity Fashionista, 30 May 2015, https://

celebrityfashionista.com/taylor-swift/topshop-skinny-rib-crop-tee/.

\section{Research Image 70}

Olesinska, Milena. “Art \& Fashion - Versace Women's Spring Summer 2018.” Exposition Art Blog, https://milenaolesinska.blogspot.com/2018/02/art-fashion-versace-womensspring.html.

\section{Research Image 71}

De Moda, Marcus. “El Mundo Estampado De Discount Universe.” Viste La Calle, 17

Apr. 2014, http://vistelacalle.com/108139/el-mundo-estampado-de-discount-universe/.

Research Image 72 
Wasilak, Sarah. "All the Coachella Style You Have to See From Last Year's Festival.” POPSUGAR Fashion, 14 Apr. 2016, https:/www.popsugar.com/fashion/photogallery/37244855/image/37260860/Danielle-Bernstein-wore-black-bodysuit-beneath-herbreezy-Love.

\section{Research Image 73}

Burritt, Britt. “Get the Look: Festival Style at Coachella 2017.” Festival Style at Coachella 2017 | Nordstrom Fashion Blog, 9 Nov. 2017, https://blogs.nordstrom.com/ fashion/get-thelook-festival-style-at-coachella-2017/.

\section{Research Image 74}

“Turquoise Holographic Romper.” Coquetry Clothing, https://coquetryclothing.com/ products/turquoise-holographic-romper.

\section{Research Image 75}

Muller, Marissa G. "Miley Cyrus' Furry Birthday Jacket Has Fashion History.” MTV News, 24 Nov. 2014, http://www.mtv.com/news/2007811/miley-cyrus-birthday-outfit/.

\section{Research Image 76}


“Lia \& Odette Pavlova Star in Vogue Russia November 2016 Cover Story.” Design Scene, Design SCENE Magazine, 25 Oct. 2016, https://www.designscene.net/2016/10/ liaodette-pavlova-vogue-russia.html.

\section{Research Image 77}

Freyr. "PRINTS LOOK SO SEXY ON MEN Pic.twitter.com/EvtJqKgQIw.” Twitter, Twitter, 21 Oct. 2017, https://twitter.com/sunfloweraidil/status/921756829880741888.

\section{Research Image 78}

We Heart It | Get lost in what you love. "Harry Styles Shared by ItsEm on We Heart It." We Heart It, 27 Sept. 2019, https://weheartit.com/entry/66666759.

\section{Research Image 79}

Dadds, Kimberley. “37 Times Benedict Cumberbatch Well And Truly Owned 2014.” BuzzFeed, BuzzFeed, 3 Oct. 2018, https://www.buzzfeed.com/kimberleydadds/ 214-got-cumberbatched.

\section{Research Image 80}

“Trinity Collective Men's Striped 7.5' Shark Patterned Elastic Waist Board Shorts - Teal.” Target, https://www.target.com/p/trinity-collective-men-s-striped-7-5-shark- patternedelastic-waist-board-shorts-teal/-/A-53697865.

\section{Research Image 81}


“Male Fashion Models.” Bellazon, 17 July 2008, https:/www.bellazon.com/main/topic/ 16625-marlon-teixeira/page/304/.

\section{Research Image 82}

"NOTES from the BURN- Part II." Twenty Five Hundred, 14 Feb. 2017, http:// twentyfivehundred.com/radical-self-expression-at-burning-man-costumes-to-be-inspiredby/.

\section{Research Image 83}

Peng, Matt. "Syndicate Original's 2018 Spring/Summer Collection Is a 'DDDream.'” HYPEBEAST, HYPEBEAST, 29 June 2017, https://hypebeast.com/2017/6/ syndicate-original-2018-spring-summer-collection.

\section{Research Image 84}

“All I Do Is Fuck And Party.” DailyPicdump, https://dailypicdump.com/all-i-do-is-fuck- andparty.

\section{Research Image 85}

SpiritHoods. "Foxes*." SpiritHoods, Shopify, https://www.spirithoods.com/collections/ foxes 2 .

Research Image 86 
"Mens OppoSuits Slim-Fit Tropicool Suit \& Tie Set.” Kohls, https://www.kohls.com/ product/prd-3313702/mens-opposuits-slim-fit-tropicool-suit-tie-set.jsp?prdPV=5.

\section{Research Image 87}

“Koi Fish by Samuelyounart on DeviantArt." By Samuelyounart on DeviantArt, https:// www.deviantart.com/samuelyounart/art/Koi-Fish-750100470.

\section{Research Image 88}

Everything Is Political When You Are a Woman. https://i.pinimg.com/originals/a3/0e/22/ a30e2232a1 fb4bb6e9e7edeacfcc1bb4.jpg.

\section{Research Image 89}

Queeringstyle. "Queeringstyle.” Queering Style, 30 July 2015, https://

queeringstyle.tumblr.com/post/125384113208.

\section{Research Image 90}

“Notorious RBG Womens T-Shirt.” Guerrilla Graphix, https:/guerillagraphix.com/ collections/t-shirts-womens/products/notorious-rbg-womens-t-shirt.

\section{Research Image 91}


Webster, Vanessa. "The Fam.” Stillsane, https://stillsaneclothing.com/pages/the-fam.

\section{Research Image 92}

Short Hair Cut. https://i.pinimg.com/originals/62/d0/4e/

$$
\text { 62d04eda853ce43ddf69e66c0357ae3d.jpg }
$$

\section{Research Image 93}

“Style Thief: How to Dress Like Ellen Page." Autostraddle, The Excitant Group, 25 Aug.

2013, https:/www.autostraddle.com/style-thief-how-to-dress-like-ellen-page-153178/.

\section{Research Image 94}

Olins , Josh. “Miss Vogue - Milou Van Groesen by Josh Olins.” TAMMY DE FOX, 5 Apr. 2013, https://tammydefox.wordpress.com/2012/07/23/miss-vogue-milou-van-groesen-by- josholins/.

\section{Research Image 95}

"Slay for a Change Brings the Black Lives Matter Movement to New York Fashion Week." Fashion Bomb Daily Style Magazine: Celebrity Fashion, Fashion News, What To Wear, Runway Show Reviews, 7 Mar. 2017, http://fashionbombdaily.com/slay-for-a- changebrings-the-black-lives-matter-movement-to-new-york-fashion-week/.

\section{Research Image 96}


Yandoli, Krystie Lee. "The Powerful T-Shirt One Woman Wore To New York Fashion Week." BuzzFeed, BuzzFeed, 11 Sept. 2014, https://www.buzzfeed.com/krystieyandoli/ thepowerful-t-shirt-one-woman-wore-to-new-york-fashion-week.

\section{Research Image 97}

Feshchuk, Inna. “Ankara Styles For Skinny Ladies.” Jiji Blog, 14 July 2018, https://jijiblog.com/2018/07/ankara-styles-skinny-ladies/.

\section{Research Image 98}

“Shop Equality Matters T-Shirts Online.” Spreadshirt, https://www.spreadshirt.com/men equality matters t-shirts.

\section{Research Image 99}

“Ruly, a Place for Black Hair and Women.” Un-Ruly, Cassius Network, https://unruly.com/.

\section{Research Image 100}

"How to Wear Platform Shoes.” Glam Radar, http://glamradar.com/how-to-wearplatform-shoes/. 
Y-626 Xena - Women's Fetish Gothic Style Synthetic Leather Jacket." Fantasmagoria.shop - Retail \& Wholesale Gothic Clothes and Accessories, https://www.fantasmagoria.eu/y-626-xena-jacket-punk-rave.

\section{Research Image 102}

“Street Style City's Photos Tagged with Pvc." Flickriver, https://www.flickriver.com/ photos/bobsphotographynl/tags/pvc/.

\section{Research Image 103}

Moon Goth. https://I.pinimg.com/Originals/8b/ 73/57/8b73579102417a6dd2cbbfa8abb53912.Jpg, 2019.

\section{Research Image 104}

lookbook.nu/sarasilva LB: sara7silva IG: www.eighteenandalife.com Blog: http:/https:// www.facebook.com/blog.eighteenandalife Site: "SARA SILVA.” Lookbook, https:// lookbook.nu/user/105161-SARA-S/looks/hyped.

\section{Research Image 105}

Chết Mê Với Nhũng Siêu Mẫu Nhí Cực Cute. Blog Làm Cha, 2019, http:// bloglamcha.com/chet-me-voi-nhung-sieu-mau-nhi-cuc-cute.html. 
“The Hair Bow Factory Over the Top Lollipop Candy Tutu Dress Size 12-24 Months to Size 6." Etsy, https://www.etsy.com/sg-en/listing/157657004/the-hair-bow-factory-over- the-top.

\section{Research Image 107}

“'Men Wearing Their Girlfriends' Clothes' Is My New Favorite Thing.” DangerousMinds, 11 May 2015, https://dangerousminds.net/comments/ men_wearing_their_girlfriends_clothes_is_my_new_favorite_thing.

\section{Research Image 108}

“Girls Dresses Cotton Casual Children Clothing Autumn Spring Baby Girl Dress Long Sleeve Girls Party Dresses Big Kids Clothes.” Bajby.com, https://bajby.com/products/ 9611572.

\section{Research Image 109}

“Always Wondered Why They Behave Like A Child? They May Be Suffering From Little Prince Syndrome.” Storypedia, http://www.thestorypedia.com/lifestyle/alwayswondered- why-they-behave-like-a-child-they-may-be-suffering-from-little-princesyndrome/.

\section{Research Image 110}

“2019 Grils Sequined Modern Jazz Hip Hop Dance Wear Hoodie Outfits Blue Kids Dancing Costumes 110160 From Yuanchun, \$27.97.” DHgate, https://www.dhgate.com/ product/grils-sequined-modern-jazz-hip-hop-dance/431114030.html\#seo=WAP.

\section{Research Image 111}


Morris Costume. Amazon, https://www.amazon.com/Morris-Costumes-Tutu-GrandeWhite/dp/B004102FSU/ref=sr_1_1?dchild=1\&keywords=adult man tutu\&qid=1575521119\&sr=8-1.

\section{Research Image 112}

Tolleythompson. "How to Raise Children and Pets II." Clear Mirror Healing, 1 June 2015, https://clearmirrorhealing.wordpress.com/2015/06/01/how-to-raise-children-andpets-ii/.

\section{Research Image 113}

“\$510, Fratelli Borgioli Handmade Brown Italian Leather Wingtip Oxford Shoes.” Lookastic, https://lookastic.com/men/tan-leather-oxford-shoes/shop/handmadebrown-italian-leather-wingtip-oxford-shoes-2830.

\section{Research Image 114}

"How to Wear a Dark Green Plaid Long Sleeve Shirt For Men." How to Wear a Dark Green Plaid Long Sleeve Shirt For Men (15 Looks \& Outfits) | Mens Fashion | Lookastic.com, https://lookastic.com/men/dark-green-plaid-long-sleeve-shirt/looks. 
Mensfashionworld. "Mensfashionworld.” Men's Fashion \& Style, 26 Dec. 2012, https://

mensfashionworld.tumblr.com/post/38824509491.

\section{Research Image 116}

Brewer, Taylah. "How to Wear a Pink Shirt with Style." The Trend Spotter, 30 July 2019, https://www.thetrendspotter.net/how-to-wear-a-pink-shirt/.

\section{Research Image 117}

Singer, Maya. "Devon Halfnight LeFlufy Fall 2015 Menswear Fashion Show.” Vogue, Vogue, 8 Aug. 2015, https://www.vogue.com/fashion-shows/fall-2015-menswear/devon- halfnightleflufy/slideshow/collection.

\section{Research Image 118}

Jr, Robert Marshall. "Dior Homme Continues to Reinvent the Black Suit for 2017 Fall/ Winter." HYPEBEAST, HYPEBEAST, 21 Jan. 2017, https://hypebeast.com/2017/1/dior- homme2017-fall-winter-collection-paris-fashion-week.

\section{Research Image 119}

Petty, Felix. "Take an Exclusive First Look at Gosha's New Sunglasses Collection.” I, 15 Feb. 2018, https://i-d.vice.com/en_uk/article/j5bg7d/take-an-exclusive-first-look-at- goshasnew-sunglasses-collection.

Research Image 120 
“Jean Paul Gaultier." Jean Paul Gaultier, http://hautevoltage2.blogspot.com/2011/01/

jean-paul-gaultier.html.

\section{Research Image 121}

“Morgantown WV under Streetlight.” West Virginia Explorer, 4 Dec. 2019, https://

wvexplorer.com/2019/08/31/paranormal-expo-cheat-lake-wv-west-virginia/morgantownwv-under-streetlight/.

Research Image 122

“Arme Chimique En Irak.” - Blog, https://felixducharme.weebly.com/blog/ october-15th-2014.

\section{Research Image 123}

Rakshasa. "Captain America Video: How Captain America Was Able To Use Thor's Hammer In Avengers: Endgame." Fanpop, http://www.fanpop.com/clubs/captainamerica/videos/42826335/title/how-captain-america-able-use-thors-hammer-avengersendgame. 


\section{Appendix D: "Scene Breakdown"}

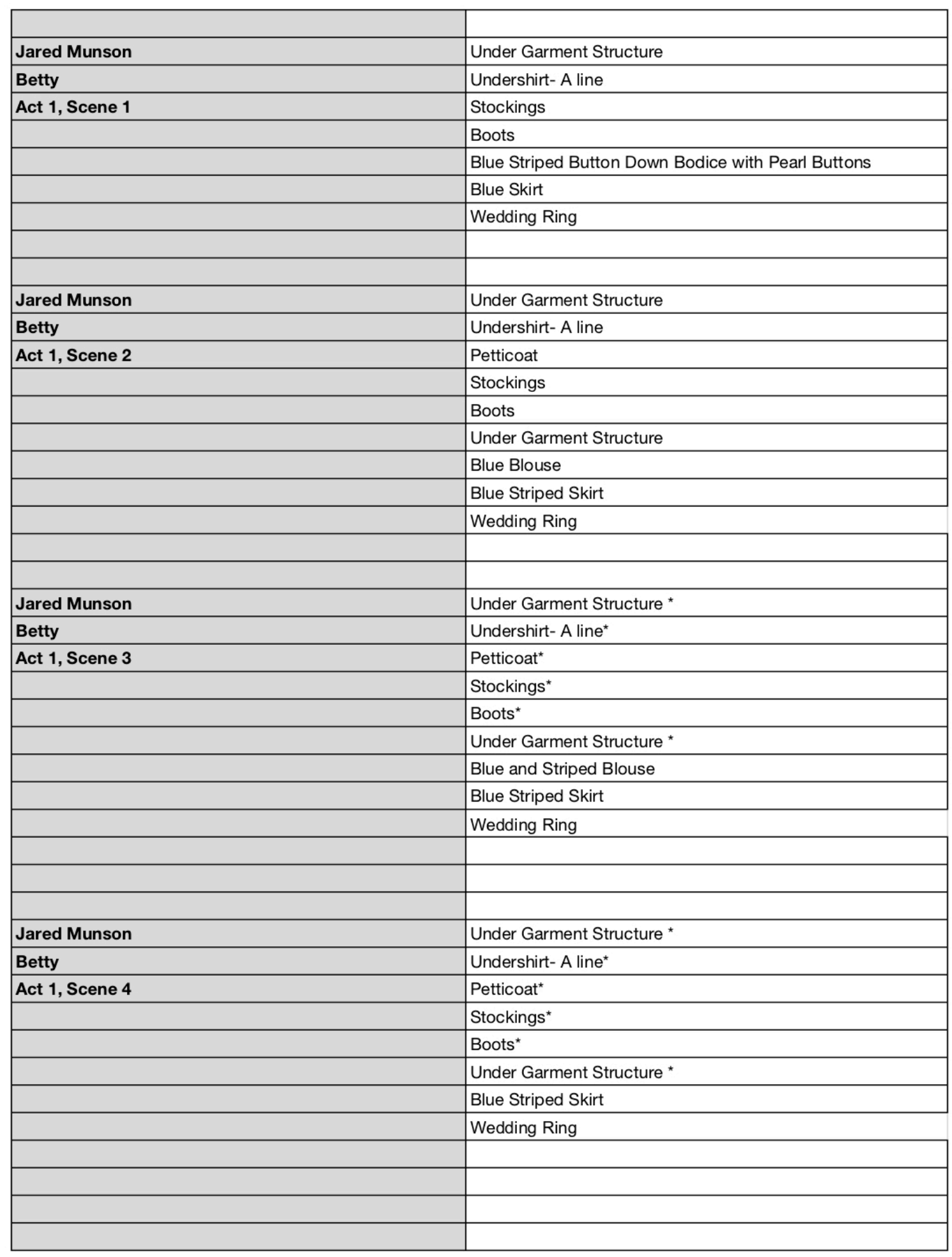




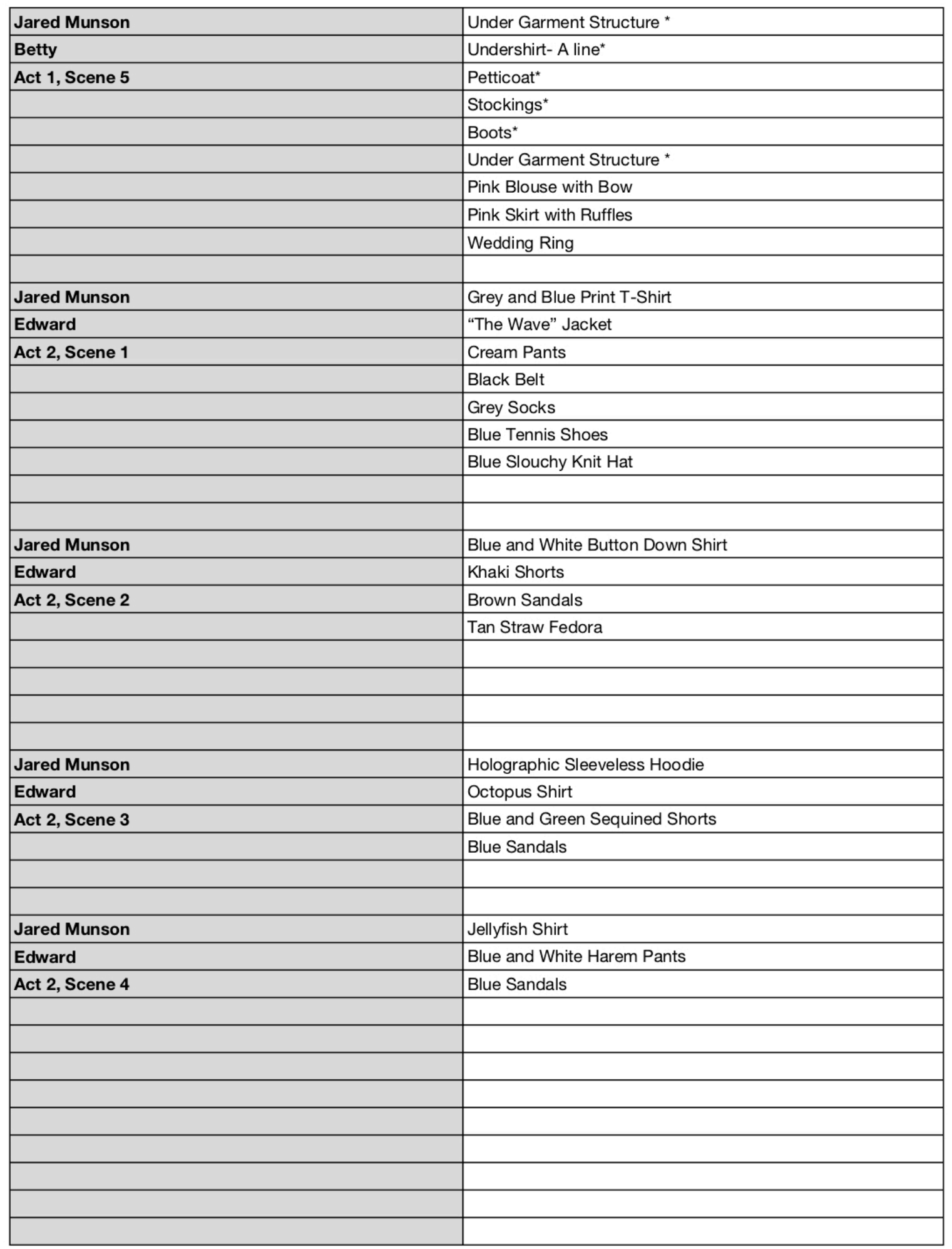




\begin{tabular}{|c|c|}
\hline Matt Clark & Undershirt- T shirt \\
\hline Clive & Button Down Off White Shirt \\
\hline \multirow[t]{9}{*}{ Act 1, Scene 1} & Tan Button Down Jacket \\
\hline & Brown Double Breasted Vest \\
\hline & Tan Pants \\
\hline & Brown Suspenders \\
\hline & Tall Black Boots \\
\hline & Brown Belt with Pouches \\
\hline & Brown Neck Tie \\
\hline & Tan Explorer Hat \\
\hline & Pocket Square \\
\hline Matt Clark & Undershirt- T shirt \\
\hline Clive & Button Down Off White Shirt \\
\hline \multirow[t]{5}{*}{ Act 1, Scene 2} & Brown Double Breasted Vest \\
\hline & Tan Pants \\
\hline & Brown Suspenders \\
\hline & Tall Black Boots \\
\hline & Brown Neck Tie \\
\hline Matt Clark & Undershirt- T shirt \\
\hline Clive & Button Down Off White Shirt \\
\hline \multirow[t]{4}{*}{ Act 1, Scene 3} & Tan Pants \\
\hline & Brown Suspenders \\
\hline & Tall Black Boots \\
\hline & Brown Neck Tie \\
\hline Matt Clark & Undershirt- T shirt \\
\hline Clive & Button Down Off White Shirt \\
\hline \multirow[t]{9}{*}{ Act 1 , Scene 4} & Tan Button Down Jacket \\
\hline & Brown Double Breasted Vest \\
\hline & Tan Pants \\
\hline & Brown Suspenders \\
\hline & Tall Black Boots \\
\hline & Brown Belt with Pouches \\
\hline & Brown Neck Tie \\
\hline & Tan Explorer Hat \\
\hline & Pocket Square \\
\hline & \\
\hline & \\
\hline
\end{tabular}




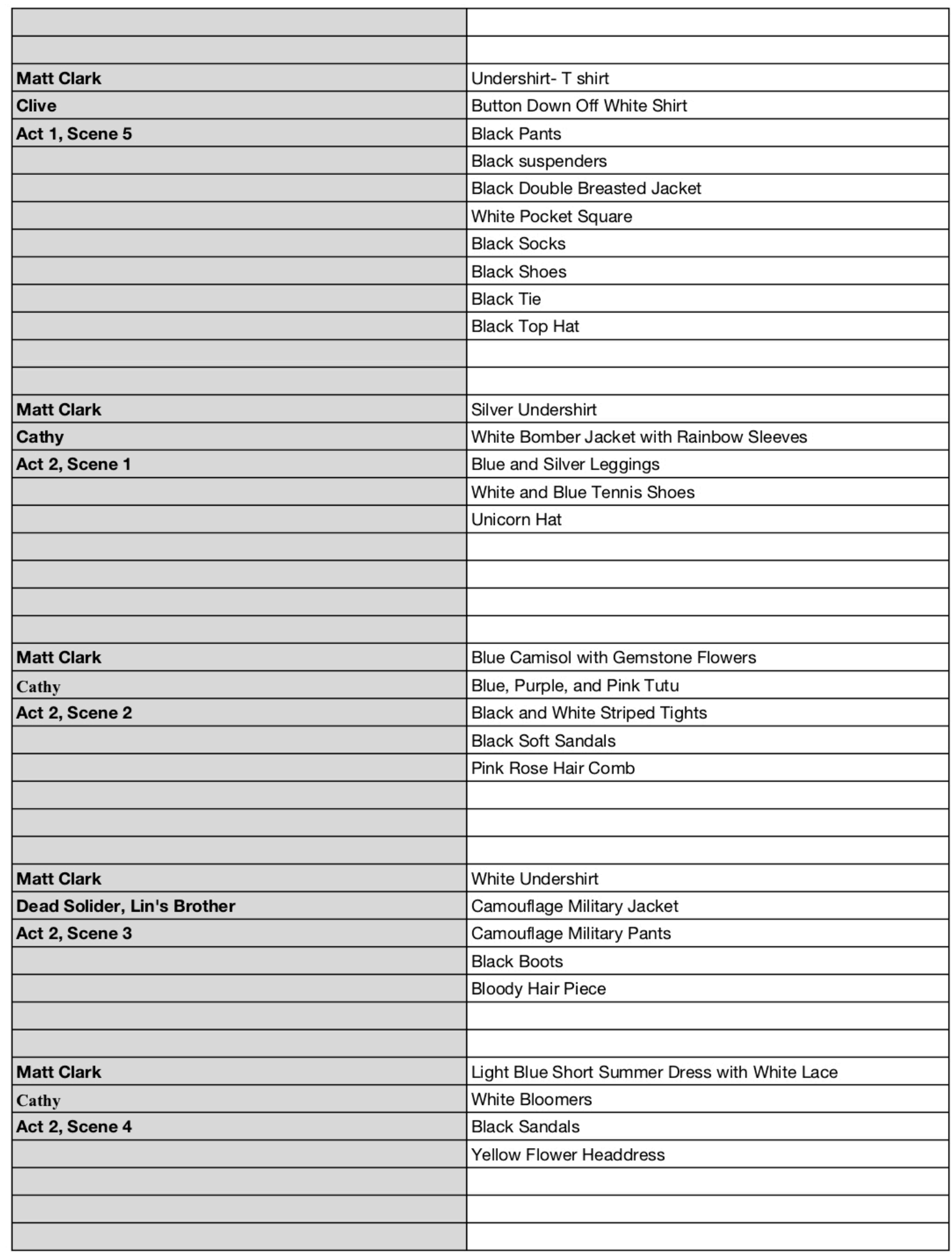




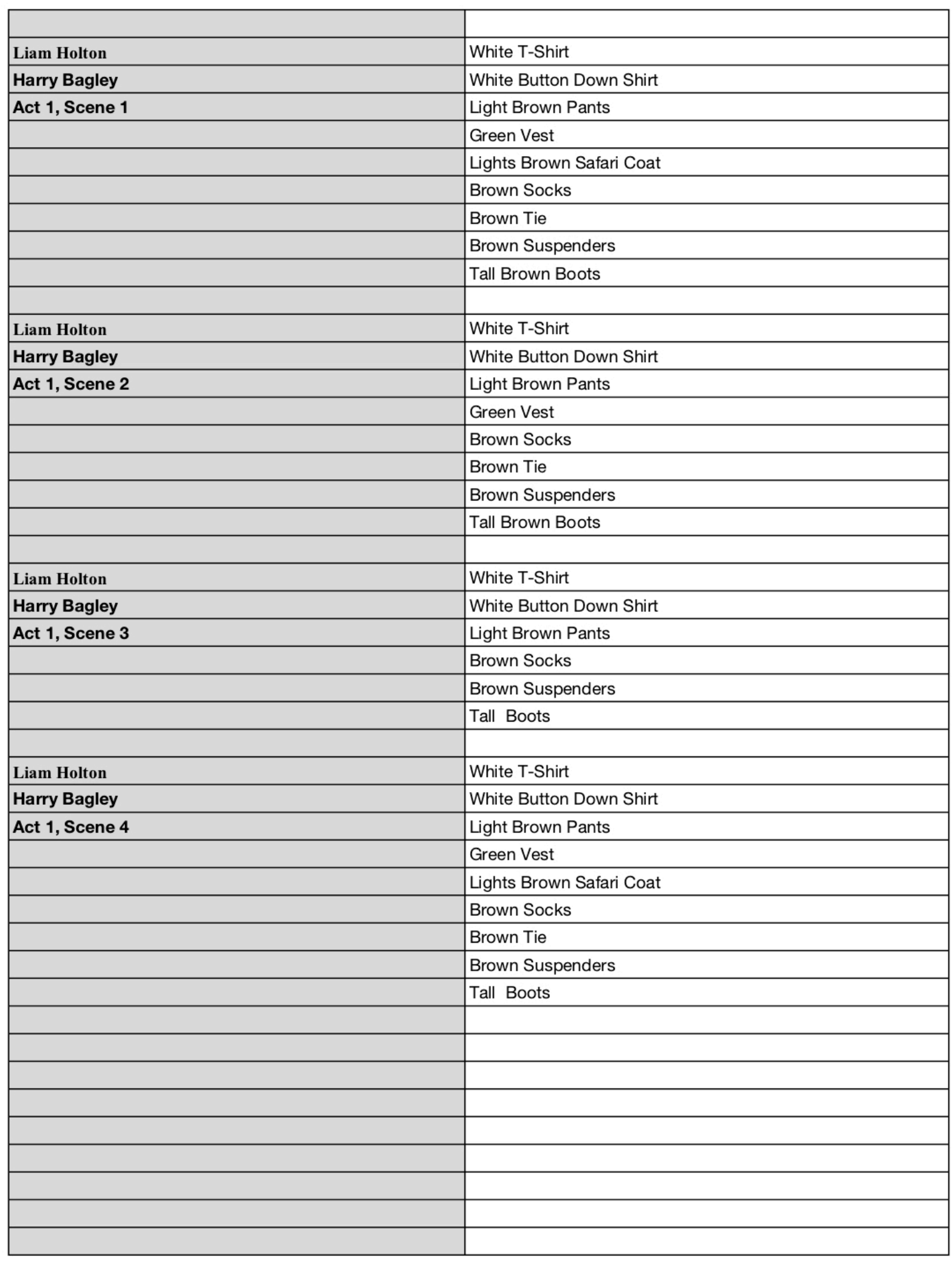




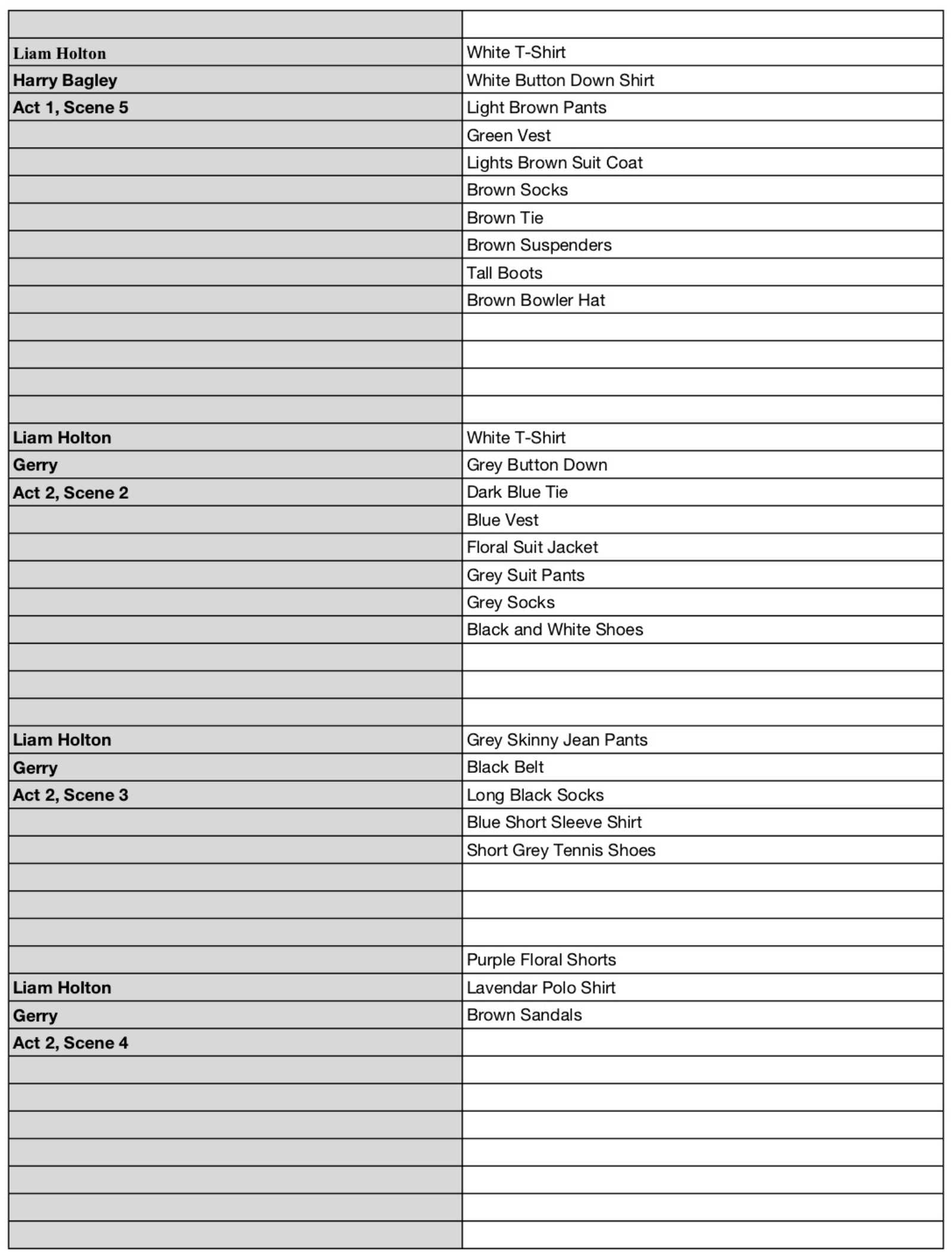




\begin{tabular}{|c|c|}
\hline Haley Hizer & White T-Shirt \\
\hline Edward & White Button Down Shirt \\
\hline \multirow[t]{7}{*}{ Act 1, Scene 1} & Black Short Pants \\
\hline & Black Socks \\
\hline & Gray Suspenders \\
\hline & Short Black Shoes \\
\hline & Neck Tie Bow \\
\hline & Grey Vest \\
\hline & Black Suit Jacket \\
\hline Haley Hizer & White T-Shirt \\
\hline Edward & White Button Down Shirt \\
\hline \multirow[t]{6}{*}{ Act 1, Scene 2} & Black Short Pants \\
\hline & Black Socks \\
\hline & Gray Suspenders \\
\hline & Short Black Shoes \\
\hline & Neck Tie Bow \\
\hline & Grey Vest \\
\hline Haley Hizer & White T-Shirt \\
\hline Edward & White Button Down Shirt \\
\hline \multirow[t]{4}{*}{ Act 1, Scene 3} & Black Short Pants \\
\hline & Black Socks \\
\hline & Gray Suspenders \\
\hline & Short Black Shoes \\
\hline Haley Hizer & White T-Shirt \\
\hline Edward & White Button Down Shirt \\
\hline \multirow[t]{5}{*}{ Act 1, Scene 4} & Black Short Pants \\
\hline & Black Socks \\
\hline & Gray Suspenders \\
\hline & Short Black Shoes \\
\hline & Grey Vest \\
\hline Haley Hizer & White T-Shirt \\
\hline Edward & White Button Down Shirt \\
\hline \multirow[t]{6}{*}{ Act 1, Scene 5} & Black Short Pants \\
\hline & Black Socks \\
\hline & Gray Suspenders \\
\hline & Short Black Shoes \\
\hline & Neck Tie Bow \\
\hline & Black Vest with Nice Lapels \\
\hline
\end{tabular}




\begin{tabular}{|c|c|}
\hline Ryan Ernst & T Shirt* \\
\hline Joshua & White and Brown Striped Button Down Shirt \\
\hline \multirow[t]{6}{*}{ Act 1, Scene 1-4 } & Neck Tie \\
\hline & Brown Vest \\
\hline & Black Loose Pants \\
\hline & Olive Suit Coat \\
\hline & Black Socks \\
\hline & Black Shoes \\
\hline Ryan Ernst & T Shirt* \\
\hline Joshua & White and Brown Striped Button Down Shirt \\
\hline \multirow[t]{6}{*}{ Act 1 , Scene 5} & Black Neck Tie* \\
\hline & Brown Vest* \\
\hline & Black Loose Pants* \\
\hline & Black Double Breasted Suit Coat \\
\hline & Black Socks $^{\star}$ \\
\hline & Black Shoes* \\
\hline Ryan Ernst & Seafoam Polo Shirt \\
\hline \multirow[t]{2}{*}{ Martin } & Black Pants \\
\hline & Black Socks* \\
\hline \multirow[t]{4}{*}{ Act 2 Scene 2} & Black and White Shoes \\
\hline & Tattoo Sleeve \\
\hline & Watch \\
\hline & Glasses \\
\hline Ryan Ernst & Fitted Dark Grey Shirt \\
\hline Martin & Khaki Shorts \\
\hline \multirow[t]{5}{*}{ Act 2 Scene 3} & Black Socks* \\
\hline & Black and White Shoes \\
\hline & Tattoo Sleeve \\
\hline & Watch \\
\hline & Glasses \\
\hline Ryan Ernst & This is what a feminist looks like Grey t-shirt \\
\hline Martin & Blue Shorts \\
\hline \multirow[t]{4}{*}{ Act 2 Scene 4} & Sandals \\
\hline & Tattoo Sleeve \\
\hline & Watch \\
\hline & Glasses \\
\hline
\end{tabular}




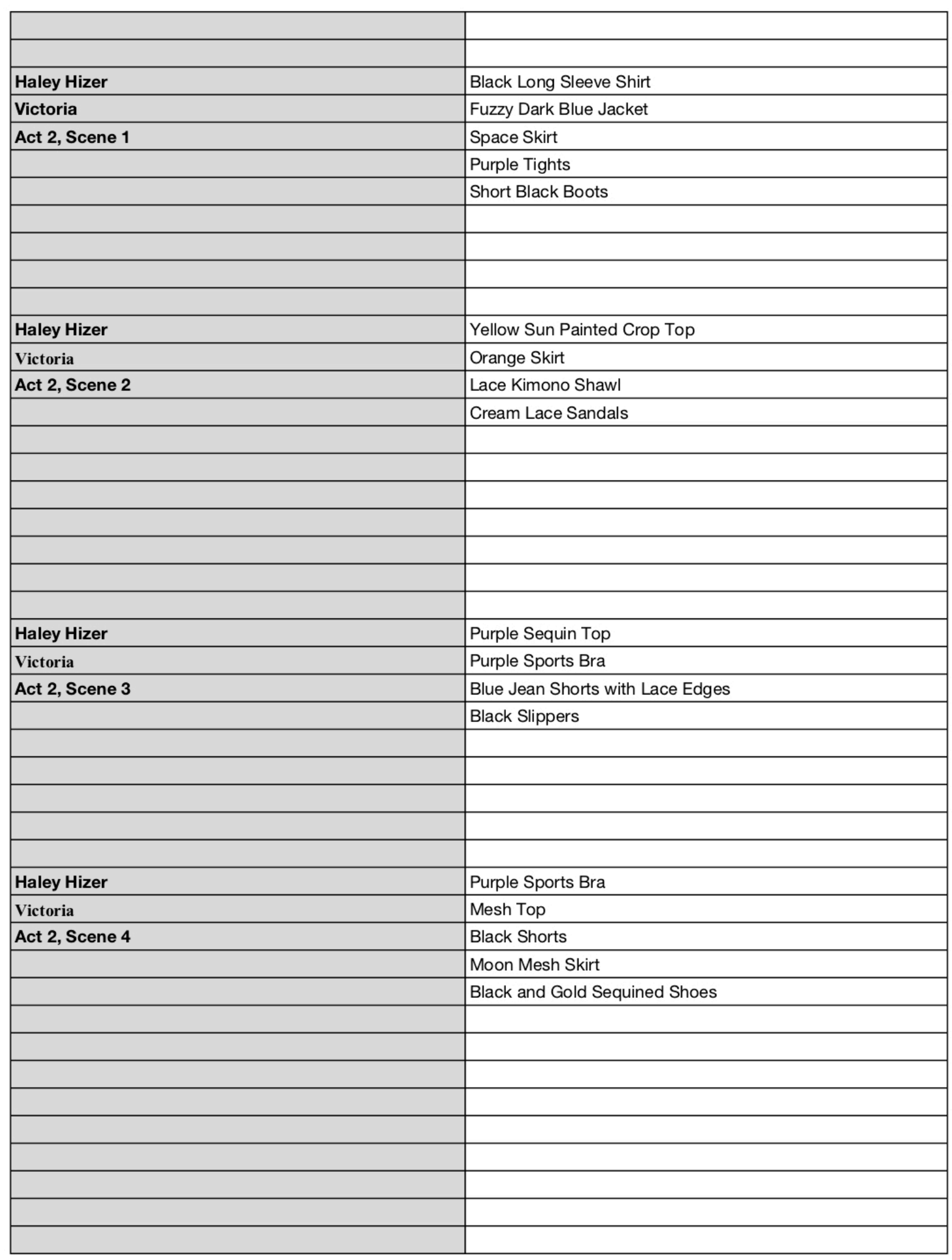




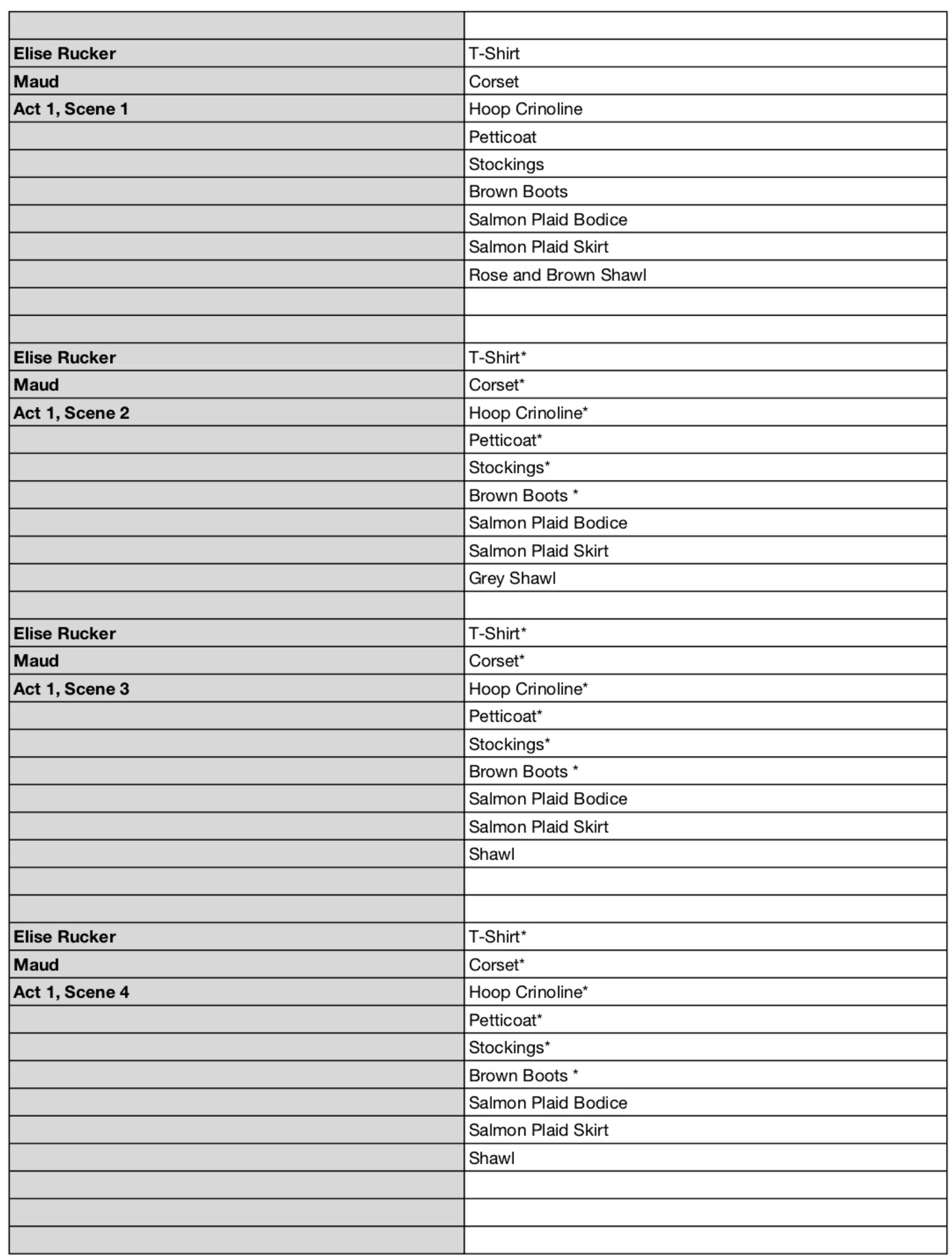




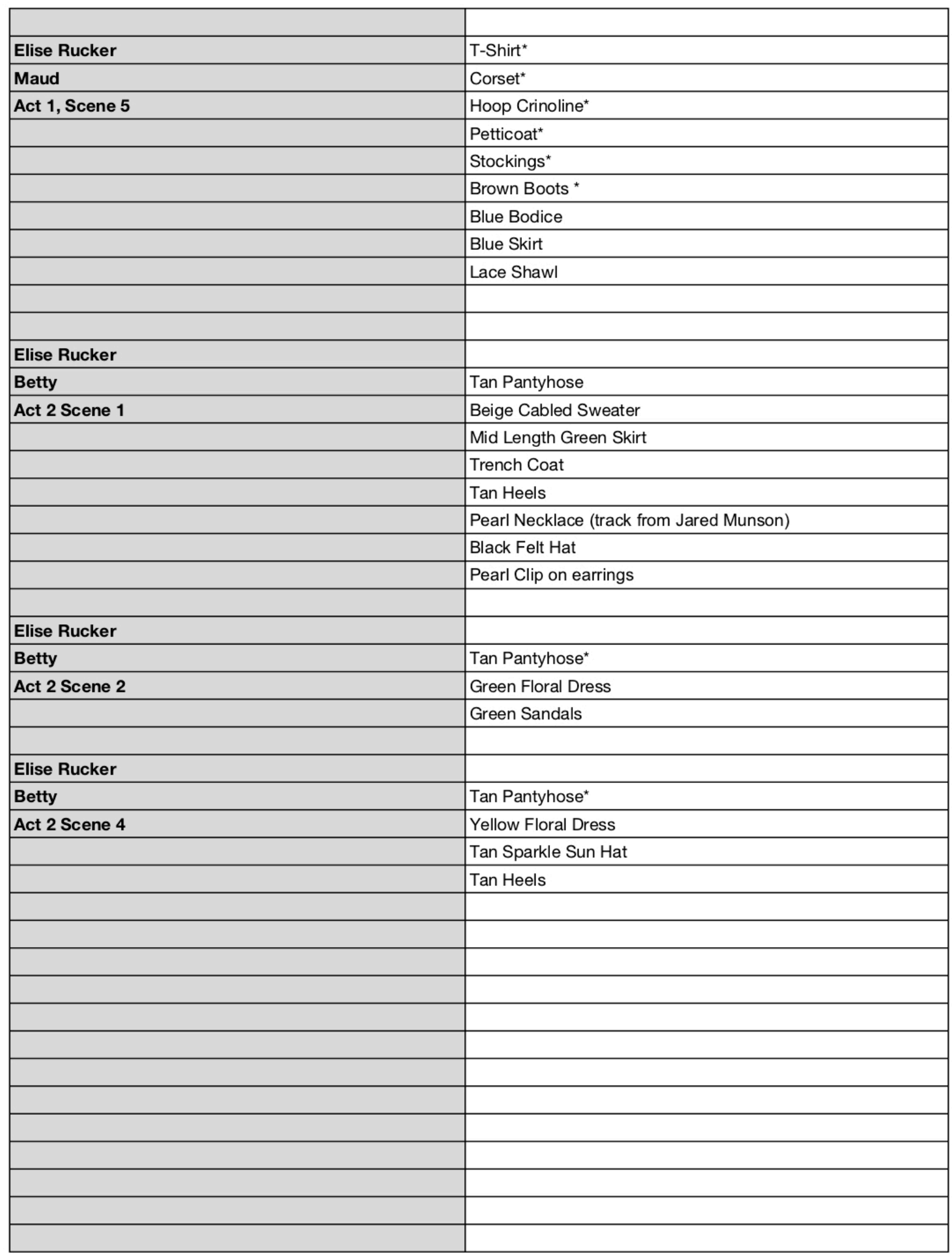




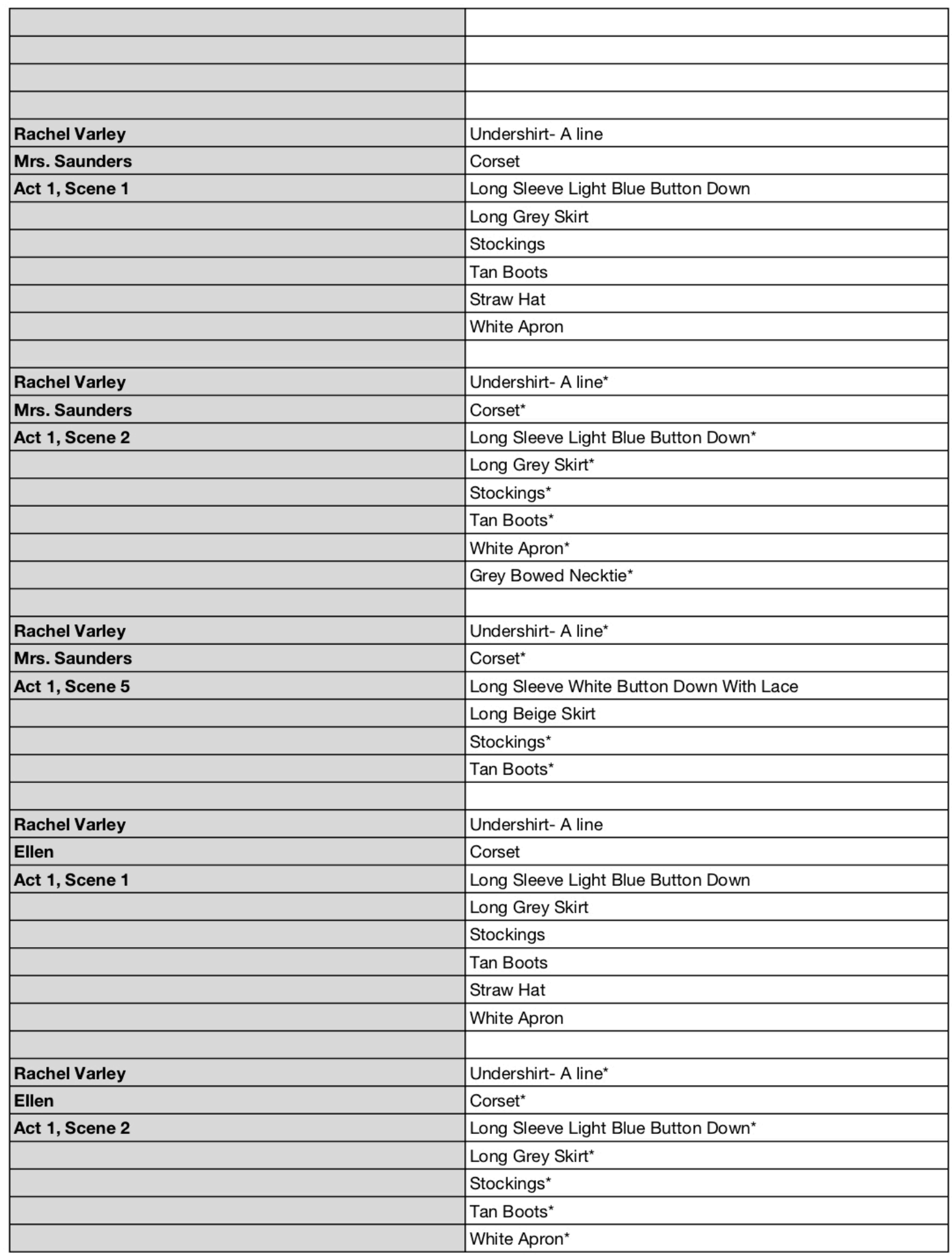




\begin{tabular}{|c|c|}
\hline Rachel Varley & Undershirt- A line ${ }^{\star}$ \\
\hline Ellen & Corset $^{*}$ \\
\hline \multirow[t]{4}{*}{ Act 1 , Scene 3} & Long Sleeve Light Blue Striped Button Down Shirt \\
\hline & Long Grey Skirt ${ }^{\star}$ \\
\hline & Stockings $^{*}$ \\
\hline & Tan Boots* \\
\hline Rachel Varley & Undershirt- A line ${ }^{\star}$ \\
\hline Ellen & Corset $^{\star}$ \\
\hline \multirow[t]{4}{*}{ Act 1 , Scene 4} & Long Sleeve Light Blue Striped Button Down Shirt* \\
\hline & Long Grey Skirt* \\
\hline & Stockings $^{\star}$ \\
\hline & Tan Boots* \\
\hline Rachel Varley & Undershirt- A line ${ }^{\star}$ \\
\hline Ellen & Corset $^{\star}$ \\
\hline \multirow[t]{6}{*}{ Act 1 , Scene 5} & Long Sleeve White Button Down With Lace \\
\hline & Long Beige Skirt \\
\hline & White Lace Neck Ruffle \\
\hline & Stockings ${ }^{*}$ \\
\hline & Tan Boots* \\
\hline & Long Veil with flower headdress \\
\hline \multicolumn{2}{|l|}{ Rachel Varley } \\
\hline Lin & Socks \\
\hline \multirow[t]{6}{*}{ Act 2 Scene 1} & As Above As Below Long Sleeve Shirt \\
\hline & Black Jeans \\
\hline & Black Boots \\
\hline & Black and Red Jacket \\
\hline & Knit Slouchy Hat \\
\hline & Loose Infinity Scarf \\
\hline \multicolumn{2}{|l|}{ Rachel Varley } \\
\hline Lin & Priestess T-Shirt \\
\hline \multirow[t]{2}{*}{ Act 2 Scene 2} & Black Overall Shorts \\
\hline & Short Tennis Shoes \\
\hline \multicolumn{2}{|l|}{ Rachel Varley } \\
\hline Lin & Full Moon T-Shirt \\
\hline \multirow[t]{3}{*}{ Act 2 Scene 3} & Denim Shorts with sequins \\
\hline & Black Socks \\
\hline & Black Belted Boots \\
\hline
\end{tabular}




\begin{tabular}{|l|l|}
\hline & \\
\hline Rachel Varley & \\
\hline Lin & \\
\hline Act 2 Scene 4 & Fish Riding a Bicycle Shirt \\
\hline & Black Jean Shorts \\
\hline & Olive Jean Vest \\
\hline & Short Tennis Shoes \\
\hline
\end{tabular}




\section{Appendix E: "Intermission Costume Change"}

This is the List of What each actor will take off and put on during the scene transition between Act 1 and Act 2 .

\section{Elise Rucker}

During Intermission Elise will Remove her Act 1 Bodice and Skirt, all her petticoats, and boots. She will Add her Act Two skirt and shoes leaving her in a skirt and corset.

During the Scene she will put on her grey trench coat from the Pile of Clothes.

\section{Jared Munson}

During Intermission Jared will remove his bodice and dress leaving on his fake boobs and petticoat.

During the Scene he will add his Act Two Grey T-Shirt.

\section{Ryan Ernst}

During Intermission Ryan will Remove his vest and change his suspenders. He will keep on his Act One Jacket.

During the Scene he will Add his Act Two glasses.

\section{Liam Holton}

During Intermission Liam will Remove his Jacket, Top Hat, and Vest.

During the Scene he will Add his Act Two Floral Jacket. 


\section{Matt Clark}

During Intermission Matt will change completely into Cathy without his hat/wig combination and rainbow jacket.

During the Scene Transition he will add the Rainbow Jacket.

\section{Haley Hizer}

During Intermission Haley will completely change into Victoria except for her wig and fur Jacket.

During the Scene she will add the fur jacket from the pile, she will change her wig after the scene transition before act two starts if there is time.

\section{Rachel Varley}

Rachel will completely change into Lin Act Two costume without her jacket, hat, and scarf.

During the Scene she will add the jacket from the pile, she will change her wig after the scene transition before act two starts if there is time.

She will also add her infinity scarf and knit hat. 